\title{
HYDROGEOLOGY OF, AND GROUND-WATER FLOW IN, A VALLEY-FILL AND CARBONATE-ROCK AQUIFER SYSTEM NEAR LONG VALLEY IN THE NEW JERSEY HIGHLANDS
}

by R.S. Nicholson, S.D. McAuley, J.L. Barringer, and A.D. Gordon

U.S. GEOLOGICAL SURVEY

Water-Resources Investigations Report 93-4157

Prepared in cooperation with the NEW JERSEY DEPARTMENT OF ENVIRONMENTAL PROTECTION

West Trenton, New Jersey 


\section{U.S. DEPARTMENT OF THE INTERIOR \\ BRUCE BABBIT,, Secretary}

U.S. GEOLOGICAL SURVEY

Gordon P. Eaton, Director

For additional information write to:

District Chief U.S. Geological Survey Mountain View Office Park

810 Bear Tavern Road, Suite 206

West Trenton, NJ 08628
Copies of this report can be purchased from:

U.S. Geological Survey

Earth Science Information Center

Open-File Reports Section

Box 25286, MS 517

Denver Federal Center

Denver, CO 80225 


\section{CONTENTS}

Abstract.

Introduction

Purpose and scope

Use of simulation in hydrogeologic analysis

Description of the study area

Previous numerical-modeling investigations of the study area

Scope of data collection.

Well-numbering system.

Acknowledgments.

Hydrogeology

Hydrogeologic framework

Model representation of hydrogeologic units

Valley-fill aquifer system

Upper valley-fill aquifer.

Upper valley-fill confining unit

Lower valley-fill aquifer.

Lower valley-fill confining unit

Paleozoic rock units

Paleozoic confining unit

Carbonate-rock aquifer

Other rock units

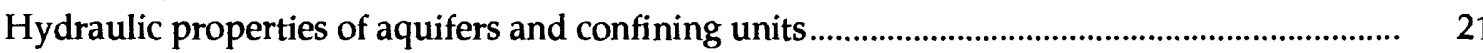

Upper valley-fill aquifer.

Upper valley-fill confining unit.

Lower valley-fill aquifer.

Composite Paleozoic-rock and lower valley-fill confining unit

Carbonate-rock aquifer

Other rock units

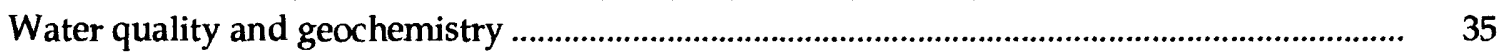

Quality of ground water in the study area ............................................................. $\quad 38$

Valley-fill aquifers.................................................................................................. 40

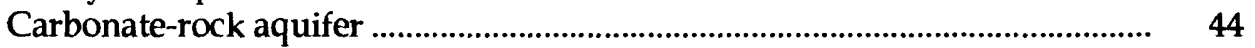

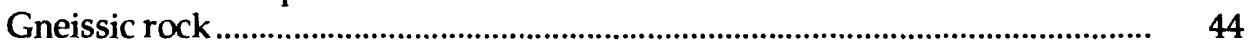

Conglomerate rock........................................................................................ 45

Quality of water in the streams of the study area ........................................................... 45

Age of ground water in the study area ......................................................................... $\quad 46$

Geochemical relations between water chemistry and lithology ................................. $\quad 48$

Interpretation of the calcium to magnesium ratio of ground water................ 48

Interpretation of the strontium-isotope ratio of ground water ......................... 50

Interpretation of dissolved-oxygen concentrations in ground water ............. 51

Ground-water flow

Effects of land use on water quality ................................................................................ 51

Conceptual model

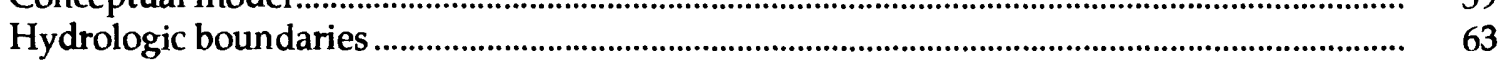

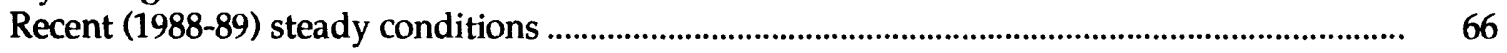

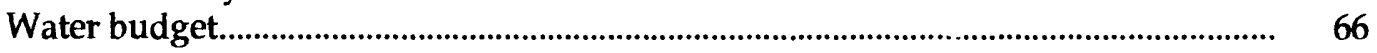

Systemwide water budget .................................................................................. 66

Distribution of flow within the system................................................................. 74

Ground-water levels and flow directions .................................................................... $\quad 80$ 


\section{CONTENTS}

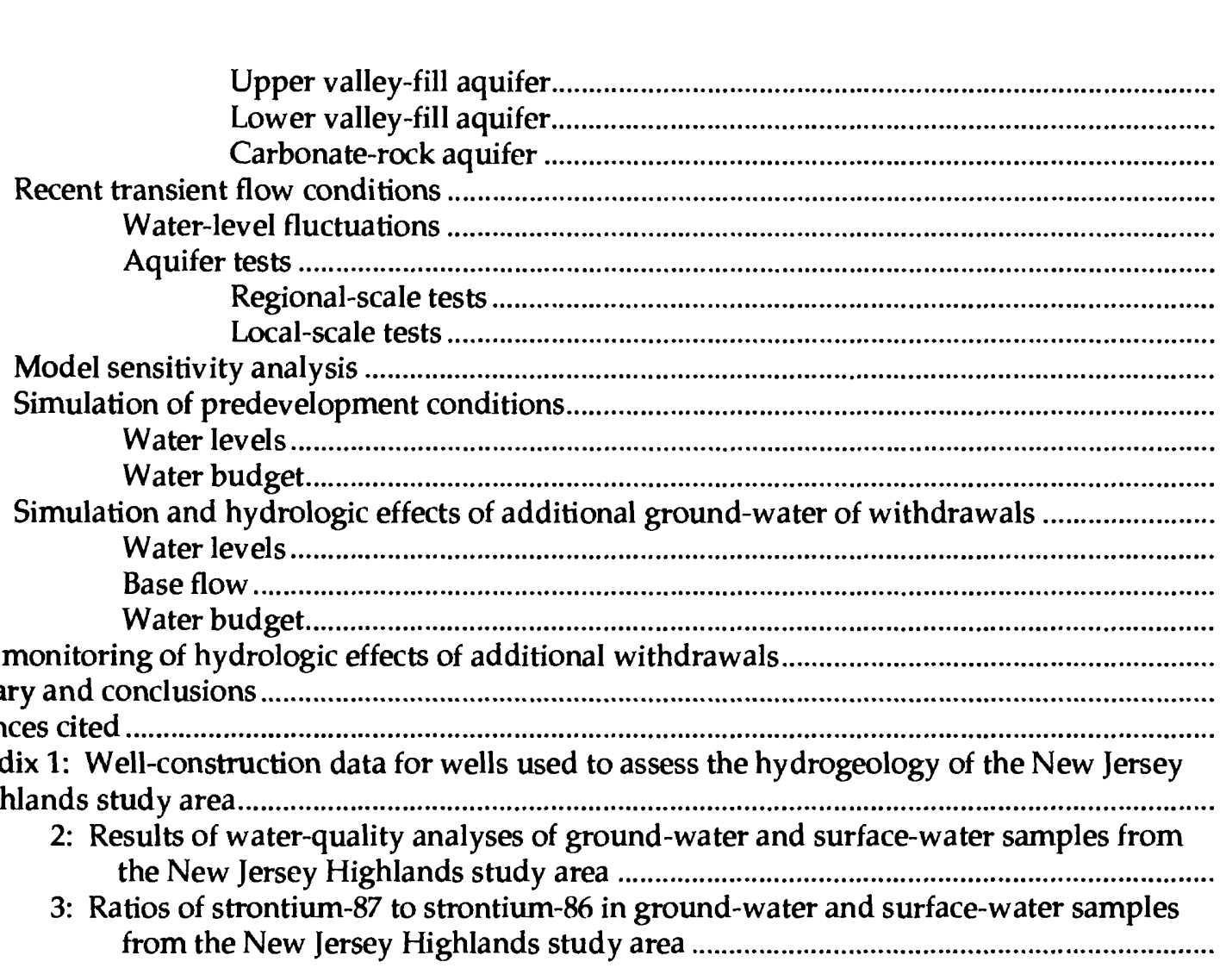

Future monitoring of hydrologic effects of additional withdrawals..................................................... 117

Summary and conclusions .................................................................................................................. 120

References cited

Appendix 1: Well-construction data for wells used to assess the hydrogeology of the New Jersey

Highlands study area.

\section{ILLUSTRATIONS}

\section{(Plates follow text in case)}

Plate 1a. Map showing locations of wells and springs used to assess the hydrogeology of the study area in the New Jersey Highlands

1b. Map showing model-grid extent, traces of generalized hydrogeologic sections, and boundaries used in simulations of ground-water flow

1c-f. Generalized hydrogeologic sections:
1c. $A-A^{\prime}$
1d. $B$ - $B^{\prime}$
1e. $C-C^{\prime}$
1f. D - D'

2a-3b. Maps showing:

2a. Observed average water-table surface of and generalized directions of ground-water flow in the upper valley-fill aquifer, 1988-89

2b. Simulated average water-table surface of the upper valley-fill aquifer, 1988-89, and differences between simulated and observed water levels

2c. Observed average potentiometric surface of and generalized directions of ground-water flow in the lower valley-fill aquifer, 1988-89

$2 d$. Simulated average potentiometric surface of the lower valley-fill aquifer, 1988-89, and differences between simulated and observed water levels

3a. Observed average potentiometric surface of and generalized directions of ground-water flow in the carbonate-rock aquifer, 1988-89

3b. Simulated average potentiometric surface of the carbonate-rock aquifer, 1988-89, and differences between simulated and observed water levels 


\section{ILLUSTRATIONS--Continued}

Page

Figure 1-9. Maps showing:

1. Location of the study area in the New Jersey Highlands ............................................ 3

2. Generalized surficial geology of the study area.............................................................. 7

3. Generalized bedrock geology of the study area ............................................................ 9

4. Discretized thickness of the upper valley- fill aquifer.................................................. 11

5. Discretized thickness of the lower valley-fill aquifer ................................................ $\quad 12$

6. Discretized thickness of the upper confining unit ....................................................... 13

7. Discretized thickness of the lower confining unit....................................................... 14

8. Discretized thickness of the Paleozoic confining unit................................................ 15

9. Discretized thickness of the carbonate-rock aquifer........................................................ 16

10. Diagram showing schematic representation of aquifers, confining units, and boundary conditions in the numerical flow model of the aquifer system near Long Valley in the New Jersey Highlands...

11-15. Maps showing:

11. Location of aquifer-test sites in the study area.

12. Extent of the upper valley-fill aquifer and distribution of horizontal hydraulic conductivity, as represented in the model

13. Distribution of vertical leakance between the upper valley-fill aquifer and underlying aquifers, as represented in the model

14. Extent of the lower valley-fill aquifer and distribution of horizontal hydraulic conductivity, as represented in the model ...

15. Distribution of vertical leakance between valley-fill aquifers and the carbonate-rock aquifer, as represented in the model.

16. Graph showing distribution of water-bearing zones with depth in the carbonate-rock aquifer in the New Jersey Highlands near Long Valley.

17. Map showing specific capacity per unit length of open borehole of wells open to the carbonate-rock aquifer.

18. Map showing extent of carbonate-rock aquifer and distribution of downvalley horizontal hydraulic conductivity, as represented in the model

19. Map showing streamflow-measurement and surface-water-quality sampling sites

20. Selected Stiff diagrams for water from the valley-fill aquifers, the carbonate-rock aquifer, and the gneissic rock in the New Jersey Highlands study area.

\section{.}

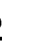
(1) 16 . 


\section{ILLUSTRATIONS--Continued}

23-35. Maps showing-Continued:

30. Generalized directions of ground-water-flow in the upper valley-fill aquifer

31. Generalized directions of ground-water-flow in the lower valley-fill aquifer, and areas where the aquifer is unconfined.

32. Generalized directions of ground-water-flow in the carbonate-rock aquifer, and areas where the aquifer is unconfined....

33. Generalized ground-water flow directions in the New Jersey Highlands study area

34. Streambed and lakebed conductance used in the model.

35. Locations of rain-gaging stations and graph showing monthly precipitation for the period 1985-90

36. Graph showing monthly pumpage from the aquifer system near Long Valley in the New Jersey Highlands, 1985-90.

37. Average pumpage from the aquifer system, April 1989.

38. Map showing stream reaches with simulated gains or losses of flow from or to the aquifer system, and locations of stream reaches for which simulated base-flow gains were compared with measured gains

39. Diagram showing simulated water budget under recent (1988-89) steady conditions for the aquifer system near Long Valley in the New Jersey Highlands.

40. Hydrographs showing relation between mean water level during recent period and water levels during synoptic surveys of the aquifer system near Long Valley in the New Jersey Highlands.

41. Map showing simulated direction of flow across the bottom of the upper valley-fill aquifer under recent, steady conditions

42. Map showing simulated direction of flow across the bottom of the lower valley-fill aquifer under recent, steady conditions

43-47. Graphs showing:

43. Hydrographs showing water levels in wells $27-1125$ and 27-1191, and pumpage from wells 27-1090 and 27-1324, November-December 1989, New Jersey Highlands study area.

44. Hydrographs showing water levels in wells 27-1123 and 27-1125, March 1989February 1991, and pumpage from well 27-1090, January 1989-February 1991, New Jersey Highlands study area...

45. Hydrographs showing water levels measured monthly in carbonate-rock aquifer wells 19-0299, 27-1106, 27-1155, and 27-1099, 1988-1990, New Jersey Highlands study area.

46. Hydrographs showing water levels measured monthly in wells 27-1121, 27-1712, 27-1098, and 27-921, 1988-90, New Jersey Highlands study area

47. Logarithmic plots of drawdown observed over time in six observation wells open to the carbonate-rock aquifer, observed during the Morris County Municipal Utilities Authority (A) FL1 and (B) FL2 aquifer tests at Flanders, New Jersey, September 1990 and August 1990.

48. Logarithmic plots of observed and simulated drawdown over time in six observation wells open to the carbonate-rock aquifer, Morris County Utilities Authority FL1 aquifer test at Flanders, New Jersey, September 1990.

49. Map showing observed and simulated draw down in the carbonate-rock aquifer after 3 days of pumping, Morris County Municipal Utilities Authority FL1 aquifer test at Flanders, New Jersey, September 1990

50. Semilogarithmic plot of drawdown over time in observation well 27-1322 during the Roxbury Water Company 1-A aquifer test at Succasunna, New Jersey, January 1990

51. Semilogarithmic plot of recovery over time in well 27-1126 during the USGS Black River 4 aquifer test near Chester, New Jersey, April 1990 


\section{ILLUSTRATIONS--Continued}

Page

52-62. Maps showing:

52. Simulated change in average water levels in the upper valley-fill aquifer from predevelopment conditions that resulted from recent ground-water withdrawals

53. Simulated change in average water levels in the lower valley-fill aquifer from predevelopment conditions that resulted from recent ground-water withdrawals

54. Simulated change in average water levels in the carbonate-rock aquifer from predevelopment conditions that resulted from recent ground-water withdrawals

55. Simulated water budgets for the New Jersey Highlands aquifer system near Long Valley under predevelopment and recent average conditions

56. Locations of the Morris County Municipal Utilities Authority Alamatong well field; the hypothetical well field at Flanders, New Jersey; and the model cells used to simulate withdrawals from the well fields..

57. Simulated change in average water levels in the carbonate-rock aquifer resulting from an additional withdrawal of 5.7 million gallons per day from a hypothetical well field tapping the carbonate-rock aquifer

58. Simulated change in average water levels in the carbonate-rock aquifer resulting from an additional withdrawal of 4.8 million gallons per day from a hypothetical well field tapping the carbonate-rock aquifer and a decrease in withdrawals of 1.3 million gallons per day from the Alamatong well field

59. Simulated change in average water levels in the lower valley-fill aquifer resulting from an additional withdrawal of 5.7 million gallons per day from a hypothetical well field tapping the carbonate- rock aquifer.

60. Simulated change in average water levels in the lower valley-fill aquifer resulting from an additional withdrawal of 4.8 million gallons per day from a hypothetical well field tapping the carbonate- rock aquifer and a decrease in withdrawals of 1.3 million gallons per day from the Alamatong well field

61. Location of greatest simulated base-flow reduction resulting from an additional withdrawal of 5.7 million gallons per day from a hypothetical well field tapping the carbonate-rock aquifer.

62. Part of the South Branch Raritan River Basin included in the analysis of simulated ground-water budgets under various flow conditions...

63. Diagram showing simulated ground-water budgets for the South Branch Raritan

River Basin under recent average conditions and under conditions simulated in Scenarios A and B.

\section{TABLES}

Table 1. Hydrogeologic characteristics of water-yielding units in the study area

2. Summary of hydraulic characteristics determined from aquifer tests in the study area .

3. Hydraulic-conductivity values estimated from specific-capacity data for selected wells in the lower valley-fill aquifer.

4. Statistical summary of selected chemical characteristics of and constituents in water samples from the valley-fill aquifers, carbonate-rock aquifer, and gneissic rock ...........

5. Volatile organic compounds found in ground-water samples from the study area near Long Valley in concentrations greater than the minimum reporting limits. 


\section{TABLES--Continued}

Table 6. Estimated recent (1988) average flow gains at locations where streams leave the study area

7. Production wells withdrawing water from study-area aquifers in April 1989

8. Average base flow and results of low-flow-correlation analysis for 21 partial-record measurement sites in the study area

9. Base-flow-gain determinations and simulated base-flow gains for eight stream reaches.

10. Summary of simulated alternative water-supply scenarios............................................... 107

11. Predicted changes in pumping water levels of six public supply wells.

12. Simulated base-flow changes, characteristic low flows, and statutory minimum passing flows at four streamflow-measurement locations 


\section{CONVERSION FACTORS, VERTICAL DATUM, AND ABBREVIATIONS}

\section{Multiply}

By

To obtain

Length

inch (in.)

2.540

foot $(\mathrm{ft})$

0.3048

1.609

centimeter

mile (mi)

Area

acre

0.004047

square kilometer

square foot $\left(\mathrm{ft}^{2}\right)$

0.09290

square meter

square mile $\left(\mathrm{mi}^{2}\right)$

2.590

square kilometer

Flow

cubic foot per second $\left(\mathrm{ft}^{3} / \mathrm{s}\right)$

0.02832

cubic meter per second

gallon per minute (gal/min)

0.06308

0.04381

meter

million gallons per day (Mgal/d)

0.04381

liter per second

million gallons per month (Mgal/mo)

Hydraulic conductivity and transmissivity

foot per day (ft/d)

foot squared per day $\left(\mathrm{ft}^{2} / \mathrm{d}\right)$

0.3048

0.09290

Specific capacity gallon per minute per

foot $[(\mathrm{gal} / \mathrm{min}) / \mathrm{ft}]$

0.2070

\section{Water quality}

tritium unit (pCi/L) meter per day meter squared per day cubic meter per second
cubic meter per month

Sea level: In this report "sea level" refers to the National Geodetic Vertical Datum of 1929--a geodetic datum derived from a general adjustment of the first-order level nets of both the United States and Canada, formerly called Sea Level Datum of 1929.

Abbreviations:

$\mu \mathrm{g} / \mathrm{L}=$ micrograms per liter

$\mathrm{mg} / \mathrm{L}=$ milligrams per liter

$\mu \mathrm{S} / \mathrm{cm}=$ microsiemens per centimeter at 25 degrees Celsius

$\mathrm{pCi} / \mathrm{L}=$ picocuries per liter

$\mathrm{TU}=$ tritium unit

$\mathrm{Mgal}=$ millions of gallons 



\title{
HYDROGEOLOGY OF, AND GROUND-WATER FLOW IN, A VALLEY-FILL AND CARBONATE-ROCK AQUIFER SYSTEM NEAR LONG VALLEY IN THE NEW JERSEY HIGHLANDS
}

\author{
by R.S. Nicholson, S.D. McAuley, J.L. Barringer, and A.D. Gordon
}

\begin{abstract}
The valley-fill and carbonate-rock aquifer system near Long Valley is an important source of ground water in southwestern Morris and northeastern Hunterdon Counties, where demand for water is increasing. Through this study, the hydrogeology of the area was assessed, and numerical-modeling techniques were used to evaluate the ground-water-flow system and the factors that limit water-supply availability.

The effects of recent and anticipated withdrawals on stream base flows, water levels, and the overall water budget were estimated. Simulation results indicate that recent withdrawals have resulted in water-level declines of up to 35 feet near pumping centers. Under conditions of projected increases in ground-water withdrawals of 121 percent, average water levels in the carbonate-rock aquifer would decline up to 28 feet, but water levels in two public supply wells in the affected area during pumping would not approach the depths of present pump intakes. The magnitude of predicted average base-flow depletion, when compared with historic low flows, indicates that projected increases in pumpage may substantially deplete seasonal low flow of Drakes Brook and the South Branch Raritan River. Average base flow of Drakes Brook at Bartley would decrease from 20.5 cubic feet per second by as much as 5.3 cubic feet per second, or 26 percent. Historically, low flows at this location have been less than 5.3 cubic feet per second.

Water-budget changes that would result from increased withdrawals from the carbonate-rock aquifer include (1) decreased discharge to rivers from the aquifer system, (2) increased downward flow from and decreased upward flow to the lower valley-fill aquifer, (3) increased lateral flow of ground water into the South Branch Raritan River Basin from the Lamington River Basin, and (4) a slight increase in tributary-stream leakage to the aquifer system. These water-budget changes are indicative of the sources of water to additional supply wells.

Water-quality data indicate that human activities are affecting ground water, particularly in the northern and central parts of the study area. With the exception of an elevated iron concentration in water from one well, concentrations of inorganic constituents in water from 75 wells sampled did not exceed New Jersey primary or secondary drinking-water regulations. Volatile organic compounds were detected in water from several wells; in two samples, concentrations of specific compounds exceeded drinking-water regulations. A data-collection program designed for early detection of potential adverse effects of watersupply development would include (1) continuous gaging of streamflow in the South Branch Raritan River near Naughright, (2) frequent measurement of water levels in nests of wells open to each aquifer, and (3) water-quality sampling in nests of wells open to each aquifer.
\end{abstract}

\section{INTRODUCTION}

A valley-fill and carbonate-rock aquifer system in the New Jersey Highlands, extending from Califon in the south to Picatinny Arsenal in the north, is an important source of ground water in a region that is experiencing increasing demand for water. The aquifer system and adjacent upland areas cover an 
area of about $98 \mathrm{mi}^{2}$ (fig. 1). Aquifers within the valley-fill sediments supply water to Picatinny Arsenal and the communities of Succasunna and Kenvil. The carbonate-rock aquifer supplies water to communities from Califon to Kenvil, inclusive.

Prior to the study reported here, the hydrogeology of some parts of the area had been investigated, but the regional flow system, particularly the interactions between the aquifers and the interactions between the aquifers and surface waters, had not been evaluated. On the basis of historical well yields and water-level drawdowns, the potential for additional ground-water development is substantial. Wells tapping the confined valley-fill aquifer and wells tapping the carbonate-rock aquifer have produced yields of up to 1,700 and $2,000 \mathrm{gal} / \mathrm{min}$, respectively. Total withdrawals from the aquifers averaged about $5 \mathrm{Mgal} / \mathrm{d}$ in 1989 and were increasing in response to residential and commercial growth. In order to meet increasing water-supply needs, planning agencies have recommended that new well fields be developed to yield large volumes of potable water (Killam Associates, Inc., 1982, p. 6-15). This growth has resulted in concern about the adequacy of the aquifers in the area to meet the increasing demand for water and about hydrogeologic issues such as streamflow reduction, well-field interference, and contaminant migration. Although stream depletion and well-field interference are not known to be problems at present, several public supply and domestic wells tapping valley-fill sediments have become unusable recently as a result of organic contamination. Effective water-resources planning and management, which minimize the potential for these problems, require the definition of the regional hydrogeologic framework and flow system and an understanding of the operation of the flow system and its response to withdrawal stress. During 1987-90, the U.S. Geological Survey (USGS) in cooperation with the New Jersey Department of Environmental Protection, conducted a hydrogeologic study to obtain information and conduct analyses that would address these concerns to facilitate effective water-resources planning and management.

\section{Purpose and Scope}

This report describes the hydrogeology of the valley-fill and carbonate-rock aquifer system near Long Valley in the New Jersey Highlands and presents the results of a numerical ground-water-flow modeling analysis. Specific effects of pumpage that potentially could limit the availability of ground water for water supply, such as stream base-flow depletion, well- field interference, and vulnerability to contamination (McAuley and others, 1992, p. 12), are addressed.

The hydrologic assessment includes the interpretation of data on the hydrogeologic framework, aquifer and confining-unit characteristics, water levels, ground-water withdrawals, stream discharge, and water quality. Most of the hydrogeologic-framework information is based on work done by the New Jersey Geological Survey (NJGS) (L. J. Nicholson, New Jersey Geological Survey, written commun., 1990; Robert Canace, New Jersey Geological Survey, written commun., 1990). Interpretations of the water quality and geochemistry of the aquifer system include a discussion on the effects of land use on water quality.

A conceptual model of the ground-water system is presented, and the mathematical representation of the aquifer system used to simulate ground- water flow is described. Throughout the report, results of ground-water-flow simulations are presented together with qualitative interpretations of hydrogeologic data. Numerical modeling techniques were used for the following analyses: (1) a steady-state analysis of recent (1988-89) conditions to estimate water-transmitting properties of aquifers and confining units, to test and refine concepts of flow and boundary conditions, and to determine the water budget; (2) a transient analysis of flow conditions during aquifer tests, in which water-transmitting properties and boundary conditions were tested further and refined; (3) an evaluation of conditions that prevailed prior to large groundwater withdrawals from the aquifer system; and (4) an evaluation of the simulated hydrologic effects of additional ground-water withdrawal from the carbonate-rock aquifer. Simulated hydrologic effects include base-flow depletion, water- level declines, and increased flow between aquifers. 


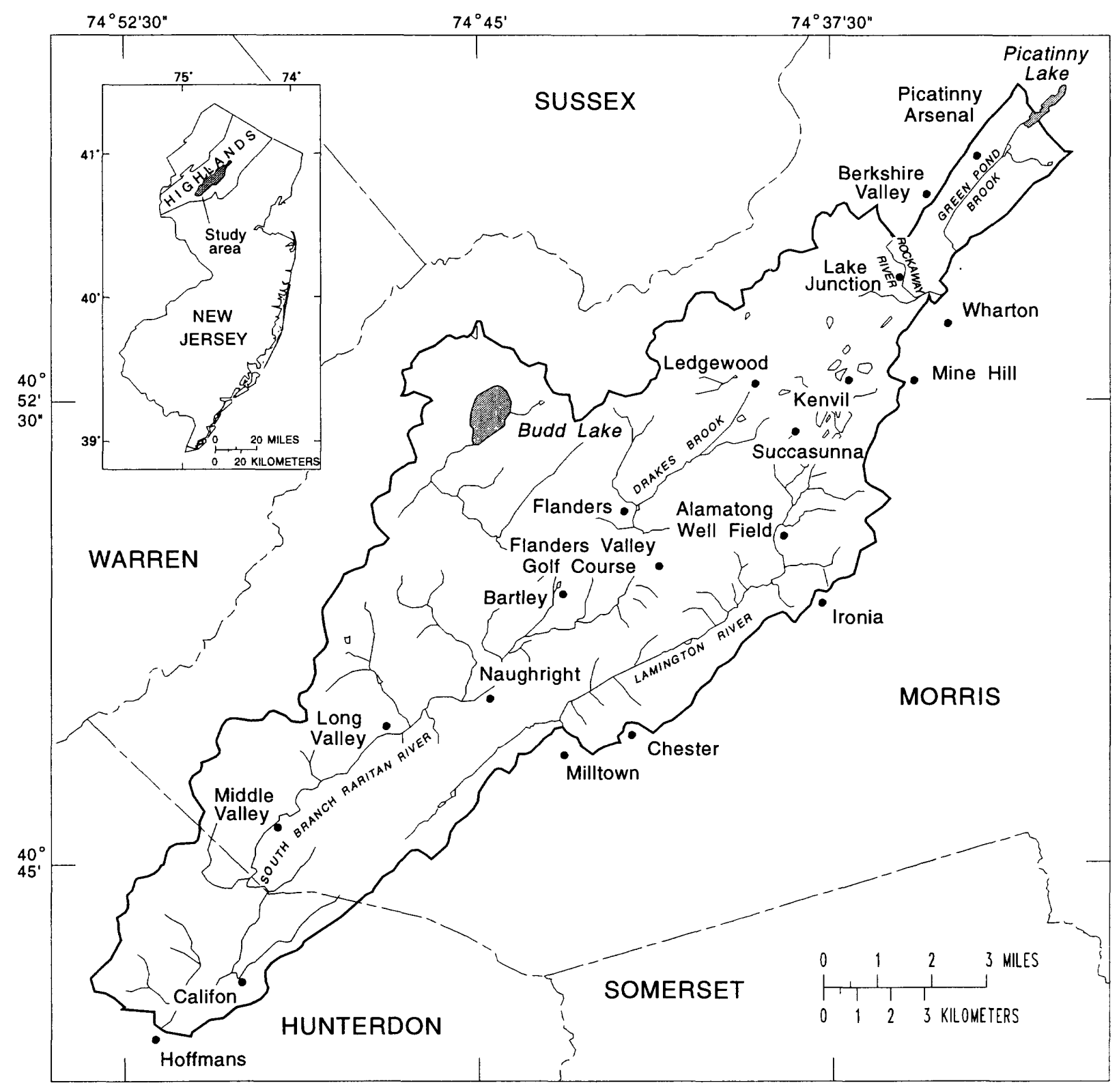

Figure 1. Location of the study area in the New Jersey Highlands. 


\section{Use of Simulation in Hydrogeologic Analysis}

The numerical model developed for the purpose of analyzing the flow system is a simplified mathematical representation of the physical system. The model consists of a series of equations governing the flow of ground water in a discretized (gridded) representation of the system. The equations are solved simultaneously for head and flow at discrete points within the system.

During the modeling process, concepts of flow are tested, water- transmitting properties are estimated, and various flow conditions are evaluated. Throughout this process, the model representations of hydrogeologic geometries, water-transmitting properties, flow-system boundaries, and imposed stresses reflect and integrate the concepts of the ground-water-flow system.

Model output is the simulated distribution of hydraulic head and flow. This output is compared with observed data in order to evaluate the accuracy of the conceptual model and values of hydrogeologic properties. During calibration, the model is refined until simulated results are reasonably consistent with observed data, at which point the model is considered to represent the ground-water-flow system accurately. The degree to which the model accurately simulates historical conditions indicates the degree to which the model is expected to simulate accurately the effects of projected increases in ground-water withdrawals on the ground-water-flow system. Model output from simulations of specific hydrologic conditions provides insight into the operation of the ground-water system and its response to increased withdrawals for water-supply.

\section{Description of the Study Area}

The study area encompasses about 98 square miles in Morris and Hunterdon Counties in the central part of the New Jersey Highlands. It includes parts of the drainage areas of three major rivers: the Lamington River, the South Branch Raritan River, and the Rockaway River (fig. 1). In the Lamington River drainage area, the study area extends from the headwaters north of Kenvil to above Milltown. In the South Branch Raritan River drainage basin, the study area extends from the headwaters near Budd Lake to Hoffmans, 2 miles southwest of Califon. The entire extent of the Drakes Brook drainage basin, a principal tributary to South Branch Raritan River, is included in the study area. In the Rockaway River drainage basin, the study area extends from 2 miles northwest of Wharton to just above Wharton. Most of the drainage basin of Green Pond Brook, from Picatinny Lake in the northern part of Picatinny Arsenal to above Wharton, are included. The valleys within these drainage areas, where valley-fill deposits and carbonate rocks of the Leithsville Formation and Allentown Dolomite are present (Lyttle and Epstein, 1987; Volkert and others, 1990a and 1990b), comprise the principal area of study; however, the upland areas are included in order to study the hydrologic interaction between uplands and valleys. The valleys are rolling and flat, and are bounded by steep-sided valley walls that have relatively narrow ridgetops. The hillslopes and ridgetops constitute the uplands and are underlain by crystalline rocks and conglomerate. The valleys and ridges trend northeast-southwest; relief between valleys and ridgetops generally is about 500 feet.

\section{Previous Numerical-Modeling lnvestiagtions of the Study Area}

Several numerical modeling investigations have been conducted on the ground-water resources of parts of the study area. Voronin (1991) described the ground-water-flow system at Picatinny Arsenal as part of the ongoing investigation of ground-water contamination in that area. Voronin discusses groundwater flow in that system and the results of steady-state and transient-state simulations of ground-water flow under various recharge schemes. Picatinny Arsenal occupies the northernmost part of the present study area. Schaefer and others (1993) describe the ground-water and surface-water flow systems of the upper Rockaway River Basin, including an assessment of ground-water and surface-water quality, and the chemical quality of streambed material; A.D. Gordon (1995) describes a steady-state ground-water-flow model of the valley-fill aquifer system of the upper Rockaway River Basin. Gordon defines the ground- 
water-flow system and the effects of current and anticipated increases in ground-water withdrawals on the ground-water-flow system and on ground-water discharge to the Rockaway River. Hill (1985) investigated the hydraulic conductivity of the upper valley-fill aquifer by using trial-and-error and automated techniques to calibrate a numerical ground-water-flow model. The model was used to simulate the steady-state response of the upper valley-fill aquifer to withdrawals north of Kenvil. The focus of the investigation was a comparison of the two calibration techniques.

\section{Scope of Data Collection}

A variety of hydrogeologic data were collected over the course of this investigation and were used to determine hydraulic properties of aquifers and confining units, to document water levels and water use, and to evaluate water quality and geochemistry. Data from test-well drilling also were used in concurrent efforts by the NJGS to define the hydrogeologic framework over most of the study area. The following is a summary of the scope of data collection.

An onsite inventory of a representative sample of existing wells in the study area was conducted, resulting in the addition of information on 253 wells to the Ground Water Site Inventory (GWSI) data base of the USGS. This information includes drillers' logs and well-construction, water-level, and well-performance data. Fifteen test wells were drilled by the USGS and the NJGS at various locations in the study area to improve hydrogeologic control. The locations of all wells used in the analyses presented here are shown on plate 1a. Geophysical logs of test-well boreholes and several other wells were obtained, and lithologic samples of carbonate rock and overlying confining-unit material were obtained from one of the test-well boreholes. Surface geophysical surveys and geophysical borehole logging also were conducted by the NJGS.

Water levels were measured synoptically in many wells to define the water-table and potentiometric surfaces of the aquifers. Water levels also were measured monthly in 8 wells and continuously in 12 wells to document water-level fluctuations. Five aquifer tests were conducted by various parties during the investigation. Streamflow under low-flow conditions was measured at 10 sites on a quarterly basis. Reported water-use data for the period 1955-89 were collected and entered into the Site-Specific Water-Use Data System (SWUDS) of the USGS. Water-quality samples were collected at 75 ground-water sites and at 6 surface-water sites.

\section{Well-Numberina System}

The USGS well numbers used in this report are the numbers assigned to wells and springs in the GWSI data base of the USGS. Each well number consists of a two-digit county code followed by a four-digit sequence number. County codes used in this report are 19 (Hunterdon) and 27 (Morris). For example, well number 27-1089 was the 1,089th well or spring in Morris County to be entered into the GWSI data base.

\section{Acknowledaments}

The cooperation of well owners in providing access to wells for water samples, water-level measurements, and geophysical logging is gratefully acknowledged. Special thanks are extended to the Morris County Municipal Utilities Authority; the Mount Olive Township Water Department; the Roxbury Township Water Department; Washington Township Municipal Utilities Authority; Wharton Borough Water Department; the Black River Wildlife Management Area; the Roxbury Water Company; the Garden State Water Company; Drew University; Kenvil Newcrete Products, Incorporated; Hercules, Incorporated; Welsh Farms, Incorporated; and Simmonds Precision Cooperative Industries for providing data and access 
to their wells and properties. Additional thanks are given to Morris County Municipal Utilities Authority, Washington Township Municipal Utilities Authority, the Black River Wildlife Management Area, and the Roxbury Water Company for their cooperation and assistance during aquifer tests.

\section{HYDROGEOLOGY}

In the following sections, the hydrogeologic framework, hydraulic properties of aquifers and confining units, and quality and geochemistry of water in the study area are presented. The hydrogeologic framework is presented as it was represented in model simulations, in discretized form; aquifer and confining-unit thicknesses, determined as part of and modified from previous investigations, are presented in maps of contoured values of thickness. A summary of information on hydraulic characteristics for each hydrogeologic unit is presented, as well as maps of values used in simulations. Ambient quality of surface and ground water is summarized, and an evaluation of the age of ground water is presented. Geochemical relations, including the ratio of calcium to magnesium, the ratio of two different isotopes of strontium, and the relation between concentrations of dissolved oxygen and distance along flow paths, and the effects of land use on water quality, also are discussed.

\section{Hydrogeologic Framework}

A series of northeast-trending ridges and intervening valleys characterize the topography of the study area. The relief ranges from tens of feet in headwater areas to greater than 600 feet in areas deeply dissected by rivers. The valleys have been partly filled with unconsolidated alluvial, colluvial, and glacial deposits (fig. 2). In some areas, weathered bedrock residuum underlies valley-fill sediments. Together, these overburden sediments form two valley-fill aquifers and two confining units. The rocks underlying the valley-fill sediments are part of a generally infolded and upfaulted geosyncline extending 60 miles from Califon, New Jersey, to Cornwall, New York (Barnett, 1976), that formed as a result of tectonic activity associated with the formation of the Appalachian Mountains. These rocks include Paleozoic sandstones, shales, conglomerates, and carbonates, and Precambrian crystalline rocks (table 1). The Longwood Valley Fault (fig. 3) and several minor oblique faults or offshoots trend northeast through the study area. The permeability of the carbonate rocks has been enhanced significantly by extensive weathering, fracturing, and solution channeling.

The extents and thicknesses of the aquifers and confining units present in the study area were determined as part of several previous investigations. The geometries of the valley-fill units and bedrock units in the study area from the southwestern boundary of the study area to the southern end of Picatinny Arsenal are described by L.J. Nicholson (New Jersey Geological Survey, written commun., 1990) and Robert Canace (New Jersey Geological Survey, written commun., 1990), respectively. Three aquifers were identified--two valley-fill aquifers and one carbonate-rock aquifer--as had been speculated by Hill $(1985$, p. 142150); two intervening confining units also were identified. Voronin (1991) described 11 high- and low-permeability units at Picatinny Arsenal in a local-scale (contaminant plume) investigation. In the analyses presented in this report, three aquifers and two confining units are identified. This generalization of the framework at Picatinny Arsenal was considered appropriate given the scale and scope of the present study. Other sources of data used in determining and evaluating the framework were drillers' logs; geophysical logs; lithologic logs; and 1:24,000-scale, surficial- and bedrock-geology maps produced by means of the Cooperative Geologic Mapping (COGEOMAP) program conducted by the USGS, Geologic Division, and the NJGS. The COGEOMAP surficial-geology map used is the Dover quadrangle (Stanford, 1989), and the COGEOMAP bedrock-geology maps used are the Stanhope quadrangle (Volkert and others, 1989), the Chester quadrangle (Volkert and others, 1990a), and the Califon quadrangle (Volkert and others, 1990b).

The two valley-fill aquifers (an upper valley-fill aquifer and a lower valley-fill aquifer) are composed of Quaternary alluvial, glacial-outwash, and terminal-moraine sediments. A third aquifer consists of Cambrian dolomite rock. The two intervening confining units consist of Quaternary alluvium, lakebot- 


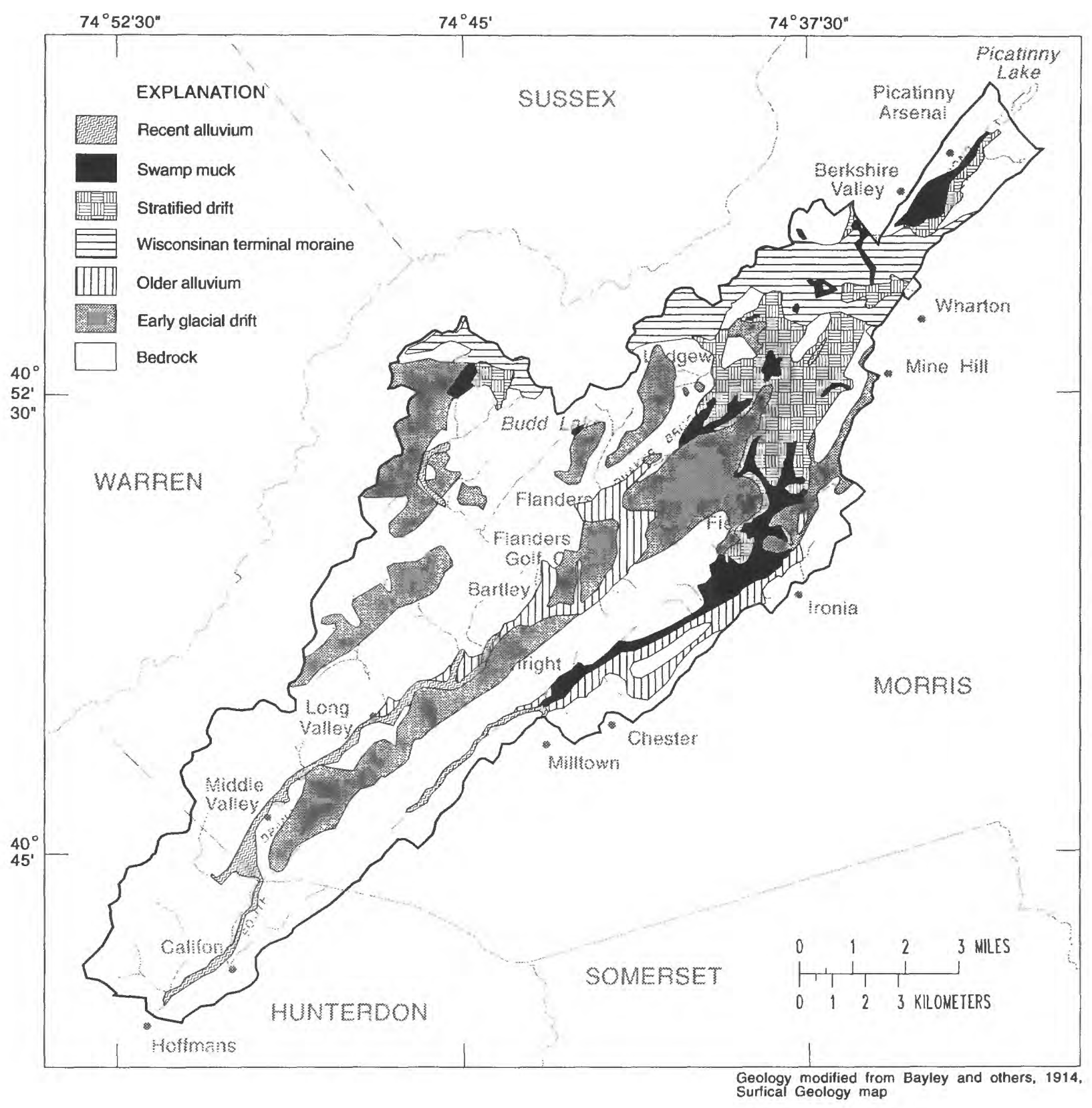

Figure 2. Generalized surficial geology of the study area. 
Table 1. Hydrogeologic characteristics of water-ylelding units in the study area

[Modified from Drake (1969, table 20); Sims (1958, plate 1); Gill and Vecchioli (1965, table 3); Lyttle and Epstein (1987, sheet 2; Herman and Mitchell (1991, plate 1); D.P. Harper (New Jersey Geological Survey, written commun., 1979); Robert Canace, J.P. Mitchell, G.C. Herman, and S.D. Stanford (New Jersey Geological Survey, written commun., 1988), and Volkert and others, 1990.]

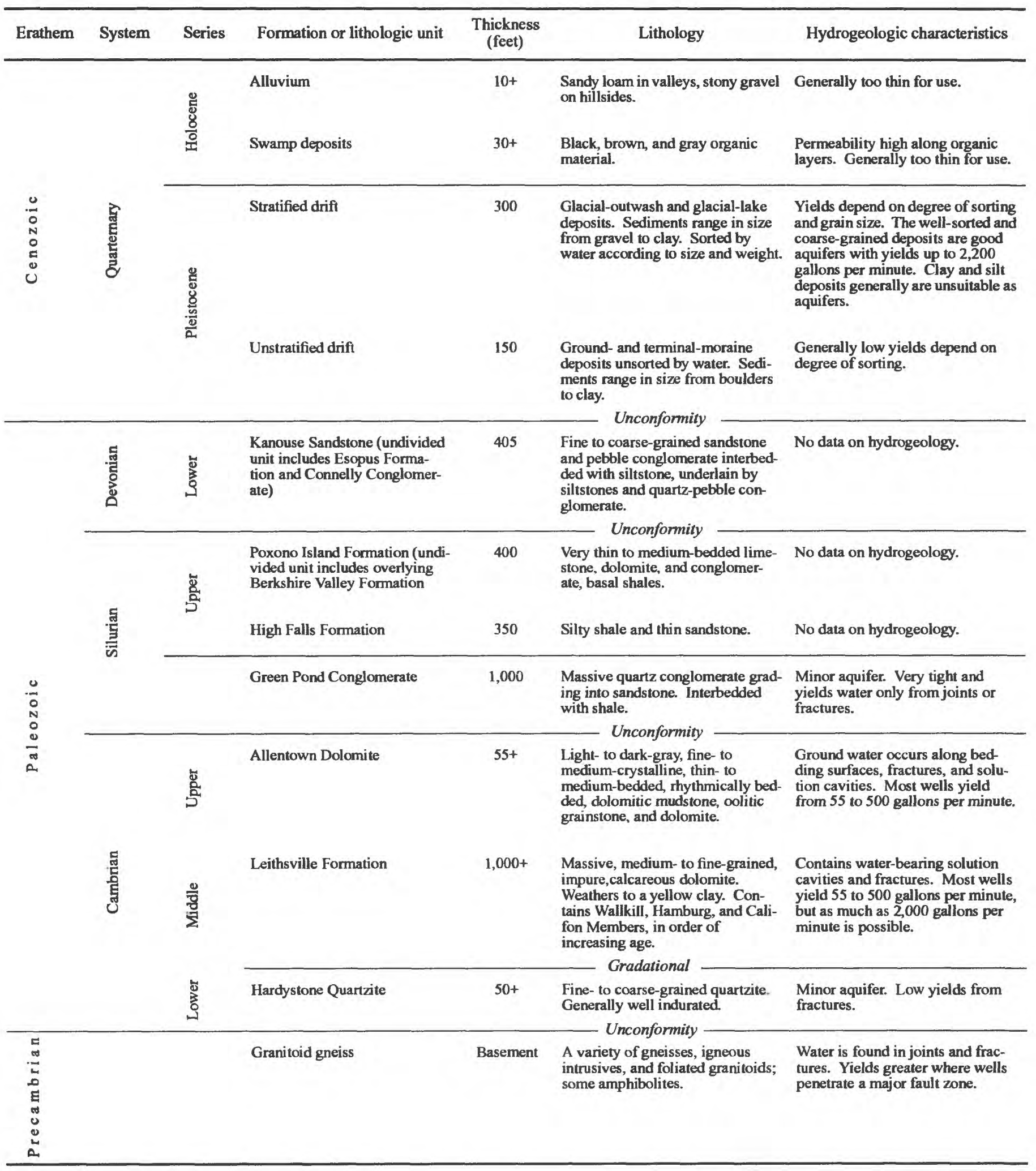




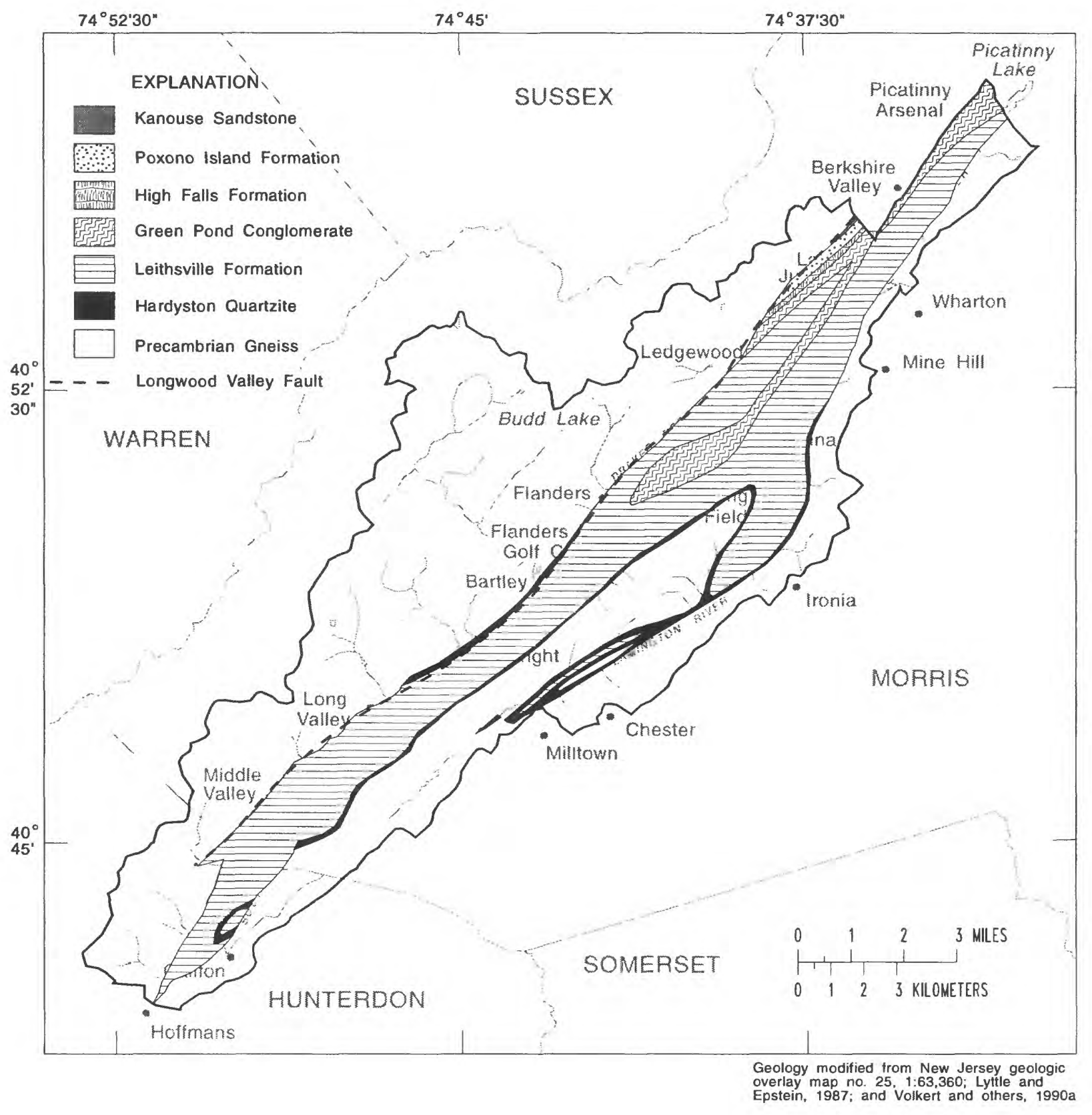

Figure 3. Generalized bedrock geology of the study area. 
tom sediments, colluvium, till, Paleozoic bedrock, and weathered carbonate-rock clay residuum. Examples of the configuration of the hydrogeologic units are shown in generalized hydrogeologic sections on plates 1c-1f.

The traces of the generalized hydrogeologic sections are shown on plates $1 \mathrm{a}-\mathrm{b}$. The sections were constructed from the topographic data shown on plate 1a, and from the maps of discretized thicknesses of aquifers and confining units shown on figures 4 - 9 . The sections were not used to define the hydrogeologic framework; they are presented in order to depict the vertical configuration of the framework that was defined previously by means of the thickness maps. The thicknesses shown on figures 4 - 9 are highly generalized and, therefore, the sections shown on plates 1c-f also are highly generalized; actual thicknesses at specific locations may be substantially different from those shown. These sections do provide, however, an indication of the thicknesses and configuration of aquifers and confining units in several representative areas within the study area.

The process of defining the hydrogeologic framework is complicated by abrupt facies changes over short lateral distances and subtle changes in lithology with depth. In many areas, drillers' logs of wells only a few tens of feet from each other contained reports of considerably different depths to bedrock and lithologies. As a result, the framework description is highly generalized in many areas.

\section{Model Representation of Hydrogeologic Units}

The hydrogeologic framework developed from results of previous investigations was discretized for use in development of a numerical ground- water-flow model. The numerical model is a simplified mathematical representation of the flow system, and the manner in which the framework was discretized reflects the level of this simplification. Framework discretization involved designing a grid and then estimating the thickness of each hydrogeologic unit present in the column represented by a vertical series of grid cells. Estimated thicknesses were then used to determine representative top and bottom altitudes of aquifer layers, which are confined in places, and the altitude of the bottom of the unconfined upper valleyfill aquifer layer. Estimated thicknesses of confining units and aquifers were used in determining representative leakances. A Geographic Information System was used extensively in the discretization process.

A three-layer, finite-difference grid was designed to provide sufficient resolution to simulate individual tributary stream reaches and to reasonably simulate flow through parts of aquifers where they narrow between constricting valley walls. Each of the three aquifers simulated is represented by a single model layer: The upper valley-fill aquifer, the lower valley-fill aquifer, and the carbonate-rock aquifer are represented by model layers 1, 2, and 3, respectively (fig. 10). The grid was designed with 44 rows and 256 columns, with a uniform grid spacing of 500 feet, and 6,407 active cells (pl. 1b). The notation used in this report for identifying model cells is (layer, row, column). The grid was oriented along strike and the valley axis (southwest-northeast) in order to parallel the direction of horizontal anisotropy in the carbonate-rock aquifer. The following descriptions of individual hydrogeologic units refer to figures $4-9$, which are maps showing the discretized thickness of the hydrogeologic units as used in simulations.

\section{Valley-Fill Aquifer System}

The valley-fill aquifer system is largely the result of Quaternary glacial processes that filled preglacial valleys with sediment in stages. Material deposited through glacial activity generally can be divided into two types--till and stratified drift. Till refers to a mixture of clay, silt, sand, and gravel that is carried and deposited by the glacier. Till is typically unsorted and, consequently, is less permeable than coarse, well-sorted materials. Stratified drift refers to materials deposited by meltwater during movement of the glacier or by streamflow into glacial lakes formed by ice-blocked proglacial rivers. Stratified drift is sorted by flowing water into homogenous layers. The texture of the material present in the layers varies as a result of changes in streamflow velocity during the glacial period. Warm or wet periods commonly result in a greater meltwater and streamflow velocity than cool or dry periods; therefore, coarse materials, such as 


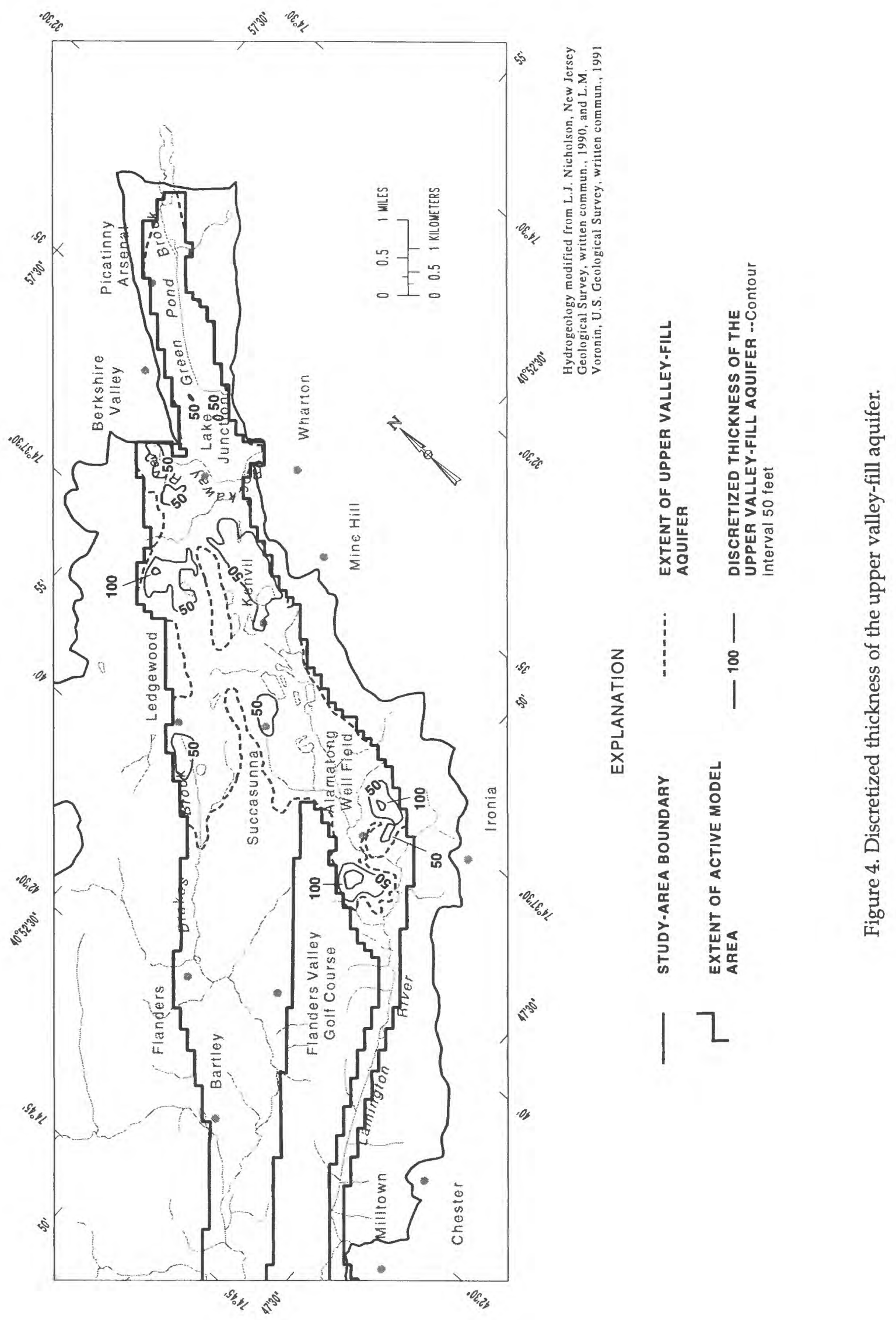




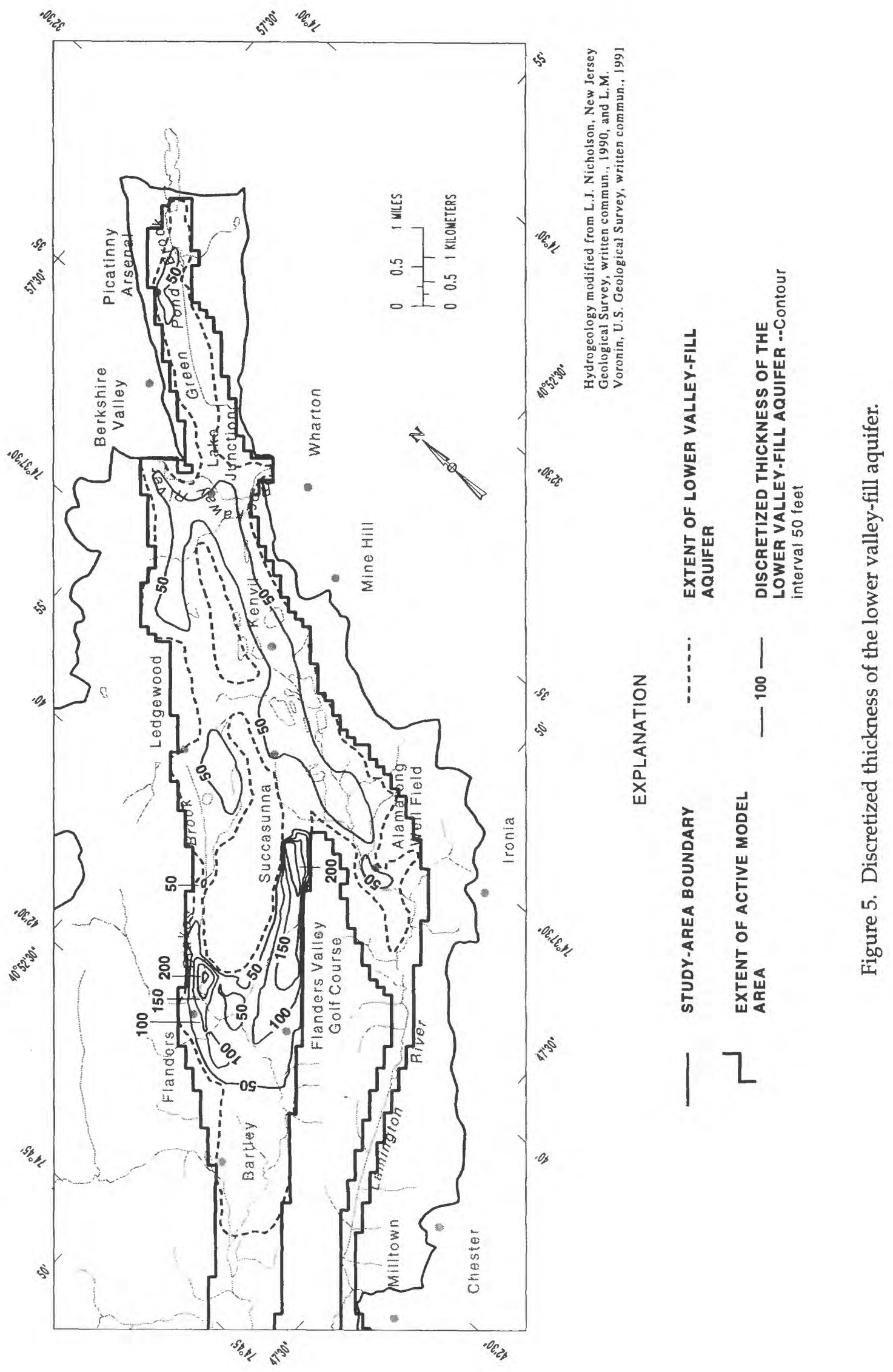




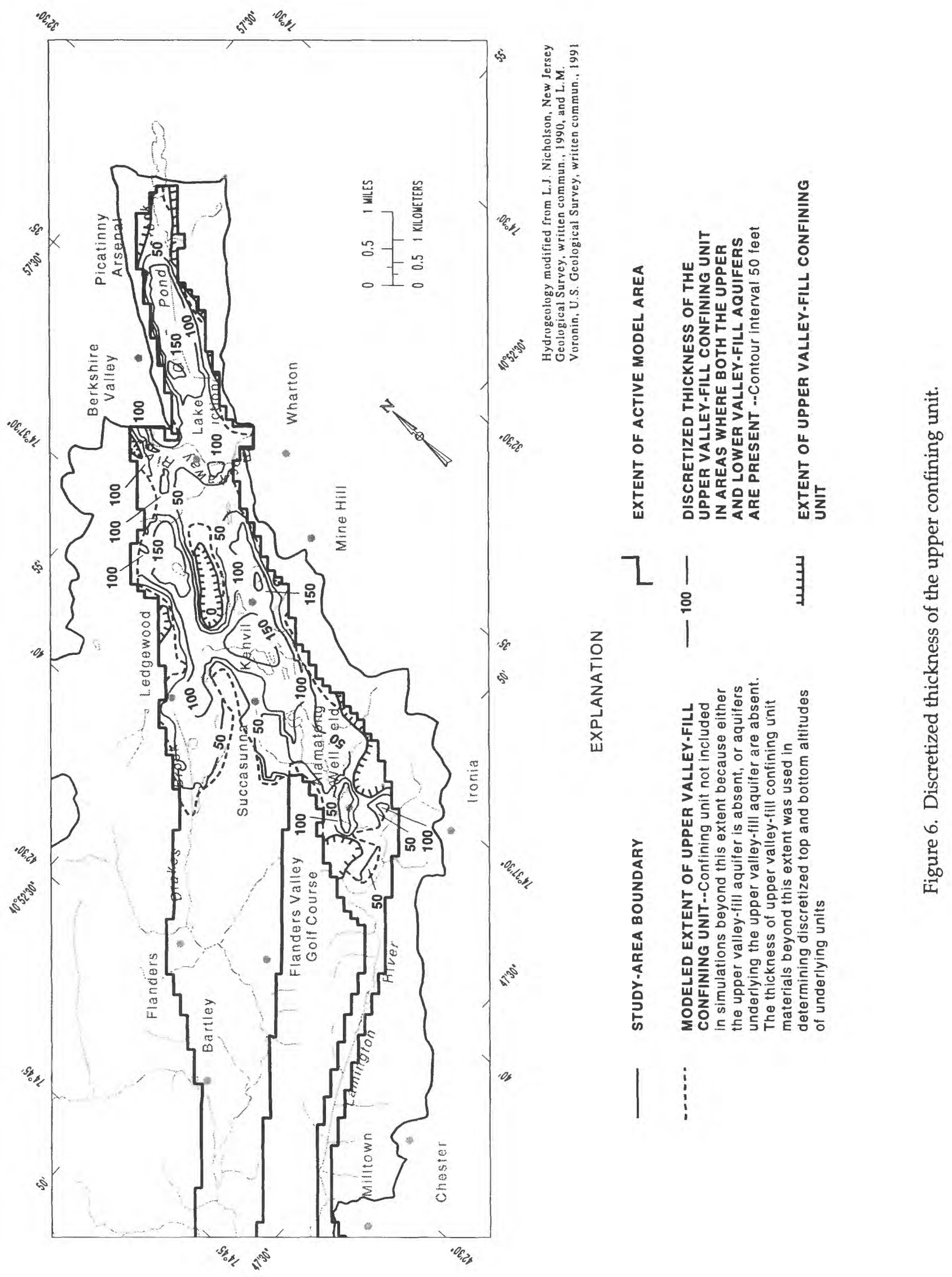




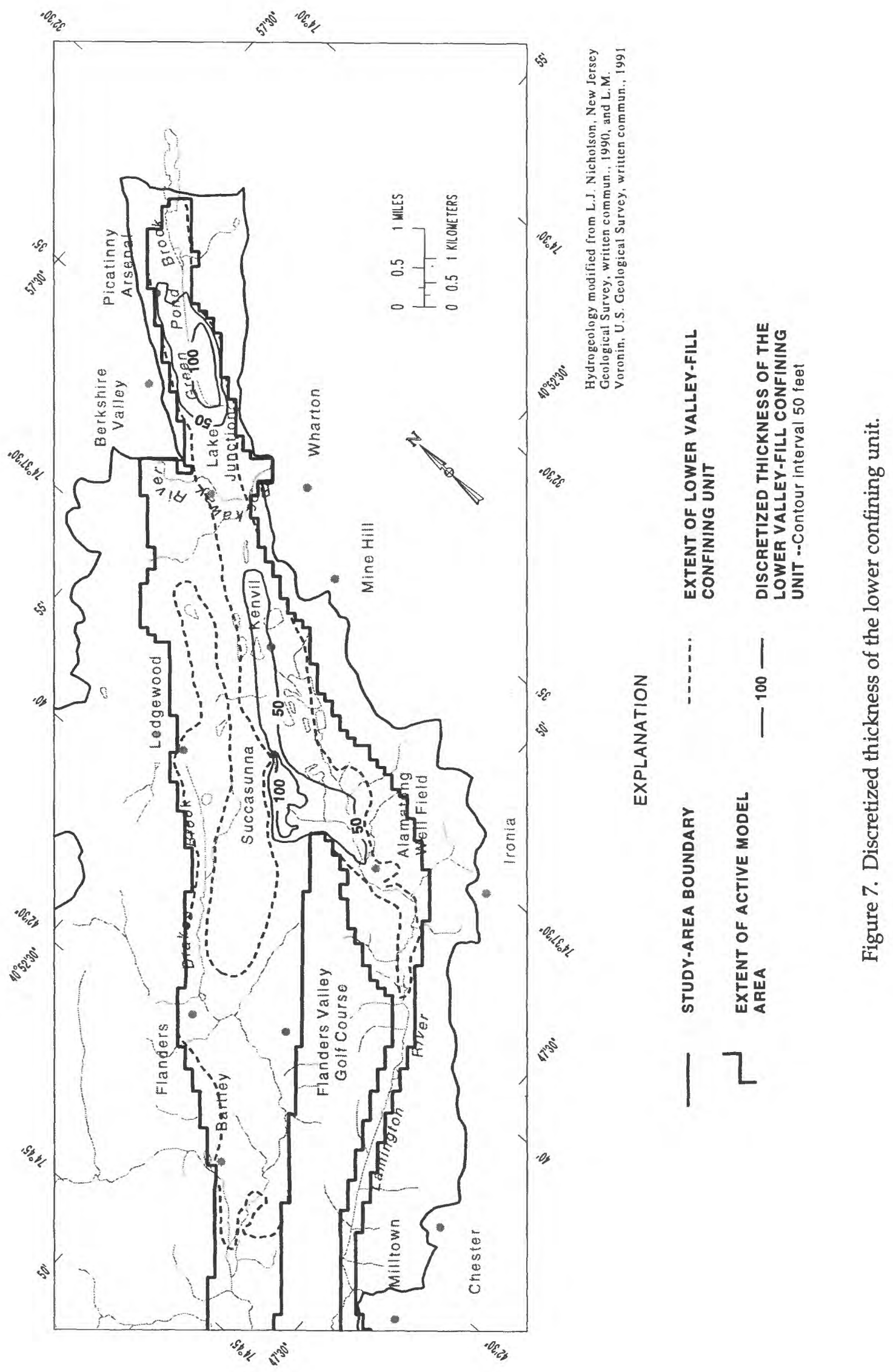




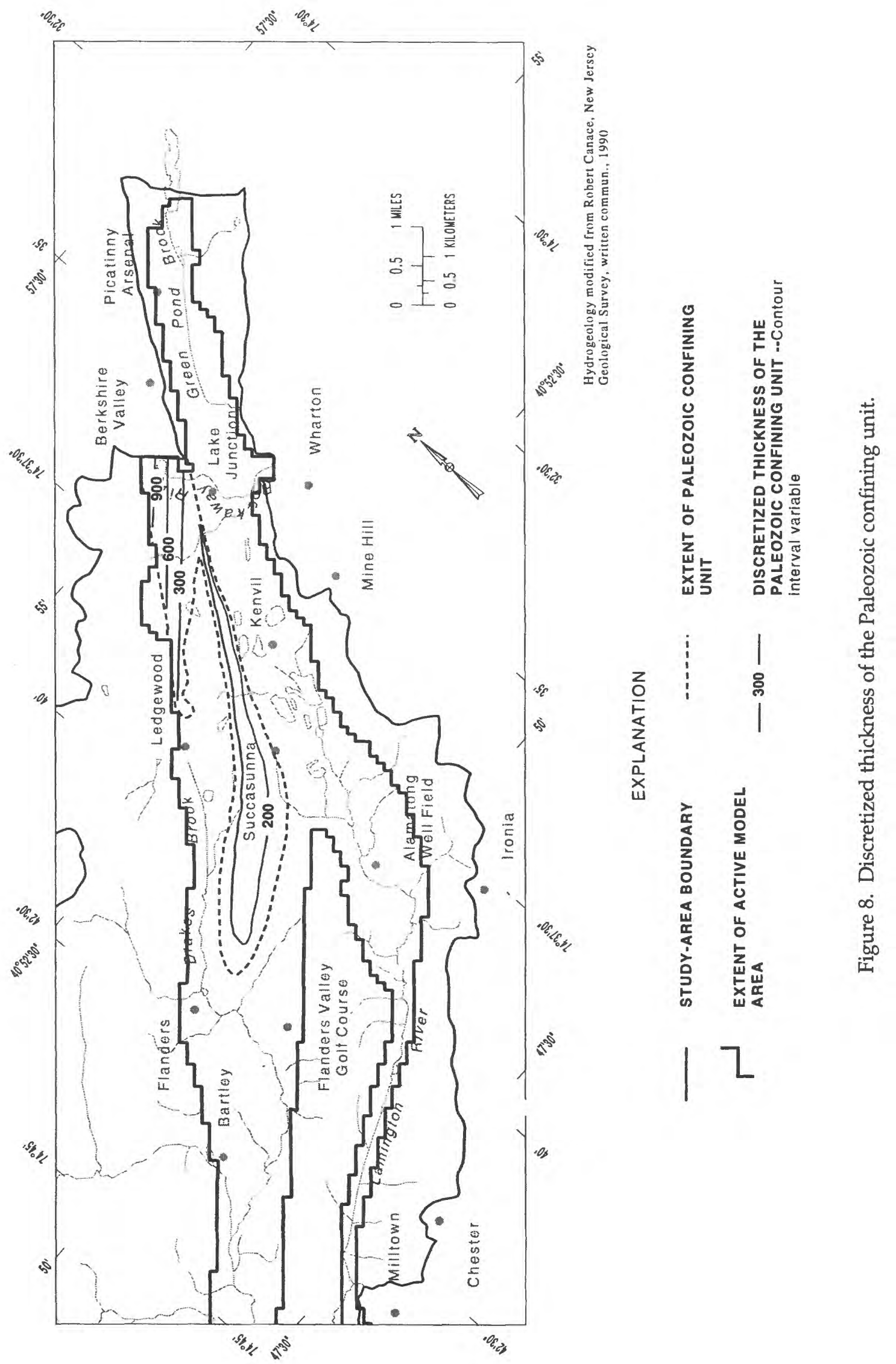




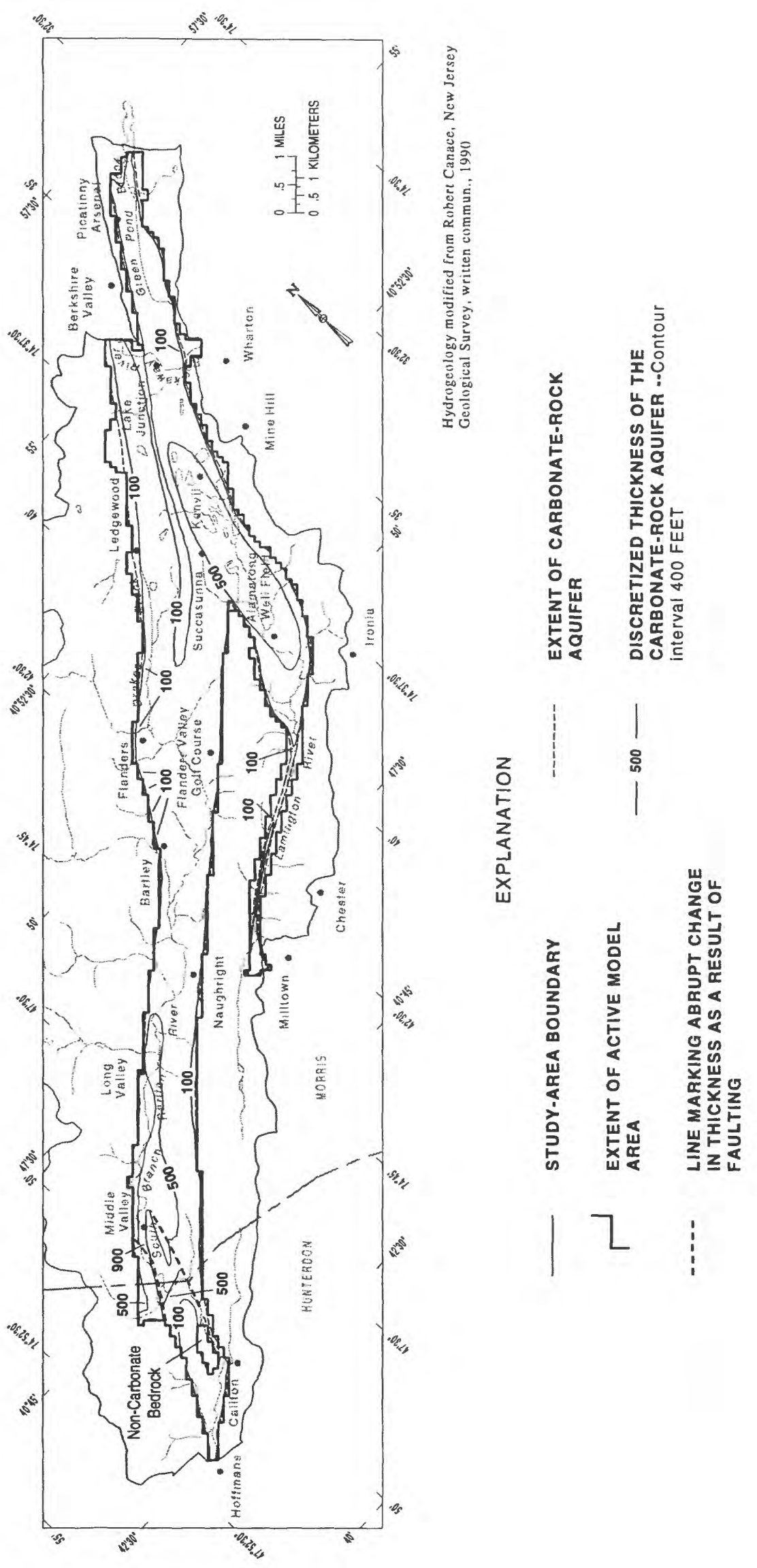

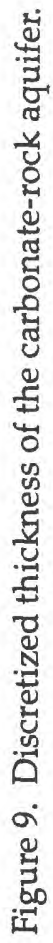




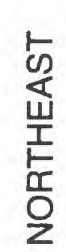

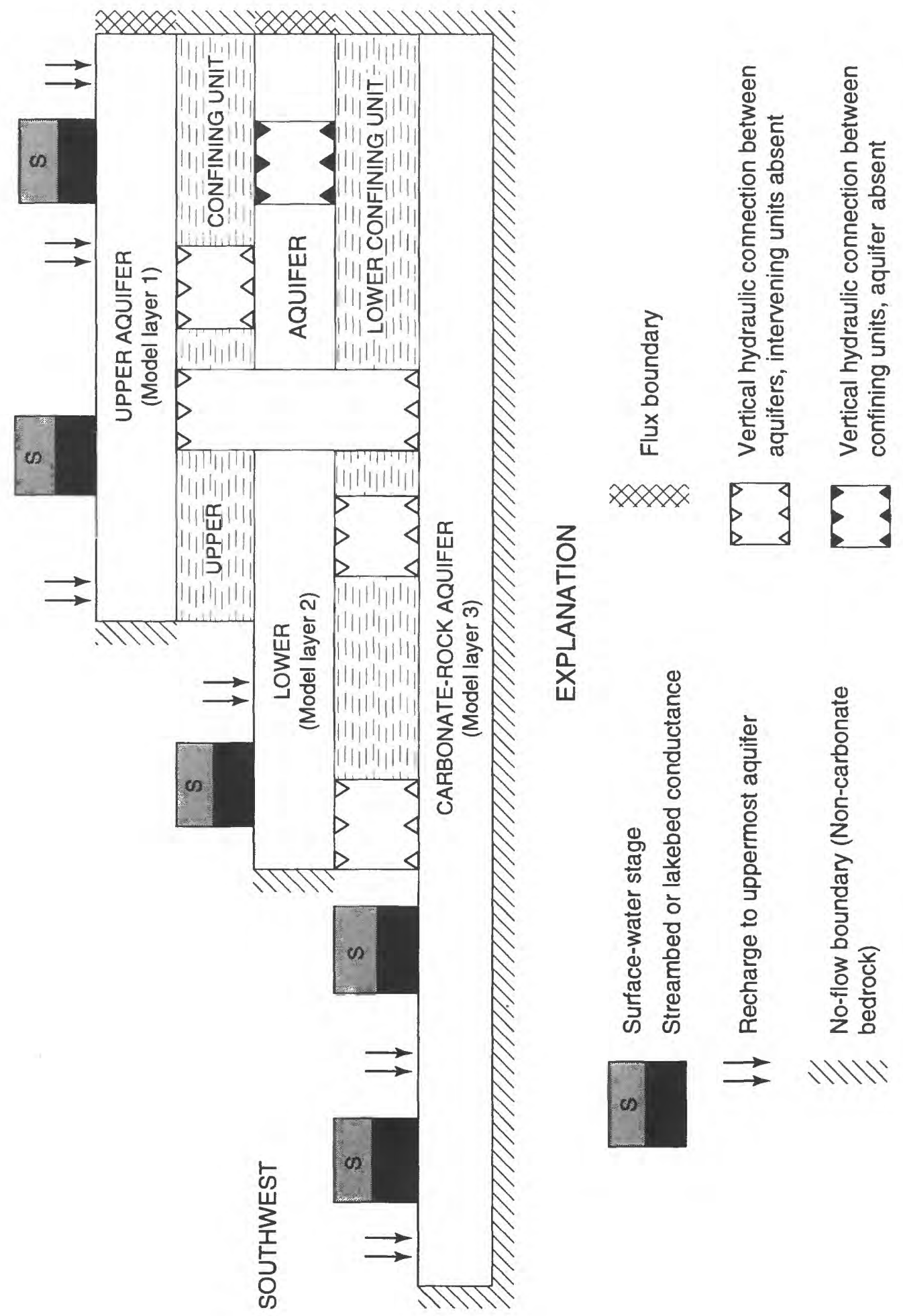

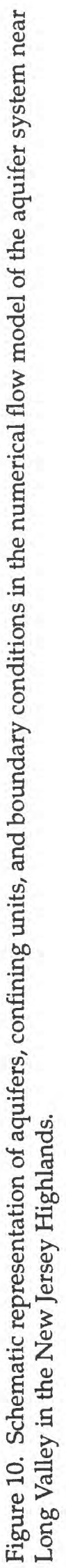


sand and gravel, are deposited during warm, wet periods, whereas finer, stratified sediments, such as clay and silt, are deposited during periods of lower meltwater and streamflow velocity. Other valley-fill sediments present in the study area include colluvium and postglacial alluvium. In some areas, weathered bedrock residuum underlies valley-fill sediments. For the purposes of defining the hydrogeologic framework, the weathered bedrock residuum has been grouped with fine-grained valley-fill sediments, and, for simplicity, is considered part of the valley-fill confining units.

\section{Upoer vallev-fill aquifer}

The upper valley-fill aquifer extends from Picatinny Lake in the north to Ironia in the south (fig. 4), covering about 11.2 square miles. Sediments of the upper valley-fill aquifer include postglacial alluvium deposited along river channels; fluvial-deltaic sand and gravel outwash deposited in the Berkshire Valley glacial lakes, Glacial Lake Succasunna, Glacial Lake Picatinny, and Glacial Lake Denville; and terminalmoraine deposits (L.J. Nicholson, New Jersey Geological Survey, written commun., 1990). Terminalmoraine deposits are considered part of the upper valley- fill aquifer despite the slight to moderate permeability of the materials because hydraulic-head data and results of previous simulations indicate substantial ground-water flow to the Rockaway River through terminal-moraine sediments (Voronin, 1991; A.D. Gordon, U.S. Geological Survey, written commun., 1993). Zones of higher permeability material may be present within the terminal moraine, providing conduits for this flow. The thickness of the upper valleyfill aquifer ranges from zero at the valley walls to about 120 feet near Ironia, and averages about 50 feet (fig. 4).

\section{Upper valley-fill confining unit}

An upper confining unit discontinuously underlies the upper valley-fill aquifer in the northern part of the study area, separating it from an underlying lower valley-fill aquifer. In the southern part of the study area this confining unit discontinuously mantles the carbonate-rock aquifer. Upper-confining-unit sediments include fine postglacial alluvium, including swamp and marsh deposits; fine glacial lakebottom sediments; colluvium; till; terminal moraine; and weathered bedrock residuum. Near the Rockaway River, the upper part of the terminal moraine is considered to be part of the upper valley-fill aquifer and the lower part is considered to be part of the upper confining unit. Here the thickness of the terminal-moraine deposits was divided conceptually in order to separate the water- transmitting part of the terminal moraine from the underlying stratified sediments. The thickness of the upper confining unit ranges from zero at the valley walls and rock outcrops to 170 feet near Kenvil, and averages about 75 feet. In some areas, such as near Ironia, the upper confining unit is absent and the upper and lower valley-fill aquifers are in direct hydraulic contact.

Beyond the extent of the upper confining unit shown in figure 6 the unit was not incorporated in simulations because either the upper valley- fill aquifer or the lower valley-fill aquifer is absent. Figure 6 shows contours of discretized values of the thickness of the upper confining unit from Ironia to Picatinny Arsenal. In the area extending from Bartley to Califon and from Chester to Ironia, the sediments comprising the unit are present but are thin or discontinuous, and so are not considered important to the regional flow system. Ground-water flow in these sediments was not modeled in these areas. The discretized thickness of the unit in these areas was used, however, in determining the discretized altitude of the top of the underlying aquifers. In the area between Bartley and Succasunna, the overburden was interpreted as containing Illinoian terminal-moraine deposits and clayey bedrock residuum, and so was mapped as part of the upper confining unit (L.J. Nicholson, New Jersey Geological Survey, written commun., 1990). This interpretation is consistent with the concept that the terminal-moraine deposits are significantly less permeable overall than the valley-fill aquifers north of this area. Results of base-flow analysis of Drakes Brook in this area show that, despite their relatively low permeability, the overburden sediments transmit ground water to Drakes Brook at a substantial rate; therefore, the uppermost deposits in this area are treated as part of a water-bearing unit in the analysis of the regional flow system. Consequently, the uppermost sediments in this area were considered part of the lower valley-fill aquifer for modeling purposes, as discussed below. 


\section{Lower vallev-fill aquifer}

The lower valley-fill aquifer discontinuously underlies the upper confining unit, and extends over about 16.2 square miles from Picatinny Lake in the north to Ironia and Bartley in the south (fig. 5). It extends farther down the valley of Drakes Brook than the upper valley-fill aquifer. The lower valley-fill aquifer consists primarily of glacial outwash of Illinoian to Wisconsinan age in the north, where it is confined, and primarily of pre-Wisconsinan till near Flanders, where it is unconfined. The thickness of the lower valleyfill aquifer ranges from zero near valley walls to 240 feet in the area between Succasunna and Flanders. The average thickness is about 50 feet. As discussed previously, the lower valley-fill aquifer in the area from Succasunna to Bartley includes sediments that are mapped as part of the upper confining unit (L.J. Nicholson, New Jersey Geological Survey, written commun., 1990), but were simulated as part of the lower valley-fill aquifer in order to evaluate their water-bearing role in the regional ground-water system. Glacial sediments are not considered important to regional ground-water flow south of the confluence of Drakes Brook and the South Branch Raritan River; therefore, for the purposes of this analysis, the extent of the lower valley-fill aquifer terminates near this river confluence. Drillers' logs of two wells located near this confluence support this concept; the logs of wells 27-1701 and 27-1106, (pl. 1a) indicate depths to the carbonate-rock aquifer of only 2 and 27 feet, respectively.

\section{Lower vallev-fill confining unit}

The lower valley-fill confining unit discontinuously underlies the lower valley-fill aquifer and extends from Picatinny Lake in the north to Ironia and Bartley in the south (fig. 7). This confining unit consists of clay residuum and Illinoian till. Similar materials make up the upper confining unit in the southern part of the study area where the lower valley-fill aquifer is not present. The upper and lower valley-fill confining units are differentiated only in areas where both the upper and lower valley-fill aquifers are present (L.J. Nicholson, New Jersey Geological Survey, written commun., 1990). The thickness of the lower valleyfill confining unit ranges from zero near valley walls to 135 feet at Succasunna. The average thickness is about 50 feet. In the area from Bartley to Succasunna, sediment overlying the carbonate-rock aquifer has been mapped previously as part of the upper confining unit but was simulated as part of the lower valleyfill aquifer and lower confining unit. The presence of an extensive yellow clay residuum mantling the carbonate-rock aquifer as documented in many lithologic and drillers' logs of well boreholes near Flanders supports the concept that sediments comprising the lower valley-fill aquifer are hydraulically separated from the underlying carbonate-rock aquifer in this area. Water-level data supporting this concept are discussed later.

\section{Paleozoic Rock Units}

Bedrock underlying the unconsolidated sediments includes conglomerate, sandstone, shale, and carbonate rock (primarily dolomite) of Paleozoic age, and gneiss of Precambrian age (table 1). The carbonate rock is highly permeable in many areas and is considered an aquifer, whereas the other bedrock units are generally less permeable and, for the purposes of this study, are considered confining units or barriers to flow.

\section{Paleozoic confining unit}

In northern parts of the study area, rocks of Devonian and Silurian age are present, consisting of conglomerate, sandstone, and shale. 'These rock units include the Kanouse Sandstone, Poxono Island Formation, High Falls Formation, and Green Pond Conglomerate (fig. 3). In some places--for example, in Succasunna--these rocks underlie valley-fill sediments. In other areas--for example, along the northwestern boundary of Picatinny Arsenal--they form ridgetops. The thickness of these rocks is poorly known, but is probably hundreds of feet near Berkshire Valley. The permeability of these rocks is variable. In topographic lows, for example, the Green Pond Conglomerate of Silurian age consists mostly of a friable sandstone, and relatively large yields and specific capacities of two wells tapping this formation have been 
reported (Gill and Vecchioli, 1965, p. 22). In topographically high areas, however, well yields and specific capacities are lower. Because these rocks are not used extensively for water supply, they are considered to comprise a confining unit for the purposes of this study. The extent and discretized thickness of the confining unit are shown in figure 8.

\section{Carbonate-rock aquifer}

The dolomite rock of the Leithsville Formation of Cambrian age underlies most of the valleys in the study area (fig. 3), and underlies the Paleozoic confining unit where both are present (pl. 1f). In some areas, the Allentown Dolomite Formation of Cambrian age may overlie the Leithsville Formation (Volkert and others, 1990a). These dolomite units together are referred to in this report as the carbonate-rock aquifer. The carbonate- rock aquifer extends from Picatinny Lake in the north to Hoffmans in the south, covering an area of about 30 square miles (fig. 9). The unit is generally bounded by faults at the northwestern boundary (fig. 3) and pinches out at the southeastern boundary. Faults within the unit have also been reported (Robert Canace, New Jersey Geological Survey, written commun., 1990). The carbonate-rock aquifer consists primarily of dolomite rock, which can be highly permeable and highly weathered to depths of hundreds of feet. Cuttings from several test-well boreholes have included soft, highly weathered rock fragments. Records of many other wells drilled in the study area indicate that a thick yellow or orange clay residuum was encountered immediately above the carbonate bedrock. Large fractures and solution channels, some several feet across, also are common in wells in this unit at depths of up to hundreds of feet. Well yields of $2,000 \mathrm{gal} / \mathrm{min}$ and specific capacities of more than $1,000(\mathrm{gal} / \mathrm{min}) / \mathrm{ft}$ have been reported in drillers' logs, indicating that the unit is highly permeable in some places. In other areas the carbonate rock is hard and unweathered, fractures are tight, and yields and specific capacities of wells tapping it are orders of magnitude lower, indicating that the bulk permeability of the rock encountered is much lower. Thus, the carbonate-rock aquifer is characterized by highly variable permeability, yet it supplies water for several communities and many private domestic and commercial users. Water-transmitting properties of the carbonate-rock aquifer are discussed in detail later. The thickness of the unit reaches 900 feet near Middle Valley and averages about 300 feet. The potential for high yields is a major impetus for interest in the aquifer as a source of additional water supply in the study area.

\section{Other Rock Units}

Throughout the study area, the carbonate-rock aquifer is underlain by the Hardyston Quartzite of Cambrian age; the quartzite is underlain by gneissic (crystalline) rock of Precambrian age (pl. 3 ). On the hydrogeologic sections in this report, these crystalline rocks are denoted as "non- carbonate bedrock."

The Hardyston Quartzite, the oldest Cambrian unit in the study area, is a thin quartzite conglomerate of low porosity with intervening units of shale and sandstone. The unit is considered to be adequate for supplying water for domestic purposes, but commonly does not provide large yields (Kasabach, 1966, p. 26).

Precambrian crystalline rocks underlie the Paleozoic rocks and form many of the ridges surrounding the study area. The primary porosity of these rocks is negligible, and well yields depend on the number and size of intersecting fractures. Wells that intersect faults or fault zones commonly are more productive than those that do not. Although the crystalline rocks provide some water for public and private domestic and commercial supplies, they do not account for a large percentage of water supply in the study area, and therefore, are not a focus of this study. Although the characteristics of these rocks were considered in formulating conceptual hydrologic boundaries of the valley-fill and carbonate-rock aquifer system, they are considered to be separate from that system for the purposes of this study. 


\section{Hydraulic Properties of Aquifers and Confining Units}

Information used to estimate hydraulic properties of aquifers and confining units included values determined through previous investigations, geophysical logs, drillers' logs, laboratory tests of permeability and porosity, well-performance tests, multiwell aquifer tests, and results of simulations of the groundwater-flow system. Geophysical logs and drillers' logs provided qualitative information on the nature of aquifer and confining-unit materials, and this information was considered in developing concepts of the distributions of aquifer and confining-unit properties. Results of laboratory analyses provided a direct determination of some hydraulic properties of two samples of aquifer and confining-unit materials. The availability of data on well performance varied among the three aquifers. Few data were available for the upper valley-fill aquifer, and the data available for the lower valley-fill aquifer provided for only a rough estimate of a representative hydraulic conductivity of that unit. Well-performance-test data for the carbonate-rock aquifer, some collected during this study and some reported by drillers, were available in sufficient quantity to provide a rational means to distinguish some areas of relatively high and low permeability within the aquifer. Aquifer-test results provided data that were useful in quantitative analyses of hydraulic properties. Results of simulations of the ground-water system provided a means to evaluate specific estimates of the distribution of hydraulic properties, and to determine the relative importance of particular properties in controlling the flow of ground water.

\section{Upper Valley-Fill Aquifer}

Hydraulic characteristics of the upper valley-fill aquifer sediments have been estimated by previous investigators. A.D. Gordon (U.S. Geological Survey, written commun., 1993) estimated that the horizontal hydraulic conductivity of the upper valley-fill aquifer in the upper Rockaway River valley ranges from 8 to $300 \mathrm{ft} / \mathrm{d}$. Voronin (1991) estimated that the hydraulic conductivity of individual stratified layers at Picatinny Arsenal ranges from 18 to $500 \mathrm{ft} / \mathrm{d}$. Voronin estimated the storage coefficient of the upper valley-fill aquifer to be 0.05 . Hill's (1985) trial-and-error estimates of the hydraulic conductivity of the aquifer range from 0.3 to $17,280 \mathrm{ft} / \mathrm{d}$, with estimates for most areas exceeding $250 \mathrm{ft} / \mathrm{d}$.

The yields of 12 wells tapping the upper valley-fill aquifer in the study area range from 1 to 530 $\mathrm{gal} / \mathrm{min}$. The specific capacity of four of these wells ranges from 2.9 to $45.9(\mathrm{gal} / \mathrm{min}) / \mathrm{ft}$.

Several aquifer tests of the valley-fill aquifers were conducted prior to this study; the locations of these tests are shown in figure 11, and the results of the tests are summarized in table 2. Tests of the valleyfill aquifers are complicated by abrupt lithologic heterogeneity and complex hydrologic boundaries, which can make interpretations of aquifer-test results difficult. Methods used to determine aquifer characteristics from results of tests conducted prior to this study do not account for such complexities, thereby limiting the usefulness of the estimates. For example, a test of a Wharton Water Department well resulted in an unrealistically high estimate of hydraulic conductivity, probably as a result of the effect of induced stream infiltration, which is known to occur near the test site (Lapham, 1989, p. 26). These estimates can provide a rough, first approximation of aquifer characteristics, however.

The distribution of horizontal hydraulic conductivity of the upper valley-fill aquifer used in simulations is shown in figure 12. The values range from 17 to $130 \mathrm{ft} / \mathrm{d}$. This distribution of horizontal hydraulic conductivity resulted in the best match between simulated and observed head distributions. The highest value $(130 \mathrm{ft} / \mathrm{d})$ was necessary at the northernmost end of the aquifer to provide adequate flow from the boundary representing Picatinny Lake to pumped wells at Picatinny Arsenal. The lowest value (17 ft/d) was necessary for consistency between simulated and measured head gradients northeast of Ledgewood. 


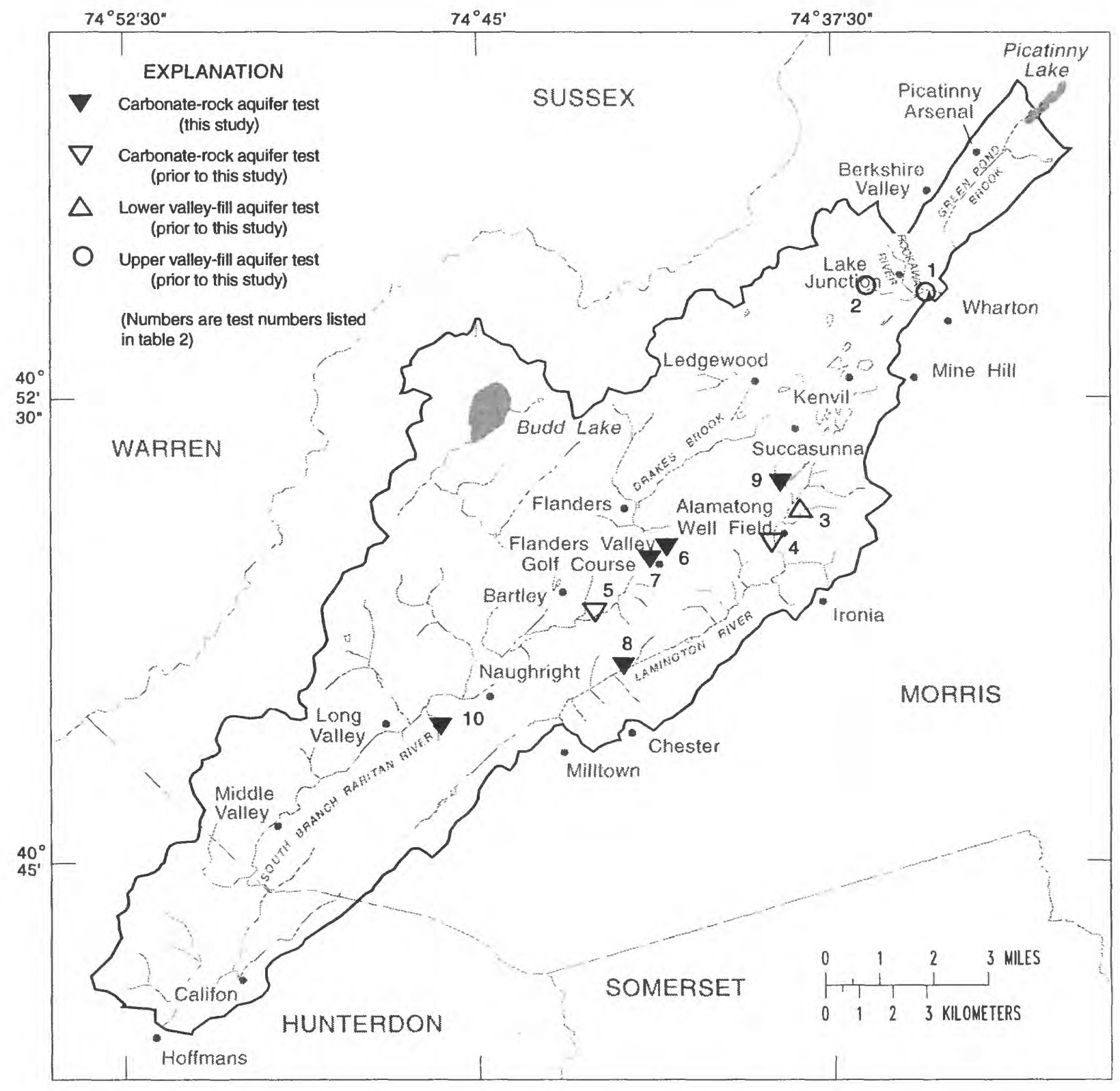

Figure 11. Location of aquifer-test sites in the study area. 
$[--$, not applicable $]$

\begin{tabular}{|c|c|c|c|c|c|c|c|c|}
\hline $\begin{array}{c}\text { Test } \\
\text { number }\end{array}$ & $\begin{array}{l}\text { Test identifier } \\
\text { (pumped well } \\
\text { number }{ }^{2} \text { ) }\end{array}$ & $\begin{array}{l}\text { Date } \\
\text { of } \\
\text { test }\end{array}$ & $\begin{array}{l}\text { Method } \\
\text { of test } \\
\text { analysis }^{3}\end{array}$ & $\begin{array}{l}\text { Thickness } \\
\text { of aquifer } \\
\text { tested } \\
\text { (feet) }\end{array}$ & $\begin{array}{l}\text { Trans- } \\
\text { missivity } \\
\text { (feet } \\
\text { squared } \\
\text { per day) }\end{array}$ & $\begin{array}{l}\text { Hydraulic } \\
\text { conductivity } \\
\text { (feet per } \\
\text { day) }\end{array}$ & $\begin{array}{l}\text { Storage } \\
\text { coefficient }\end{array}$ & $\begin{array}{l}\text { Source of } \\
\text { information }\end{array}$ \\
\hline \multicolumn{9}{|c|}{ Upper valley-fill aquifer } \\
\hline 1 & $\begin{array}{l}\text { Wharton Water Dept. } \\
\text { Wharton, NJ } \\
(27-0826)\end{array}$ & -- & NR & 30 & 25,350 & 845 & $5.1 \times 10^{-4}$ & $\begin{array}{l}\text { Gill and Vecchioli, } 1965 \text {, } \\
\text { p. } 28\end{array}$ \\
\hline 2 & $\begin{array}{l}\text { NJDEP test well } 10 \\
(27-0921)\end{array}$ & -- & $\mathrm{T}$ & 20 & 148 & 7.4 & $8.1 \times 10^{-2}$ & Hill, 1985 , p. 180 \\
\hline \multicolumn{9}{|c|}{ Lower valley-fill aquifer } \\
\hline 3 & $\begin{array}{l}\text { MCMUA well } 4 \\
(27-1324)\end{array}$ & $7 / 82$ & $\mathrm{C}, \mathrm{S}$ & 54 & 13,800 & ${ }^{7} 260$ & - & $\begin{array}{l}\text { Data provided by Thomas } \\
\text { Branch, Morris County } \\
\text { Municipal Utilities Authority } \\
\text { written commun., } 1990\end{array}$ \\
\hline \multicolumn{9}{|c|}{ Carbonate-rock aquifer } \\
\hline 4 & $\begin{array}{l}\text { MCMUA well } 5 \\
(27-1090)\end{array}$ & $11 / 85$ & $\mathrm{C}, \mathrm{M}$ & 189 & 5,550 & 29 & - & $\begin{array}{l}\text { E. T. Killam Assoc., written } \\
\text { commun., } 1985\end{array}$ \\
\hline 5 & $\begin{array}{l}\text { Mt. Olive well } 3 \\
(27-1093)\end{array}$ & $10 / 84$ & $\mathbf{L}, \mathbf{M}$ & 179 & 7,700 & 43 & $2.7 \times 10^{-2}$ & $\begin{array}{l}\text { George Blyskun, New Jersey } \\
\text { Geological Survey, written } \\
\text { commun., } 1988\end{array}$ \\
\hline 6 & $\begin{array}{l}\text { MCMUA FLI } \\
(27-1728)\end{array}$ & $9 / 90$ & $\mathrm{G}, \mathrm{M}$ & 300 & $\begin{array}{r}47,800- \\
259,200\end{array}$ & ${ }^{4} 26-864$ & $\begin{array}{l}52.5 \times 10^{-4} \\
1.5 \times 10^{-2}\end{array}$ & This study \\
\hline 7 & $\begin{array}{l}\text { MCMUA FL2 } \\
(27-1727)\end{array}$ & $8 / 90$ & G,M & 300 & $\begin{array}{r}47,800- \\
259,200\end{array}$ & ${ }^{4} 26-864$ & $\begin{array}{l}{ }^{5} 2.5 \times 10^{-4} \\
1.5 \times 10^{-2}\end{array}$ & This study \\
\hline 8 & $\begin{array}{l}\text { USGS BR-4 } \\
(27-1126)\end{array}$ & $\begin{array}{c}4 / 30 / 90 \\
5 / 1 / 90\end{array}$ & $\mathrm{C}, \mathrm{S}$ & 3 & ${ }^{6} 1,100$ & ${ }^{6} 367$ & - & This study \\
\hline 9 & $\begin{array}{l}\text { Roxbury Water Co. } \\
1-A \\
(27-1733)\end{array}$ & $1 / 90$ & $\mathrm{C}, \mathrm{M}$ & 500 & ${ }^{6} 2,100$ & $6_{4}$ & ${ }^{7} 1.0 \times 10^{-2}$ & This study \\
\hline 10 & $\begin{array}{l}\text { NJGS Drew U. well } \\
(27-1303)\end{array}$ & $4 / 90$ & $\mathrm{~T}, \mathrm{M}$ & 17 & 9,000 & ${ }^{6} 530$ & - & This study \\
\hline
\end{tabular}

\footnotetext{
${ }^{1}$ Number identifies site location shown in figure 11 .
}

${ }^{2}$ New Jersey well number; well location shown on plate la.

${ }^{3} \mathrm{~T}=$ Nonleaky analysis (Theis, 1935); C = Nonleaky analysis (Cooper and Jacob, 1946); L = Leaky analysis (Hantush and Jacob, 1955); $\mathrm{G}=$ Analysis using ground-water-flow model; $\mathrm{NR}=$ method not reported; $\mathrm{S}=$ Single-well test; $\mathrm{M}=$ Multi-well test.

${ }^{4}$ Range of values in downvalley direction over area influenced by test; at the regional scale of the analysis, crossvalley values are estimated to be lower by a factor of 7.5 .

${ }^{5}$ Lower value is confined storage coefficient; higher values is unconfined storage coefficient.

${ }^{6}$ Lower bounding value of range of probable values at site.

${ }^{7}$ Upper bounding value of range of probable values at site. 


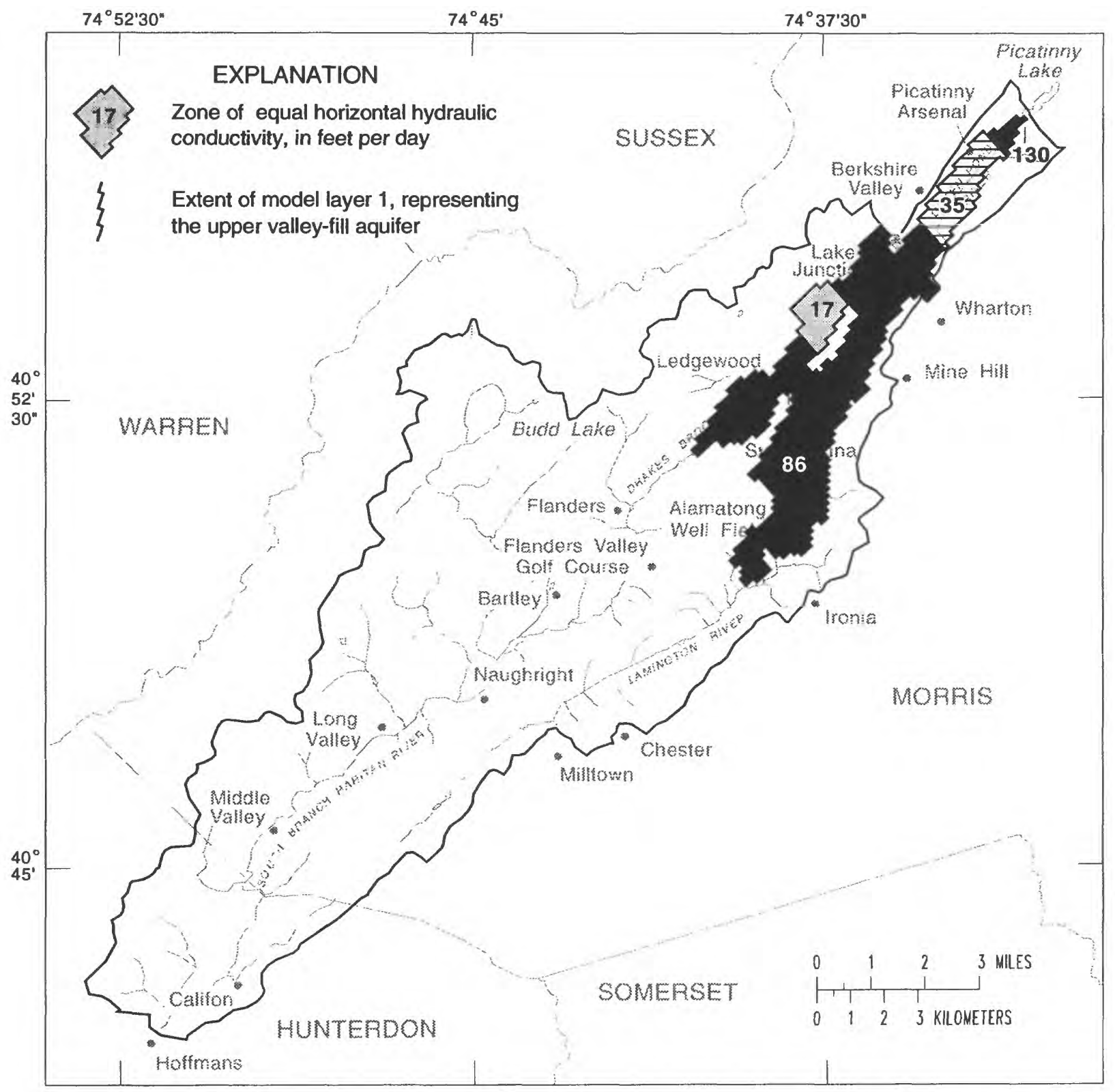

Figure 12. Extent of the upper valley-fill aquifer and distribution of horizontal hydraulic conductivity, as represented in the model (model layer 1 ). 


\section{Upper Valley-Fill Confining Unit}

Hydraulic characteristics of valley-fill confining-unit sediments in a similar setting were reported by Meisler (1976), who estimated that the vertical hydraulic conductivity of a semiconfining layer in the Passaic River valley ranges from $6.0 \times 10^{-3}$ to $4.2 \times 10^{-2} \mathrm{ft} / \mathrm{d}$. The results of the current investigation indicate that the vertical conductivity of the upper confining unit are within this range, except within the sediments of the Wisconsinan terminal moraine, where the vertical hydraulic conductivity is higher.

The tests that are known to have been conducted in the lower valley- fill aquifer were not designed to make determinations of characteristics of the upper confining unit. As a result, the understanding of the properties of this unit is derived primarily from (1) laboratory analysis of a single Shelby-tube sample from the borehole drilled near Kenvil, (2) qualitative interpretations of well logs, water-level data, and well-performance data, and (3) simulations of ground-water flow.

A Shelby-tube sample of a gray-brown, fine, sandy, clayey silt was collected from the borehole for well 27-1124 at a depth of 143 feet. The texture and color of the sample are indicative of Glacial Lake Succasunna lakebottom sediment (Stanford, 1989) and are similar to those of samples from silty/clayey zones described in well logs of many other boreholes drilled in the Succasunna and Kenvil areas that were used in mapping the thickness of the upper valley-fill confining unit by L.J. Nicholson (New Jersey Geological Survey, written commun., 1990). Results of laboratory analysis of the Shelby-tube sample showed that the vertical hydraulic conductivity was $4.03 \times 10^{-3} \mathrm{ft} / \mathrm{d}$ at an effective pressure of 7.2 tons per square foot. This value is within the expected range for silts and clays (Freeze and Cherry, 1979, p. 29) and was considered representative of the unit. The porosity of the sample was 0.384 . Head differences between the upper and lower valley-fill aquifers in the area near the location of the sampled borehole are 15 to 30 feet, indicating that the clayey silt acts as an effective confining unit. In other areas, however, the upper confining unit is more permeable, thin, or absent, allowing ground water to flow more freely between the two aquifers. The most prominent of these areas is beneath the Wisconsinan terminal moraine, where the low-permeability glacial lakebottom sediments are not present, vertical head gradients are small, and the entire overburden sequence acts as a single- rather than a dual-aquifer system.

In simulations, the hydraulic properties of the upper confining unit were intergrated into a vertical leakance term, called "Vcont," which controls the simulated flow between the upper and lower valley-fill aquifers. Vertical leakance was estimated as a function of the vertical hydraulic conductivities of the confining unit and adjacent aquifers, and the thicknesses of the respective units (McDonald and Harbaugh, 1988, p. 5- 16). In most areas where the upper confining unit separates the upper aquifer from underlying aquifers, a value of $4.3 \times 10^{-3} \mathrm{ft} / \mathrm{d}$ was used to represent the vertical hydraulic conductivity of the upper confining unit. In the areas near Picatinny Lake and the Wisconsinan terminal moraine, the values used were one and two orders of magnitude higher, respectively. The vertical hydraulic conductivity of aquifers used in leakance calculations was assumed to be less than the corresponding horizontal hydraulic conductivity by a factor of $\mathbf{1 0}$ to account for likely anisotropy in the stratified sediments. The vertical hydraulic conductivity of aquifers affects the calculated leakance values only in areas where the intervening confining unit is very thin or absent.

The distribution of vertical leakance between the upper valley-fill and underlying aquifers as represented in the model is shown in figure 13. Leakance values are highest in areas where the confining unit is absent and the aquifers are in direct hydraulic contact.

\section{Lower Valley-Fill Aquifer}

Meisler (1976) estimated that the horizontal hydraulic conductivity of a similar confined valley-fill aquifer ranges from 260 to $350 \mathrm{ft} / \mathrm{d}$, and that the storage coefficient ranges from $4 \times 10^{-5}$ to $4 \times 10^{-4}$ 


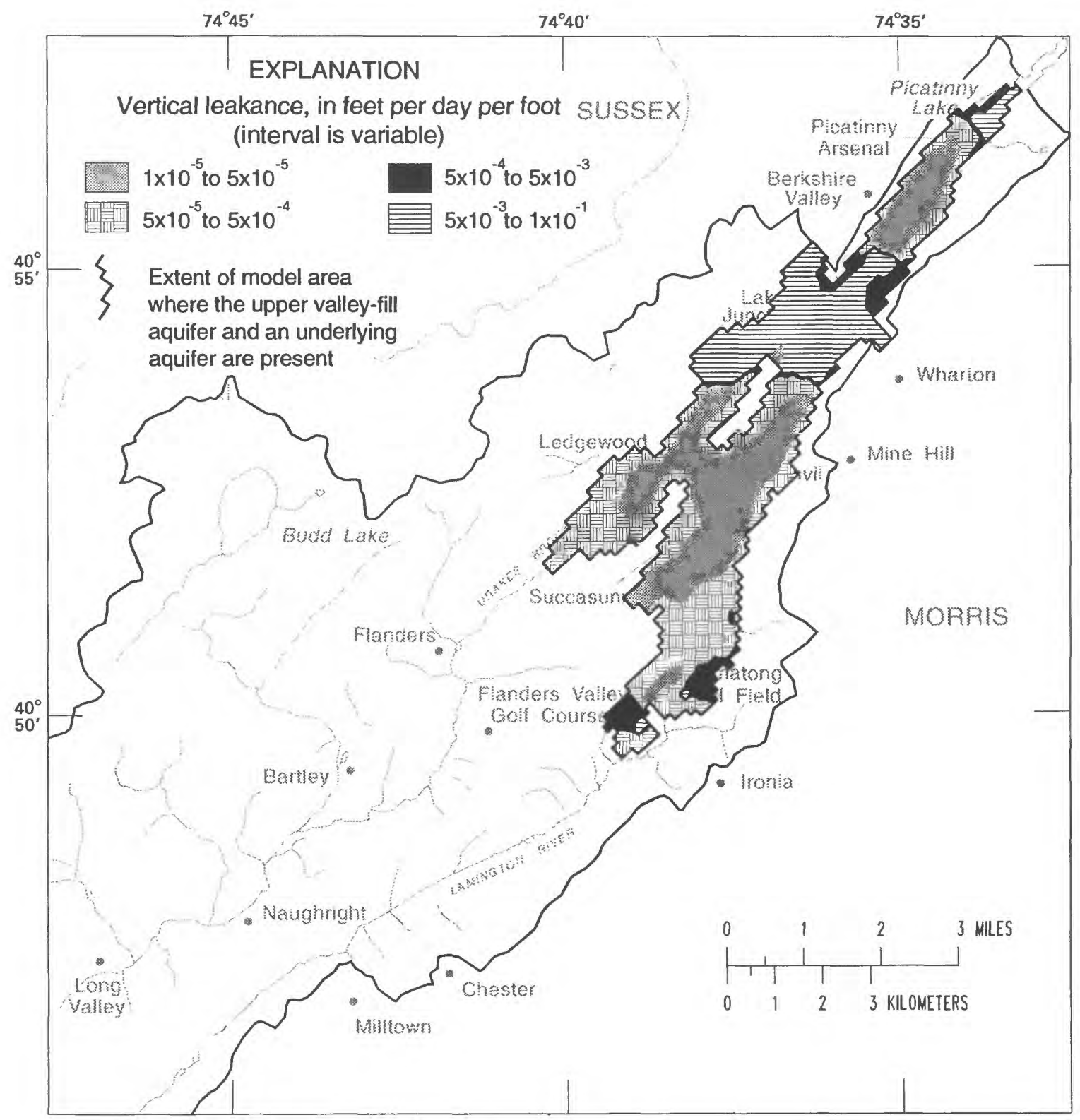

Figure 13. Distribution of vertical leakance between the upper valley-fill aquifer and underlying aquifers, as represented in the model. 
The yields of 42 wells tapping the lower valley-fill aquifer in the study area range from 3 to $1,700 \mathrm{gal} / \mathrm{min}$. The specific capacity of 12 of these wells ranges from $0.01 \mathrm{to} 93.8(\mathrm{gal} / \mathrm{min}) / \mathrm{ft}$.

The location of one aquifer test of the lower valley-fill aquifer is shown in figure 11, and the results of the test are summarized in table 2. The test site is situated in an area where the lower valley-fill aquifer is in good hydraulic connection with the carbonate-rock aquifer, and upward leakage from the carbonaterock aquifer probably affected the test results to a greater extent than other boundaries. As a result, the estimated hydraulic conductivity of $260 \mathrm{ft} / \mathrm{d}$ for the lower valley-fill aquifer is considered high.

Well-performance data were examined to obtain additional estimates of hydraulic conductivity to supplement the limited aquifer-test data for this aquifer. Hill (1985) adapted a method of determining hydraulic conductivity from specific-capacity data developed by McClymonds and Franke (1972). The method was used here to estimate a representative value of hydraulic conductivity of the lower valley-fill aquifer. The following expression was used:

$$
K=2,000 \times \frac{Q}{s L},
$$

where $\mathrm{K}$ = average hydraulic conductivity of the materials opposite the well screen, in $(\mathrm{gal} / \mathrm{d}) / \mathrm{ft}^{2}$;

$$
\begin{aligned}
\frac{Q}{S} & =\text { specific capacity, in }(\mathrm{gal} / \mathrm{min}) / \mathrm{ft} \text {; and } \\
L & =\text { length of well screen, in feet. }
\end{aligned}
$$

Because the necessary data were available for only 12 wells open to the lower valley-fill aquifer, and because aquifer characteristics calculated from results of individual performance tests are prone to considerable error, the calculated values of hydraulic conductivity were considered only in determining a single representative value of hydraulic conductivity of this aquifer. The values of hydraulic conductivity calculated from the 12 values of specific capacity range from 1.2 to $836 \mathrm{ft} / \mathrm{d}$ and are listed in table 3 . The median of these values is $81 \mathrm{ft} / \mathrm{d}$, which is considered a representative value of hydraulic conductivity of the lower valley-fill aquifer.

The distribution of hydraulic conductivity used in simulations is shown in figure 14. Values used range from 2 to $86 \mathrm{ft} / \mathrm{d}$. The narrow banded area where the value is lowest is just south of the Wisconsinan terminal moraine; permeable materials may be absent here. It is inferred from Stanford (1989, cross-section

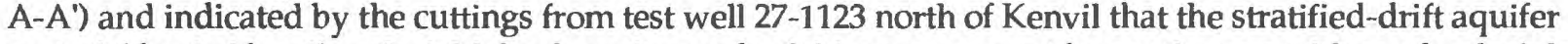
material buried by silty glacial-lake deposits south of this area may not be contiguous with sandy glaciolacustrine outwash material buried by the terminal moraine to the north, and that the two zones of permeable materials are hydraulically separated by low-permeability material.

\section{Composite Paleozoic-Rock and Lower Valley-Fill Confining Unit}

The lower valley-fill confining unit and Paleozoic-rock confining unit together form a discontinuous composite confining unit between the lower valley-fill aquifer and the carbonate-rock aquifer (pl. 1d). The hydraulic characteristics of the Paleozoic-rock confining unit have not been investigated previously, and the present understanding of these characteristics is based primarily on results of well-performance tests and ground-water-flow simulations. Gill and Vecchioli $(1965$, p. 12) noted that noncarbonate Paleozoic rocks are not important aquifers in Morris County, although they do supply some water for domestic and small public supplies. The Paleozoic-rock confining unit consists of the Green Pond Conglomerate over most of its extent. The yields of 10 wells tapping the Green Pond Conglomerate range from 2 to $50 \mathrm{gal} / \mathrm{min}$. The specific capacities of three of these wells range from 0.03 to $0.38(\mathrm{gal} / \mathrm{min}) / \mathrm{ft}$. Water-bearing properties of the other rock units forming the Paleozoic-rock confining unit are unknown. Horizontal ground-water flow in the Paleozoic-rock unit was not considered important in the flow budget of the aquifer system, and so was not simulated. The unit was simulated as a leakance that controls vertical flow in areas where overlying and underlying aquifers are present. 
Table 3. Hydraulic-conductivity values estimated from specific-capacity data for sclected wells in the lower yalley-fill aquifer

\begin{tabular}{|c|c|c|c|c|}
\hline $\begin{array}{c}\text { Well } \\
\text { number }\end{array}$ & Owner & $\begin{array}{c}\text { Specific } \\
\text { capacity } \\
\text { (gallons } \\
\text { per minute } \\
\text { per foot) }\end{array}$ & $\begin{array}{l}\text { Screen } \\
\text { length } \\
\text { (feet) }\end{array}$ & $\begin{array}{l}\text { Estimated } \\
\text { horizontal } \\
\text { hydraulic } \\
\text { conductivity } \\
\text { (feet per day) }\end{array}$ \\
\hline $27-1592$ & STULL ENGRAVING COMPANY & 0.27 & 11 & 6.7 \\
\hline $27-1323$ & MORRIS COUNTY MCMUA & 5.19 & 19 & 73 \\
\hline $27-1087$ & HERCULES INC & 93.80 & 30 & 840 \\
\hline $27-1124$ & US GEOLOGICAL SURVEY & .11 & 10 & 2.9 \\
\hline 27-1191 & STATE OF NJ & .01 & 20 & .1 \\
\hline $27-1316$ & WESTINGHOUSE ELEVATOR & 21.80 & 25 & 230 \\
\hline $27-1317$ & WESTINGHOUSE ELEVATOR & 7.88 & 18 & 120 \\
\hline $27-1324$ & WESTINGHOUSE ELEVATOR & 66.93 & 54 & 330 \\
\hline $27-1621$ & ROXBURY TWP PUBLIC LIBRARY & .79 & 1 & 210 \\
\hline $27-1622$ & FREDERICK OBRIEN & .09 & 1 & 24 \\
\hline $27-1667$ & NORMAN IVERSON & .14 & 1 & 37 \\
\hline \multirow[t]{2}{*}{$27-1668$} & EDWARD MACKOWICZ & .67 & 2 & 90 \\
\hline & & & Median: & 81 \\
\hline
\end{tabular}




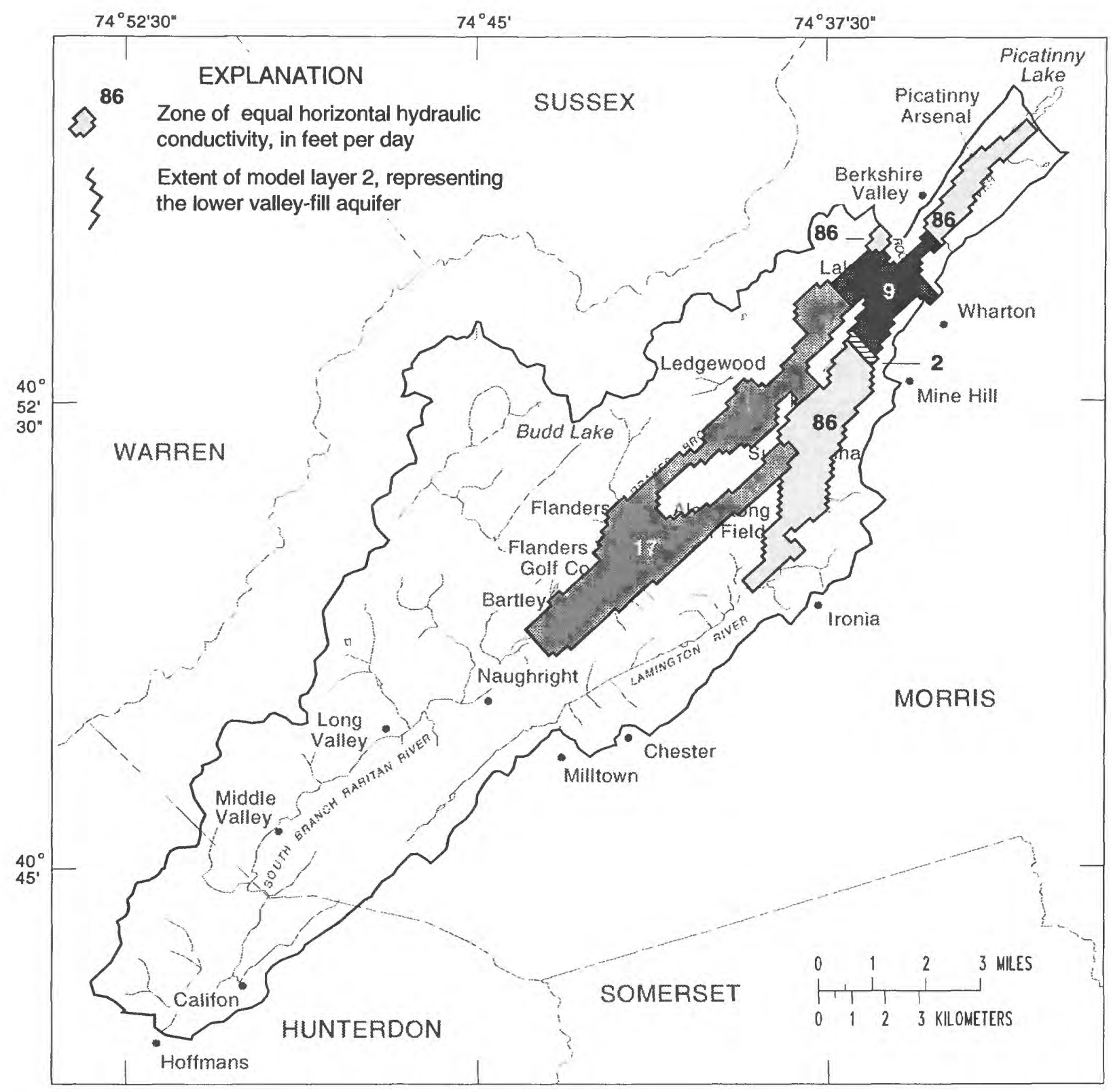

Figure 14. Extent of the lower valley-fill aquifer and distribution of horizontal hydraulic conductivity, as represented in the model (model layer 2). 
The hydraulic characteristics of the lower valley-fill confining unit, consisting of pre-late Wisconsinan till and carbonate-derived clay residuum, have not been extensively investigated prior to this study, and the present understanding of the unit is based primarily on results of simulations. Voronin (1991) simulated flow between the carbonate-rock aquifer and overlying glacial sediments at Picatinny Arsenal. Voronin assumed that the permeability of the entire thickness of weathered carbonate rock is low and represented the weathered rock as a confining layer with a vertical hydraulic conductivity of $0.5 \mathrm{ft} / \mathrm{d}$.

However, many productive wells in the present study area south of Picatinny Arsenal are open to carbonate rock that is weathered, but not completely broken down to a clay residuum. Moreover, some of the most productive water-bearing zones encountered in these carbonate-rock boreholes are present in rock that is sufficiently weathered to be very soft and brittle, but sufficiently strong to withstand internal pressures and maintain solution openings. Therefore, in the present study, only the clay residuum was considered part of the lower valley-fill confining unit. Because it is unknown whether any wells producing water adequate for even domestic use are open exclusively to this unit, well-performance data could not be used to characterize its hydraulic properties. The unit was represented in simulations as a vertical leakance that controls flow between the overlying and underlying aquifers. The values of vertical conductivity of the lower valley-fill confining unit used in vertical-leakance calculations range from $4.3 \times 10^{-4}$ to $8.6 \times 10^{-4} \mathrm{ft} / \mathrm{d}$.

A composite vertical leakance was calculated as a function of the vertical hydraulic conductivities of the Paleozoic-rock confining unit, the lower valley-fill confining unit, adjacent aquifers, and the thicknesses of the respective units. The calculation of vertical leakance is described by McDonald and Harbaugh (1988, p. 5-16). The vertical hydraulic conductivity of overlying and underlying aquifers used in these calculations was assumed to be less than the corresponding horizontal hydraulic conductivity by a factor of 10 to account for anisotropy in the stratified sediments and rocks. The vertical hydraulic conductivity of aquifers affects the calculated vertical-leakance values only in areas where the intervening confining unit is thin or absent.

The distribution of vertical leakance used in the model to represent the composite Paleozoic-rock and lower valley-fill confining unit, as well as the direct hydraulic connection between lower valley-fill aquifer and the carbonate-rock aquifer where the composite confining unit is absent, is shown in figure 15. The leakance values are highest in areas where confining units are absent, and also near Succasunna, where water-level data indicate a good hydraulic connection between the lower valley-fill aquifer and the carbonate-rock aquifer. In areas where the upper valley-fill aquifer and carbonate-rock aquifer are present but the lower valley-fill aquifer is absent, the vertical leakance between the two aquifers can be determined from leakance values shown in figures 13 and 15 by the expression

$$
L_{c}=\frac{1}{\frac{1}{L_{1}}+\frac{1}{L_{2}}},
$$

where $L_{c}=$ total vertical leakance;

$L_{1}=$ vertical leakance of upper valley-fill aquifer and underlying upper confining unit, if present; and

$L_{2}$ = vertical leakance of the carbonate-rock aquifer and overlying composite confining unit, if present.

\section{Carbonate-Rock Aquifer}

The hydraulic properties of carbonate-rock aquifers in New Jersey settings similar to the present study area have been estimated by other investigators. Hutchinson (1981) simulated ground-water flow in a similar carbonate-rock setting in the Pequest River Valley, New Jersey, situated about 6 miles northwest of the present study area. The horizontal hydraulic conductivity of the Leithsville Formation used in 


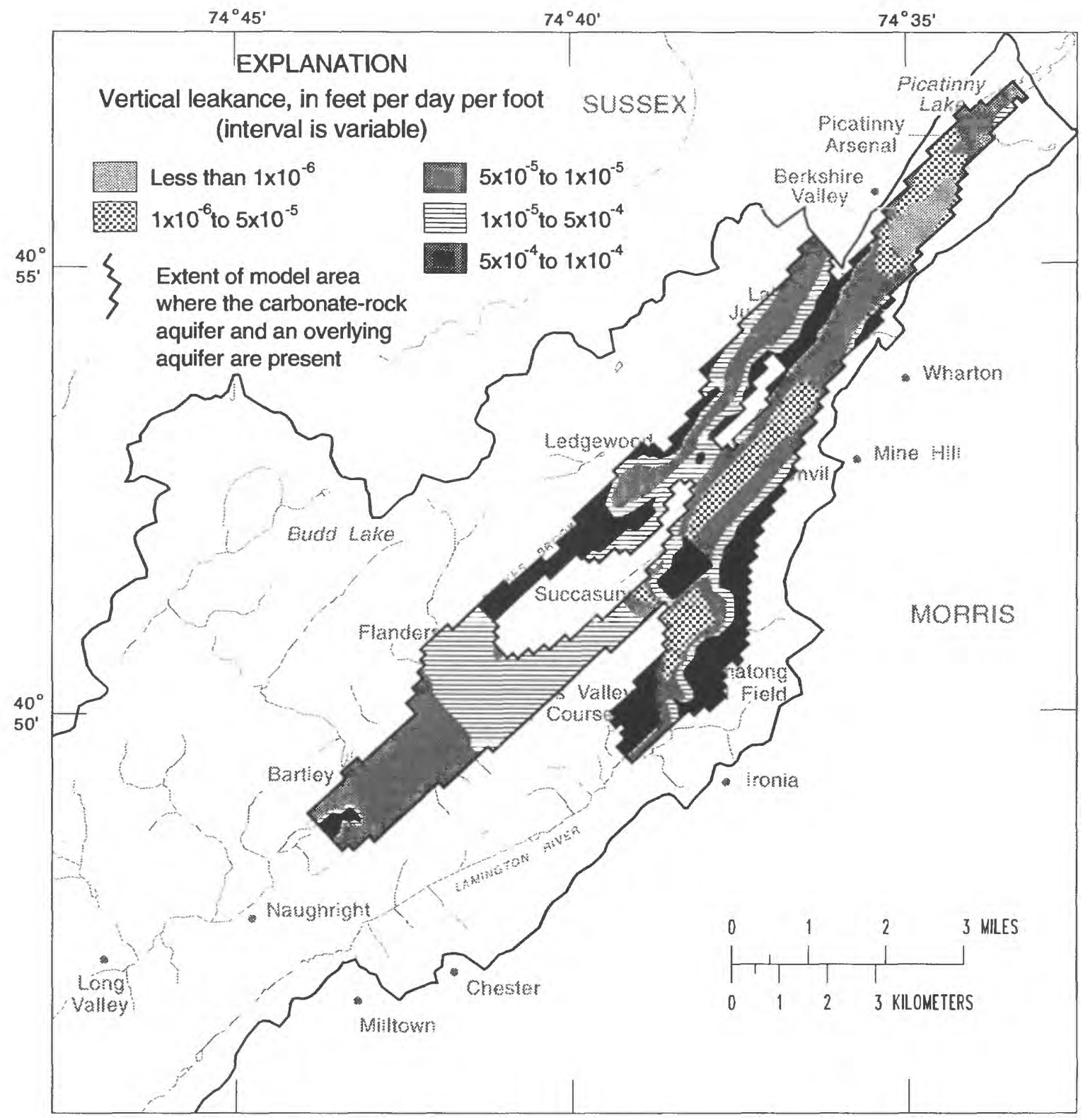

Figure 15. Distribution of vertical leakance between valley-fill aquifers and the carbonate-rock aquifer, as represented in the model. 
simulations of that area range from 22 to $432 \mathrm{ft} / \mathrm{d}$, and the values of storage coefficients used range from 0.015 to 0.3. Voronin (1991) simulated flow in the carbonate-rock aquifer at Picatinny Arsenal, New Jersey, by using a horizontal hydraulic conductivity of $10 \mathrm{ft} / \mathrm{d}$. This value was taken from Meisler (1976).

The yields of 93 wells tapping the carbonate-rock aquifer in the study area range from 1 to 2,000 $\mathrm{gal} / \mathrm{min}$. The specific capacities of 52 of these wells range from 0.03 to $232(\mathrm{gal} / \mathrm{min}) / \mathrm{ft}$. The wide range in these well- performance characteristics is the result of the nature of water-bearing zones in the carbonaterock aquifer. The laboratory-determined primary porosity of a core sample from the borehole for well $27-1123$ was 0.116 , and the primary permeability was $1.69 \times 10^{-6} \mathrm{ft} / \mathrm{d}$. The primary permeability is negligible, and ground water flows predominantly through interconnected secondary features such as fractures, joints, faults, and bedding planes, some of which have been enlarged by solution. The number, size, and degree of interconnection between openings determines the secondary permeability of the rock. Carbonate rock with high permeability is predominantly the result of extensive enlargement of interconnected secondary openings by solution. In some areas in the southern part of the study area, hard, unweathered, relatively massive dolomite is characterized by few water-producing fractures. Wells open to the rock in these areas have low yields, and bulk permeability is presumed to be very low. In other areas, the rock is softer, highly weathered, and densely fractured, with occasional large solution openings and, consequently, high permeabilities. Although solution openings can be numerous, they can also be filled with sediment, which reduces permeability.

Factors that control the degree of enlargement and interconnection of solution openings in carbonate rocks include (1) diagenetic processes affecting the potential for secondary porosity and permeability development; (2) geochemical factors affecting the susceptibility of the rock to dissolution; (3) lithologic and stratigraphic controls on the distribution of flow within evolving solution openings; (4) structural and tectonic factors controlling fracture size, density, and orientation; (5) hydrologic factors controlling evolutionary recharge and circulation of freshwater; and (6) geomorphic processes controlling infilling of existing solution openings. Brahana and others (1988) provide a detailed description of these factors. Although the evolution of secondary permeability of the carbonate- rock aquifer has not been investigated extensively, it is fairly certain that structural, tectonic, geochemical, hydrologic, and geomorphic processes have all played major roles in the development of water-bearing zones in this highly complex hydrogeologic unit.

The vertical distribution of water-bearing zones within the carbonate- rock aquifer was evaluated by examining drillers' logs of 13 boreholes. These boreholes encountered a total of 24 reported water-bearing zones. Only the water-bearing zones reported as voids or seams in drillers' logs were analyzed, and all of the wells probably encountered additional water- bearing zones that were either undetected or unreported by drillers. The 13 wells represent 2,522 feet of drilled rock, with well depths of up to 708 feet. The percentage of these water-bearing zones penetrated with depth is shown in figure 16 . The slope of the curve described by the percentages at 50 -foot increments deviates from the line that would indicate a uniform distribution. This deviation indicates that the number of water-bearing zones probably decreases with depth. On the basis of this small sample of wells, it is estimated that about half of the water-bearing zones are present within 300 feet of land surface, and the other half are present below this depth. Several water-bearing zones were reported at depths below 400 feet, indicating that ground water probably circulates to considerable depths within the carbonate rock. The presence of water-bearing zones at depth could be the result of solution-channel development trending along steeply dipping bedding planes.

On the basis of the highly variable lithologic and structural characteristics and the variability evident from well-performance data, the range of permeability of the carbonate-rock aquifer is expected to span several orders of magnitude. Despite the probability that predominantly conduit flow through a few discrete fractures dominates some local flow regimes, the carbonate-rock aquifer is conceptualized as acting as a single- layer, single-porosity, diffuse-flow continuum at the regional scale of the study. Subsequent interpretations follow this concept. 


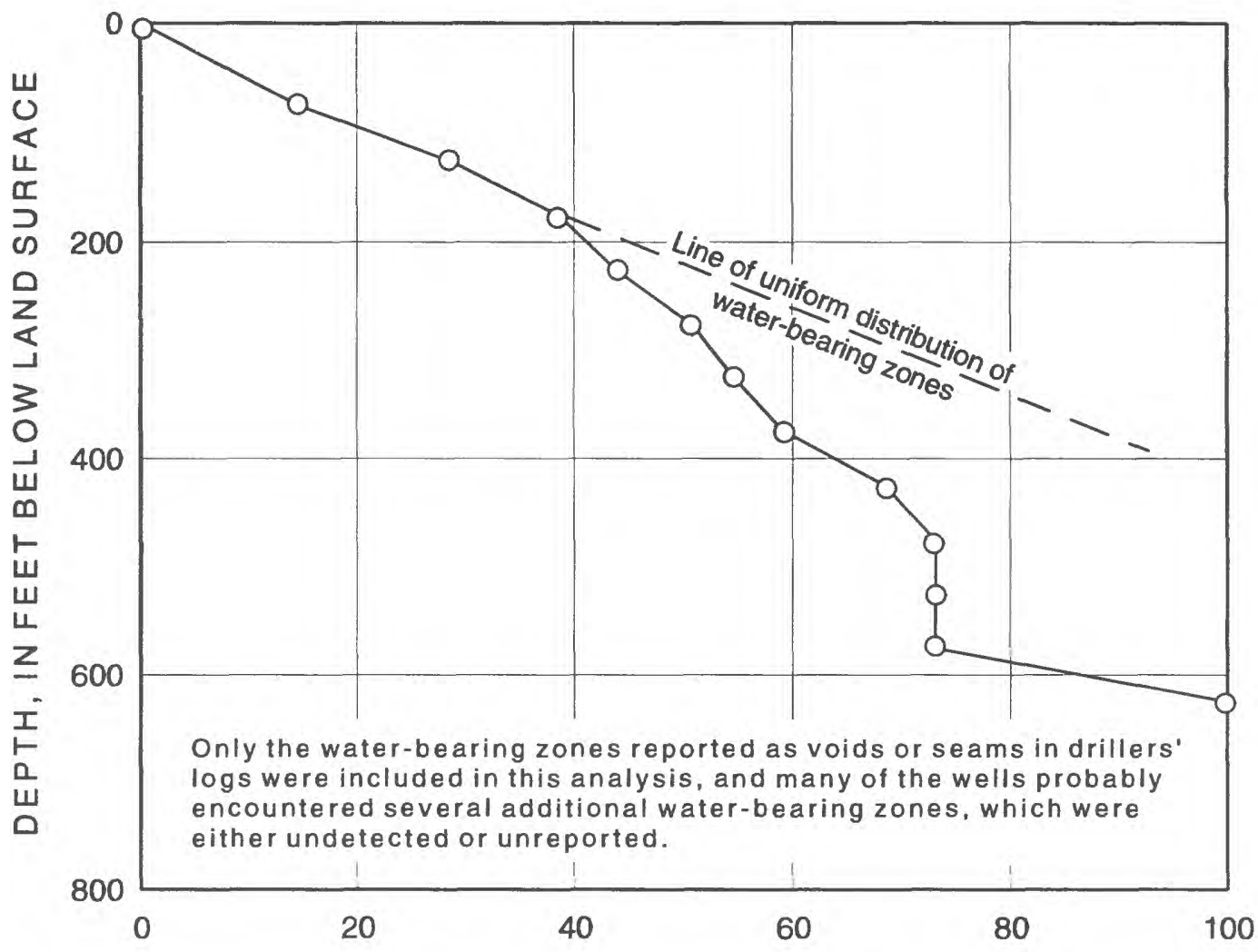

PERCENTAGE OF WATER-BEARING ZONES PENETRATED

Figure 16. Distribution of water-bearing zones with depth in the carbonate-rock aquifer in the New Jersey Highlands near Long Valley--24 reported water-bearing zones among 13 wells, representing 2,522 feet of drilled rock.

Data on well performance were examined to identify areas of relatively high and low permeability in the carbonate-rock aquifer. The performance of a well is related to the size and number of water-bearing zones encountered, and the degree of interconnection between zones. The bulk hydraulic conductivity of the material is related to these same characteristics; therefore, well performance is related to the hydraulic conductivity of the aquifer material near the open interval of the well. Because many factors other than hydraulic conductivity can affect the performance of a well, the nature of this relation is not always clear. Additional variables include well diameter, length of open interval, length of pumping period, proximity to hydraulic boundaries, and well-construction practices. Nevertheless, some relation between well performance and hydraulic conductivity can still be assumed to exist; therefore, examining the distribution of well-performance characteristics of many wells can provide an indication of the likely distribution of zones of contrasting permeabilities.

Among the variables listed above, the length of open interval would be expected to have a large effect on well performance. This variable can be controlled for easily, however, by dividing specific capacity by the length of the open interval to normalize the well-performance parameter being compared among wells. Specific capacity divided by length of the open interval was calculated and compared among 47 wells to provide an indication of the distribution of zones of relatively high and low permeability. The distribution of specific capacity divided by length of open interval (fig. 17) shows an area of consistently high values near Flanders, indicating a zone of relatively high permeability there. Although other scattered individual wells also show high values, many of these wells are near others with low values, illustrating the heterogeneity of the hydraulic conductivity of the rock at the local scale. Areas with zones of relatively low permeability are Picatinny Arsenal, Middle Valley, and the area between Califon and Hoffmans. 


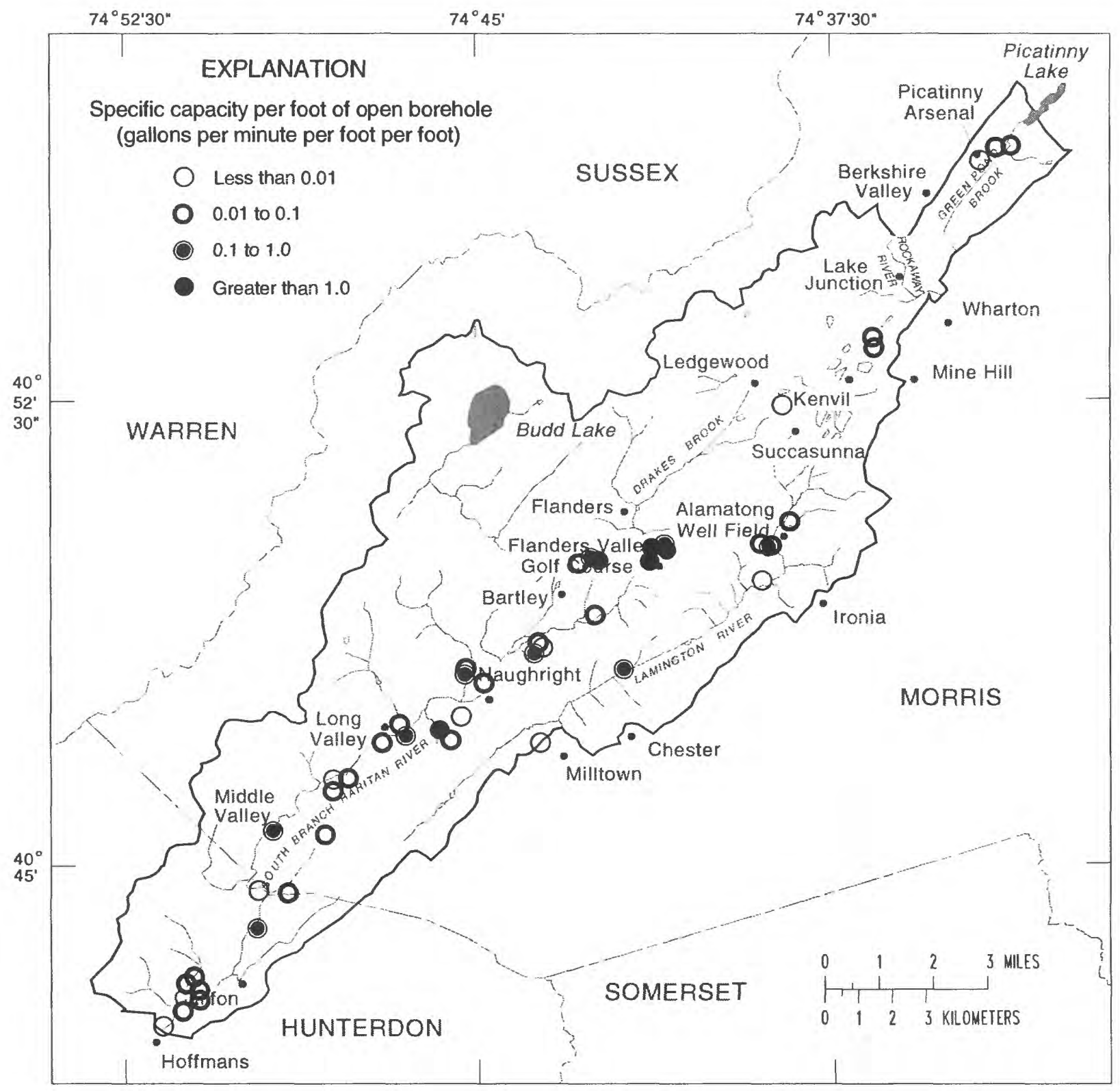

Figure 17. Specific capacity per unit length of open borehole of wells open to the carbonate-rock aquifer. 
Several aquifer tests were conducted on the carbonate-rock aquifer; five were conducted during this study and are discussed in detail later in this report, along with other analyses of transient flow. The results of these and other, previously conducted tests are summarized in table 2.

The distribution of hydraulic conductivity of the carbonate-rock aquifer as represented in the model is shown in figure 18. Values of hydraulic conductivity in the downvalley direction ranged from $0.1 \mathrm{ft} / \mathrm{d}$ where the carbonate-rock aquifer is overlain by Silurian and Devonian rocks to $864 \mathrm{ft} / \mathrm{d}$ along the center of the valley near Flanders. Aquifer anisotropy was represented by using cross-valley values that were lower than downvalley values by a factor of 7.5 , as determined from transient analysis of aquifer tests discussed later in this report.

\section{Other Rock Units}

The crystalline rocks of the upland areas in and near the study area are fractured and can yield ground water at rates sufficient for public supply or commercial use, although the yields are typically lower than yields of wells in valley-fill aquifers. In a study of ground-water availability in Morris County, Gill and Vecchioli (1965, p. 18-21) report that 50 of 79 large-diameter public supply, industrial, and commercial wells drawing ground water from fractured crystalline rocks yield $75 \mathrm{gal} / \mathrm{min}$ or less. They state further that wells open to fractured crystalline rocks that yield $100 \mathrm{gal} / \mathrm{min}$ or less are likely deriving water from the local fracture network, but that those yielding greater than $100 \mathrm{gal} / \mathrm{min}$ are likely deriving water from interception with major fault zones. These researchers state further that the capacity of the fractures to store and transmit water decreases with depth, that this capacity is variable both areally and vertically, and that large yields are not commonly obtained from wells cased below $300 \mathrm{ft}$. The crystalline rocks that form the uplands and underlie the valleys in the study area are considered to have water-bearing properties similar to those described by Gill and Vecchioli (1965).

\section{Water Quality and Geochemistry}

Water-quality samples were collected from 76 ground-water sites in the study area; these include 3 springs, 6 observation wells, and 16 wells owned by public and private water-supply companies. The remaining 51 sites are privately owned wells, both domestic and commercial, and noncommunity, nontransient wells belonging to schools and churches. The samples were collected to characterize the quality of water within ${ }^{1}$ the study area, and to supplement hydrologic data to gain an additional understanding of the ground-water-flow system. Of the sites at which water was sampled, 3 wells tap the Green Pond Conglomerate that is contained within the Paleozoic confining unit, 14 wells and 2 springs tap the Precambrian gneiss rock, 29 wells and 1 spring tap the carbonate-rock aquifer (Leithsville Formation), and 27 wells tap the valley-fill aquifers. In addition, surface water at six sites on Drakes Brook and the South Branch of the Raritan River was sampled for determination of base-flow chemistry. Locations of wells sampled are shown on plate 1a, and surface-water sampling sites are shown in figure 19.

The water-quality samples were analyzed for major ions, nutrients, and selected trace elements at the USGS National Water-Quality Laboratory (NWQL) in Lakewood, Colorado. Analytical methods used are described in Fishman and Friedman (1989) and Wershaw and others (1987). The quality of the data was assured by means of laboratory procedures in effect at the time of analysis and by evaluation with ionbalance methods; these practices are outlined by Friedman and Erdmann (1982). Results of analysis of duplicate samples showed good reproducibility, and results of analysis of equipment wash blanks indicated that sampling techniques did not affect the quality of the sample collected.

\footnotetext{
${ }^{1}$ Well 19-0252 taps the carbonate-rock aquifer but is located just outside the defined study area.
} 


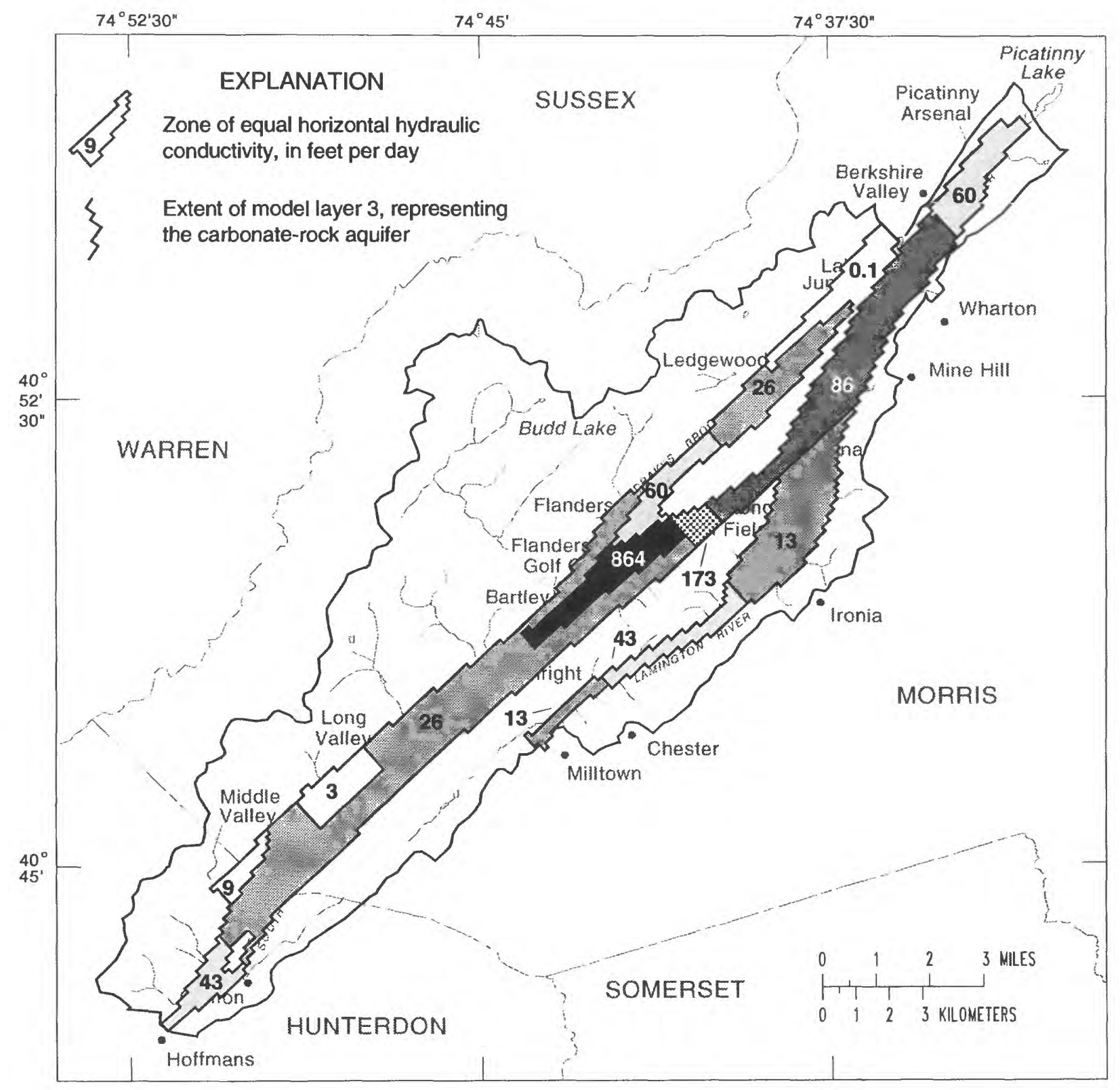

Figure 18. Extent of carbonate-rock aquifer and distribution of downvalley horizontal hydraulic conductivity, as represented in the model (model layer 3). (Cross-valley values are lower by a factor of 7.5 ) 


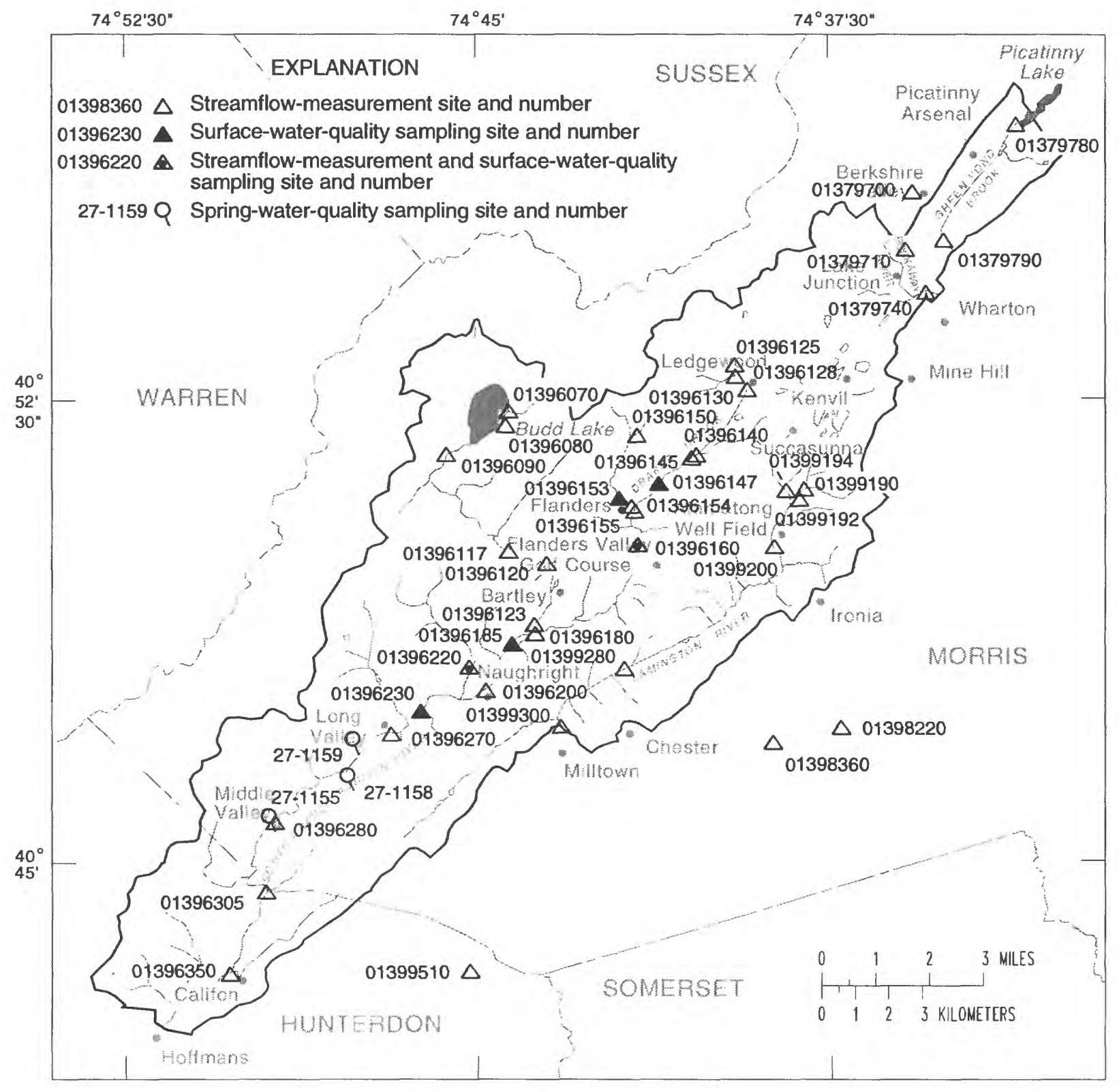

Figure 19. Streamflow-measurement and surface-water-quality sampling sites. 
A gas-chromatograph semiquantitative scan for volatile organic compounds (VOC's) was performed at the New Jersey District laboratory in Trenton (Kammer and Gibs, 1989); samples containing VOC's that exceeded New Jersey or U.S. Environmental Protection Agency MCL's ${ }^{2}$ (maximum contaminant levels) for drinking water were analyzed at the NWQL for verification. Laboratory blanks of analytefree water also were analyzed. Several ground- water samples were found to contain small concentrations of air-conditioning gases; because these gases were also detected in the blanks, these data are assumed to represent the presence of laboratory contaminants, and are not reported here.

Selected samples also were analyzed for isotopes of hydrogen, oxygen, and strontium. The isotope data were collected in order to determine relative ages of the water and to help detect mixing of waters from aquifers of different lithologies. Tritium (radioactive $3 \mathrm{H}$ ), deuterium $(2 \mathrm{H})$, and oxygen isotopes $\left({ }^{16} \mathrm{O}\right.$ and ${ }^{18} \mathrm{O}$ ) were analyzed at the USGS isotope laboratory in Reston, Virginia. The strontium-isotope ratio $\left({ }^{87} \mathrm{Sr} /{ }^{86} \mathrm{Sr}\right)$ was determined by mass spectrometry at the Isotope Geology laboratory of the USGS, Geologic Division. Precision and accuracy of the strontium-isotope data were assured by the routine analysis of a standard (EN-1) of known isotopic composition (Z.E. Peterman, U.S. Geological Survey, written commun., 1990).

\section{Quality of Ground Water in the Study Area}

Major-ion chemistry of water in the three main types of water-bearing units sampled (gneiss rock, carbonate rock, and glacial valley fill) indicated that some chemical signatures for water from each waterbearing unit are distinct. (The same was not true for water from the Green Pond Conglomerate water-bearing unit, where water chemistry varied substantially among the three samples collected.) Discriminant analysis on ranks with cross validation showed that water samples from the gneiss could be discriminated from water samples from the carbonate-rock aquifer on the basis of $\mathrm{pH}$, magnesium concentration, and silica concentration with 85 percent accuracy or greater. Temperature was the only characteristic that could be used to discriminate between water samples from the gneiss rock and water samples from the valley-fill aquifers, with an accuracy of 79 percent. Discriminant analysis on ranks for samples from the valley-fill and carbonate-rock aquifers indicated that water from these two aquifer types could not be distinguished on the basis of chemistry with even a moderate degree of accuracy.

The absence of a significant difference in chemistry between water samples from the carbonaterock aquifer and the valley-fill aquifers and attendant statistical misclassification of many water samples may be a result of mixing of water and of the heterogenous nature of the valley-fill aquifer materials. Mixing of water from the gneiss rock and valley-fill aquifers also may account for some of the lack of discrimination between waters from these water-bearing units, as may some variability in the composition of the gneiss. Further, the location at which the water sample is collected from any of the aquifers can affect the water chemistry. Ground water that is sampled in a recharge zone probably has had little opportunity to equilibrate with the aquifer lithology, but water that is sampled at the end of a long flow path is likely to be in equilibrium with its surroundings.

Similarities and differences in water chemistry are depicted graphically in figure 20, which shows Stiff diagrams for selected water samples from each of the three major water-bearing units. In the Stiff diagrams, the various "arms" represent major-ion concentrations in milliequivalents, with cations depicted on the left side of the diagram and anions on the right. The diagrams show, for example, that calcium and magnesium are dominant cations in the water from the carbonate-rock aquifer, but magnesium is less

${ }^{2}$ The MCL is the maximum concentration of a regulated constituent allowable in public drinking water. MCL's are enforceable drinking-water standards based on health criteria. These are set forth in the New Jersey primary drinking-water regulations (New Jersey Administrative Code, 1990a) and are the same as the MCL's established as part of the drinking-water regulations of the U.S. Environmental Protection Agency (Federal Register, 1989). Secondary maximum contaminant levels (SMCL's) are recommended maximum concentrations in public drinking water and are based on acceptable aesthetic and taste characteristics. 
MILLIEQUIVALENTS PER LITER

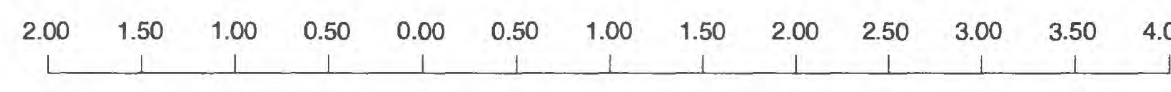

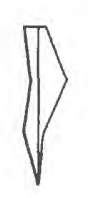
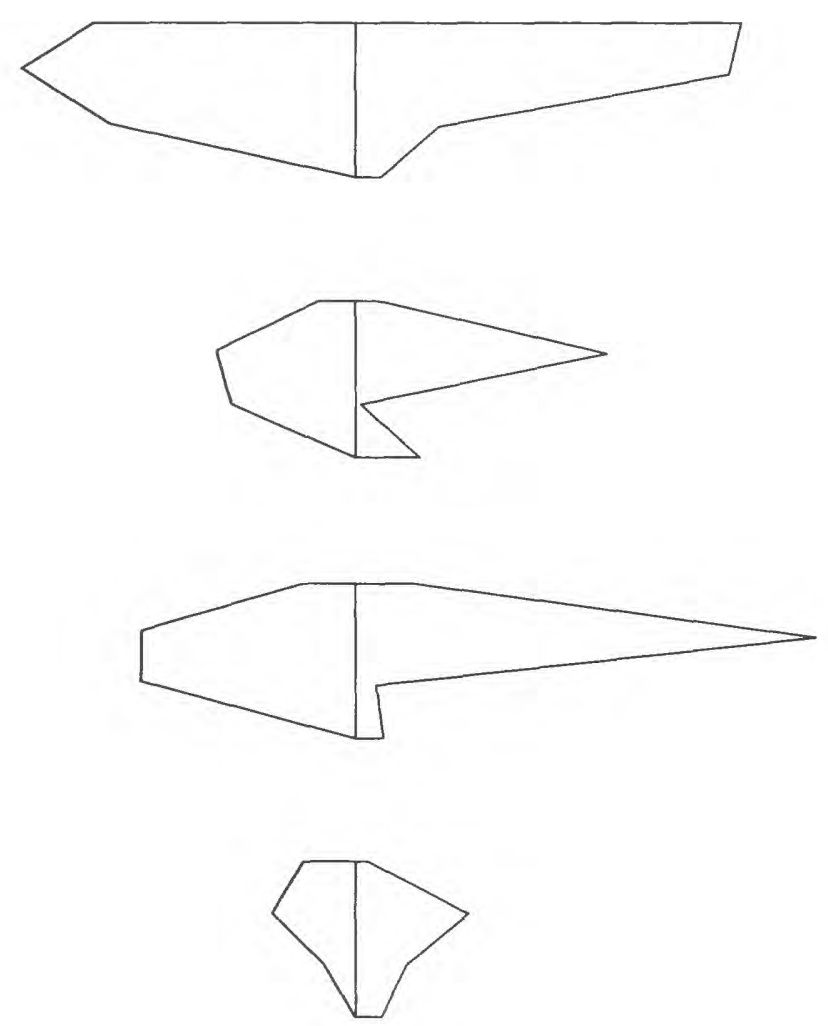

WATER-BEARING UNIT

AND WELL NUMBER

Valley fill

27-1176

Valley fill

27-1180

Valley fill

27-1169

Carbonate rock

27-1108

Gneissic rock

27-1154

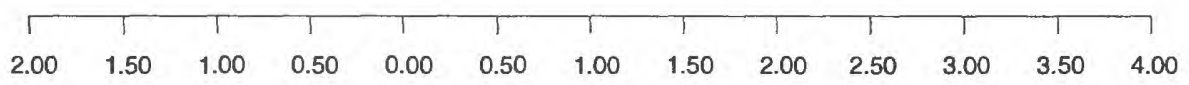

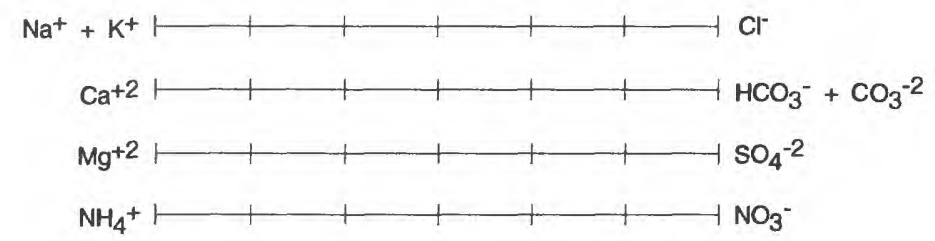

Figure 20. Selected Stiff diagrams for water from the valley-fill aquifers, the carbonate-rock aquifer, and the gneissic rock in the New Jersey Highlands study area. (Three diagrams are shown for water from the valley-fill aquifers, which display a more heterogeneous chemistry than water from either the carbonaterock aquifer or the gneissic rock) 
important in water from either the gneiss rock or the valley-fill aquifers. Sulfate is present in larger concentrations in water from the gneiss rock than in water from the carbonate-rock aquifer and in some samples from the valley-fill aquifers.

All water-bearing units yielded water in which the majority of trace elements were present at concentrations near or below the minimum reporting limit for each element. These elements include aluminum, arsenic, beryllium, cadmium, chromium, cobalt, copper, molybdenum, nickel, silver, and vanadium (app. 2). Lead concentrations were typically less than the minimum reporting limit of $10 \mu \mathrm{g} / \mathrm{L}$, although several wells yielded water with concentrations of 20 to $30 \mu \mathrm{g} / \mathrm{L}$. A statistical summary of selected properties and constituents is presented in table 4. Details of water chemistry for each of the three major water-bearing units and for the Green Pond Conglomerate are discussed in the following sections.

\section{Vallev-fill aquifers}

Water from the valley-fill aquifers varied considerably with respect to chemical constituents and properties. For example, specific conductance ranged from $20 \mu \mathrm{S} / \mathrm{cm}$, a value typical of precipitation in New Jersey (Lord and others, 1990), to $570 \mu \mathrm{S} / \mathrm{cm}$. A wide range of $\mathrm{pH}$ values also was observed, from 5.1, which is less than $1 \mathrm{pH}$ unit higher than the mean $\mathrm{pH}$ of precipitation measured in the northeastern United States (Turk, 1983), to 8.3, the approximate $\mathrm{pH}$ of water in equilibrium with atmospheric carbon dioxide and calcium carbonate rock.

Calcium and magnesium concentrations varied widely, ranging from 1.1 to $50 \mathrm{mg} / \mathrm{L}$ and 0.56 to $22 \mathrm{mg} / \mathrm{L}$, respectively. The range for sodium was similar to that for calcium (fig. 21). The range in chloride concentrations was greater than the range observed in water from the other two major water-bearing units studied (fig. 22), and was exceeded only by the range of concentrations observed in water from the conglomerate. A wide range of sulfate concentrations (from less than 0.2 to $33 \mathrm{mg} / \mathrm{L}$ ) also was observed. The ranges in silica, iron, and strontium concentrations were greater in samples from the valley-fill aquifers than in samples from the other water- bearing units.

None of the inorganic constituents in water from the valley-fill aquifers were present in concentrations that exceeded the MCL in effect at the time of sampling. Iron concentrations did exceed the secondary drinking-water regulation of $0.03 \mathrm{mg} / \mathrm{L}$ (New Jersey Administrative Code, 1990b) in one well, however. Although neither nitrate ${ }^{3}$ nor chloride concentrations exceeded MCL'S, water from three wells contained concentrations of nitrate greater than $3 \mathrm{mg} / \mathrm{L}$, and water from seven wells contained concentrations of chloride in excess of $30 \mathrm{mg} / \mathrm{L}$. On the basis of the remainder of the results of the water analyses, background concentrations of these constituents probably are less than $1 \mathrm{mg} / \mathrm{L}$ and $10 \mathrm{mg} / \mathrm{L}$, respectively. VOC's were detected in concentrations greater than the minimum reporting limits, but less than MCL's in water from five wells tapping the valley-fill aquifers; tetrachloroethylene was found to exceed the MCL in water from one well.

Because water in the upper valley-fill aquifer is under unconfined conditions, surficial inputs of various chemicals, such as fertilizers and road salt, can be expected to modify the background groundwater chemistry. Typically, effects of human activities are reflected in elevated specific- conductance values, which indicate the presence of greater concentrations of dissolved solids than the concentrations observed in unaffected water. The specific conductance of unaffected (background) water in the valley-fill aquifers probably is on the order of 100 to $200 \mu \mathrm{S} / \mathrm{cm}$ in many cases; however, the presence of a groundwater sample that contained as few solutes as precipitation (specific conductance of less than $50 \mu \mathrm{S} / \mathrm{cm}$ ) in the data set has skewed the statistical relations. This water sample (from well 27-1176) was similar in chemical composition to precipitation falling in the northeastern United States in most respects, except that the

${ }^{3}$ Nitrate was measured as nitrate plus nitrite, expressed as $\mathrm{mg} / \mathrm{L}$ of nitrogen. Because nitrite concentrations were at or below the reporting limit of $0.01 \mathrm{mg} / \mathrm{L}$ in virtually all samples, nitrate plus nitrite (as nitrogen) is referred to as nitrate throughout this report. 
Table 4.-Statistical summary of selected chemical characteristics of and constitucents in water samples from the valley-fill aguifers, carbonate-rock agulfar, and oneissic rock

[mg/L, milligrams per liter; $\mu \mathrm{g} / \mathrm{L}$, micrograms per liter; $\mu \mathrm{S} / \mathrm{cm}$, microsiemens per centimeter at 25 degrees Celsius]

\begin{tabular}{|c|c|c|c|}
\hline \multicolumn{4}{|c|}{ Valley-Fill Aquifers (27 samples) } \\
\hline Characteristic/constituent & Median & Maximum & Minimum \\
\hline $\mathrm{pH}$ & 7.0 & 8.3 & 5.1 \\
\hline Specific conductance $(\mu \mathrm{S} / \mathrm{cm})$ & 175 & 570 & 20 \\
\hline Dissolved oxygen (mg/L) & 6.4 & 12.9 & .07 \\
\hline Calcium, dissolved $(\mathrm{mg} / \mathrm{L})$ & 18 & 50 & 1.1 \\
\hline Magnesium, dissolved (mg/L) & 8.8 & 22 & .56 \\
\hline Sodium, dissolved ( $\mathrm{mg} / \mathrm{L}$ ) & 6.3 & 45 & 1.6 \\
\hline Potassium, dissolved (mg/L) & .70 & 1.8 & .30 \\
\hline Chloride, dissolved $(\mathrm{mg} / \mathrm{L}$ ) & 6.2 & 73 & 1.0 \\
\hline Sulfate, dissolved $(\mathrm{mg} / \mathrm{L})$ & 5.0 & 33 & $<.2$ \\
\hline Silica, dissolved (mg/L) & 17 & 29 & 6.4 \\
\hline Strontium, dissolved $(\mu \mathrm{g} / \mathrm{L})$ & 41 & 130 & 4.0 \\
\hline Alkalinity $(\mathrm{mg} / \mathrm{L} \mathrm{CaCO})_{3}$ & 70 & 171 & 5.7 \\
\hline Nitrate as $N(m g / L)$ & 1.40 & 6.10 & $<.10$ \\
\hline $\mathrm{Ca} / \mathrm{Mg}$ ratio & 2.3 & 5.9 & 1.6 \\
\hline \multicolumn{4}{|c|}{ Carbonate-Rock Aquifer (30 samples) } \\
\hline Characteristic/constituent & Median & Maximum & Minimum \\
\hline $\mathrm{pH}$ & 8.0 & 8.8 & 5.7 \\
\hline Specific conductance $(\mu \mathrm{S} / \mathrm{cm})$ & 208 & 692 & 119 \\
\hline Dissolved oxygen (mg/L) & 6.9 & 10.6 & .01 \\
\hline Calcium, dissolved $(\mathrm{mg} / \mathrm{L})$ & 20 & 60 & 6.1 \\
\hline Magnesium, dissolved (mg/L) & 11 & 35 & 1.8 \\
\hline Sodium, dissolved $(\mathrm{mg} / \mathrm{L})$ & 5.2 & 23 & 2.9 \\
\hline Potassium, dissolved $(\mathrm{mg} / \mathrm{L})$ & .90 & 11 & .40 \\
\hline Chloride, dissolved $(\mathrm{mg} / \mathrm{L})$ & 5.6 & 45 & 1.2 \\
\hline Sulfate, dissolved $(\mathrm{mg} / \mathrm{L})$ & 6.0 & 27 & 1.0 \\
\hline Silica, dissolved $(\mathrm{mg} / \mathrm{L})$ & 16 & 27 & 7.5 \\
\hline Strontium, dissolved $(\mu \mathrm{g} / \mathrm{L})$ & 32 & 400 & 17 \\
\hline Alkalinity $\left(\mathrm{mg} / \mathrm{L} \mathrm{CaCO}_{3}\right)$ & 82 & 255 & 26 \\
\hline Nitrate as $N(\mathrm{mg} / \mathrm{L})$ & 1.0 & 9.50 & $<.10$ \\
\hline $\mathrm{Ca} / \mathrm{Mg}$ ratio & 1.8 & 3.4 & 1.4 \\
\hline \multicolumn{4}{|c|}{ Gneissic Rock (16 samples) } \\
\hline Characteristic/constituent & Median & Maximum & Minimum \\
\hline $\mathrm{pH}$ & 6.6 & 8.6 & 5.8 \\
\hline Specific conductance $(\mu \mathrm{S} / \mathrm{cm})$ & 127.5 & 259 & 64 \\
\hline Dissolved oxygen $(\mathrm{mg} / \mathrm{L})$ & 7.4 & 10.2 & .09 \\
\hline Calcium, dissolved $(\mathrm{mg} / \mathrm{L})$ & 11.5 & 32 & 3.8 \\
\hline Magnesium, dissolved $(\mathrm{mg} / \mathrm{L})$ & 3.5 & 14 & 1.7 \\
\hline Sodium, dissolved $(\mathrm{mg} / \mathrm{L}$ ) & 6.0 & 23 & 3.2 \\
\hline Potassium, dissolved $(\mathrm{mg} / \mathrm{L})$ & .70 & 1.0 & .40 \\
\hline Chloride, dissolved $(\mathrm{mg} / \mathrm{L})$ & 3.9 & 24 & 1.4 \\
\hline Sulfate, dissolved $(\mathrm{mg} / \mathrm{L})$ & 13 & 40 & 2.4 \\
\hline Silica, dissolved ( $\mathrm{mg} / \mathrm{L})$ & 20.5 & 31 & 13 \\
\hline Strontium, dissolved $(\mu \mathrm{g} / \mathrm{L})$ & 37 & 110 & 11 \\
\hline Alkalinity $\left(\mathrm{mg} / \mathrm{L} \mathrm{CaCO}{ }_{3}\right)$ & 31.5 & 96 & 11 \\
\hline Nitrate as $N(m g / L)$ & .38 & 2.00 & $<.10$ \\
\hline $\mathrm{Ca} / \mathrm{Mg}$ ratio & 3.15 & 9.1 & 1.6 \\
\hline
\end{tabular}




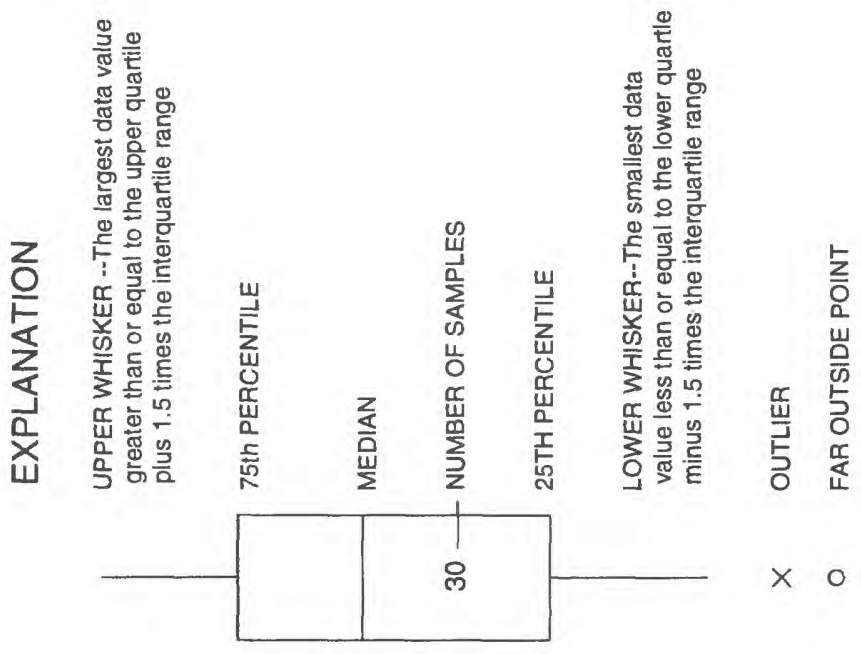

(5)
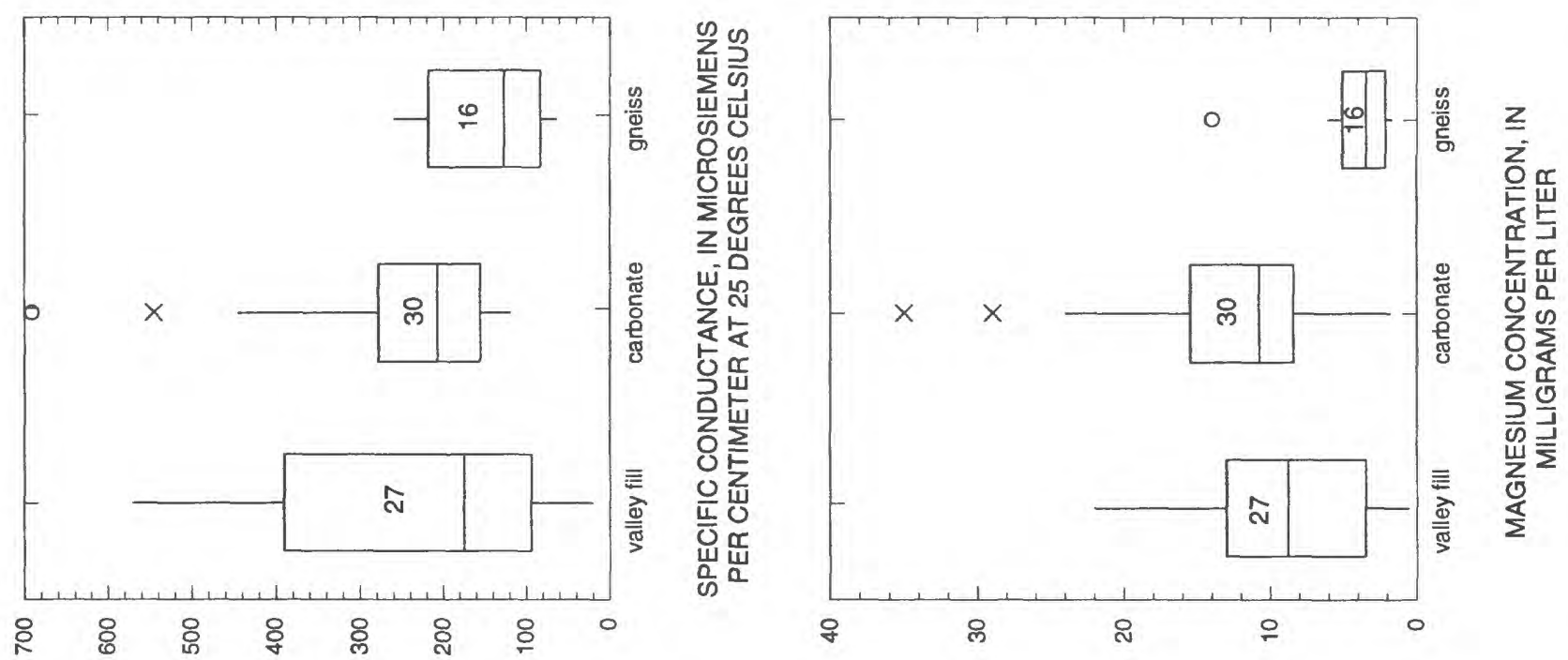

돌

迩

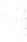
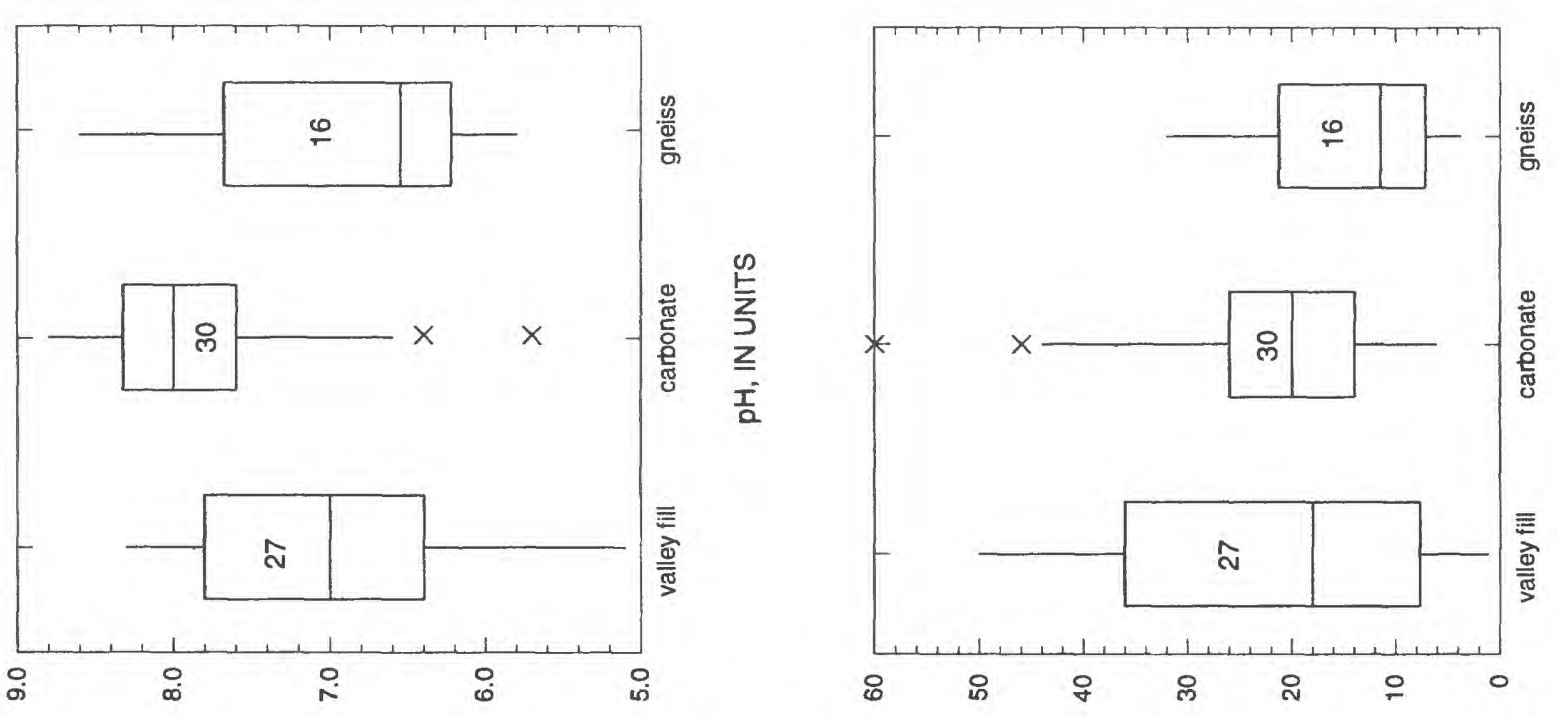

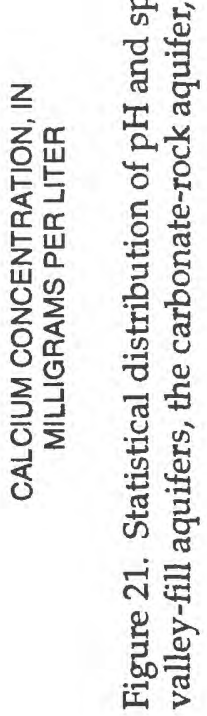




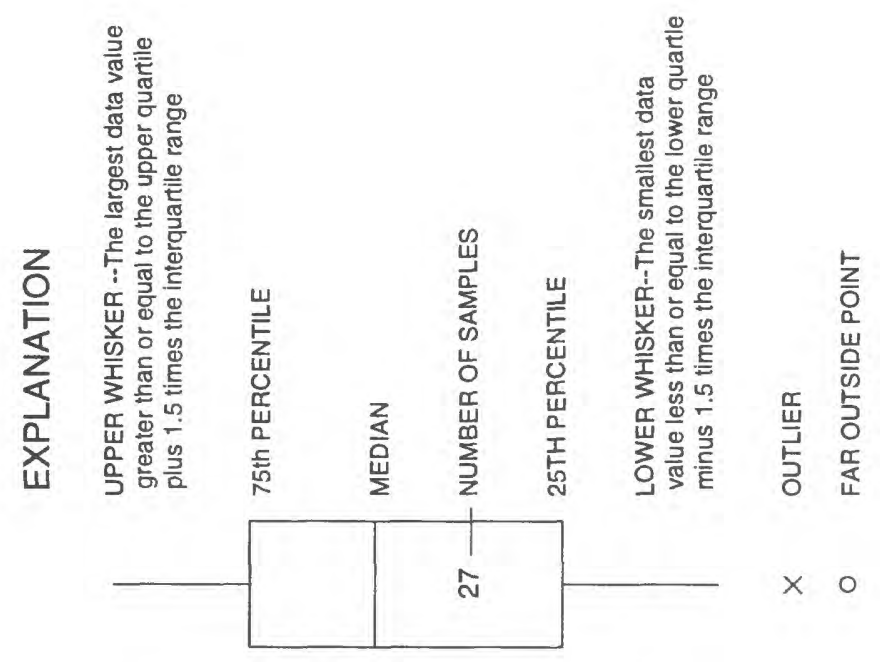

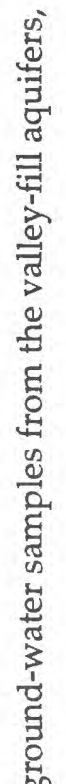
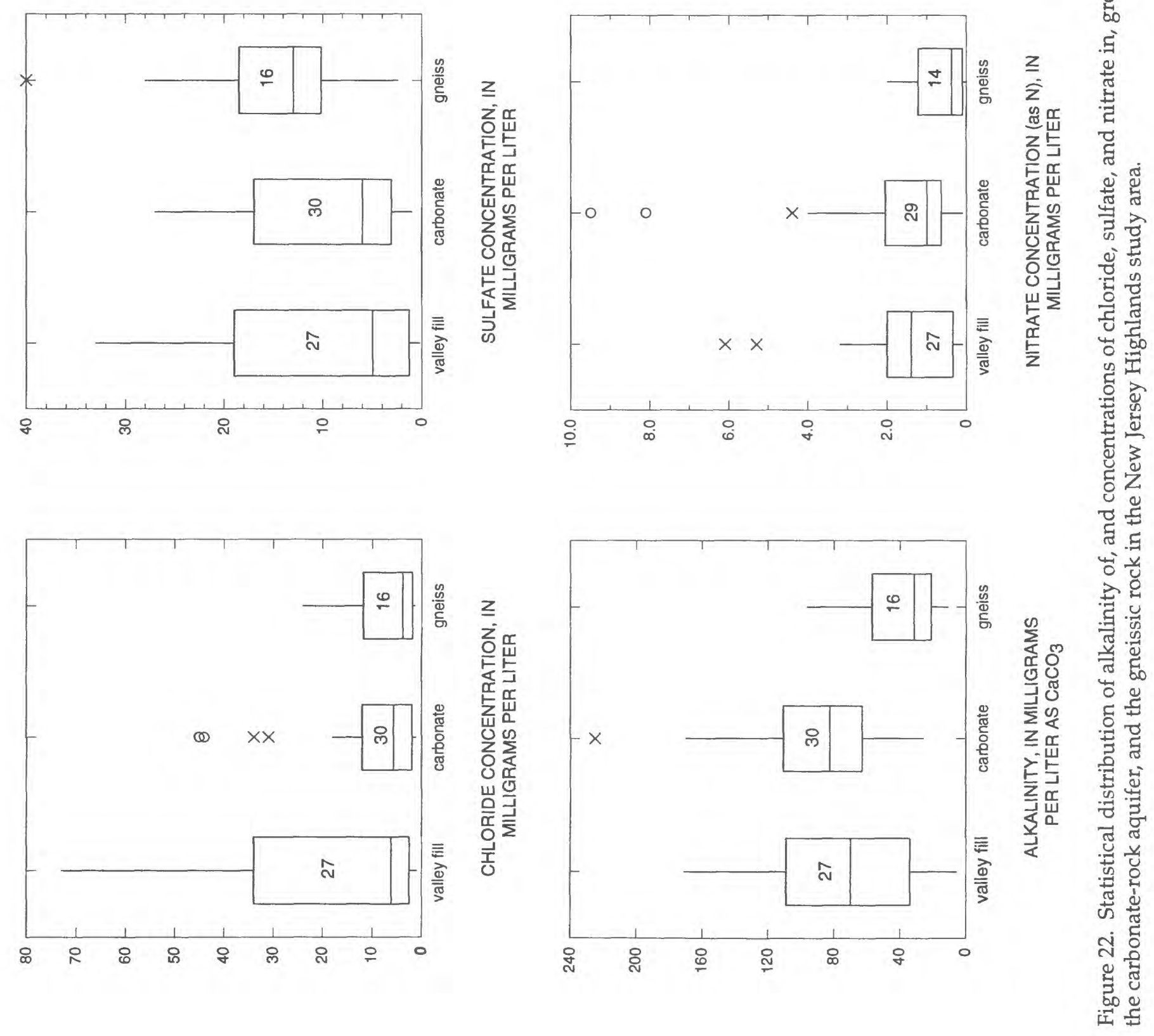
concentration of sulfate was less than the minimum reporting limit of $0.1 \mathrm{mg} / \mathrm{L}$, whereas precipitation in the northeastern United States typically contains sulfate in concentrations greater than $1 \mathrm{mg} / \mathrm{L}$. Nitrate concentrations in precipitation also can be greater than $1 \mathrm{mg} / \mathrm{L}$, but the nitrate concentration in the ground water sample was less than $1 \mathrm{mg} / \mathrm{L}$. Conversely, the alkalinity of the ground-water sample was greater than is typical of precipitation. Biological activity may have removed sulfate and nitrate from the incident precipitation and increased the alkalinity of this water sample.

Although analytical results for one sample indicate little difference between the chemistry of the precipitation and that of the ground water, results of analyses of other water samples indicate that interaction between ground water and aquifer materials has occurred. In particular, well-water samples with $\mathrm{pH}$ greater than 7 and concentrations of calcium and magnesium greater than $10 \mathrm{mg} / \mathrm{L}$ are indicative of probable interactions between carbonate-rock aquifer materials and ground water. The water samples whose chemistry resembles that of carbonate-rock water are from wells that tap water near the interface between the valley-fill and carbonate-rock aquifers or that are located in areas where ground-water flow has been determined to have an upward component.

\section{Corbonate-Rock Aquifer}

On the basis of analyses of samples collected from 29 wells and 1 spring during the present study, the chemistry of water in the carbonate-rock aquifer is more consistent than that of water in the valley-fill aquifers. Specific conductance generally was higher in water from the carbonate-rock aquifer than in water from the valley-fill aquifers, although the upper end of the range for water from the valley-fill aquifers overlaps part of the upper end of the range for water from the carbonate-rock aquifer. The $\mathrm{pH}$ of water from the carbonate-rock aquifer tended to be higher than the $\mathrm{pH}$ of water from the valley-fill aquifers, but some values overlap. Calcium, magnesium, and bicarbonate ions tended to be dominant ions, whereas sodium, chloride, and sulfate ions generally accounted for substantially less of the charge balance. In several samples, nitrate accounted for more of the anion charge than did sulfate.

Although nitrate concentrations did not exceed the New Jersey primary drinking-water regulation of $10 \mathrm{mg} / \mathrm{L}$ in any water samples collected during the study, water from four wells tapping the carbonaterock aquifer contained nitrate concentrations greater than $3 \mathrm{mg} / \mathrm{L}$. VOC's were detected in amounts greater than the minimum reporting limit in four water samples; only one well yielded water containing an organic compound (identified as 1,1-dichloroethylene) that exceeded the State's primary drinking-water regulation.

\section{Gneissic rock}

The range of $\mathrm{pH}$ values in water from wells tapping the gneiss was similar to those observed in samples from the valley-fill and carbonate-rock aquifers; however, water from the gneiss rock commonly was more acidic than water from the other aquifers. The median $\mathrm{pH}$ of water from the gneiss rock was 6.6; medians for water from the valley-fill and carbonate-rock aquifers were 7.0 and 8.0, respectively. Alkalinity typically was lower in water from the gneiss rock, and the range of alkalinity values was substantially smaller than the ranges for the valley-fill and carbonate-rock aquifers.

Overall, magnesium concentrations tended to be smaller in water from the gneiss than in water from the valley-fill and carbonate-rock aquifers; silica concentrations tended to be larger. Chloride and nitrate concentrations generally were smaller in water from the gneiss rock and sulfate concentrations typically were larger than in water from the valley-fill and carbonate-rock aquifers.

Of the trace elements (app. 2), barium concentrations were smaller in water from the gneiss than in water from the valley-fill and carbonate-rock aquifers. Zinc concentrations exceeded $100 \mu \mathrm{g} / \mathrm{L}$ in water from five wells; this constituent was present in concentrations less than $50 \mu \mathrm{g} / \mathrm{L}$ in water from the majority of wells tapping the valley-fill and carbonate-rock aquifers. Only one well tapping the gneiss rock yielded water in which a VOC (chloroform) was detected. 


\section{Conglomerate rock}

Because only three water samples were collected from the Green Pond Conglomerate, statistical characterization of the ground-water chemistry is very limited. With this in mind, comparisons are made below. Substantial variability in water chemistry was noted among the three samples; however, the $\mathrm{pH}$ and alkalinity of all three samples were low (ranging from 5.2 to 5.7 and from 2 to $21 \mathrm{mg} / \mathrm{L}$ as calcium carbonate, respectively). Elevated concentrations of sodium and chloride in one well-water sample ( 65 and $100 \mathrm{mg} / \mathrm{L}$, respectively) relative to those in the other two indicates that the subject well most likely has been exposed to a source of sodium and chloride related to human activities. The specific conductance of water from that well also was elevated $(415 \mu \mathrm{S} / \mathrm{cm})$ relative to that of water from the other two wells.

One of the two other wells tapping the conglomerate rock yielded water with a specific conductance of $29 \mu \mathrm{S} / \mathrm{cm}$; this value is similar to the specific conductance of precipitation. The sulfate concentration in water from this well however, unlike that in precipitation, was less than the minimum reporting limit of $0.1 \mathrm{mg} / \mathrm{L}$. The water from this second well bore a chemical resemblance to water from a well tapping the upper valley-fill aquifer, in which sulfate and nitrate concentrations also were smaller than would be anticipated in precipitation. In both cases, it appears that either the relative absence of reactive minerals in the aquifer materials or a short residence time for the water sampled, or both, has resulted in water that is, for the most part, chemically similar to precipitation. The reduction in sulfate and nitrate concentrations, coupled with the concommitant increase in alkalinity over typical values of these constituents in precipitation, probably is the result of biological activity in the soil zones through which the precipitation passed.

No inorganic or organic constituents in the water samples from wells tapping the conglomerate rock exceeded New Jersey drinking-water regulations in effect at the time of sampling. The concentration of nitrate in water from one well was $8.3 \mathrm{mg} / \mathrm{L}$ as N, and the concentration of lead was $30 \mu \mathrm{g} / \mathrm{L}$. In the same well, $2.3 \mu \mathrm{g} / \mathrm{L}$ of chloroform was detected; in a subsequent analysis of this water by the NWQL, traces of two other VOC's also were detected (dichloroethane and trichloroethane).

\section{Quality of Water in Streams of the Study Area}

Of the six surface-water samples collected, two were taken from Drakes Brook, one was from a tributary to Drakes Brook, two were from the South Branch of the Raritan River, and one was from a tributary to the latter river. The two tributaries drain Precambrian gneiss terrain; the main stems of the brook and river drain carbonate-rock terrain or carbonate-rock terrain overlain by glacial sediments. Samples were collected 1 and 2 days after a brief period of light precipitation; the streams were judged to be under baseflow conditions at the time of sampling.

The chemistry of the six surface-water samples indicates the effect of the different lithologies on surface-water quality. The chemistry of the samples from the two tributaries draining the gneiss terrain was, overall, different from that of the mainstem streams draining the glacial and carbonate-rock terrains. The specific conductance of the samples from the tributaries was lower $(140$ and $200 \mu \mathrm{S} / \mathrm{cm})$ than the specific conductance of the samples from the mainstem streams, which ranged from 233 to $442 \mu \mathrm{S} / \mathrm{cm}$. Although the $\mathrm{pH}$ of water from the gneiss rock typically was less than 7.0, the $\mathrm{pH}$ of the two samples from the tributaries was 7.8 to 7.9. These values are, however, lower than the $\mathrm{pH}$ of the samples from the mainstem streams draining glacial and carbonate-rock terrains, which ranged from 8.0 to 8.5. Further, alkalinity in both tributary samples was less than $35 \mathrm{mg} / \mathrm{L}$ as calcium carbonate, whereas the alkalinity of the mainstem surface-water samples ranged from 57 to $89 \mathrm{mg} / \mathrm{L}$ as calcium carbonate. In addition, concentrations of dissolved organic carbon and iron were lower in the tributary samples than in the mainstem samples. The calcium-to-magnesium ratio (CMR) also can be used to distinguish between surface water draining the gneiss terrain and surface water draining the glacial and carbonate-rock terrains. The CMR for groundwater samples from the gneiss rock typically was greater than 2.5 ; the CMR of samples from the carbonaterock aquifer typically was about 2.0. Similar CMR's were observed for the surface-water samples. 


\section{Age of Ground Water in the Study Area}

Tritium, a short-lived radioactive isotope of hydrogen (half-life of 12.26 years), is measured in water samples in order to trace hydrologic processes and, in some cases, to give some indication of the age of the water. The isotope is produced naturally, as cosmic-ray neutrons interact with atmospheric nitrogen to produce tritium $\left({ }^{3} \mathrm{H}\right)$ and carbon $\left({ }^{12} \mathrm{C}\right)$, but also can be produced by manmade nuclear reactions (Faure, 1986). In the northern hemisphere, the concentration of tritium in precipitation prior to 1952 was about 5 tritium units (TU) (Mazor, 1991), but increased substantially as the result of atmospheric thermonuclear weapons testing, which began in 1952 (Faure, 1986; Mazor, 1991). Atmospheric tritium reached a peak in 1963, when such testing was banned. Since that time, tritium levels have declined steadily (Mazor, 1991). Ground water that entered an aquifer as pre-1952 precipitation contains virtually no tritium $(<0.5 \mathrm{TU})$, whereas ground water with a tritium concentration greater than $10 \mathrm{TU}$ is considered to have a post-1952 age (Mazor, 1991). Because of mixing within an aquifer, age dating by means of tritium analysis is at best semiquantitative but is still informative.

Tritium concentrations were measured in 28 water samples from the study area-- 5 from wells tapping the gneiss rock, 1 from a spring emanating from the gneiss, 9 from wells tapping the carbonate-rock aquifer, and 13 from wells tapping the valley-fill aquifers. The analytical values are reported by the laboratory in picocuries per liter, and have been converted to TU by the formula $1 \mathrm{TU}=3.2 \mathrm{pCi} / \mathrm{L}$. The minimum reporting limit for the analytical method used is $5.7 \mathrm{pCi} / \mathrm{L}$, which is approximately $1.8 \mathrm{TU}$. Figure 23 shows the locations of the sampling sites and the analytical results in tritium units (TU).

Tritium values, in TU, range from less than the reporting limit ( $5.7 \mathrm{pCi} / \mathrm{L}$ or approximately $1.8 \mathrm{TU}$ ) to $32 \mathrm{TU}$ (fig. 23). Most of the values are greater than 14.6 TU. Although these data do not permit a quantitative assessment of the age of the water, they do give an indication of approximate age.

Two points need to be considered when interpreting these data. First, the length of the open hole in wells tapping the carbonate-rock aquifer and in wells tapping the gneiss rock ranges from 11 to nearly 500 feet, and, of the wells sampled, the open intervals of most are greater than 100 feet long. Therefore, the water drawn from these wells represents an integration of ages (and chemical constituents) collected over the entire open interval. The sampled observation wells installed for this study (wells 27-1123, 27-1125, and 27-1126) are exceptions because they are cased over most of the depth of the hole.

The second point that makes quantitative interpretation of tritium- concentration data difficult is that the tritium values for precipitation in the study area for the period from 1953 to 1993 are unknown. In 1963 , when the concentration of tritium in the atmosphere was at its peak, a weather station in Hatteras, North Carolina, reported data that average to about 1,000 TU for that year (Mazor, 1991). Because tritium concentrations in the northern hemisphere typically increase with latitude, tritium concentrations in precipitation from 1963 could have been 1,500 TU or higher in the study area, but could have been only several hundred TU a few years earlier. The value of $32 \mathrm{TU}$, therefore, could represent tritium from before the time of peak concentrations that has decayed to approximately 10 percent of its initial concentration during the intervening 30 or more years. Because concentrations of tritium in the atmosphere declined steadily after 1963 , values of about 10 to $30 \mathrm{TU}$ in water from wells in the study area also could represent water that entered the aquifer after 1963. Such water would contain concentrations of tritium less than peak values, but this tritium would have had less time for radioactive decay than tritium in pre-1963 water. Groundwater samples containing relatively low tritium concentrations also could represent a mixture of water with a bomb-era tritium signature with older water bearing a pre-bomb-era tritium signature.

Three wells yielded water containing concentrations of tritium less than the reporting limit $(<1.8$ TU); these (all USGS observation wells) are tapping water with an average age that is apparently greater than the ages of other waters sampled in this study. In the Black River Wildlife Management Area (pl. 1a), one well (27-1164) yielding water with a tritium concentration less than $1.8 \mathrm{TU}$ is finished in glacial materials that are hydraulically tight, whereas the accompanying deeper well (27-1126), finished in the more hydraulically conductive carbonate-rock aquifer, yielded water that, with a tritium concentration of 5.7 TU, is clearly younger. Farther northeast in the Wildlife Management area, well 27-1125 taps water in the 


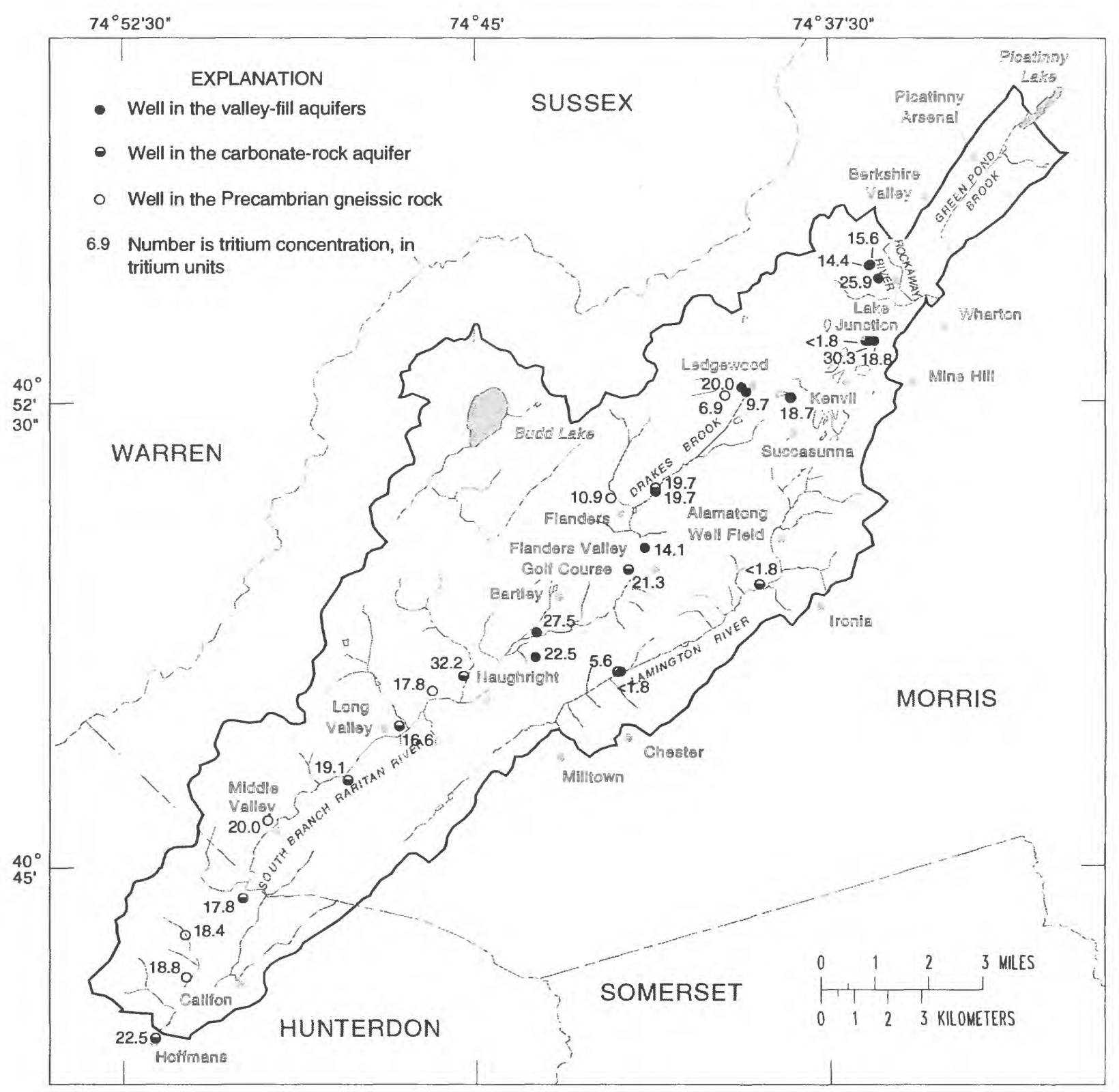

Figure 23. Concentrations of tritium in ground water in the study area. 
carbonate-rock aquifer that contains concentrations of tritium less than the reporting limit. The only other well found to tap water with tritium less than the reporting limit is the USGS observation well 27-1123, in Kenvil. This well may be intercepting water that is moving southwestward from Picatinny Arsenal (pl. 1a); the relatively greater age of this water probably reflects a long flow path. Because the water samples were not analyzed with the most sensitive method for tritium, it is not known whether a concentration less than $1.8 \mathrm{TU}$ represents pre-1952 water (containing $<0.5 \mathrm{TU}$ ), or water that was not recharged during the peak years of atmospheric bomb testing.

Although the tritium-concentration data can be interpreted only semiquantitatively, of the wells sampled for tritium analysis, most apparently tap water that is either slightly older than peak bomb-era age or younger than peak bomb-era age. Because no tritium concentrations appear to be high enough to represent peak bomb-era age water, the more plausible interpretation is that much of the ground water sampled is younger than 30 years; this indicates the presence of generally good hydraulic connections between unconfined and confined water-bearing units in the study area.

\section{Geochemical Relations Between Water Chemistry and Lithology}

Given the geologic complexity of the study area, it might be expected that ground-water chemistry would reflect some of that complexity, particularly as water in chemical equilibrium with the mineralogy of one aquifer moves into another aquifer and there has to achieve a new chemical equilibrium. Further, because water from one aquifer can mix with water from another, it is difficult to determine all the processes that may contribute to the observed ground-water chemistry.

\section{Interpretation of the calcium to magnesium ratio of around water}

The CMR in ground water from the three major water-bearing units (valley fill, carbonate rock, and gneiss rock) has proved to be useful in interpreting differences in water chemistry of samples among units (fig. 24). The median value of the CMR for water samples from the valley-fill aquifers was 2.3 (table 4); although the values ranged from 1.6 to 5.9 for the samples collected, the CMR for 19 of 27 samples was between 2.0 and 2.5. Judging from the results of analyses of precipitation samples collected and analyzed elsewhere in New Jersey, the CMR for precipitation is highly variable; therefore, the relatively constant value of the CMR for valley-fill-aquifer water indicates that meteoric waters recharging the valley-fill aquifers probably have approached a chemical equilibrium with the aquifer materials with respect to calcium and magnesium. The lowest CMR values were for water samples from wells tapping outliers of glacial materials, and may represent some mixing with water from the carbonate-rock aquifer.

Water in chemical equilibrium with the carbonate-rock aquifer materials (primarily dolomite) could be expected to have a CMR similar to that of the mineral dolomite, the chemical formula of which contains one mole each of calcium and magnesium. The weight ratio of these elements is 1.65, and the weight ratio of calcium to magnesium (in milligrams) in water from the carbonate-rock aquifer in the central part of the buried valley is also between 1.6 and 1.7, indicating that the CMR for the ground water in the center of the valley reflects the CMR of the rock through which it passes. Higher values of the CMR are found in water from wells located near the gneisses that flank the valley or wells that tap the carbonate-rock aquifer where it is overlain by substantial thicknesses of glacial materials. Thus, a CMR higher than 1.7 in samples of water from the carbonate-rock aquifer may signal mixing with water from either the overlying valley-fill aquifers or the flanking gneiss rock which typically had a CMR greater than 2.0.

The CMR for water from the gneiss rock is variable, but was greater than 2.0 in all but one sample. The values for the samples collected during this study ranged from 1.6 to 9.1, with a median of 3.1 , which is substantially greater than the CMR for water from either the valley-fill or the carbonate-rock aquifers. The CMR for water in equilibrium with the gneiss rock could be expected to vary, because the composition of the gneiss varies substantially. Available geologic data indicate that most of the Precambrian rocks in and surrounding the study area are leucogneisses which contain calcic minerals, such as plagioclase feld- 


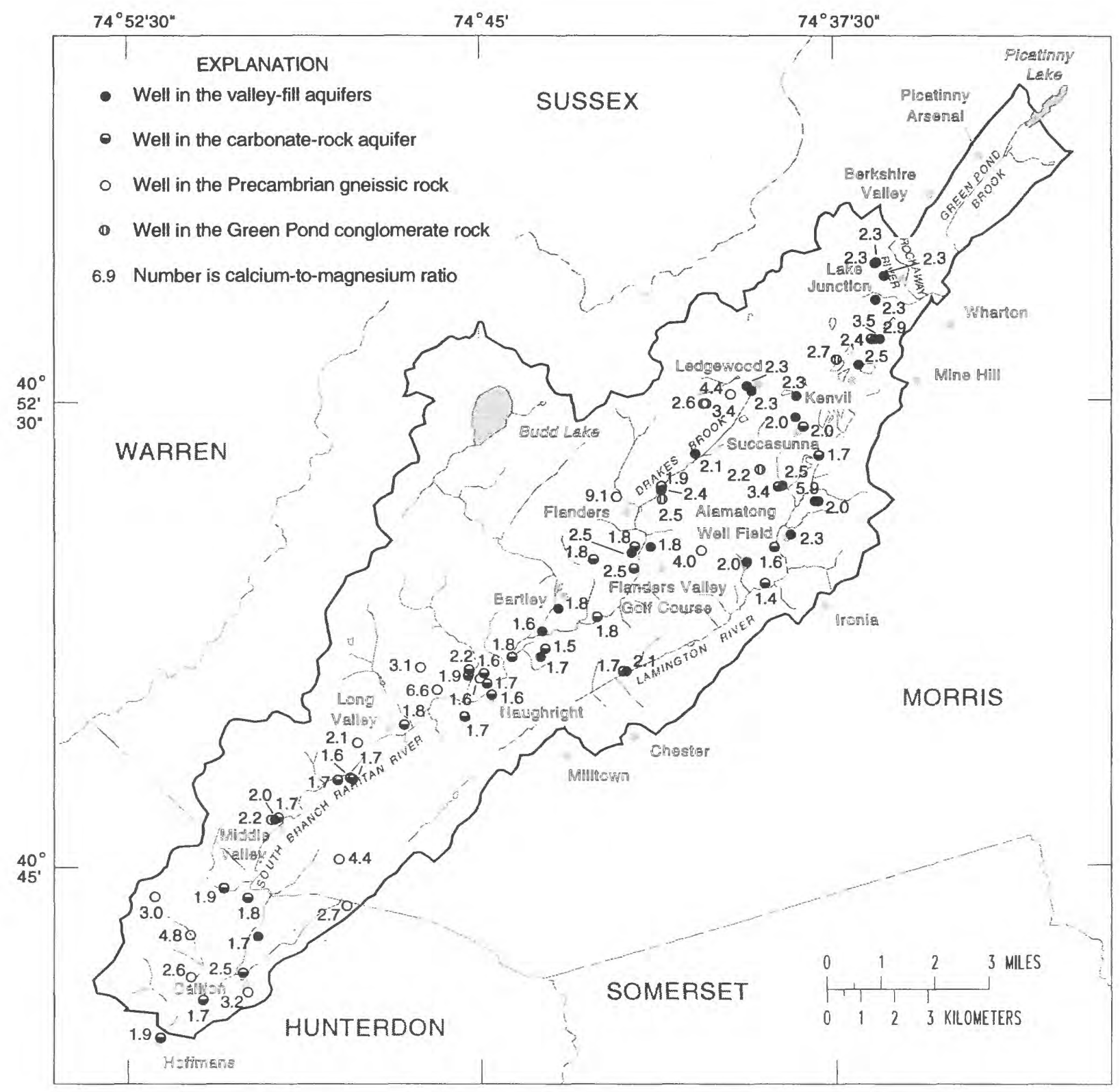

Figure 24. Ratio of calcium to magnesium in ground water from wells in the study area. 
spar and epidote, but which contain relatively few magnesium-bearing minerals. In isolated instances, mafic rock, usually a pyroxenite, could include minerals with a larger proportion of magnesium than the leucogneisses. The variability of the gneiss mineralogy probably explains much of the variability of the CMR in the water from the gneiss rock. The low value of 1.6 is typical of water from the carbonate-rock aquifer, and appears as an anomaly when compared with CMR values for water samples from the rest of the gneiss rock. This particular sample is from a well open to the gneiss rock that is located in the center of the valley near Naughright (well 27-1162). There, the gneiss rises beneath the dolomite to about 60 feet from land surface (see pl. 1d). Because water from this well is chemically similar to water from nearby wells in the carbonate-rock aquifer (relatively high alkalinity, low CMR, and low silica concentration), it appears either that water from the carbonate-rock aquifer moves into the gneissic rock in this area or that the well (27-1162) draws water from the carbonate rock when pumped.

\section{Interoretation of the strontium-isotope ratio of around water}

Two isotopes of strontium $\left({ }^{87} \mathrm{Sr}\right.$ and ${ }^{86} \mathrm{Sr}$ ) were measured during this study with the intent of using the ratio of these isotopes to detect mixing of waters among the major water-bearing units. The ratio of ${ }^{87} \mathrm{Sr}$ to ${ }^{86} \mathrm{Sr}$ or strontium-isotope ratio (SIR) has proved useful in identifying mixing of surface water in tributaries and mainstem rivers flowing through differing lithologies (Curtis and Stueber, 1973; Stueber and others, 1975; Fisher and Stueber, 1976). If the isotopes in the water are in equilibrium with those in the aquifer materials in which it resides, the value of the ratio depends on the age and mineralogy of the aquifer materials. ${ }^{87} \mathrm{Sr}$ is derived from radioactive decay of ${ }^{87} \mathrm{Rb}$ (rubidium), whereas ${ }^{86} \mathrm{Sr}$ is simply a relatively common stable isotope of strontium. Old (in this case, Precambrian) rocks containing relatively large amounts of rubidium, such as the leucogneisses, are likely to have a large SIR relative to rocks containing little rubidium but much strontium, such as dolomites. Water in equilibrium with these two rock types would then be expected to have ratios that reflect the isotopic composition of the host rock, and mixing of these two types of waters could be seen in an intermediate value of the SIR.

The SIR data (see app. 3) obtained during this study show that the SIR's of leucogneiss rock samples were high (ranging from 0.72282 to 0.79053 ) compared to that of a sample of mafic gneiss $(0.70481)$. Half the water samples collected from the gneiss rock had a relatively high SIR ( 0.71218 to 0.72716$)$; the other half had a low SIR ( 0.70859 to 0.70981$)$ indicative of water in equilibrium with mafic gneiss. Two dolomite samples from the Leithsville Formation yielded SIR's of 0.71028 and 0.70998 . The SIR's of water samples from the carbonate-rock aquifer vary less $(0.70965$ to 0.71993$)$ than those from water samples from the gneiss rock, and are fairly consistent with SIR's that would indicate equilibrium with the dolomite. No SIR's were established for the glacial valley-fill materials, but the SIR's of water samples from the valley-fill aquifers are similar to those of samples from the carbonate-rock aquifer, ranging from 0.70957 to 0.71756 . The median SIR values for water from the carbonate-rock and valley-fill aquifers were similar $(0.71149$ and 0.71104 , respectively).

Similarities between SIR's for water from the valley-fill and carbonate-rock aquifers are consistent with the concept of water from the valley-fill aquifer moving downward into the carbonate-rock aquifer. An evaluation of the amount of recharge entering either the valley-fill aquifers or the carbonate-rock aquifer at the valley walls and the possible contribution of water from the gneiss rock is not possible from the data collected, in part as a result of the large variability in the SIR's of water from the gneiss rock resulting from its variable composition. The SIR's in some samples of water from wells in the carbonate-rock aquifer near the valley walls were sufficiently high to indicate possible mixing with water from the leucogneiss. The SIR data together with the CMR data indicate that water from the gneiss rock may move into the carbonate-rock aquifer, but the results are not definitive. 


\section{Interoretation of dissolved-oxygen concentrations in around water}

Because dissolved oxygen (DO) tends to be consumed by bacterial action as ground water moves along a flowpath, older water commonly is less oxygenated than younger water. Tritium-concentration data indicate that much of the water sampled in the study area is fairly young; dissolved-oxygen data tend to support this interpretation, as most of the wells sampled yielded water that contained substantial concentrations of DO. Seventy-one wells were sampled for DO; of these, 52 yielded water with DO concentrations greater than $5 \mathrm{mg} / \mathrm{L}$ and 35 yielded water with DO concentrations greater than $7 \mathrm{mg} / \mathrm{L}$. Only eight wells yielded water with concentrations of DO less than $1 \mathrm{mg} / \mathrm{L}$. About 0.75 miles south of Succasunna, a shallow well in the upper valley-fill aquifer (27-1095) yielded water with very low DO concentrations $(0.01 \mathrm{mg} / \mathrm{L})$; water from an adjacent well (27-1094) tapping the lower valley-fill aquifer also contained fairly low DO concentrations $(1.8 \mathrm{mg} / \mathrm{L})$. The general chemical character of the water from these two wells indicates that water could be moving upward from the underlying carbonate-rock aquifer. This interpretation tends to support the results of the ground-water-flow simulation (discussed later), which simulates upward flow across the bottom of the lower valley-fill aquifer under recent, steady conditions in this area. Relatively reducing conditions may be present in the upper valley-fill aquifer in this area where water is discharging to adjacent wetlands, rather than the oxidizing conditions expected in a recharge area. Water from the two USGS observation wells in the Black River Wildlife Management Area (27-1164, 27-1125) that contained tritium in concentrations less than the reporting limit had moderate DO concentrations (6.2 and $5.8 \mathrm{mg} / \mathrm{L}$, respectively), which indicates that these wells may tap water that is a mixture of young, probably oxygenated water and older, probably less oxygenated water.

\section{Effects of Land Use on Water Quality}

The premise that human activities can affect the quality of ground water has been tested and found to be valid in a number of studies that have examined relations between land use and ground-water quality. Key constituents that are addressed by New Jersey and U.S. Environmental Protection Agency drinkingwater regulations and that have been linked to human activities are nitrate, chloride, and a suite of VOC's that include benzene compounds and chlorinated solvents, such as trichloroethylene. Results of previous studies in New Jersey indicate that VOC's are detected more frequently in ground water underlying urban land than in ground water underlying other land-use areas (Barton and others, 1987). Elevated chloride concentrations in ground water have been traced to the use of road salt (Locat and Gelinas, 1989), but chlorides also can be contributed by effluent from sewage-treatment facilities and septic systems. Elevated nitrate concentrations can be linked to septage and fertilizer use (Eccles and Bradford, 1977; Kreitler and others, 1978; Flipse and others, 1984). In their study of the presence of nitrates in ground water throughout the United States, Madison and Brunett (1984) suggest that nitrate concentrations in excess of $3 \mathrm{mg} / \mathrm{L}$ commonly indicate sources related to human activities. In New Jersey, Louis and Vowinkel (1989) found concentrations of nitrate in excess of the MCL of $10 \mathrm{mg} / \mathrm{L}$ in water underlying agricultural land in the Coastal Plain, clearly showing that the use of fertilizers there can affect water quality.

Because most of the organic compounds referred to as VOC's are not found in nature, the presence, however small, of these compounds in water resources is evidence of the susceptibility of that water resource to contamination. Results of a previous study by the New Jersey Department of Environmental Protection in the Kenvil area showed that nearly 30 private wells in the valley-fill aquifers yielded water containing one or more VOC's in concentrations exceeding drinking-water regulations (R.A. Gallagher, New Jersey Department of Environmental Protection and Energy, written commun., 1989). In the present study, VOC's were detected in water from each of the water-bearing units sampled in the study area. The compounds detected included chloroform, cis-1,3- dichloropropene, 1,1,2-trichloroethane, 1,1-dichloroethylene, trichloroethylene, and tetrachloroethylene. Of the samples from the 12 wells that yielded water containing VOC's (see fig. 25 and table 5), only one sample contained more than one compound, and only two samples contained a concentration that exceeded the MCL. Nonetheless, the results of the New Jersey Department of Environmental Protection and Energy study and the relatively low concentrations of VOC's detected in the 12 samples collected in the present study do indicate that constituents related to human activities and introduced at or near the land surface are capable of adversely affecting ground-water quality. 


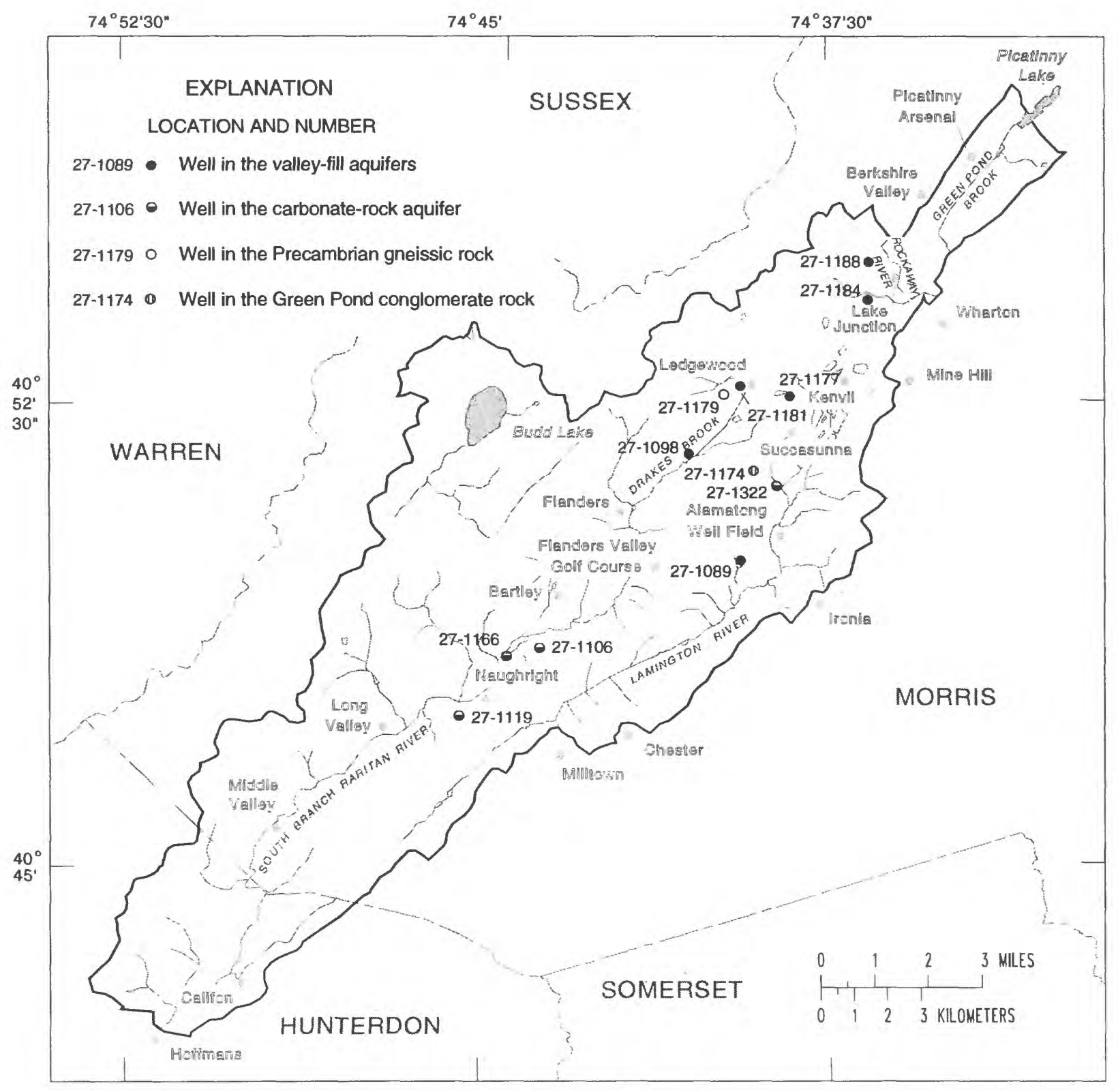

Figure 25. Locations of wells yielding water with volatile organic compounds in concentrations above the minimum reporting limit. 
Table 5. Volatlle organic compounds found In uround-water samples from the study area near Long Valley in concentrations greater than. the minimum reporting limits

[Aquifer codes: 112SFDF, stratified drift; 350GRPD, Green Pond conglomerate; 374LSVL, Leithsville Formation; 400PCMB, Precambrian gneiss; VOC, volatile organic compounds; $\mu \mathrm{g} / \mathrm{L}$, micrograms per liter]

\begin{tabular}{|c|c|c|c|c|c|}
\hline $\begin{array}{l}\text { New Jersey } \\
\text { well number }\end{array}$ & $\begin{array}{c}\text { Well } \\
\text { identifier }\end{array}$ & $\begin{array}{l}\text { Aquifer } \\
\text { code }\end{array}$ & $\begin{array}{l}\text { Date of } \\
\text { sample }\end{array}$ & Compound name & $\begin{array}{c}\text { VOC } \\
\text { concentration } \\
(\mu \mathrm{g} / \mathrm{L})\end{array}$ \\
\hline $27-1089$ & Chudoba 1 & $112 \mathrm{SFDF}$ & $8-10-88$ & bromomethane & $1-4$ \\
\hline $27-1098$ & Bohs 1 & $112 \mathrm{SFDF}$ & $8-11-88$ & bromomethane & $1-4$ \\
\hline $27-1177$ & RWC-PWG-Kentwood Rd. & 112SFDF & $8-22-89$ & tetrachloroethylene & 3.1 \\
\hline $27-1181$ & Beagle Dom & 112 SFDF & $8-23-89$ & trichloroethythlene & .4 \\
\hline $27-1184$ & Herrs Motor Express Com & 112SFDF & 8-23-89 & cis-1,3-dichloropropene & .8 \\
\hline $27-1188$ & L Berksh V Meth Church 1 & 112 SFDF & $8-24-89$ & methylene chloride & 2.0 \\
\hline $27-1174$ & Roka Dom & 350GRPD & $10-31-89$ & chloroform & 2.3 \\
\hline $27-1106$ & W Morris Central HS & 374LSVL & $8-24-88$ & 1,1,2-trichloroethane & $0.5-1$ \\
\hline $27-1119$ & Long Valley Presb Church & 374LSVL & $8-25-88$ & 1,1-dichloroethylene & 3.1 \\
\hline $27-1166$ & Zaikowski Dom & 374LSVL & $11-1-89$ & trichloroethylene & .6 \\
\hline $27-1179$ & Lozauskas Dom & $400 \mathrm{PCMB}$ & $8-21-89$ & chloroform & 3.1 \\
\hline $27-1322$ & RWC 1AT & 374LSVL & 11- 3-89 & trichloroethylene & .3 \\
\hline
\end{tabular}

${ }^{1}$ VOC concentration: analysis for volatile organic compounds done at U.S. Geological Survey, New Jersey District laboratory. Detection limit of gas-chromatograph analysis was $0.2 \mu \mathrm{g} / \mathrm{L}$ at the time of the analysis; however, low-level detections were considered semiquantitative and are given as a range of $0.5-1$ or $1-4 \mu \mathrm{g} / \mathrm{L}$.

${ }^{2}$ Methylene chloride detected at $2 \mu \mathrm{g} / \mathrm{L}$ at the New Jersey District laboratory was not detected in subsequent analysis by the U.S. Geological Survey National Water Quality Laboratory in Colorado. 
As discussed previously, concentrations of nitrate were found to be small in most of the groundwater samples collected during 1988-90. Aquifer materials are unlikely to contribute nitrate to ground water; therefore, nitrate introduced to the aquifers comes from precipitation and from various substances deposited at or near the land surface.

Figure 26 shows the locations of wells yielding water with nitrate concentrations greater than $1 \mathrm{mg} / \mathrm{L}$. In general, water from the gneiss rock contained low concentrations of nitrate. The largest nitrate concentrations were in water from a well and an adjacent spring in the carbonate-rock aquifer; both sites (27-1157 and 27-1158) are located in an agricultural area where manufactured fertilizers and livestock manure are possible sources of nitrate. Water samples from a cluster of wells south of Flanders contained concentrations of nitrate greater than $3 \mathrm{mg} / \mathrm{L}$. These wells, two finished in the lower valley-fill aquifer and two in the carbonate-rock aquifer, are located on what is now commercial, residential, and farm land, but appear to be tapping water that reflects past agricultural practices. Fertilizers used at a local golf course to the east also could contribute nitrates to the ground water. Ground-water flow in this area has a downward component (pl. 1e); nitrate-bearing water from the surface apparently moves down through the lower valley-fill aquifer to the carbonate-rock aquifer.

An elevated nitrate concentration also was found in water from a well (27-1188) in Lower Berkshire Valley. Bacteria levels in the water from this well also had been elevated in the past, but this has been corrected (Abe Burd, Lower Berkshire Valley Presbyterian Church, oral commun., September 14, 1992). Although the source of the nitrate is not readily apparent, the past bacteria problem indicates that it may be related to septic-system effluent. Ammonium concentrations, which typically were less than $1 \mathrm{mg} / \mathrm{L}$ in nearly all samples collected during $1988-90$, also were elevated $(2.3 \mathrm{mg} / \mathrm{L})$, and traces of trichloroethane were detected. A similar suite of contaminants was seen in water from a well tapping the conglomerate rock, in which a nitrate concentration of $8.3 \mathrm{mg} / \mathrm{L}$ was measured and low concentrations of three VOC's were detected. These instances all point to sources of nitrates that are related to human activities, and indicate that shallow ground-water resources are susceptible to contamination from activities at the land surface.

Results of the sampling done during 1988-90 indicate that chloride concentrations exceeded 10 $\mathrm{mg} / \mathrm{L}$ in 28 of 75 samples. Concentrations ranged from 11 to $100 \mathrm{mg} / \mathrm{L}$; the median concentration was 39.5 $\mathrm{mg} / \mathrm{L}$. A substantial number of these wells yielded water containing traces of VOC's or elevated nitrate concentrations. Nevertheless, because 37 of the remaining 47 samples contained chloride concentrations less than $5 \mathrm{mg} / \mathrm{L}$, it appears likely that background concentrations of chloride in ground water in the waterbearing units of the study area generally are less than $5 \mathrm{mg} / \mathrm{L}$.

Figures 27-29 show that elevated chloride concentrations tend to be clustered in each of the major water-bearing units. Chloride concentrations ranging from 12 to $100 \mathrm{mg} / \mathrm{L}$ were found in water from several wells in the areas of Ledgewood, Kenvil, and Lower Berkshire Valley in the northern part of the study area. Elevated nitrate concentrations were found in water from some of the same wells. In the central part of the study area, in the vicinity and south of Long Valley, three wells and a spring located on agricultural land yielded water with elevated concentrations of chloride; water samples from two of these locations also contained nitrate concentrations that are near the MCL for nitrate, and the other two contained nitrates in concentrations greater than $2 \mathrm{mg} / \mathrm{L}$. In the southern part of the study area, several wells in the area of Califon yielded water with chloride concentrations between 10 and $20 \mathrm{mg} / \mathrm{L}$. Despite what appear to be elevated concentrations of chloride, the samples from this latter group of wells did not contain any other constituents in concentrations that pointed clearly to a source related to human activities, unlike the wells in the northern and central parts of the study area. The elevated chloride concentrations found in groundwater samples from the northern and central parts of the study area most likely are derived from human activities. In agricultural areas, elevated chloride concentrations may be linked to the use of potassium chloride as a plant nutrient; in urban and suburban areas, they could be the result of applying road-deicing salt in winter. Septic- system effluent also can be a source of chloride in ground water. 


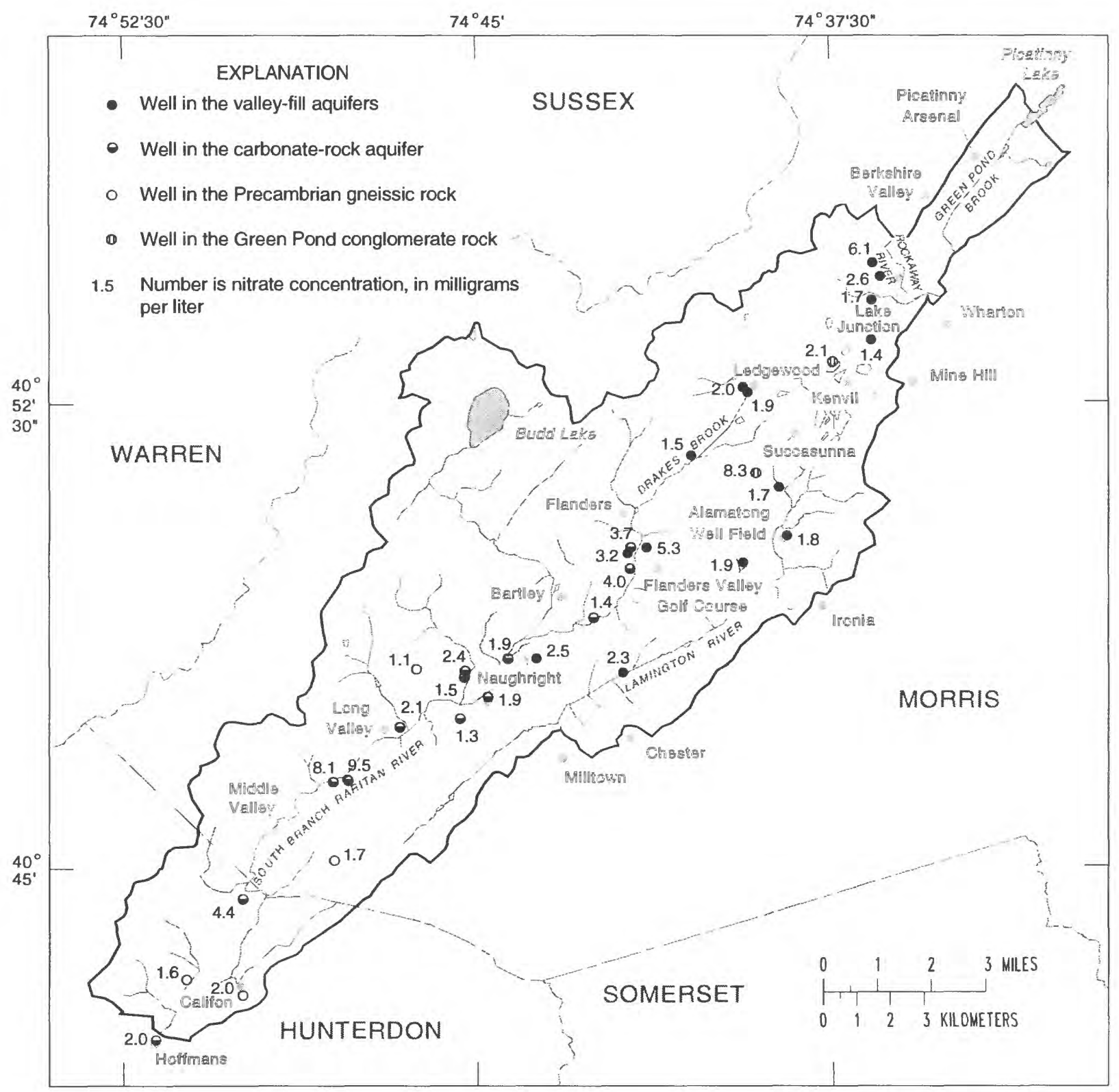

Figure 26. Concentrations of nitrate greater than 1 milligram per liter in ground water in the study area. 


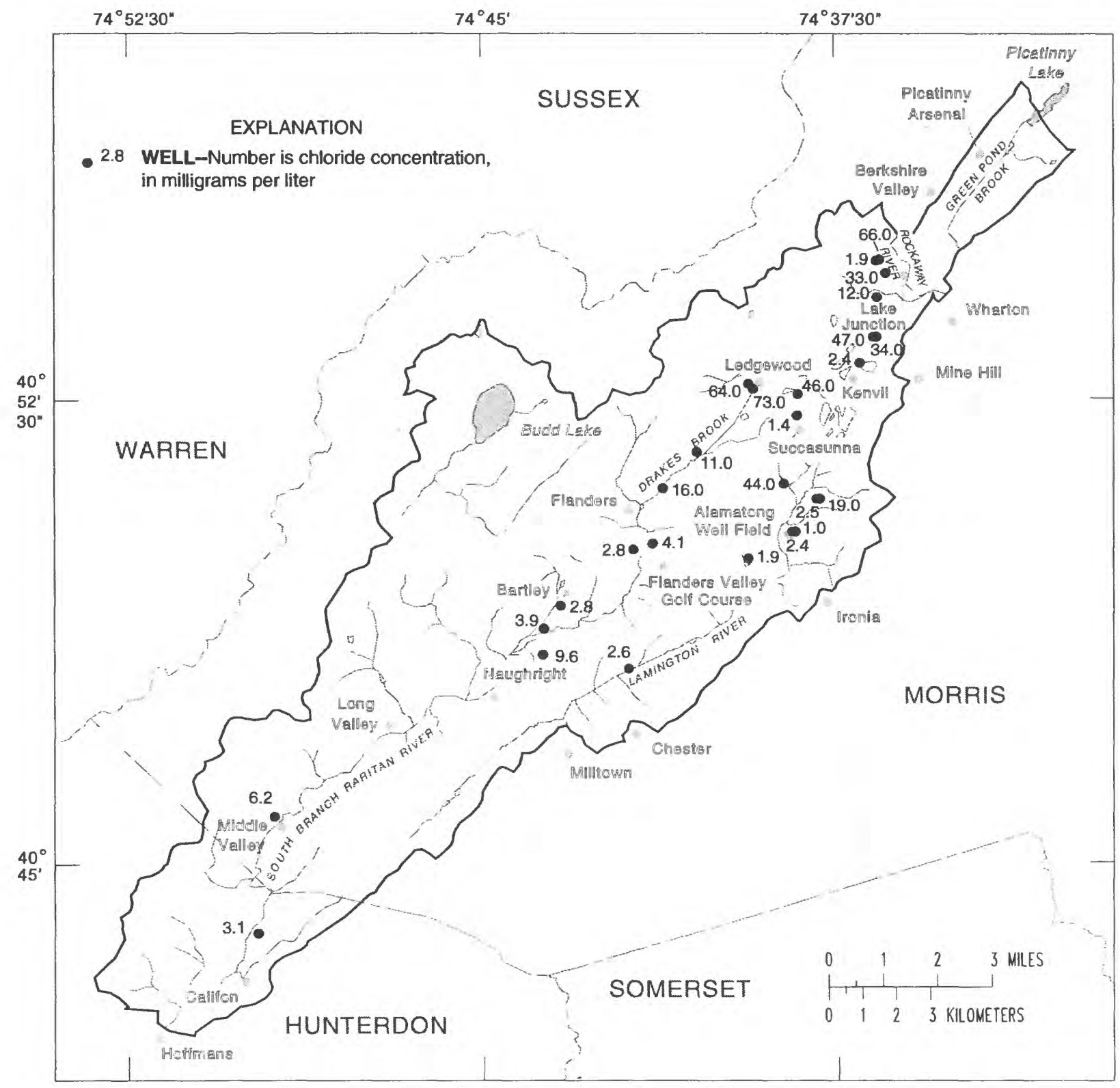

Figure 27. Concentrations of chloride in water from wells in the valley-fill aquifers. 


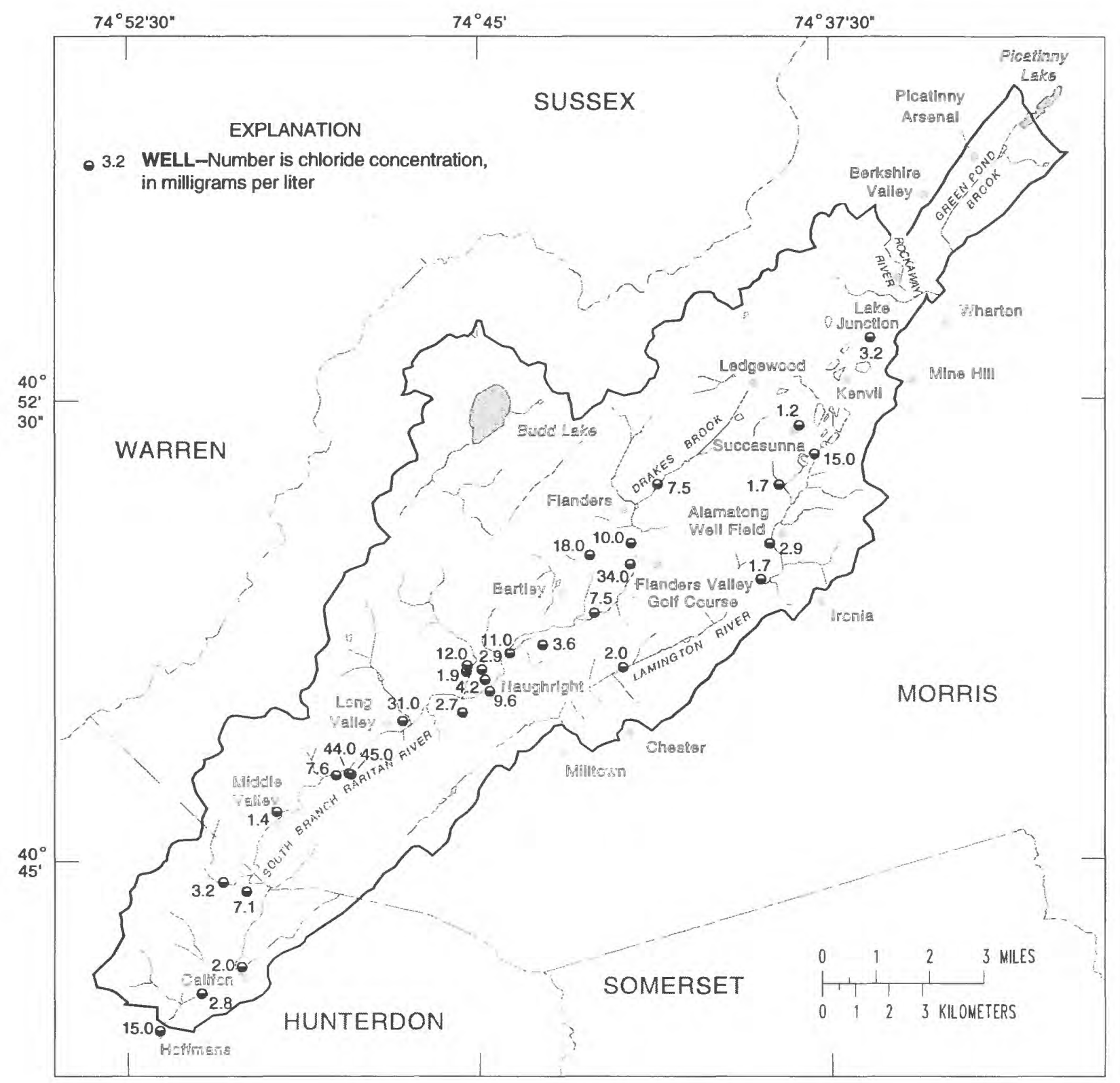

Figure 28. Concentrations of chloride in water from wells in the carbonate-rock aquifer. 


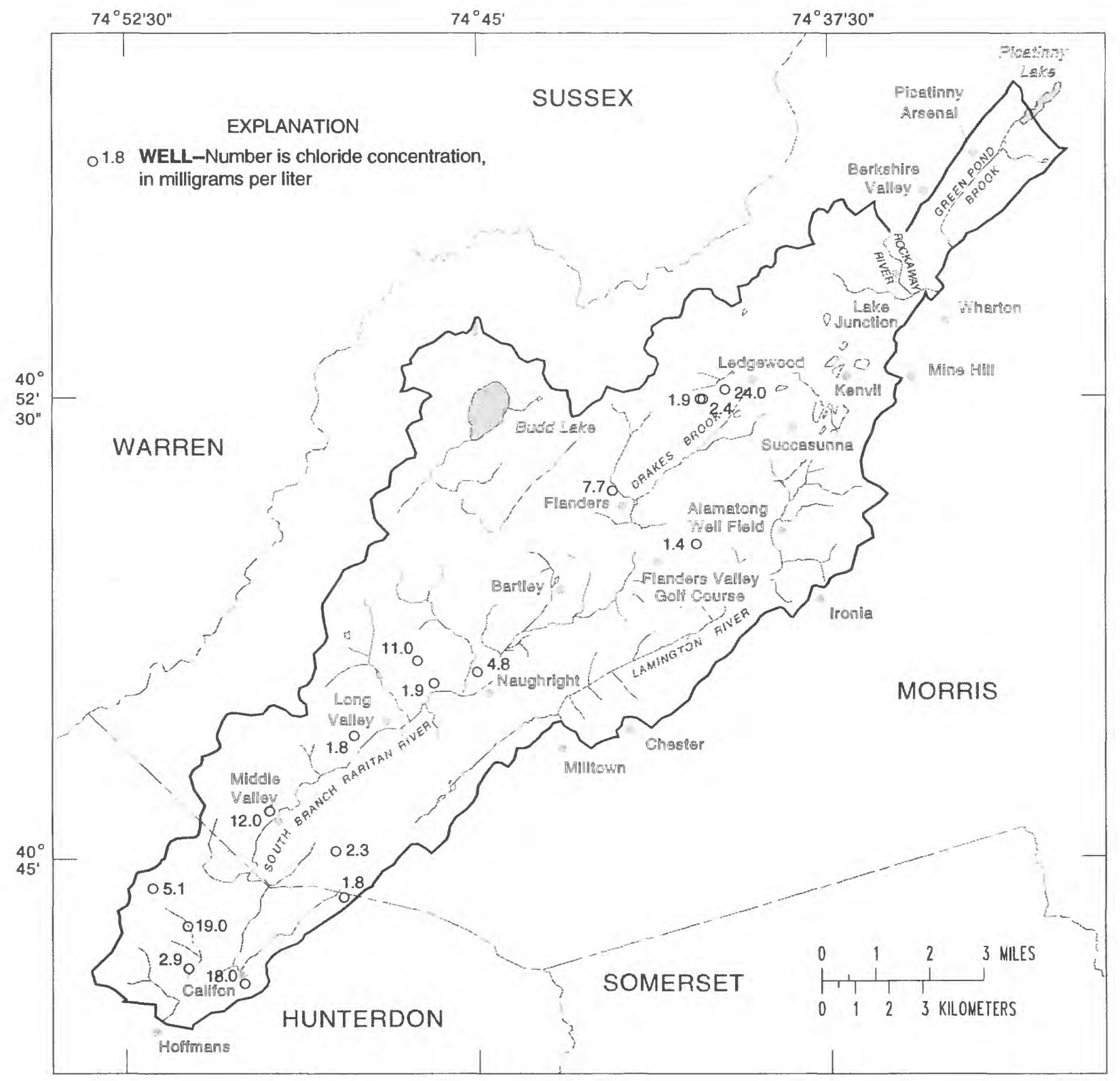

Figure 29. Concentrations of chloride in water from wells in Precambrian gneissic rock. 


\section{GROUND-WATER FLOW}

The following sections describe the techniques and results of an analysis of ground-water flow in the aquifer system. The conceptual flow model on which the analysis is based is presented, and boundary conditions used in numerical simulations are described. The ground-water-flow system under recent conditions is defined in terms of an annual water budget, average water levels, and average gradients. Recent transient water-level responses to seasonal recharge variations and stresses are interpreted, and analyses of transient responses observed during aquifer tests are presented. The sensitivity of model outputs to variations in model input parameters is evaluated, providing an indication of the extent to which those parameters control flow in the system. Predevelopment flow conditions are evaluated and compared with recent conditions to show the effects of recent ground- water withdrawals on water levels and the water budget. The hydrologic effects of anticipated increases in ground-water withdrawals are evaluated, including estimates of water-level changes, base-flow depletion, and changes in the water budget.

\section{Conceptual Model}

In order to analyze the complex physical system of ground-water flow, a simplified conceptual model is required. The following discussion summarizes the conceptual model used in analyzing the ground-water-flow system.

As described earlier, the valley-fill and carbonate-rock aquifer system consists of two unconsolidated aquifers of primarily glacial origin, a carbonate-rock aquifer, and two intervening confining units (pl. 1f). The upper valley-fill aquifer is unconfined throughout its extent, and ground- water flow generally is toward surface-water bodies (fig. 30). The lower valley-fill aquifer is confined in the northern part of the study area and unconfined in the central part, where both the upper confining unit and upper valley-fill aquifer are absent (fig. 31). In areas where the lower valley-fill aquifer is unconfined, ground-water flow generally is toward surface-water bodies; where it is confined, flow is primarily toward pumping centers, major rivers, and areas where it is in direct contact with the carbonate-rock aquifer. The carbonate-rock aquifer generally is confined in the northern part of the study area where it is blanketed by thick valley-fill sediments, and in the southern part where the overburden is thick. The carbonate-rock aquifer is unconfined in the southern part of the study area where the overburden is thin or absent, and in areas where the top of the aquifer is several tens of feet higher than the adjacent valley floor (fig. 32). In the southern part of the study area, ground-water flow in the carbonate-rock aquifer generally is toward surface-water bodies; in the northern part, flow is toward pumping centers and major rivers.

Recharge to the aquifer system is by direct infiltration of precipitation, infiltration of runoff from adjacent upland areas, and leakage from surface-water bodies (fig. 33). Upland areas as a source of recharge to aquifers in valley settings are discussed by Morrissey and others (1987) and Lyford and Cohen (1987). Adjacent buried valleys also contribute flow laterally to the aquifer system (figs. 30 and 31). In areas where confined aquifers are present, some of the recharge flows downward in interstream areas from the overlying unconfined aquifer to the confined aquifers. Ground-water discharge from the system includes flow to surface- water bodies, withdrawals from wells (fig. 33), and lateral flow to adjacent valleys (figs. 30 and 31 ). In the unconfined system, ground water discharges locally to the streams in the valleys. Confined aquifers also discharge to streams through upward leakage to the overlying unconfined aquifer and through lateral flow into areas where the aquifers are unconfined and hydraulically connected to streams. Low-permeability, non-carbonate bedrock underlying the system functions as a barrier to ground- water flow, and recharge from adjacent non-carbonate rock is thought to be negligible.

As described earlier, the fracture system in the laterally bounding non-carbonate rock is shallow. As a result, the upland bedrock flow system is not considered to be a pathway for significant recharge to the aquifer system. In the uplands, much of the incident precipitation percolates downward to a shallow fracture system, flows through the fractures, and discharges locally either to streams that dissect the uplands and hillslopes or as springs on the slopes (fig. 33). Flow continuing downward and discharging 


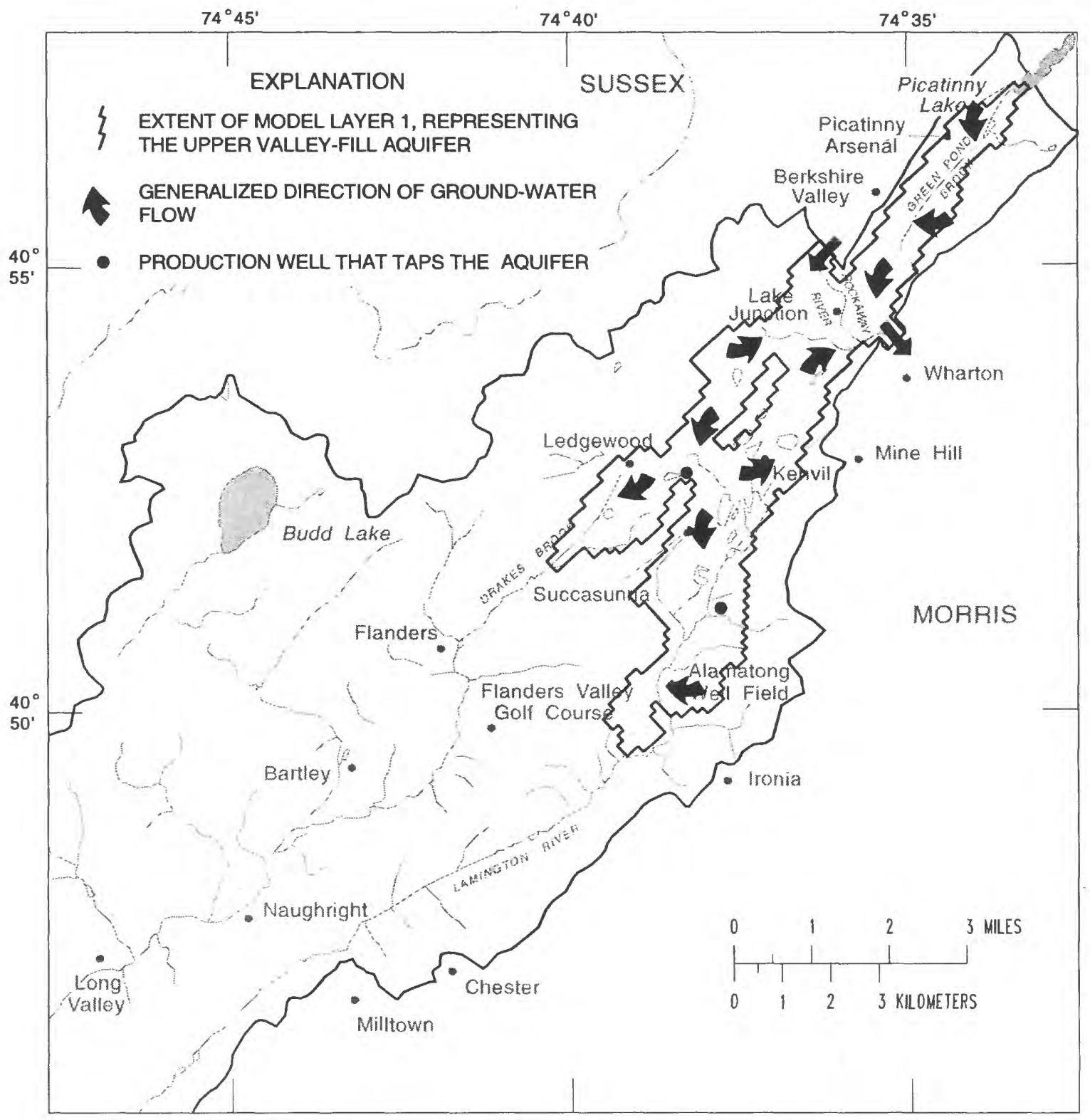

Figure 30. Generalized directions of ground-water flow in the upper valley-fill aquifer. 


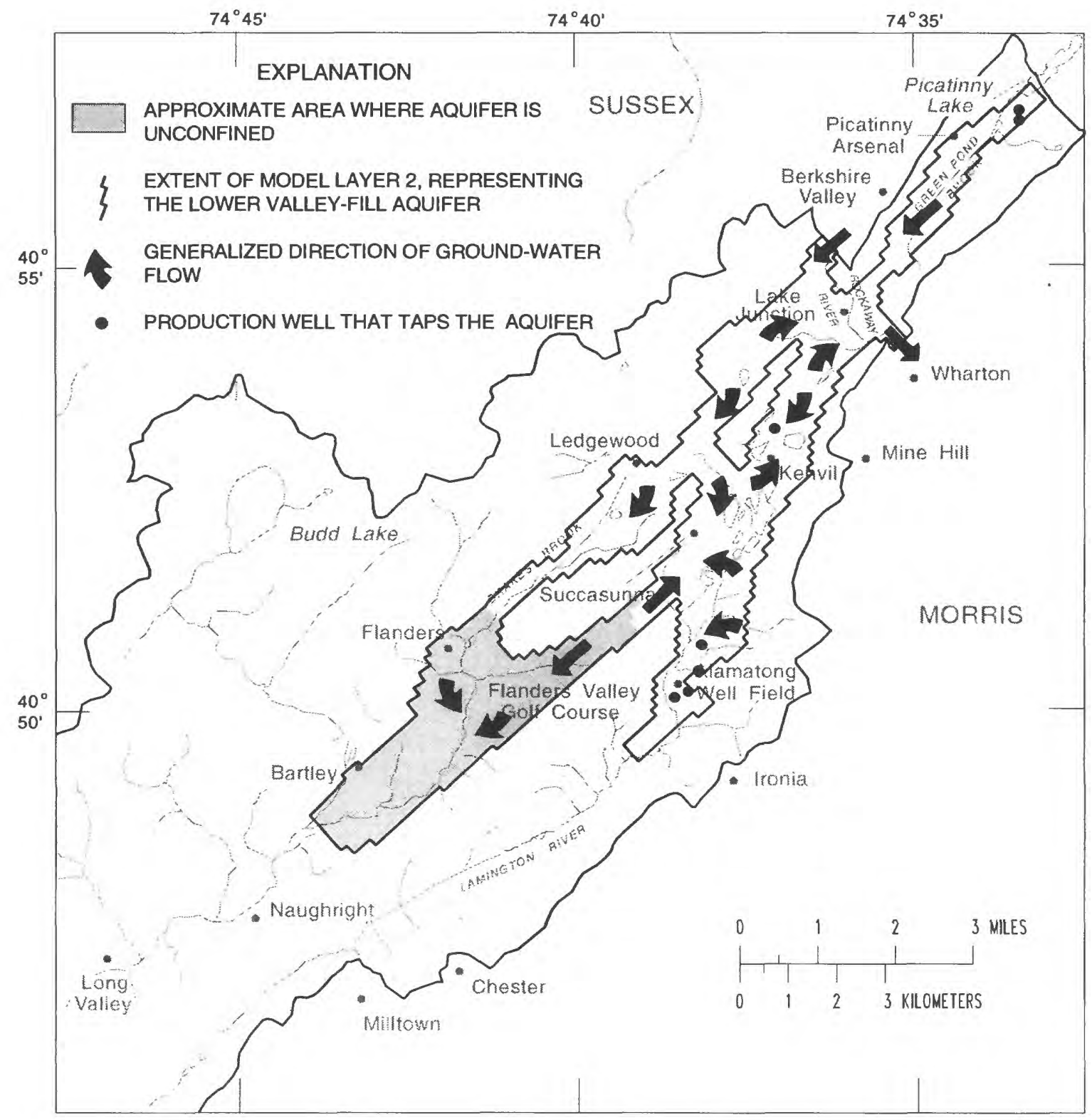

Figure 31. Generalized directions of ground-water-flow in the lower valley-fill aquifer, and areas where the aquifer is unconfined. 


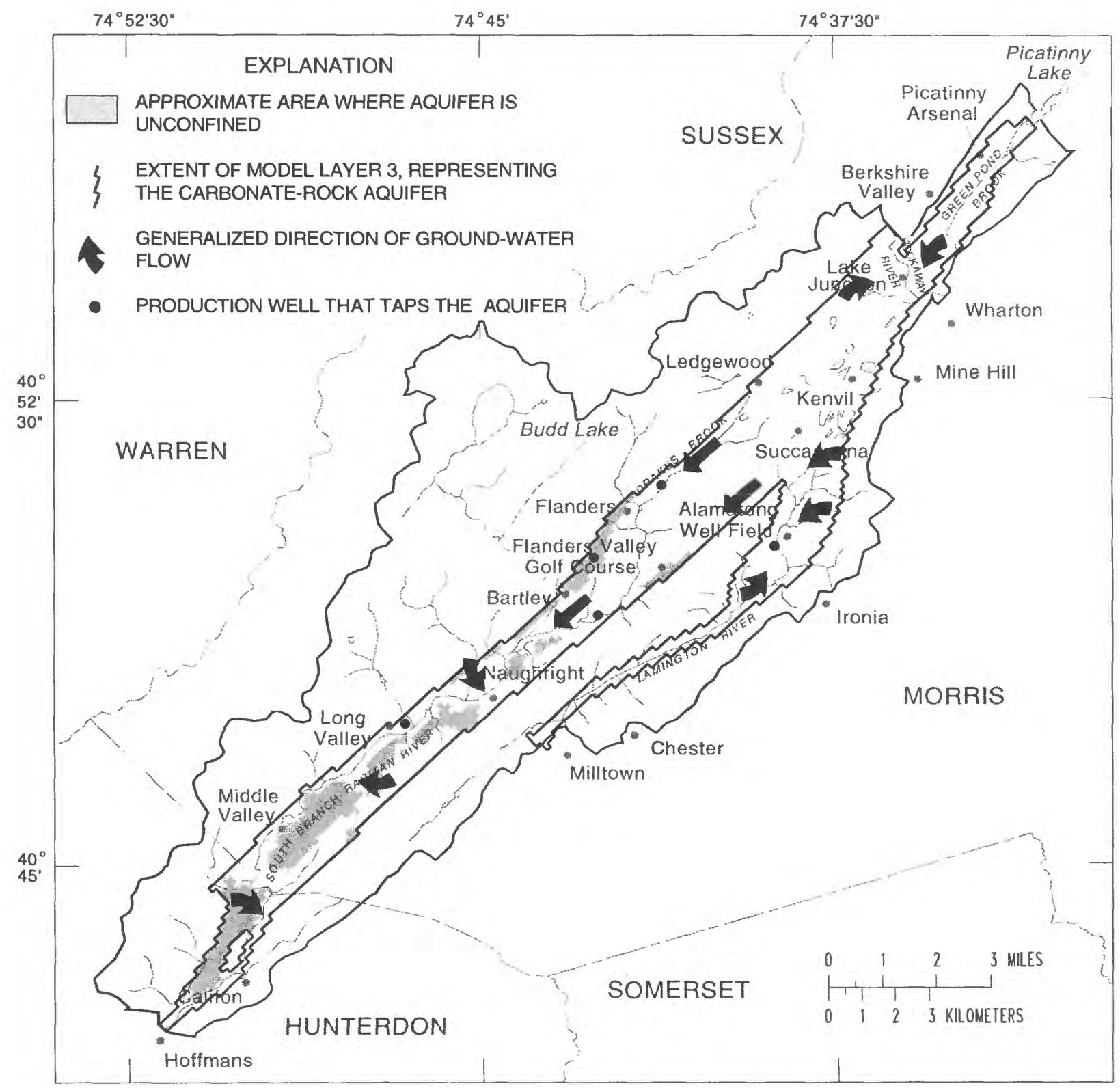

Figure 32. Generalized directions of ground-water-flow in the carbonate-rock aquifer, and areas where the aquifer is unconfined. 


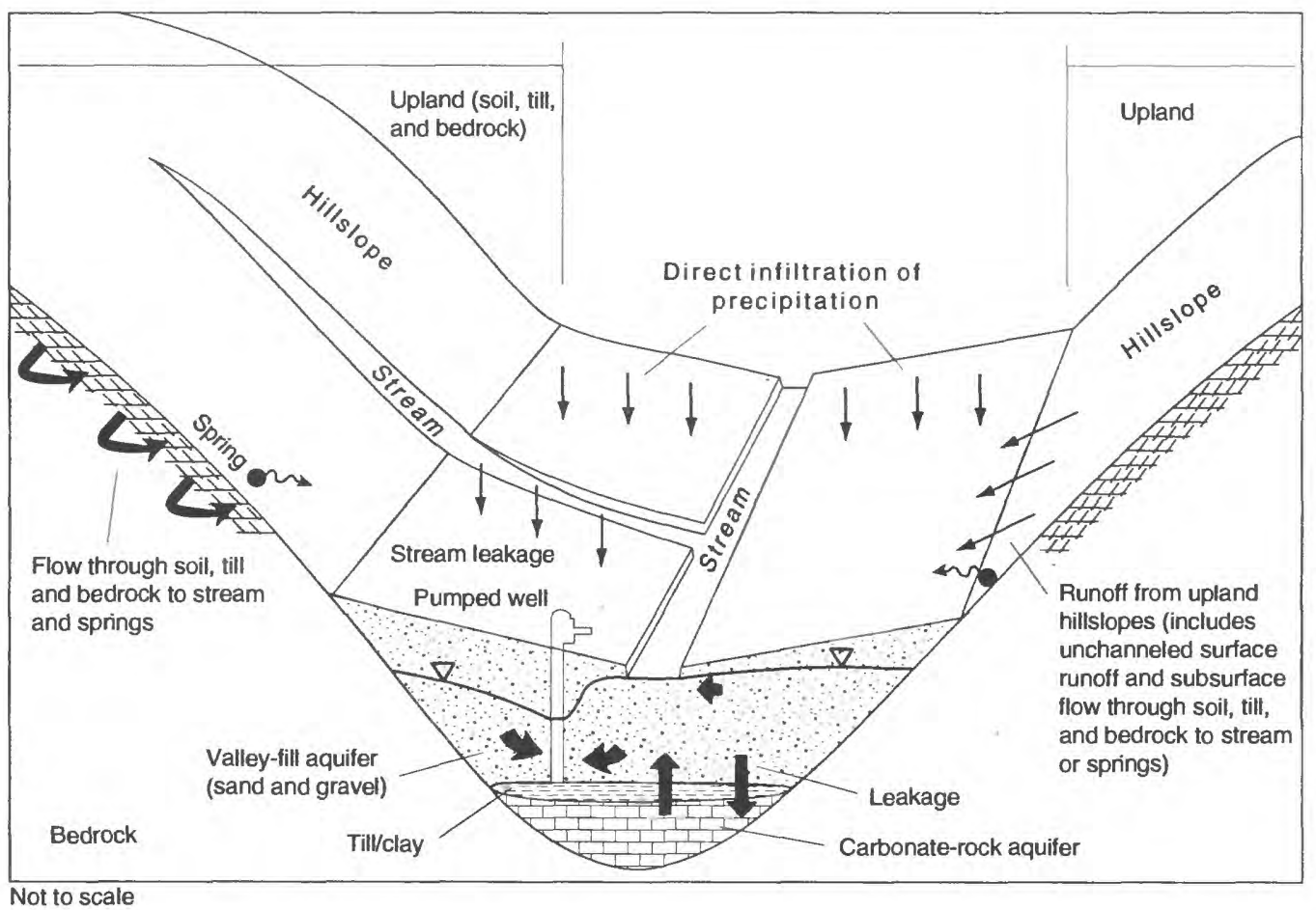

Figure 33. Generalized ground-water flow directions in the New Jersey Highlands study area. (Modified from Lyford and Cohen, 1988, p. 38)

directly to the valley aquifer system is probably insignificant. The concept of a shallow ground-water system in the uplands is supported by two observations. First, springs are present at several locations along the hillslopes, particularly between Flanders and Califon along the hillslope in the western part of the study area (pl. 1a). Second, the analysis of water-quality data did not indicate definitively that a significant amont of water flowing through fractued crystalline rocks was directly entering either a valley-fill or the carbonate-rock aquifer.

Streams that dissect the uplands flow downslope to the valley floor, and eventually enter larger streams. Natural leakage from the streams to the underlying unconfined aquifer commonly occurs near the edge of the valley floor where the water table is typically lower than the stream stage. Base flow from the uplands that does not leak from streams to valley aquifers leaves the study area as surface flow.

Within the aquifer system, ground water flows between the aquifers as leakage through confining units or flows directly between aquifers where confining units are absent. Vertical leakage is the result of vertical gradients caused by natural conditions and by pumping.

\section{Hydrologic Boundaries}

The extent of the aquifer system is defined primarily by natural hydrologic boundaries, with the exception of two areas where ground water flows between the aquifer system and adjacent valley-fill aquifers of the upper Rockaway River valley (figs. 30 and 31). The natural boundaries are (1) the contact between the aquifer system and non-carbonate bedrock, (2) surface-water bodies, and (3) the recharge boundaries discussed earlier. The underlying and laterally bounding non-carbonate bedrock is considered a no-flow boundary. Flow between the aquifer system and surface-water bodies is a function of the gradi- 
ent between the surface water and the ground water, and the hydraulic properties of the bottom sediments. Surface-water bodies were represented as head-dependent flux boundaries, with flow to or from each boundary determined according to the idealization described by McDonald and Harbaugh (1988, p. 6-1 to 6-13). Some surface-water bodies gain flow from the aquifer system, whereas others lose flow to it. Boundary conditions used in the numerical model to represent these hydrologic boundaries and are shown on plate $1 \mathrm{~b}$.

The procedures followed in defining surface-water boundaries are described below. The interaction between surface water and ground water is controlled, in part, by physical characteristics of bottom sediments; however, many of these characteristics are poorly understood. In simulations, this interaction is determined, in part, by a term representing the equivalent streambed conductance of each discretized stream reach. Streambed conductance for each discretized stream reach initially was determined from estimates of stream length and width, streambed thickness, and streambed hydraulic conductivity. The total length of all stream segments represented by each individual model-cell boundary was determined by using a geographic information system. Representative stream widths were determined from field observations and individual widths were assigned to stream cells on the basis of the relative order of the streams represented. First-order streams, second-order streams, third-order streams, and mainstem channels were assigned widths of $5 \mathrm{ft}, 10 \mathrm{ft}, 20 \mathrm{ft}$, and $40 \mathrm{ft}$, respectively. This assignment of widths assured some degree of dependence of streambed conductance on stream order. Effective streambed thickness is unknown and was assigned a value of $1 \mathrm{ft}$. Stream-stage elevation was estimated from 7.5-minute topographic maps and from stream-channel profiles contained in reports that describe flood-hazard areas in the study area (New Jersey Department of Environmental Protection, 1972). The elevation of the bottom of the simulated streambed was assumed to be $2 \mathrm{ft}$ below stream stage. Streambed hydraulic conductivity was unknown and was adjusted during the process of model calibration within a range of 0.02 to $4.0 \mathrm{ft} / \mathrm{d}$, primarily to improve the match between simulated and observed base-flow gains and losses and, to a lesser extent, to improve the match between simulated and observed heads. The resulting range of streambed conductances represented in the calibrated model was $4.0 \times 10^{-4}$ to $5.1 \times 10^{-1} \mathrm{ft}^{2} / \mathrm{s}$.

Lake-stage elevations were determined from results of an altimeter survey. Lakebed conductances were set equal to $0.1 \mathrm{ft}^{2} / \mathrm{s}$, except for the conductance representing the connection between the southern end of Picatinny Lake and the aquifer system. Here the lakebed conductance was set equal to $10.0 \mathrm{ft}^{2} / \mathrm{s}$ in order to simulate the leakage from the lake that is the source of flow to nearby water-supply wells.

Figure 34 shows the distribution of simulated streambed and lakebed conductance values. Low values of conductance in tributary streams generally reflect the smaller widths used in calculating conductances. Other areas where low streambed conductances were used in simulations are the Lamington River south of Ironia and the upper reaches of Drakes Brook. The flow of the Lamington River south of Ironia is sluggish, and field experience has shown that stream-bottom materials are fine-grained. Also, the water level in a shallow observation well near the river (27-1164) is consistently more than 1 foot above land surface, indicating a restricted flow path to the river, probably as a result of the low-conductivity streambottom material. In the upper reaches of Drakes Brook between Ledgewood and Flanders, observed heads in the underlying aquifer are below stream stage, indicating the potential for streamflow loss to the aquifer; simulation results also indicate streamflow loss from this reach. Low values of streambed conductance $\left(0.0005-0.01 \mathrm{ft}^{2} / \mathrm{s}\right)$ were required to limit the simulated streamflow loss there to a reasonable rate.

Higher values of streambed conductance $\left(0.1-0.5 \mathrm{ft}^{2} / \mathrm{d}\right)$ were used along the lower reaches of Drakes Brook and the South Branch Raritan River. Nicholson (1990, p. N-29) interpreted from a water-level hydrograph of an observation well that the carbonate-rock aquifer is in good hydraulic connection with the South Branch Raritan River near Long Valley. This good connection appears likely along the entire mainstem of the river from Bartley to Hoffmans. 


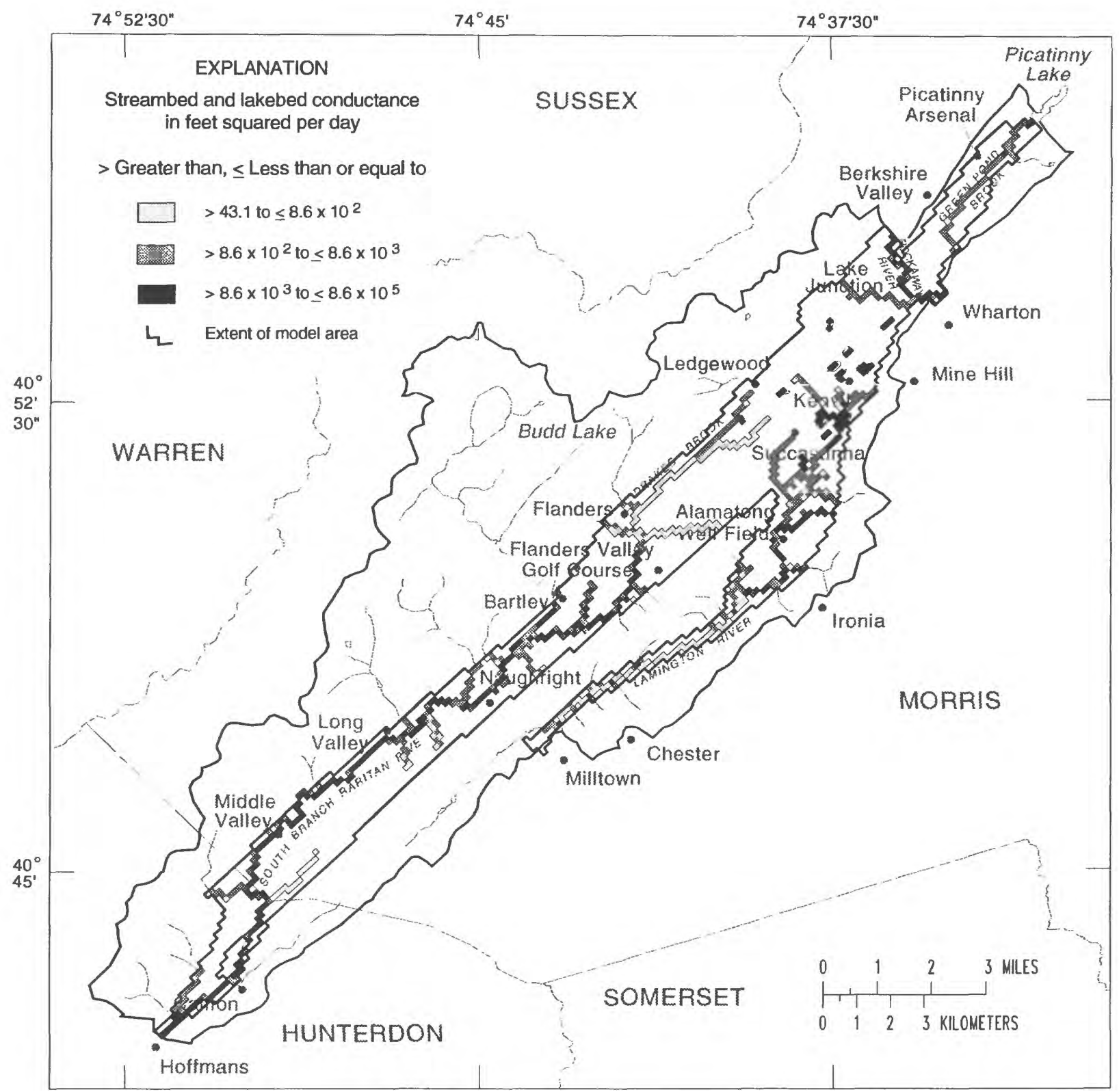

Figure 34. Streambed and lakebed conductance used in the model. 
The upper boundary of the model represents recharge to the aquifer system resulting from the infiltration of direct precipitation and from the infiltration of runoff from adjacent unchanneled upland areas. Recharge was simulated as a specified-flux boundary at cells representing the uppermost aquifer present in a given area. A constant value of flux $\left(1.55 \times 10^{-2} \mathrm{ft}^{3} / \mathrm{s}\right)$ representing infiltration of direct precipitation was applied to each cell receiving recharge. Additional flux $\left(2.0 \times 10^{-2} \mathrm{ft}^{3} / \mathrm{s}\right)$ representing recharge from infiltrating runoff from adjacent uplands was applied to each recharge cell along the valley walls. The determination of the representative recharge rates is described more fully in the subsequent section on the water budget.

The imposition of artificial boundaries was necessary to simulate flow in areas where no natural boundaries are present. Ground water in the valley-fill aquifers of the Rockaway River valley enters the study area as underflow near Berkshire Valley and leaves the study area as underflow near Wharton (figs. 30,31 ). These flows are represented by specified fluxes into or out of the modeled area (pl. 1b). They were initially estimated from measured head gradients and aquifer characteristics by using Darcy's Law, and then adjusted during model calibration. Calibrated fluxes from the adjacent valley near Berkshire Valley were $1.8 \mathrm{ft}^{3} / \mathrm{s}$ into the upper valley-fill aquifer and $0.2 \mathrm{ft}^{3} / \mathrm{s}$ into the lower valley-fill aquifer. Calibrated fluxes to the adjacent valley near Wharton were $0.5 \mathrm{ft}^{3} / \mathrm{s}$ from the upper valley-fill aquifer and $0.3 \mathrm{ft}^{3} / \mathrm{s}$ from the lower valley-fill aquifer.

\section{Recent (1988-89) Steady Conditions}

The techniques and results of an evaluation of recent (1988-89), steady ground-water flow conditions are presented below. A water budget for the aquifer system includes the determination of sources and distribution of recharge to the aquifer system. A comparison of simulated and observed base flow is presented. Recent average ground-water levels and flow directions are described, and simulated and observed water levels and gradients are compared. Together, simulations and interpreted observations of the flow system under recent, steady conditions provide an improved understanding of the recent state of the system and its hydraulic characteristics.

\section{Water Budget}

A water budget is an accounting of water entering and leaving an area, plus changes in stored water, if any, over a particular period of time. Water budgets are useful in understanding the dynamics of the flow system and the limits on water-supply availability. They are also useful in estimating flow-system parameters needed to simulate the system. The systemwide water budget presented below includes estimates of streamflow losses to the aquifer system and the areal distribution of recharge. An evaluation of the distribution of ground-water flow within the system is presented, including a description of the distribution of base flow and a description of the ground-water budget, including flow between aquifers.

\section{Systemwide water budget}

In the following section, two systemwide water budgets for the aquifer system are developed; both are necessary for the estimation of streamflow loss and the distribution of recharge to the aquifer system. The first budget is a land-surface budget, which accounts for precipitation that falls on the land surface, and is used in this report for estimating rates of direct recharge in aquifer outcrop areas. This estimate, in turn, is used to estimate the percentage of total recharge that enters the system as direct recharge. The second type of water budget presented is a ground- water budget, which accounts for all water entering the ground-water system through all sources of recharge and leaving the system as ground-water discharge. The ground-water budget includes additional recharge from upland sources, which is distinguished from direct recharge. The land-surface and ground-water budgets together can be used to resolve conceptual problems posed by the contribution of recharge from adjacent upland areas to the valley aquifer system. Estimates of recharge that resulted from this budget analysis were incorporated in ground-water-flow simulations. 
The land-surface budget was developed to estimate the percentage of total recharge to the valley aquifer system that results from the direct infiltration of precipitation. The equation used to represent the land-surface water budget for valley areas is

$$
\begin{aligned}
P=E T & +D R+R, \\
\text { where } P & =\text { precipitation, } \\
E T & =\text { evapotranspiration, } \\
D R & =\text { direct runoff, and } \\
R & =\text { direct recharge to the valley aquifer system. }
\end{aligned}
$$

Changes in storage were assumed to be negligible for the long periods over which components were averaged. Surface-water withdrawals are negligible.

Precipitation was determined from data collected at the one station within the study area with a long record (Long Valley), and two additional stations with long records that are near, but outside, the study area (Morris Plains and Split Rock Pond) (fig. 35). The average annual precipitation at these three stations for the 30-year period 1951-80 was $50.2 \mathrm{in}$. The long-term average precipitation is considered to be more representative of recent, steady conditions than any short-term average because month-to-month precipitation fluctuates over several inches (fig. 35). Therefore, for the purposes of this analysis, precipitation in the study area $(P)$ is $50 \mathrm{in} / \mathrm{yr}$.

Evapotranspiration (ET) was estimated according to the method of Thornthwaite, as adapted by Mather (1978), by using values of average monthly temperature and precipitation at Long Valley and Morris Plains for the period 1951-80. This method yielded an estimated annual potential evapotranspiration rate of about 25 in., which is considered to be representative of recent, average conditions. These precipitation and evapotranspiration rates are part of a land-surface budget that ultimately is used to determine the percentage of total recharge that results from direct infiltration. The resulting estimated percentage is not sensitive to values of precipitation and evapotranspiration over a range of a few inches.

The third term in the land-surface water-budget equation is direct runoff from the valley land-surface areas. Topography in the $30.7-\mathrm{mi}^{2}$ drainage area of the valleys is flat or rolling and the surficial material is permeable, so that direct runoff of precipitation is lower and recharge through direct infiltration is higher than in upland areas. Hydrograph- separation analysis of available streamflow data for the Lamington River at Succasunna (station 01399190) during 1978-87 was used to estimate direct runoff. This continuous-record station was selected because it is the only station with a continuous streamflow record that drains an area underlain primarily by valley-fill sediments, with few upland tributaries contributing to flow. The drainage area above this station is $7.37 \mathrm{mi}^{2}$, or about 24 percent of the total valley area. The hydrograph-separation program by Sloto (1988) that makes use of the sliding-interval method described by Pettyjohn and Henning (1979) was used. Results of the analysis indicate that average annual direct runoff (DR) for this location and time period was 3 in. If average precipitation (P) is $50 \mathrm{in} / \mathrm{yr}$ and evapotranspiration $\left(E^{T}\right)$ is $25 \mathrm{in} / \mathrm{yr}$ as determined above, solving the budget equation for direct recharge yields a value of $22 \mathrm{in} / \mathrm{yr}$ for the Lamington River Basin above Succasunna. This value includes any recharge to the aquifer system from upland sources; however, recharge to this basin from upland sources is expected to be small. Therefore, for the purposes of this analysis, the value of $22 \mathrm{in} / \mathrm{yr}$ appears to be a best, reasonable estimate of direct recharge to valley aquifers under recent, steady conditions. The resulting land-surface budget for valley areas is

$$
50 \text { in. }(P)=25 \text { in. }(E T)+3 \text { in. }(D R)+22 \text { in. }(R) .
$$

Despite the different time periods used to estimate values for the various components of this budget, the result can be used to determine a reasonable estimate of the proportion of total recharge derived from the direct infiltration of precipitation on valley land-surface areas. The total amount of recharge to the system is determined through a more rigorous analysis of measured flow components, as presented below. 

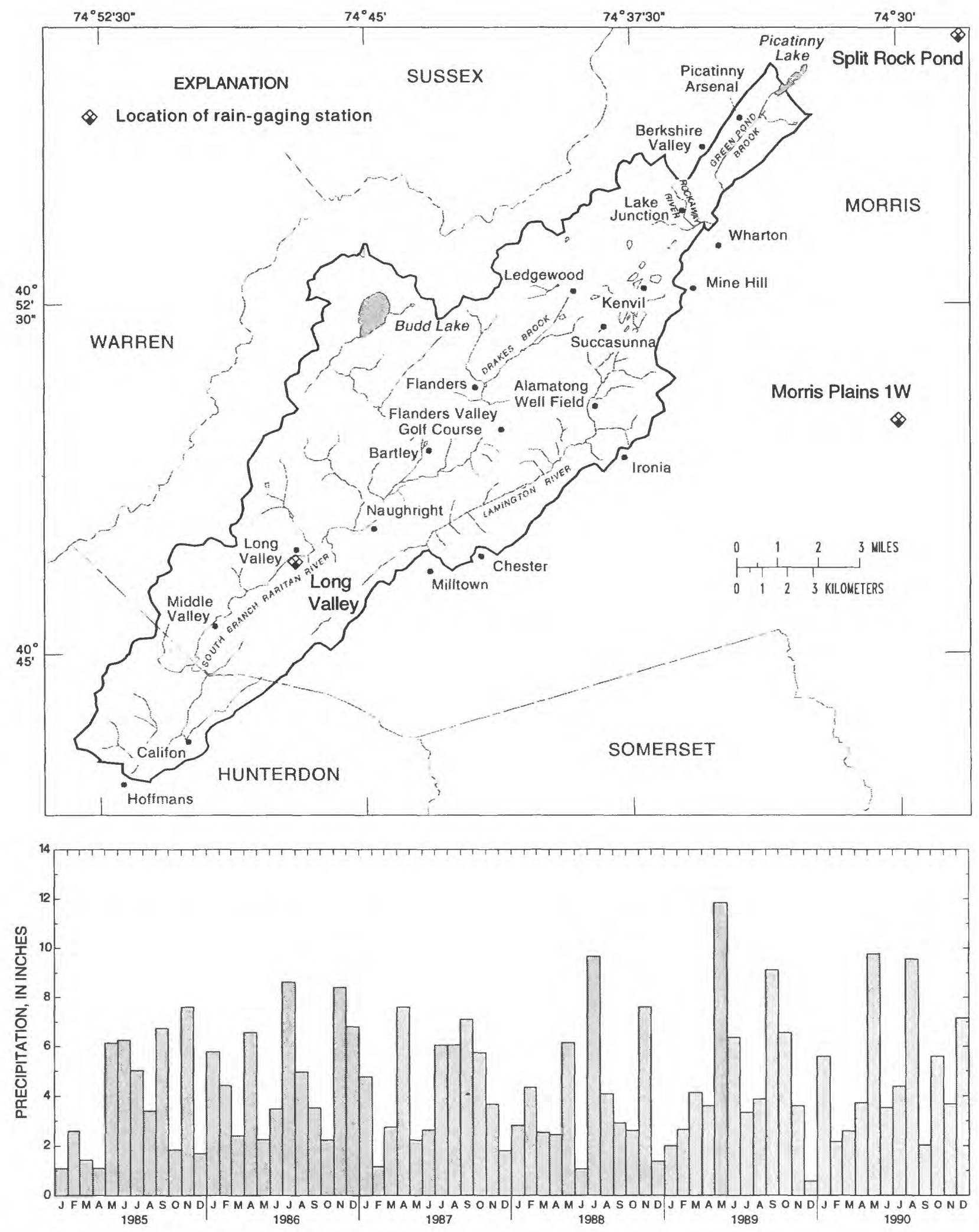

Figure 35. Locations of rain-gaging stations and graph showing monthly precipitation for the period 1985-90. (Monthly values are average values for the three stations) 
The systemwide ground-water budget for the aquifer system is defined by the following equation:

$$
\mathrm{TR}=\mathrm{B}+\mathrm{P}-\mathrm{W}-\mathrm{T},
$$

where TR = total recharge to the aquifer system from all three sources described above,

$\mathrm{B}=$ total measured flow gains (not including direct runoff) for all streams leaving the study area under steady conditions (includes base flow, throughflow, and wastewater return flows)

$P$ = ground-water withdrawals,

$\mathrm{W}=$ return flow as surface discharges of treated wastewater, and

$\mathrm{T}=$ "throughflow" (sum of base flow of upland tributaries entering valley, less streamflow loss to the aquifer system from upland tributaries).

Each of these components is described below. Total recharge to the valley aquifers (TR) consists of direct infiltration of precipitation (as determined above), infiltration of streamflow from upland tributaries, and infiltration of direct runoff from unchanneled upland areas (fig. 33). The land-surface water budget for the valley aquifers defined above provides an estimate of only the first of these three recharge components; the two remaining recharge components must be determined by using the ground-water budget. Measured flow gains (B) totaled $131.9 \mathrm{ft} / \mathrm{s}$, and were determined from recent (1988) average flow gain at locations where four streams exit the study area, less the average flow gain at locations where they enter the study area. Water year 1988 was considered representative of recent, steady flow conditions because average flows during that period were close to long-term averages. The flow gains of the four streams are listed in table 6.

Total monthly pumpage $(\mathrm{P})$ from the aquifer system for 1985-89 is shown in figure 36 and averaged $141 \mathrm{Mgal} / \mathrm{mo}$ for that period. Pumpage reported for April 1989 totaled $140 \mathrm{Mgal}$, or an average of $4.7 \mathrm{Mgal} / \mathrm{d}$, which is representative of recent, average rates. Therefore, April 1989 pumping rates were used in the groundwater budget as $(\mathrm{P})$ and in the simulation of recent, steady-flow conditions. The distribution of pumpage from the three aquifers is shown in figure 37 . Table 7 lists information for the pumped wells.

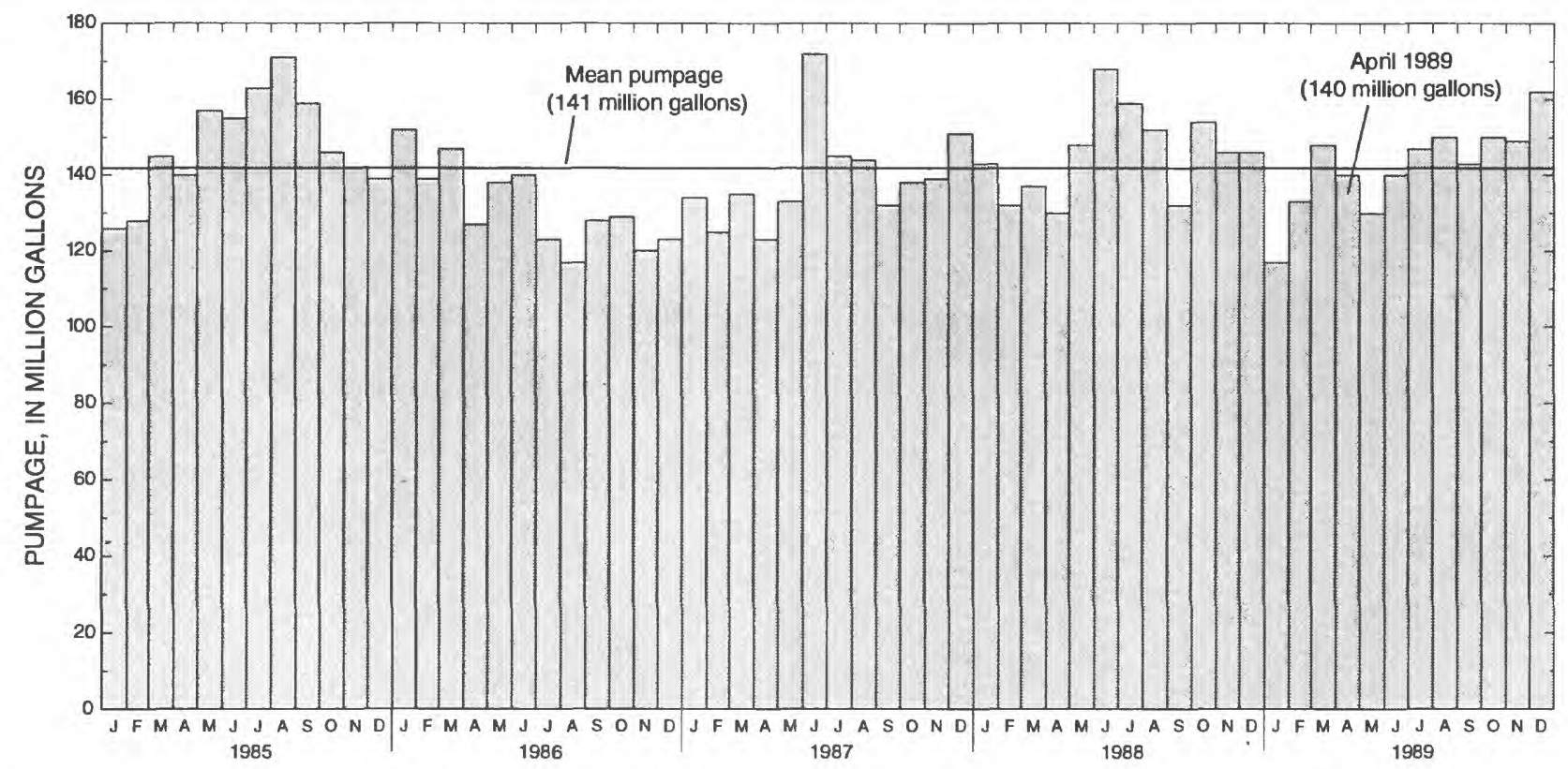

Figure 36. Monthly pumpage from the aquifer system near Long Valley in the New Jersey Highlands, 1985-90. 


\section{Table 6. Estimated recent (1988) average flow gains at locations where streams leave the study area}

[Flow gains include base flow, through flow, and wastewater return flows, but do not include direct runoff; all units in cubic feet per second; see fig. 19 for station locations]

\begin{tabular}{|c|c|c|c|}
\hline Stream & $\begin{array}{l}\text { Estimated } \\
\text { average recent } \\
\text { flow gain }\end{array}$ & Estimated from: & $\begin{array}{l}\text { Method of } \\
\text { flow-gain } \\
\text { estimation }\end{array}$ \\
\hline Lamington River & 35.8 & $\begin{array}{l}\text { Lamington River at Milltown } \\
\text { (station 01399300) }\end{array}$ & $\mathrm{C}$ \\
\hline South Branch Raritan River & 81.5 & $\begin{array}{l}\text { Unit base flow at Califon } \\
(01396350)^{1}\end{array}$ & $\mathrm{C}$ \\
\hline Rockaway River & 7.0 & $\begin{array}{l}\text { Difference in base flow between } \\
\text { station } 0139710 \text { and station } \\
0139740\end{array}$ & C \\
\hline Green Pond Brook & 8.1 & $\begin{array}{l}\text { Difference in base flow between } \\
\text { continuous-record stations } \\
01379780 \text { and } 0139790\end{array}$ & $\mathbf{S}$ \\
\hline Total gain & 132.4 & & \\
\hline
\end{tabular}

${ }^{1}$ Unit base flow at Califon is ( 75.35 cubic feet per second divided by 58.5 square miles) $=1.288$ cubic feet per second per square mile. Drainage area above the study-area boundary at Hoffmans is 63.3 square miles. Estimated average base flow at Hoffmans is $1.288 \times 63.3=81.5$ cubic feet per second.

${ }^{2} \mathrm{C}=$ flow-gain at partial-record stations estimated by using low-flow-correlation techniques; values of base flow for each station are listed in table 8 .

$\mathrm{S}=$ flow-gain at continuous-record stations determined by using base-flow-separation techniques, for water year 1988. 


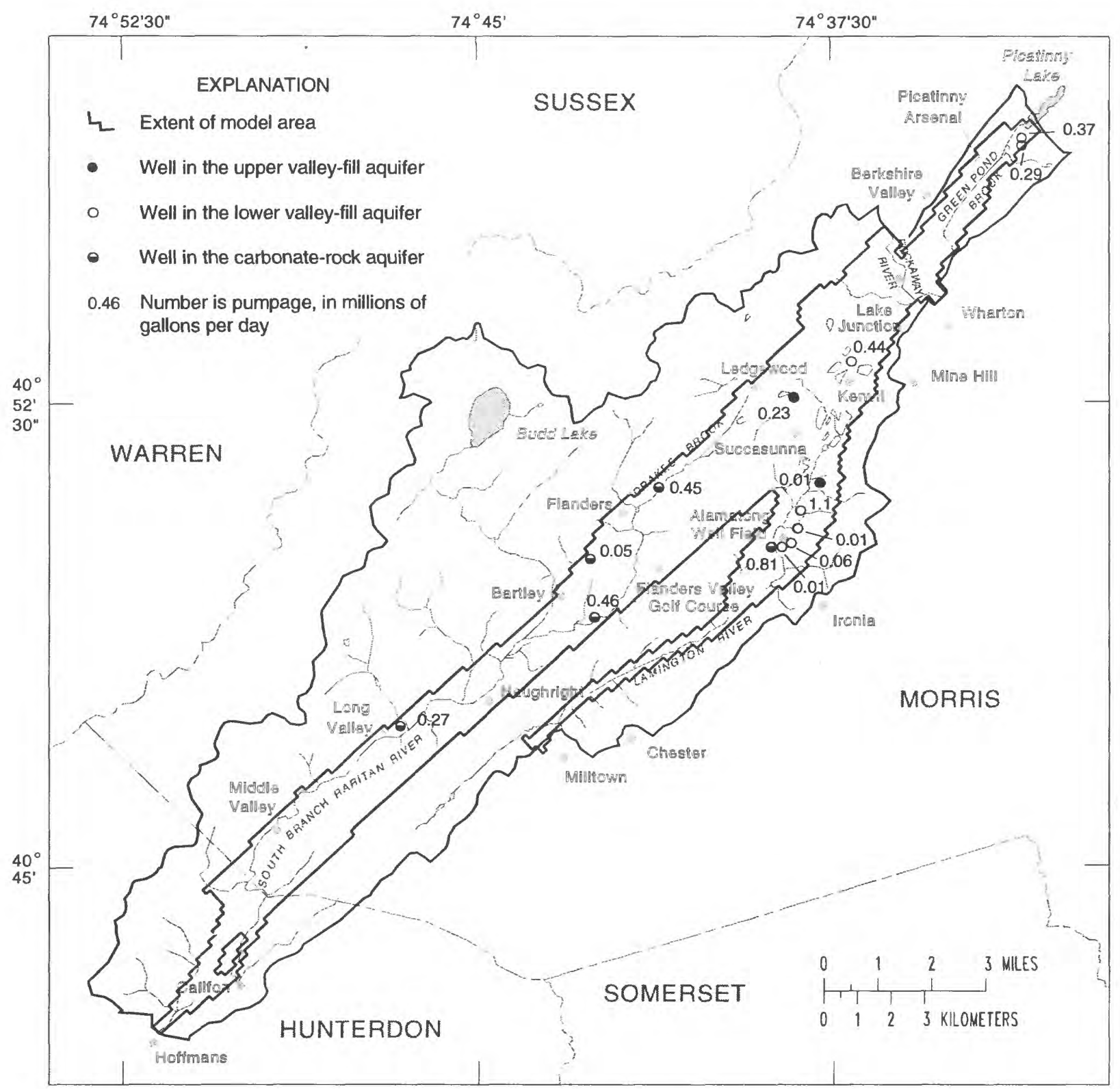

Figure 37. Average pumpage from the aquifer system, April 1989. 


\begin{tabular}{|c|c|c|c|c|c|}
\hline $\begin{array}{c}\text { New } \\
\text { Jersey } \\
\text { well } \\
\text { number } \\
\text { shown } \\
\text { on } \\
\text { plate la }\end{array}$ & Owner ${ }^{1}$ & Local name & $\begin{array}{c}\text { With- } \\
\text { drawal } \\
\text { (million } \\
\text { gallons } \\
\text { per day) }\end{array}$ & $\begin{array}{l}\text { Depth } \\
\text { of well }\end{array}$ & Aquifer tapped \\
\hline $27-0084$ & Picatinny Arsenal & US Army-Picatinny 430A & 0.37 & 82.0 & Lower valley-fill \\
\hline $27-0086$ & Picatinny Arsenal & 410 & .29 & 85.0 & Lower valley-fill \\
\hline $27-9052$ & Hercules, Inc. & Hercules Farm 1 & .44 & 265.0 & Lower valley-fill \\
\hline $27-1177$ & Roxbury Water Company & RWC PW6-Kentwood Rd & .23 & 55.0 & Upper valley-fill \\
\hline $27-1316$ & Westinghouse Elevator Corp & Westinghouse Elev 3 & .01 & 75.0 & Upper valley-fill \\
\hline $27-1173$ & Roxbury Water Company & RWC PW7-Pleasant Vill 1 & .45 & 175.0 & Carbonate-rock \\
\hline $27-1324$ & Morris County M.U.A. & Prod. well \#4 & 1.14 & 180.0 & Lower valley-fill \\
\hline $27-1323$ & Morris County M.U.A. & Prod. well \#3 & .01 & 165.5 & Lower valley-fill \\
\hline $27-1315$ & Morris County M.U.A. & MCMUA PW 2 & .06 & 70.0 & Lower valley-fill \\
\hline $27-1314$ & Morris County M.U.A. & MCMUA PW 1 Alamatong RS & .10 & 80.8 & Lower valley-fill \\
\hline $27-1090$ & Morris County M.U.A. & Morris Co MUA 5 & .81 & 514.0 & Carbonate-rock \\
\hline 27-1092 & Mount Olive Township & Mt Olive Twp Flanders 2 & .05 & 198.0 & Carbonate-rock \\
\hline $27-1093$ & Mount Olive Township & Mt Olive Twp Flanders 3 & .46 & 260.0 & Carbonate-rock \\
\hline \multirow[t]{2}{*}{$27-1160$} & Welsh Farms Inc. & Welsh Farms 1 & .27 & 223.0 & Carbonate-rock \\
\hline & & Total & 4.70 & & \\
\hline
\end{tabular}

1 All Morris County Municipal Utilites Authority wells listed here are located at the Alamatong well field. 
Representative estimates of recent, average wastewater return flows $(W)$ were determined from communications with sewage-treatment-plant operators, managers of commercial and industrial operations, and personnel of the New Jersey Department of Environmental Protection. Recent, average flows were estimated at $2.9 \mathrm{Mgal} / \mathrm{d}$, or $4.5 \mathrm{ft}^{3} / \mathrm{s}$.

Upland crystalline rocks discharge ground water through the shallow fracture system (fig. 33) to upland streams, which then flow into the valleys. Some of this flow leaks from these tributaries to the valley aquifer system; the remainder is throughflow, defined as the amount of upland base flow that does not enter the valley aquifer system, but which passes through the area underlain by the valley aquifer system.

In order to estimate throughflow $(\mathrm{T})$, the total rate of upland base flow that emerges into valleys first needs to be estimated. Base flow in upland areas was estimated for six partial-record stations draining upland areas underlain primarily by crystalline rocks. To estimate base flows, historical low flows at each of these stations were correlated with concurrent low flows at nearby streamflow-gaging stations where surface- water discharge has been measured continuously and recent base flows are known. This correlation technique is described in a subsequent section. The estimates of base flow at each station were used along with the respective drainage areas to estimate an area-weighted average base flow per unit area of uplands. This value, $1.12\left(\mathrm{ft}^{3} / \mathrm{s}\right) \mathrm{mi}^{2}$, is equivalent to $15.2 \mathrm{in}$. annually, which was considered a reasonable estimate of upland base flow. For the entire $63.5-\mathrm{mi}^{2}$ upland area, this is equivalent to a total upland baseflow rate of $71.1 \mathrm{ft}^{3} / \mathrm{s}$.

A check on this estimate of upland base flow per unit area was made by means of a hydrographseparation analysis of the continuous streamflow record of a nearby stream draining an area underlain by crystalline rocks in the uplands where ground-water pumpage is insignificant. Streamflow records for a continuous gaging station on Upper Cold Brook (station 01399510, fig. 19) were analyzed with the hydrograph-separation computer program by Sloto (1988) to estimate base-flow and direct-runoff components of streamflow. The sliding-interval method as described by Pettyjohn and Henning (1979) was used. The average base flow for the period 1978-87 was $16.7 \mathrm{in}$., which compares favorably with the $15.2 \mathrm{in}$. estimated previously. Not all of this upland base flow becomes throughflow, however; some is lost to the valley aquifer system. Because the water table of the valley aquifers is lower than the stream elevation in many areas near the hillslopes, the potential exists for streamflow loss from these upland tributaries.

Few data were available to measure losses from upland tributaries to valley aquifers directly; therefore, the total loss of tributary flow was estimated by calculating leakage with reasonable values of streambed characteristics and vertical head gradient.

The equation used is

$$
Q=\frac{K L W}{M} \times \Delta H
$$

where $\mathrm{K}$ is streambed hydraulic conductivity, assumed to be $3 \mathrm{ft} / \mathrm{d} ; \mathrm{L}$ is stream length over which leakage occurs, estimated to total $17,000 \mathrm{ft}$; $\mathrm{W}$ is the average width of the tributary, estimated to be $10 \mathrm{ft}$; and $\mathrm{M}$ is the streambed thickness, assumed to be $1 \mathrm{ft}$. It was assumed that most tributary leakage occurs under perched stream conditions where the altitude of the bottom of the streambed is higher than that of the underlying water table. Under this assumption, the vertical hydraulic gradient $(\Delta H)$ equals unity. The equation thus yields an estimate of

$$
\frac{\left(\frac{3.0 f t}{d}\right) \times(17,000 f t) \times(10 f t) \times 1}{(1 f t)}=5.1 \times \frac{10^{5} f t^{3}}{d},
$$


or $5.9 \mathrm{ft}^{3} / \mathrm{s}$, which is 8 percent of the estimated average upland base flow $\left(71.1 \mathrm{ft}^{3} / \mathrm{s}\right)$ entering the valleys. A few streamflow measurements at a site upstream and a site downstream from the contact between the uplands and the aquifer system indicate that a loss of this magnitude is reasonable. Streamflow measurements at stations 01396120 and 01396123 (fig. 19) were used to estimate average base flow at the sites by using the low-flow correlation technique described above. Average base flow at station 01396120 , located just upstream from the valley wall, is about $15.1 \mathrm{ft}^{3} / \mathrm{s}$. Average base flow at station 01396120 , located near the center of the valley, is about $14.7 \mathrm{ft}^{3} / \mathrm{s}$. Although no concurrent measurements were available, the estimated average base-flow values indicate a streamflow loss of about $0.4 \mathrm{ft}^{3} / \mathrm{s}$, or 3 percent.

If total upland base flow is $71.1 \mathrm{ft}^{3} / \mathrm{s}$ and tributary leakage to the aquifer system is $5.9 \mathrm{ft}^{3} / \mathrm{s}$, throughflow (T) can be estimated to be the difference, or $65.2 \mathrm{ft}^{3} / \mathrm{s}$.

From the estimates of total flow gains for the study area $\left(132.4 \mathrm{ft}^{3} / \mathrm{s}\right)$, total ground-water withdrawals from all three aquifers $\left(7.2 \mathrm{ft}^{3} / \mathrm{s}\right.$, or $4.7 \mathrm{Mgal} / \mathrm{d}$, and return flows of treated wastewater $\left(4.5 \mathrm{ft}^{3} / \mathrm{s}\right)$, total recharge (TR) to the aquifer system can be calculated as follows:

$$
T R=132.4 \mathrm{ft}^{3} / \mathrm{s}+7.2 \mathrm{ft}^{3} / \mathrm{s}-4.5 \mathrm{ft}^{3} / \mathrm{s}-65.2 \mathrm{ft}^{3} / \mathrm{s}=69.9 \mathrm{ft}^{3} / \mathrm{s} \text {, or about } 70 \mathrm{ft}^{3} / \mathrm{s} \text {. }
$$

Total recharge to the valley aquifers $\left(70 \mathrm{ft}^{3} / \mathrm{s}\right)$ is equal to the sum of direct recharge to valley aquifers $\left(22 \mathrm{in} / \mathrm{yr}\right.$, or $\left.50 \mathrm{ft}^{3} / \mathrm{s}\right)$, leakage from upland streams $\left(6 \mathrm{ft}^{3} / \mathrm{s}\right)$, and infiltration of runoff from unchanneled upland areas. Calculations of the first two of these three components allows calculation of the third component as the difference. Infiltrating runoff from adjacent, unchanneled upland areas is thus

$$
70 \mathrm{ft}^{3} / \mathrm{s} \text { (total recharge) }-50 \mathrm{ft}^{3} / \mathrm{s} \text { (direct recharge) }-6 \mathrm{ft}^{3} / \mathrm{s} \text { (river leakage) }=14 \mathrm{ft}^{3} / \mathrm{s} \text {. }
$$

These rates were incorporated in simulations. The $50 \mathrm{ft}^{3} / \mathrm{s}$ of direct recharge was distributed uniformly to the 3,189 uppermost active cells. The $14 \mathrm{ft}^{3} / \mathrm{s}$ of additional recharge from unchanneled upland areas was distributed uniformly among the 636 uppermost active cells adjacent to valley walls. River leakage was simulated as a head-dependent flux boundary in the model. Through the process of model calibration, parameters were adjusted so that the simulated river leakage was about $6 \mathrm{ft}^{3} / \mathrm{s}$.

\section{Distribution of flow within the system}

The following section describes the distribution of flow within the aquifer system. The simulated ground-water discharge to streams from the aquifer system is compared to ground-water discharge to streams measured at eight streamflow-gaging stations. Simulated base flows agreed closely with average base flows at stations where concern about effects of ground- water-supply development on streamflow is greatest. A simulated ground- water budget is presented that includes rates of flow between aquifers, and rates of recharge and discharge to and from each of the three aquifers.

Table 8 lists average base flow at 21 partial-record stations in the study area, estimated from lowflow correlations with nearby continuous- record stations. The correlation equations shown in this table establish the mathematical relation between flow at the partial-record stations and continuous-record stations and are used to calculate average base flow, under recent conditions, at the partial-record stations. Regression equations for flow were determined by using the Maintenance of Variance Extension, Type 1 method (Hirsch, 1982), with at least three and, in most cases, eight concurrent measurement pairs. High correlations generally are observed between low flows at partial-record stations and concurrent low flows at the continuous-record stations. Average recent (1988) base flows were first determined for the continuous-record stations through a hydrograph-separation computer program (Sloto, 1988). The value of average base flow $\left(Q_{\mathrm{I}}\right)$ is then substituted into the corresponding regression equation to calculate average base flow at the partial-record stations under recent conditions $\left(Q_{P}\right)$. Low flows at two continuous-record stations, Lamington River near Pottersville (01399500) and South Branch Raritan River near High Bridge (01396500), were correlated with those at partial-record stations within these two drainage areas and the two resulting estimates of $Q_{P}$ were averaged. Low flows at the continuous-record station on the Rockaway 
Table 8. Average base flow and results of low-flow-correlation analysis for 21 partial-record measurement sites in the study area

$\left[Q P_{R}\right.$, predicted discharge; $\mathrm{QI}$, continuous-record-station discharge; --, not applicable; $\mathrm{mi}^{2}$, square miles; $\mathrm{ft}^{3} / \mathrm{s}$, cubic feet per second]

\begin{tabular}{|c|c|c|c|c|c|c|c|c|}
\hline $\begin{array}{l}\text { Partial- } \\
\text { record } \\
\text { station } \\
\text { number }\end{array}$ & $\begin{array}{l}\text { Partial-record- } \\
\text { station name }\end{array}$ & $\begin{array}{l}\text { Drainage } \\
\text { area } \\
\left(\mathrm{mi}^{2}\right)\end{array}$ & $\begin{array}{l}\text { Continuous- } \\
\text { record- } \\
\text { station } \\
\text { number }\end{array}$ & $\begin{array}{l}\text { Correlation } \\
\text { coefficient }\end{array}$ & $\begin{array}{l}\text { Correlatic } \\
\text { equation }\end{array}$ & & $\begin{array}{c}\text { Estimated } \\
\text { base flow } \\
\mathrm{QP}_{\mathrm{R}} \\
\left(\mathrm{f}^{3} / \mathrm{s}\right)\end{array}$ & $\begin{array}{c}\text { Average of } \\
\text { estimated } \\
\text { base flows } \\
\quad\left(\mathrm{ft}^{3} / \mathrm{s}\right)\end{array}$ \\
\hline 01379710 & $\begin{array}{l}\text { Rockaway River near } \\
\text { Wharton, N.J. }\end{array}$ & 27.4 & 01379700 & 0.9749 & $\mathrm{QP}_{\mathrm{R}}=\mathbf{0 . 0 8 3 8 9 6}$ & $\mathrm{QI}^{(1.063)}$ & 40.2 & 40.2 \\
\hline 01379740 & $\begin{array}{l}\text { Rockaway River at } \\
\text { West Central Ave at } \\
\text { Dover, N.J. }\end{array}$ & 30.3 & 01379700 & .9668 & $\mathrm{QP}_{\mathrm{R}}=1.44885$ & $\mathrm{QI}^{(0.957)}$ & 47.2 & 47.2 \\
\hline 01396070 & $\begin{array}{l}\text { S. Br. Raritan R. Trib. } 6 \\
\text { at Budd Lake, N.J. }\end{array}$ & 0.7 & $\begin{array}{l}01396500 \\
01399500\end{array}$ & $\begin{array}{l}.9738 \\
.9343\end{array}$ & $\begin{array}{l}\mathrm{QP}_{\mathrm{R}}=0.0008523 \\
\mathrm{QP}_{\mathrm{R}}=0.00436\end{array}$ & $\begin{array}{l}Q I^{(1.562)} \\
Q I^{(1.4949)}\end{array}$ & $\begin{array}{r}.9 \\
1.2\end{array}$ & $-\overline{1.05}$ \\
\hline 01396090 & $\begin{array}{l}\text { S. Br. Raritan R. at } \\
\text { outlet of Budd Lake, } \\
\text { Budd Lake, N.J. }\end{array}$ & 5.03 & $\begin{array}{l}01396500 \\
01399500\end{array}$ & $\begin{array}{l}.9007 \\
.9126\end{array}$ & $\begin{array}{l}\mathrm{QP}_{\mathrm{R}}=0.0000344 \\
\mathrm{QP}_{\mathrm{R}}=0.02122\end{array}$ & $\begin{array}{l}\mathrm{QI}^{(2.6483)} \\
\mathrm{QI}^{(1.514)}\end{array}$ & $\begin{array}{l}5.0 \\
6.1\end{array}$ & $\overline{5.55}$ \\
\hline 01396120 & $\begin{array}{l}\text { S. Br. Raritan R. at } \\
\text { Bartley, N.J. }\end{array}$ & 12.5 & $\begin{array}{l}01396500 \\
01399500\end{array}$ & $\begin{array}{l}.9819 \\
.9641\end{array}$ & $\begin{array}{l}\mathrm{QP}_{\mathrm{R}}=0.05242 \\
\mathrm{QP}_{\mathrm{R}}=0.4587\end{array}$ & $\begin{array}{l}Q I^{(1.2535)} \\
Q I^{(0.9481)}\end{array}$ & $\begin{array}{l}14.5 \\
15.9\end{array}$ & $\overline{15.2}$ \\
\hline 01396130 & $\begin{array}{l}\text { Drakes Brook at Ledge- } \\
\text { wood, N.J. }\end{array}$ & 3.27 & $\begin{array}{l}01396500 \\
01399500\end{array}$ & $\begin{array}{l}.9398 \\
.9688\end{array}$ & $\begin{array}{l}\mathrm{QP}_{\mathrm{R}}=0.0417669 \\
\mathrm{QP}_{\mathrm{R}}=0.09213\end{array}$ & $\begin{array}{l}Q I^{(1.0882)} \\
Q I^{(1.0809)}\end{array}$ & $\begin{array}{l}5.5 \\
5.2\end{array}$ & 5.35 \\
\hline 01396220 & $\begin{array}{l}\text { Stoney Brook at Naugh- } \\
\text { right, N.J. }\end{array}$ & 3.34 & $\begin{array}{l}01396500 \\
01399500\end{array}$ & $\begin{array}{r}0.9687 \\
.9635\end{array}$ & $\begin{array}{l}\mathrm{QP}_{\mathrm{R}}=0.005 \\
\mathrm{QP}_{\mathrm{R}}=0.04495\end{array}$ & $\begin{array}{l}Q I^{(1.4481)} \\
Q I^{(1.1676)}\end{array}$ & $\begin{array}{l}3.3 \\
3.5\end{array}$ & -- \\
\hline 01396280 & $\begin{array}{l}\text { S. Br. Raritan R. at } \\
\text { Middle Valley, N.J. }\end{array}$ & 47.6 & $\begin{array}{l}01396500 \\
01399500\end{array}$ & $\begin{array}{l}.9951 \\
.9927\end{array}$ & $\begin{array}{l}\mathrm{QP}_{\mathrm{R}}=0.71008 \\
\mathrm{QP}_{\mathrm{R}}=3.25136\end{array}$ & $\begin{array}{l}\mathrm{QI}^{(0.9961)} \\
Q I^{(0.7955)}\end{array}$ & $\begin{array}{l}61.9 \\
63.6\end{array}$ & $\overline{62.75}$ \\
\hline 01396350 & $\begin{array}{l}\text { S. Br. Raritan R. at } \\
\text { Califon, N.J. }\end{array}$ & 58.5 & $\begin{array}{l}01396500 \\
01399500\end{array}$ & $\begin{array}{l}.9052 \\
.8438\end{array}$ & $\begin{array}{l}\mathrm{QP}_{\mathrm{R}}=0.21046 \\
\mathrm{QP}_{\mathrm{R}}=1.89971\end{array}$ & $\begin{array}{l}Q I^{(1.3103)} \\
Q I^{(0.9855)}\end{array}$ & $\begin{array}{l}75.1 \\
75.6\end{array}$ & $\overline{75.35}$ \\
\hline 01396590 & $\begin{array}{l}\text { Spruce Run near High } \\
\text { Bridge, N.J. }\end{array}$ & 15.5 & $\begin{array}{l}01396500 \\
01399500\end{array}$ & $\begin{array}{l}.9817 \\
.9664\end{array}$ & $\begin{array}{l}\mathrm{QP}_{\mathrm{R}}=0.03454 \\
\mathrm{QP}_{\mathrm{R}}=0.19724\end{array}$ & $\begin{array}{l}Q I^{(1.3256)} \\
Q I^{(1.1728)}\end{array}$ & $\begin{array}{l}13.2 \\
15.8\end{array}$ & $\overline{14.5}$ \\
\hline
\end{tabular}


Table 8. Average base flow and results of low-flow-correlation analysis for 21 partial-record measurement sites in the study area - continued

\begin{tabular}{|c|c|c|c|c|c|c|c|c|}
\hline $\begin{array}{l}\text { Partial- } \\
\text { record } \\
\text { station } \\
\text { number }\end{array}$ & $\begin{array}{l}\text { Partial-record- } \\
\text { station name }\end{array}$ & $\begin{array}{c}\text { Drainage } \\
\text { area } \\
\left(\mathrm{mi}^{2}\right)\end{array}$ & $\begin{array}{l}\text { Continuous- } \\
\text { record- } \\
\text { station } \\
\text { number }\end{array}$ & $\begin{array}{l}\text { Correlation } \\
\text { coefficient }\end{array}$ & \multicolumn{2}{|c|}{$\begin{array}{l}\text { Correlation } \\
\text { equation }{ }^{1}\end{array}$} & $\begin{array}{c}\text { Estimated } \\
\text { base flow } \\
\mathrm{QP}_{\mathrm{R}} \\
\left(\mathrm{ft}^{3} / \mathrm{s}\right)\end{array}$ & $\begin{array}{c}\text { Average of } \\
\text { estimated } \\
\text { base flows } \\
\left(\mathrm{ft}^{3} / \mathrm{s}\right)\end{array}$ \\
\hline \multirow[t]{2}{*}{01398220} & India Brook near & 4.36 & 01396500 & .9513 & $\mathrm{QP}_{\mathrm{R}}=0.00221$ & $\mathrm{QI}^{(1.7632)}$ & 6.0 & -- \\
\hline & Mendham, N.J. & & 01399500 & .9628 & $\mathrm{QP}_{\mathrm{R}}=0.03321$ & $Q I^{(1.4031)}$ & 6.3 & 6.15 \\
\hline \multirow[t]{2}{*}{01398360} & Burnett Brook near & 6.64 & 01396500 & .9830 & $\mathrm{QP}_{\mathrm{R}}=0.04816$ & $\mathrm{QI}^{(1.1664)}$ & 9.0 & -- \\
\hline & Chester, N.J. & & 01399500 & .9605 & $\mathrm{QP}_{\mathrm{R}}=0.41777$ & $Q I^{(0.8206)}$ & 9.0 & 9.0 \\
\hline \multirow[t]{2}{*}{01399190} & Lamington River at & 7.37 & 01396500 & .9239 & $\mathrm{QP}_{\mathrm{R}}=0.03464$ & $Q I^{(1.2273)}$ & 8.5 & - \\
\hline & Succasunna, N.J. & & 01399500 & .9374 & $\mathrm{QP}_{\mathrm{R}}=0.30309$ & $Q I^{(0.8901)}$ & 8.4 & 8.45 \\
\hline \multirow[t]{2}{*}{01399194} & Succasunna Brook at & 1.72 & 01396500 & .8094 & $\mathrm{QP}_{\mathrm{R}}=0.0001769$ & $\mathrm{QI}^{(2.0244)}$ & 1.6 & - \\
\hline & Succasunna, N.J. & & 01399500 & .8788 & $\mathrm{QP}_{\mathrm{R}}=0.00551$ & $Q I^{(1.4826)}$ & 1.4 & 1.5 \\
\hline \multirow[t]{2}{*}{01399192} & Lamington $R$. Trib. near & 0.64 & 01396500 & 0.9504 & $\mathrm{QP}_{\mathrm{R}}=0.0000264$ & $\mathrm{QI}^{(2.2388)}$ & 0.6 & - \\
\hline & Ironia, N.J. & & 01399500 & .9500 & $\mathrm{QP}_{\mathrm{R}}=0.00137$ & $Q 1^{(1.6046)}$ & .6 & .6 \\
\hline \multirow[t]{2}{*}{01399200} & Lamington River near & 10.9 & 01396500 & .907 & $\mathrm{QP}_{\mathrm{R}}=0.06929$ & $Q I^{(1.1644)}$ & 12.8 & -- \\
\hline & Ironia, N.J. & & 01399500 & .9484 & $\mathrm{QP}_{\mathrm{R}}=0.42296$ & $Q I^{(0.9192)}$ & 13.1 & 12.95 \\
\hline \multirow[t]{2}{*}{01399280} & Lamington River near & 17.3 & 01396500 & .9853 & $\mathrm{QP}_{\mathrm{R}}=0.00813$ & $Q I^{(1.7688)}$ & 22.7 & -- \\
\hline & Chester, N.J. & & 01399500 & .9707 & $\mathrm{QP}_{\mathrm{R}}=0.0938$ & $\mathrm{QI}^{(1.4918)}$ & 24.8 & 23.75 \\
\hline \multirow[t]{2}{*}{01399300} & Lamington River at & 23.2 & 01396500 & .7673 & $\mathrm{QP}_{\mathrm{R}}=0.11047$ & $Q I^{(1.2815)}$ & 34.6 & -- \\
\hline & Milltown, N.J. & & 01399500 & .8162 & $\mathrm{QP}_{\mathrm{R}}=0.93492$ & $\mathrm{QI}^{(0.9841)}$ & 37.0 & 35.8 \\
\hline \multirow[t]{2}{*}{01399510} & Upper Cold Brook near & 2.18 & 01396500 & .9276 & $\mathrm{QP}_{\mathrm{R}}=0.00284$ & $Q I^{(1.4789)}$ & 2.2 & - \\
\hline & Pottersville, N.J. & & 01399500 & .8992 & $\mathrm{QP}_{\mathrm{R}}=0.03751$ & $\mathrm{QI}^{(1.0929)}$ & 2.2 & 2.2 \\
\hline
\end{tabular}

${ }^{1}$ Average base flow at index station (Q1) for water year 1988 used in equations are as follows:

station $01379700,38.1 \mathrm{ft}^{3} / \mathrm{s}$;

station $01396500,88.7 \mathrm{ft}^{3 /}$;

station $01399500,42.0 \mathrm{ft}^{3} / \mathrm{s}$. 
River at Berkshire Valley (01379700) were correlated with low flows at the the partial-record station on the Rockaway River near Wharton (01379710) and with the partial-record station on the Rockaway River at Dover (01379740). Average recent (1988) base flow at two streamflow-gaging stations on Green Pond Brook was calculated directly by using hydrograph-separation techniques of Sloto (1988).

Base-flow estimates were used to determine base-flow gains along several stream reaches; however, base flow represented by these estimates includes wastewater return flows and throughflow from upland tributaries entering the reach between streamflow-measurement stations. Therefore, the amount of the base-flow gain derived from the valley-fill and carbonate-rock aquifer system for a particular reach was determined by taking the difference between estimated base flow at the stations defining the reach and adjusting this difference downward to account for wastewater return flows and throughflow. The equation used is

$$
B_{g}=B_{d}-\left(U-S_{L}\right)-W \text {, }
$$

where $B_{g}=$ actual base-flow gain over the length of a reach derived from the aquifer system,

$B_{d}=$ difference between estimates of average base flow at an upstream site and average base flow at a downstream site over the length of a reach,

$\mathrm{U}=$ sum of flows of upland tributaries that enter the reach,

$\mathrm{S}_{\mathrm{L}}=$ streamflow loss from upland tributaries to the aquifer system,

$\left(U-S_{L}\right)=$ throughflow, and

$\mathrm{W}=$ wastewater return flow discharged directly to the reach or its tributaries.

Table 9 lists the values for each of these terms for eight stream reaches and explains how values of upland base flow and streamflow losses were determined.

Actual base-flow gains $(\mathrm{Bg})$ in these reaches define the distribution of ground-water discharge to streams from the aquifer system. This distribution was an important calibration target in simulating flow within the system. The eight stream reaches were selected to compare observed and simulated base-flow gains (fig. 38). Observed and simulated long-term average base-flow gains are listed in table 9. The accuracy of the estimates of base-flow gains are limited by the accuracy of estimates of throughflow and return flows. This limitation should be considered in comparing observed and simulated base flows. One of the criteria used in calibrating the model was to match simulated base-flow gains closely to observed gains in reaches for which base-flow reduction is a particular concern. These reaches are, in order of calibration priority, Drakes Brook between Reger Road and Bartley (reach 6), South Branch Raritan River above Califon (reach 7), and the Lamington River above Ironia (reach 3 ). The difference between simulated and observed base-flow gains was 9 percent or less for reaches 6 and 3 . The difference was greater for reach 7; however, the match must be evaluated in consideration of the accuracy of the large rate of inflow $\left(22.5 \mathrm{ft}^{3} / \mathrm{s}\right)$ along this reach from upland tributaries, which limits the accuracy of the observed base-flow gain for this reach. Some of the $40.7 \mathrm{ft}^{3} / \mathrm{s}$ measured flow gain (perhaps a few cubic feet per second) may be incorrectly attributed to higher inflow from upland tributaries rather than to actual ground-water discharge from the aquifer system. In consideration of this possibility, the match is considered acceptable.

The large absolute difference of $7.15 \mathrm{ft}^{3} / \mathrm{s}$ between simulated and observed gains in the Lamington River between Milltown and Ironia (reach 4) may be the combined result of uncertainty in the estimate of observed base flow and error in the simulated distribution of recharge in the areas adjacent to that reach. It is possible that extensive wetland areas flanking this reach may temporarily detain surface runoff, such that measured low flows include a substantial proportion of surface runoff. This condition would lead to the overestimation of base flow from field data.

A particular advantage of using a calibrated flow model to evaluate the ground-water budget of a complex flow system is the ability of the model to define the distribution of flows between aquifers within the system and to quantify each component of the ground-water budget for each aquifer. The simulated ground-water budget provides a coherent definition of the distribution of flows within the system that is 
[All flow values in cubic feet per second]

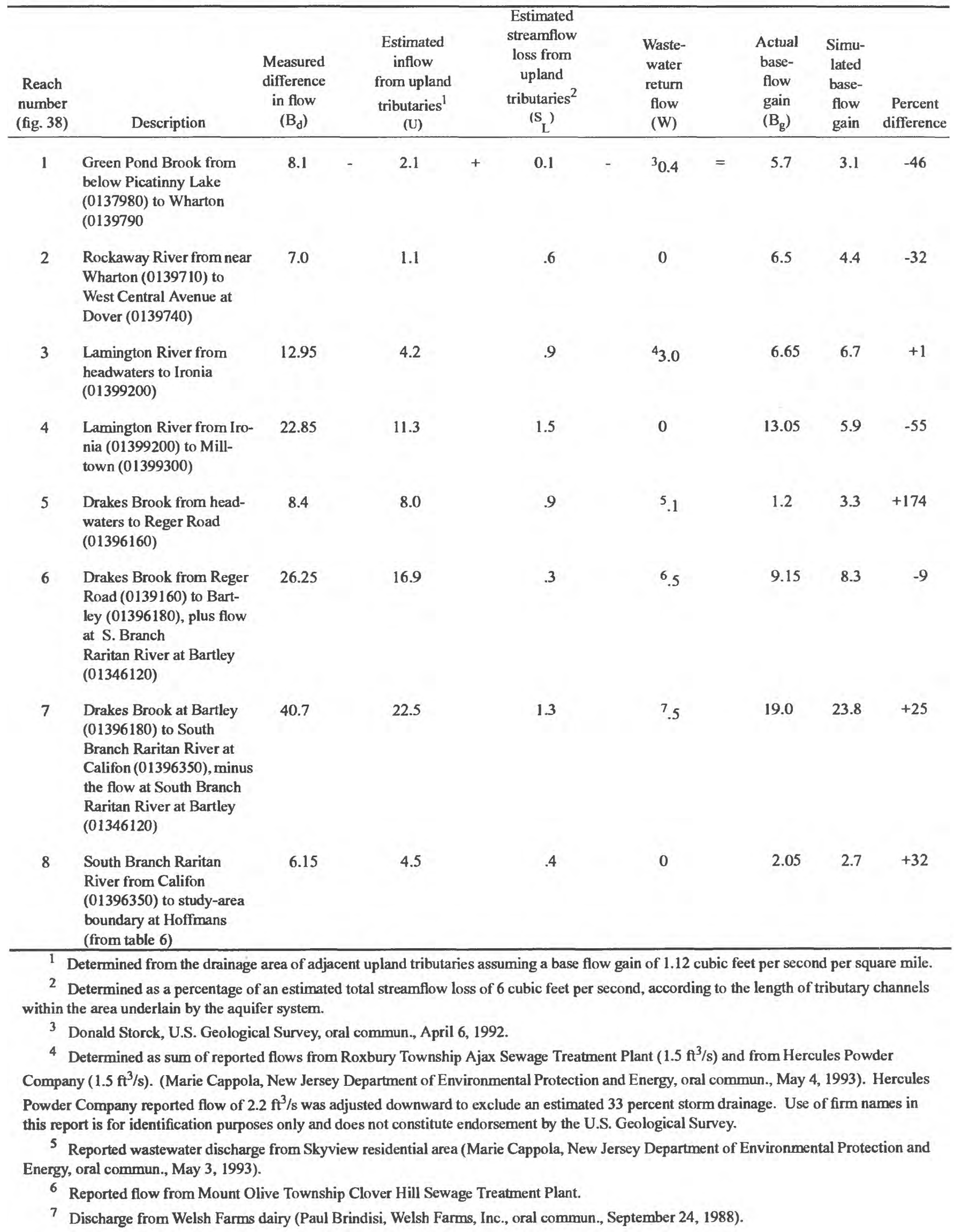




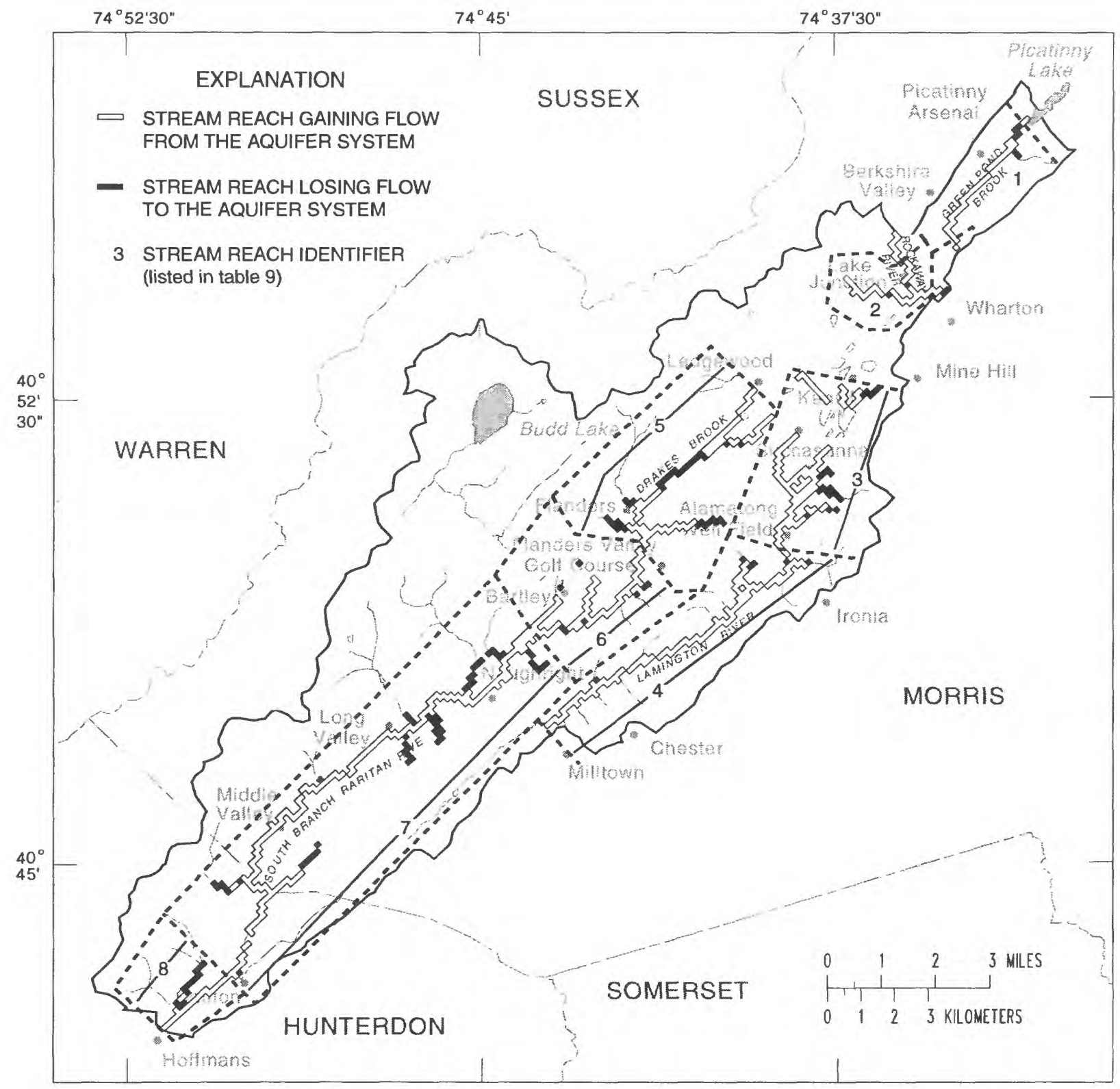

Figure 38. Stream reaches with simulated gains or losses of flow from or to the aquifer system, and locations of stream reaches for which simulated base-flow gains were compared with measured gains. 
consistent with the concepts of system geometry, hydrologic boundaries, parameter distributions, and other stresses that are integrated in the model representation of the system. The simulated water budget under recent, steady conditions for the entire model is shown in figure 39. Recharge from infiltration of direct precipitation and from unchanneled runoff from upland areas is $62.1 \mathrm{ft}^{3} / \mathrm{s}$; it enters the system through the outcrop areas of all three aquifers-the upper valley-fill aquifer, the lower valley-fill aquifer, and the carbonate- rock aquifer. An additional $5.9 \mathrm{ft}^{3} / \mathrm{s}$ recharges the system as leakage from surface water, bringing the total simulated recharge to $68 \mathrm{ft}^{3} / \mathrm{s}$. This value agrees closely with the total recharge estimate of $70 \mathrm{ft}^{3} / \mathrm{s}$ made earlier. An additional simulated inflow of $1.2 \mathrm{ft}^{3} / \mathrm{s}$ as net flux from adjacent buried valleys makes up most of this difference.

Ground water flows through leaky and discontinuous confining units to discharge at pumped wells or surface-water bodies. Downward leakage from the upper valley-fill aquifer to the underlying aquifers is $6.8+1.4=8.2 \mathrm{ft}^{3} / \mathrm{s}$. Downward leakage from the lower valley-fill aquifer to the carbonate-rock aquifer is $8.3 \mathrm{ft}^{3} / \mathrm{s}$. The extents and permeabilities of the confining units control flow directions and contributing areas to wells and streams. The total pumpage of $7.2 \mathrm{ft}^{3} / \mathrm{s}(4.7 \mathrm{Mgal} / \mathrm{d})$ is distributed among all three aquifers, but most of the pumpage is from confined parts of the lower valley-fill aquifer and confined parts of the carbonate-rock aquifer. Flow is contributed to wells from stream leakage and from capture of ground water that would otherwise discharge to surface-water bodies. Total ground-water discharge to streams is $61.8 \mathrm{ft}^{3} / \mathrm{s}$. Total leakage from surface-water bodies is $5.9 \mathrm{ft}^{3} / \mathrm{s}$, some of which occurred during prepumping conditions and some of which occurs in response to recent pumping.

\section{Ground-Water Levels and Flow Directions}

Water levels were measured during synoptic water-level surveys to represent recent, average conditions and were contoured to produce a water- table or potentiometric-surface map of each aquifer. Surveys were conducted in May 1988 (75 wells), September 1988 (169 wells), April 1989 (236 wells), and September 1989 (109 wells). The results of these surveys provided a basis for formulating basic concepts of the flow system and for determining the approximate magnitude of seasonal fluctuations.

The survey in April 1989, which included the measurement of water levels in test wells drilled by the USGS, provided the primary data base for interpreting water levels in aquifers. Results of the survey in September 1989 were used to evaluate changes in the flow field over the period of study; this survey included wells that had been previously inaccessible. Where water levels were not available for April 1989 or September 1989, water levels measured during the other surveys were used as a guide in preparing water-table and the potentiometric-surface maps. Together, the synoptic water-level surveys provide a comprehensive data base for ground- water-level and flow-direction information. Generalized groundwater flow directions in the upper valley-fill, lower valley-fill, and carbonate-rock aquifers, as inferred from these surveys, are shown in figures 30,31 , and 32 , respectively.

The water levels measured during 1989 water-level surveys are considered representative of average or near-average conditions during 1988- 89. The average water level during 1988-90 and the range of water levels measured during the four water-level surveys in an observation well open to the valley-fill aquifer system are illustrated in figure 40a. The average water level during 1988-91 and the range of water levels measured during the four water-level surveys in an observation well open to the carbonate-rock aquifer are shown in figure $40 \mathrm{~b}$. Among the 41 wells in which water levels were measured in both May 1988 and September 1988, the measured water-level change ranged from -8.9 to $5.6 \mathrm{ft}$. The median change was $-1.3 \mathrm{ft}$, and in all but 7 wells, the water level declined by $4 \mathrm{ft}$ or less. Water-level fluctuations in selected wells measured monthly are discussed later. The narrow range in fluctuations provides a further indication that water levels measured during synoptic surveys are representative of recent, average conditions.

Results of a simulation of recent steady-flow conditions were compared to the field data to interpret further the potentiometric surface of each aquifer and the principal flow directions in the aquifer system. 


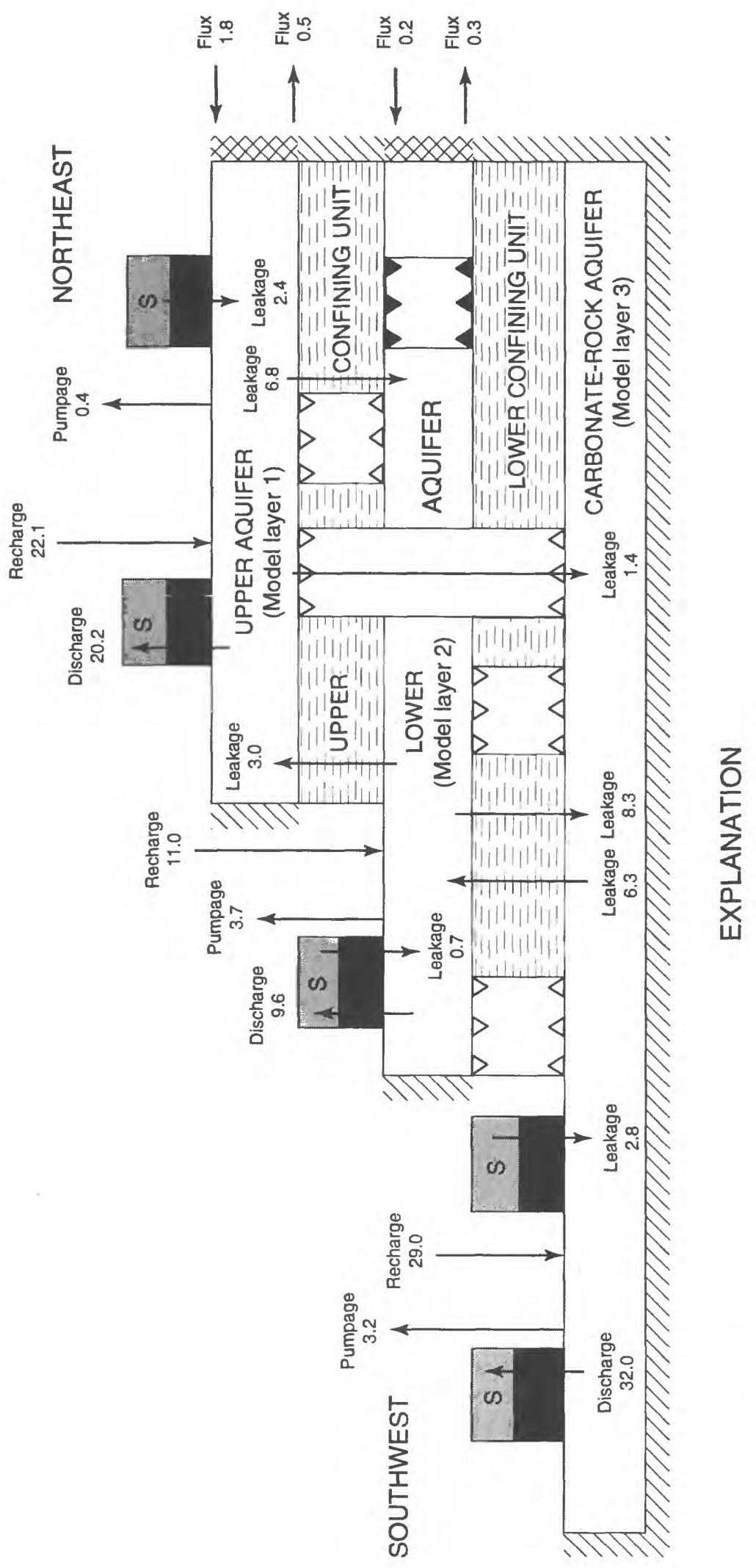

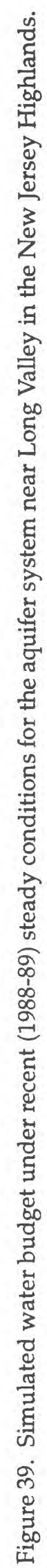



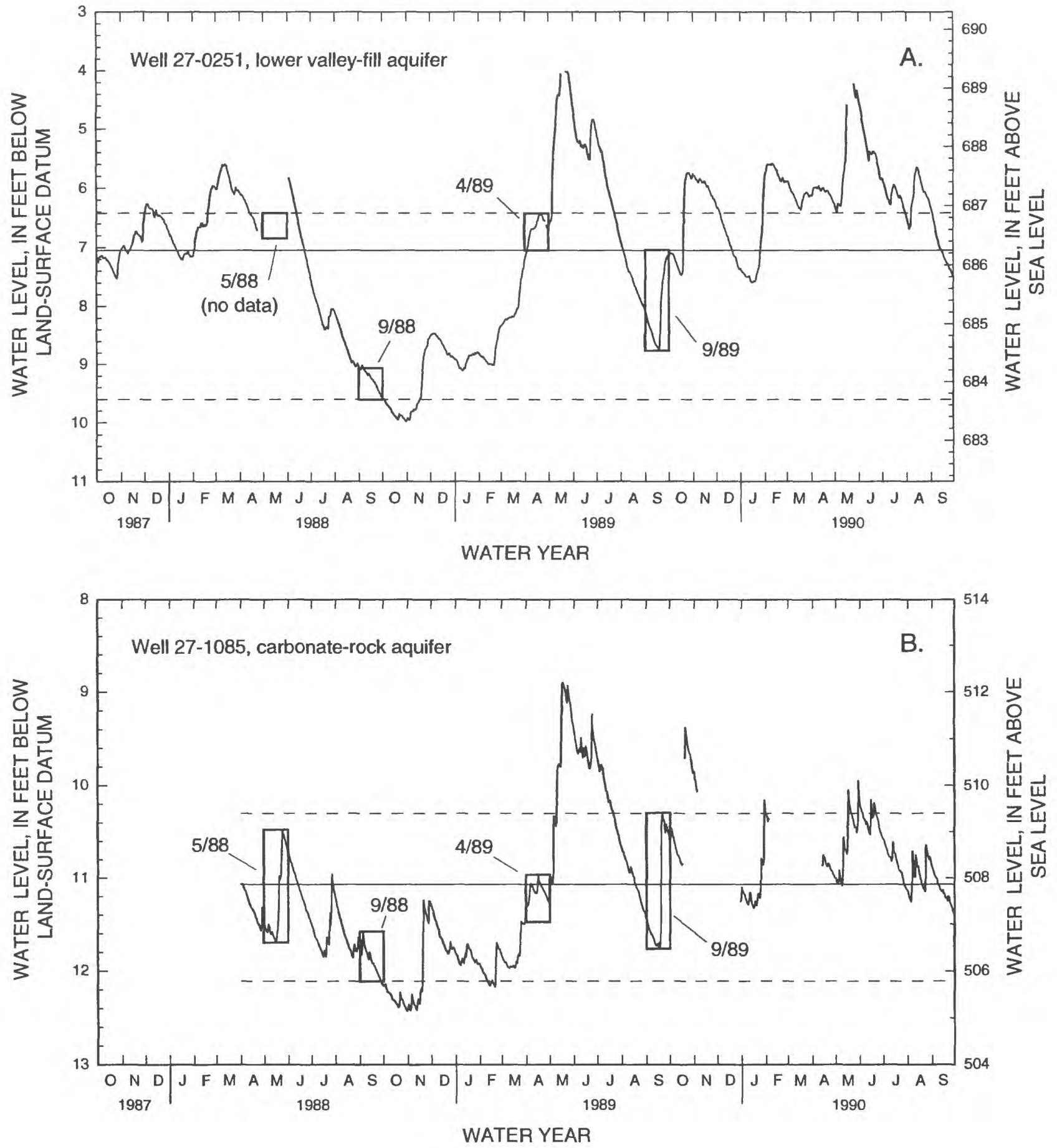

EXPLANATION

$\square \quad \begin{aligned} & \text { Synoptic water-level } \\ & \text { survey period }\end{aligned}$
$\quad$ Mean water level

Figure 40. Relation between mean water level during recent period and water levels during synoptic surveys of the aquifer system near Long Valley in the New Jersey Highlands. 
The altitudes of average 1988-89 water levels within the upper valley-fill aquifer are shown on plate $2 a$, and simulated water levels are shown on plate $2 b$. Altitudes of average 1988-89 water wells within the lower valley- fill aquifer and simulated water levels are shown on plates $2 \mathrm{c}$ and $2 \mathrm{~d}$, respectively. Altitudes of average 1988-89 water levels within the carbonate-rock aquifer and simulated water levels are shown on plates $3 \mathrm{a}$ and $3 \mathrm{~b}$, respectively. On plates $2 \mathrm{a}, 2 \mathrm{c}$, and $3 \mathrm{a}$, arrows indicate the direction of the horizontal component of ground-water flow in the aquifer. The horizontal component of flow in the carbonaterock aquifer is not strictly perpendicular to contour lines as a result of the lateral anisotropy of the carbonate-rock aquifer with respect to hydraulic conductivity.

The simulated water-level-surface contours can be compared with those constructed manually from measured control data shown on the same sheets. The similarity between the manually interpreted and simulated surfaces and the gradients defined by these surfaces supports the plausibility of both the model representation of the flow system and the manual interpretation of the water-level surfaces. Simulated water-level-surface contours were generated by using the computer program of Harbough (1990a) and then processed for analysis and plotting by using a geographic information system. The distribution of head residuals (simulated-head altitude minus observed-head altitude) also is shown on plates $2 \mathrm{~b}, 2 \mathrm{~d}$, and $3 \mathrm{~b}$. Residual values are considered acceptably low in relation to the accuracy of the interpreted potentiometric surfaces and also in consideration of modeling objectives; relatively large differences (as much as $15 \mathrm{ft}$ for valley-fill aquifers and $20 \mathrm{ft}$ for the carbonate-rock aquifer) between simulated and manually interpreted head distributions are considered acceptable in special situations, such as in areas where the configuration of the potentiometric surface is uncertain (dashed lines on plates $2 a, 2 c$, and 3a), provided that simulated gradients are reasonably consistent with manually interpreted gradients. Other factors, such as limitations of model discretization and proximity of wells to hydrologic boundaries, also were considered in evaluating the acceptability of head residuals.

\section{Upoer valley-fill aquifer}

The water-table contours for the upper valley-fill aquifer (pl. 2a) generally indicate natural sources of recharge to and discharge from the aquifer. Areas where the water table is highest indicate areas of aquifer recharge. A water-table contour that crosses a gaining stream forms a "V" that points upstream and indicates that the aquifer is discharging flow to the stream at that location-for example, near Ironia (pl. 2a, $2 b$ ). Where the aquifer is recharged by infiltrating streamflow, the water-table contour forms a " $V$ " pointing downstream where it crosses the stream. This is the case near valley walls where small tributary streams flow from upland areas of higher altitude onto stratified-drift outcrop areas where the water-table altitude is lower than the stream stage. Ground water in the upper valley-fill aquifer generally flows toward local surface-water bodies, downvalley near the centers of the valleys, and downward into underlying aquifers.

Measured and simulated water levels and head gradients in the upper valley-fill aquifer compare favorably. The differences between simulated and measured water levels in 18 wells tapping the upper valley-fill aquifer ranged from $-6.7 \mathrm{ft}$ to $15.2 \mathrm{ft}$. The median difference was $7.0 \mathrm{ft}$. Most of the wells with highest positive residuals are clustered together. Seventy-five percent of the absolute differences ( 14 wells) were less than $9.6 \mathrm{ft}$. The location of the highest absolute difference, $15.2 \mathrm{ft}$, is a well in the stratified sediment of the Wisconsinan terminal moraine (27-1664), where the measured unconfined head of $673 \mathrm{ft}$ is not appreciably higher than the stage of the adjacent Rockaway River about 2,500 ft to the east. The difficulty in simulating heads this low in this area indicates that highly permeable, buried stratified sediments within the terminal moraine could be discharging ground water to the Rockaway River further downstream at a lower stage. This explanation is speculative, however, and did not warrant changing framework concepts. Measured and simulated head gradients trend in a direction between downvalley and crossvalley, and measure about $10 \mathrm{ft} / \mathrm{mi}(0.002)$ at Succasunna and slightly higher to the north. 


\section{Lower valley-fill aquifer}

The lower valley-fill aquifer is confined over most of its extent (fig. 31). The hydrogeologic framework in the transition areas between the confined and unconfined portions is poorly understood; two distinct valley- fill aquifers are clearly present north of the transition areas, and only one extensive, waterbearing valley-fill unit is present south of the transition areas. Flow patterns in these transition areas may be complex.

The contours on plate $2 c$ show the effects of pumpage and of leakage to the carbonate-rock aquifer on water levels in the lower valley-fill aquifer. Water levels around pumping centers at Kenvil and near Ironia are markedly lower than in the overlying aquifer. Water levels also are depressed in Succasunna and along Drakes Brook between Ledgewood and Flanders as a result of leakage to the underlying carbonaterock aquifer. In the Flanders area, the lower valley-fill aquifer is unconfined and ground water follows short flow paths to Drakes Brook or is captured as leakage to the carbonate-rock aquifer (pl. 1e). North of Kenvil, ground water in the lower valley-fill aquifer flows toward the Rockaway River.

Measured and simulated water levels and head gradients compare favorably. The differences between simulated and measured water levels in 31 wells tapping the lower valley-fill aquifer ranged from -13.8 to $15.1 \mathrm{ft}$. The median difference was $1.8 \mathrm{ft}$. Seventy-five percent of the absolute differences ( 24 wells) were less than $7.2 \mathrm{ft}$. Measured and simulated head gradients typically were 30 to $50 \mathrm{ft} / \mathrm{mi}(0.006-0.01)$ at Flanders, and were more variable to the north. The lowest measured and simulated gradients were less than $10 \mathrm{ft} / \mathrm{mi}(<0.002)$, at Succasunna.

Vertical leakage between aquifers was determined from the results of simulations. Figure 41 shows directions of vertical leakage through the bottom of aquifer layer 1. Simulated upward leakage from the lower valley- fill aquifer (layer 2 ) to the upper valley-fill aquifer (layer 1) near the Rockaway River and Green Pond Brook shows the effect of these rivers as sinks for flow in the lower valley-fill aquifer. The other areas of downward flow show the effect of lower heads in the lower valley-fill aquifer than in the upper valley-fill aquifer, notably at the Alamatong well field.

\section{Carbonate-rock aquifer}

The carbonate-rock aquifer is unconfined in some areas and is confined by glacial sediments in others (fig. 32). In the southern part of the study area, where much of the carbonate-rock aquifer is unconfined, the water- level contours on plate $3 a$ indicate flow toward surface-water features, as in the unconfined valley-fill aquifers to the north. In the northern part of the study area, where the carbonate-rock aquifer is confined, water-level contours indicate flow directions that are controlled by leakage from overlying aquifers, contrasts in hydraulic conductivity, and pumpage. Beneath the Paleozoic confining unit, the carbonate-rock aquifer is believed to be less permeable than elsewhere as a result of the deposition of the materials that formed the confining unit. The presence of these poorly sorted, relatively impermeable confining-unit materials may have impeded recharge to the underlying carbonate-rock aquifer and consequently retarded the development of secondary-permeability features. A permeability contrast between the carbonate rock overlain by the Paleozoic confining unit and that overlain by valley-fill sediment is hypothesized on the basis of the head gradients; heads are higher (650-720 ft above sea level) in the carbonate- rock aquifer underlying Drakes Brook northwest of the Green Pond Conglomerate than in the carbonate-rock aquifer just southeast of the conglomerate, where they are 600 to $670 \mathrm{ft}$ above sea level (pl. 3a). The contrast in heads within the carbonate-rock aquifer on either side of the overlying conglomerate indicates the presence of a low-permeability zone between these two areas. Downvalley flow probably is concentrated within the carbonate-rock aquifer along the sides of the conglomerate, and little flow probably crosses between the zones within the low-permeability rock beneath the conglomerate. 


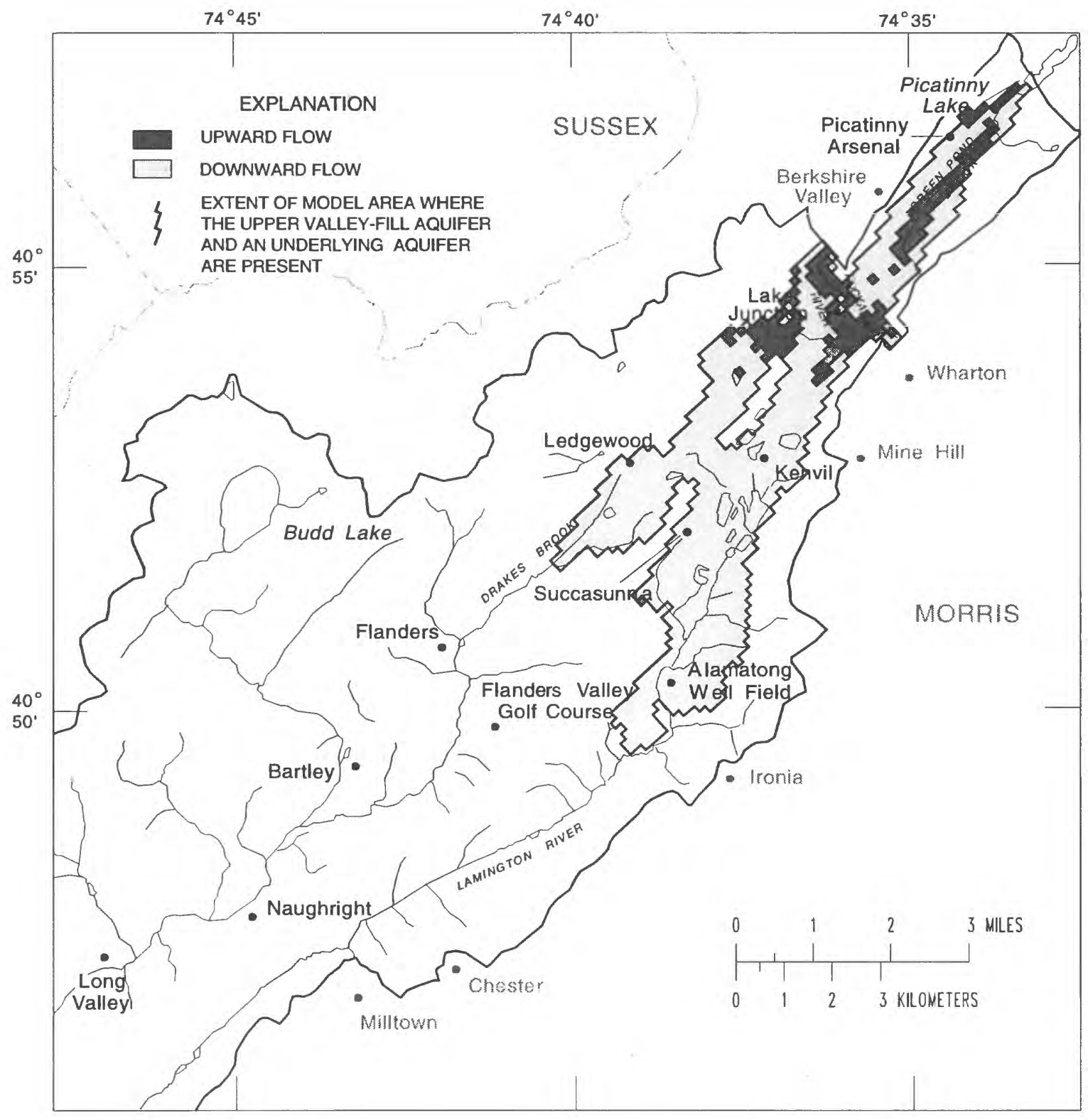

Figure 41. Simulated direction of flow across the bottom of the upper valley-fill aquifer under recent, steady conditions. 
Flow out of the Lamington River Basin into the South Branch Raritan River Basin near Succassunna is substantial. The potentiometric-surface contours show that flow that is not intercepted by pumpage at the Alamatong well field can be discharged from the aquifer only by continuing north and entering the South Branch Raritan River Basin, then flowing south toward the Flanders Valley golf course, where the aquifer hydraulic conductivity is exceptionally high and heads are very low. This is a natural occurrence of ground water flow from one surface-water basin to another. The diverted ground water ultimately discharges to the South Branch Raritan River at Bartley and southward.

Measured and simulated water levels and gradients in the carbonate-rock aquifer compare favorably. The differences between simulated water levels and water levels measured in 77 wells tapping the carbonate-rock aquifer ranged from -19.2 to $19.1 \mathrm{ft}$. The median difference was $1.0 \mathrm{ft}$. Seventy-five percent of the absolute differences ( 58 wells) were less than $9.5 \mathrm{ft}$. Many of the larger absolute differences between simulated and measured water levels were in areas of relatively large hydraulic gradients, where model discretization limits the accuracy of simulated heads at specific locations.

Measured and simulated head gradients in the crossvalley direction were similar, and exceeded $160 \mathrm{ft} / \mathrm{mi}(>0.03)$ in some areas in the southern part of the study area and in some areas where the hydraulic conductivity of the carbonate-rock aquifer is expected to be very low. Measured and simulated head gradients in the downvalley direction also compare favorably, and were less than $10 \mathrm{ft} / \mathrm{mi}(<0.002)$ at Flanders and at Kenvil. Simulated vertical leakage through the bottom of the lower valley-fill aquifer (layer 2) (fig. 42) shows the effects of pumpage from the lower valley-fill aquifer on flow in the carbonate-rock aquifer (layer 3). Upward flow is simulated at the Alamatong well field near Morris County Municipal Utilities Authority pumped well \#4, and near the pumped wells at Kenvil and Picatinny Arsenal, as a result of pumping from the lower valley-fill aquifer. It is also evident from these figures that the Rockaway River in the north and the South Branch Raritan River in the south near Bartley are sinks for flow from the carbonate-rock aquifer through the lower valley-fill aquifer. The remaining areas show downward flow, indicating that the carbonate-rock aquifer receives leakage from the overlying lower valley-fill aquifer over large areas.

\section{Recent Iransient Flow Conditions}

In this section, recent transient water-level responses to seasonal recharge variations and humaninduced stresses are interpreted. Analyses of transient responses observed during aquifer tests are presented, including results of transient simulation of the short-term aquifer-system response to pumping from the carbonate-rock aquifer.

\section{Water-Level Fluctuations}

Water levels were monitored during the course of the study in order to interpret water-level fluctuations at various locations in the three aquifers. Water-level hydrographs document trends in water levels and are useful in testing concepts about hydraulic interconnections and degree of confinement of different parts of the flow system.

Hydrographs of water levels in observation wells in relation to daily pumpage from the lower valley-fill aquifer and carbonate-rock aquifer illustrate the effect of the good hydraulic connection that exists between the two aquifers in the areas surrounding the Alamatong well field near Ironia. Figure 43 shows the hydrographs of observation wells 27-1125 and 27-1191 for November through December 1989, and also shows pumpage from a well open to the carbonate-rock aquifer (27-1090) and from a well open to the lower valley-fill aquifer (27-1324). The hydrograph of observation well 27-1125 shows recovery following the reduction in pumpage from the carbonate-aquifer well on November 12 and December 17 . The hydrograph of well 27-1191 shows recovery following reduction in pumpage from well 27-1324 on November 28, but recovery also is shown beginning on December 17, when pumping from the lower valley-fill aquifer continued. The recovery in this well coincides with the cessation of pumping from the well in the carbonaterock aquifer, indicating a good hydraulic connection between the two aquifers in this area. 


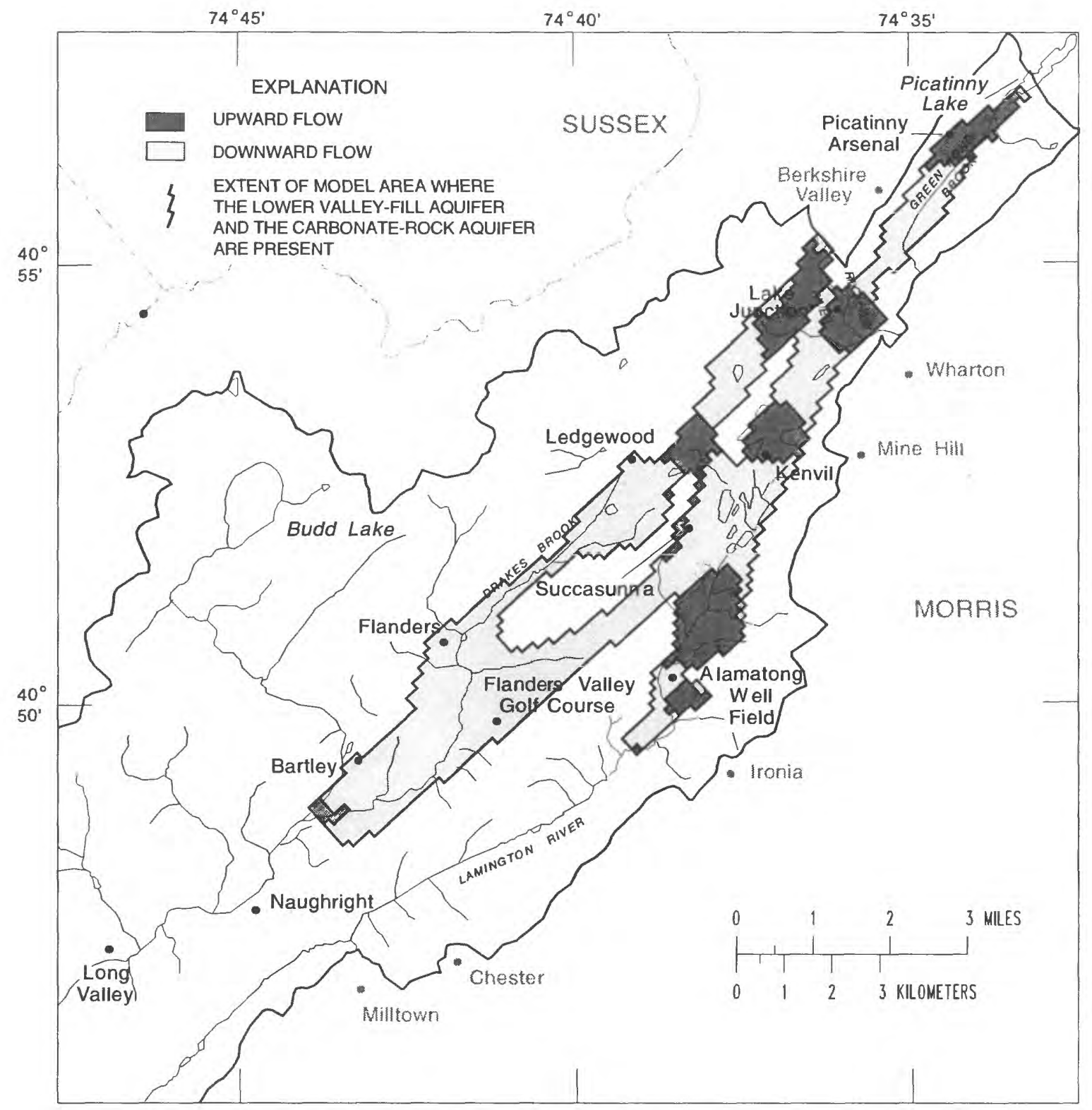

Figure 42. Simulated direction of flow across the bottom of the lower valley-fill aquifer under recent, steady conditions. 


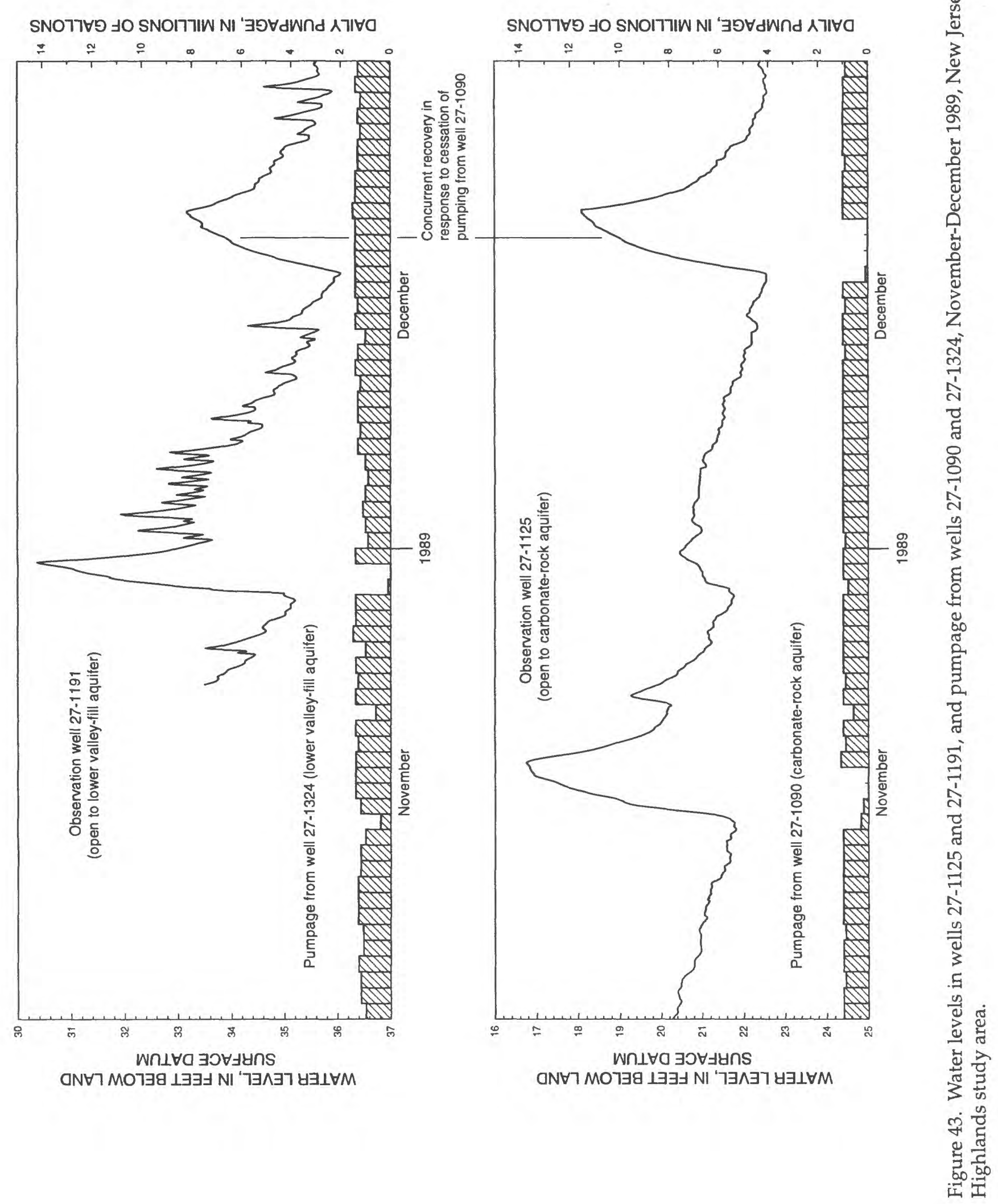


Two other hydrographs show that the water-transmitting properties of the carbonate-rock aquifer are continuous over large distances. Figure 44 shows the hydrographs of wells 27-1125 and 27-1123, both of which are open to the carbonate-rock aquifer, and daily pumpage from Alamatong well 5 (27-1090), open to the carbonate-rock aquifer. Well $27-1125$ is located 3,500 feet southeast of the pumped well (pl. 1a); its hydrograph shows distinct periods of drawdown and recovery in response to pumping from Alamatong well 5 . Well 27-1123 is located $4.3 \mathrm{mi}$ northeast of the pumped well; its hydrograph also shows a correlated response, though lower in magnitude and less distinct, to the same pumping cycles. The response in the more distant observation well appears to lag behind the response of the nearer well by about 2 days. The correlation of the responses of these two wells demonstrates the hydraulic continuity of the carbonate-rock aquifer over large distances.

In many areas south of Flanders, the carbonate-rock aquifer is unconfined or semiconfined, and is in good hydraulic connection with the South Branch Raritan River. Water levels in wells near the South Branch Raritan River fluctuate in response to bank storage of streamflow as well as to recharge, as indicated by frequent, abrupt rises in the water level coinciding with periods of high stream stage (Nicholson, 1990, p. N-29). Water levels measured in wells open to the carbonate-rock aquifer in the southern part of the study area fluctuate less than those in the northern part, where the aquifer is confined and affected to a greater extent by pumpage.

Hydrographs of eight other wells measured monthly during the study are shown in figures 45 and 46. The ranges of fluctuations in water levels in these wells typify the fluctuations for the respective locations and aquifers to which the wells are open. The hydrographs shown in figure 45 show fluctuations in four wells open to the carbonate-rock aquifer. The hydrographs are shown in order of increasing distance of the respective wells from the southwestern end of the study area, indicating a progression of increasing range in fluctuation with this distance. This increasing range of fluctuations is an indication of both the increasing degree of confinement of the carbonate-rock aquifer to the northeast and of the effects of higher rates of pumpage to the northeast.

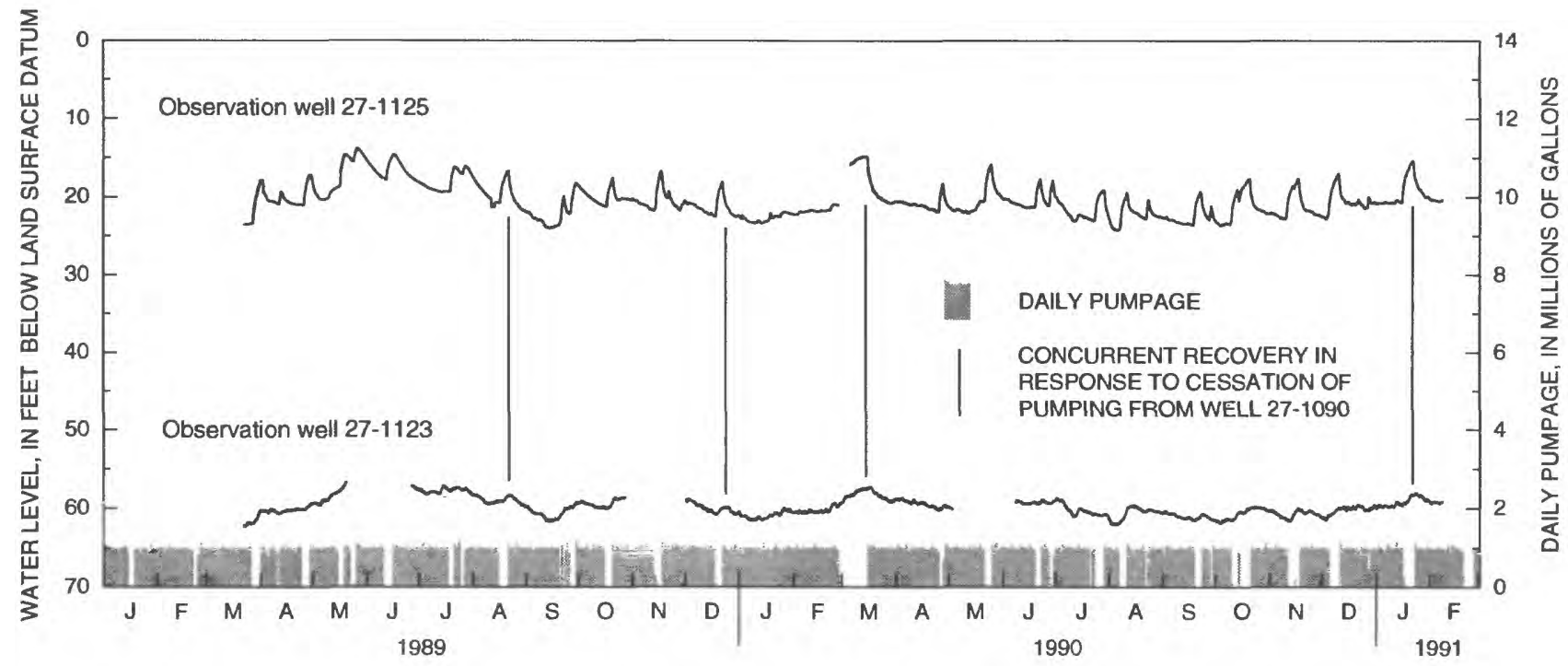

Figure 44. Water levels in wells 27-1123 and 27-1125, March 1989-February 1991, and pumpage from well 27-1090, January 1989-Februay 1991, New Jersey Highlands study area. 

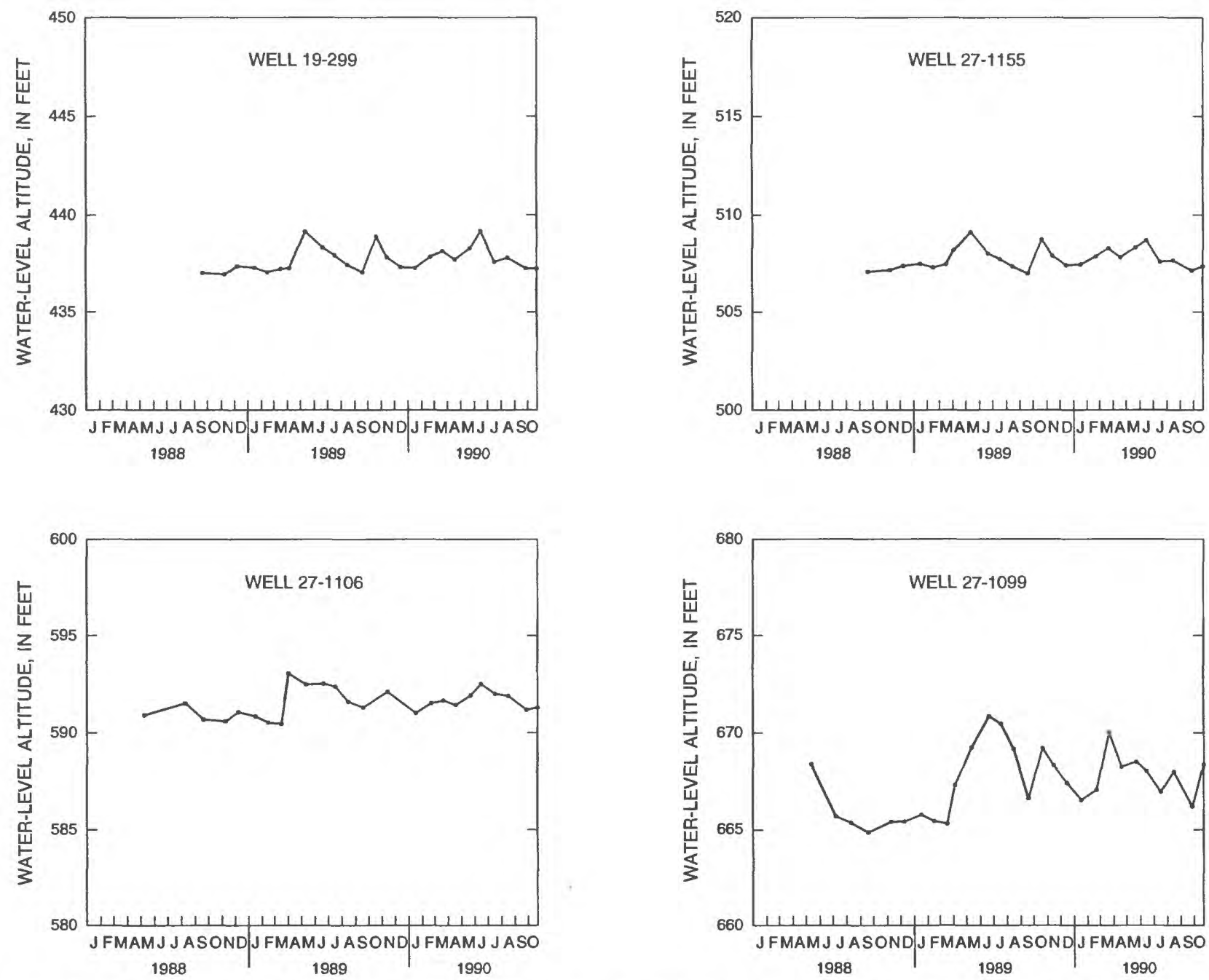

Figure 45. Water levels measured monthly in carbonate-rock aquifer wells 19-0299, 27-1106, 27-1155, and 27-1099, 1988-1990, New Jersey Highlands study area.

The hydrographs shown in figure 46 show fluctuations in four wells open to unconsolidated valley-fill sediments. Well 27-1121 is open to pre- Wisconsinan glacial till overlying the carbonate-rock aquifer, several miles south of the valley-fill aquifers, in a setting similar to that shown in section $A-A^{\prime}$ on plate $1 c$. The well is located near carbonate-rock aquifer well 27-1155 (fig. 45); the hydrographs for both wells are similar, indicting that the carbonate-rock aquifer and the overlying till may function together as a single water-bearing unit in this area.

Well 27-1098 is open to the lower valley-fill aquifer and is located in an area where two conditions may contribute to the large water-level fluctuations: (1) The aquifer is in good hydraulic connection with the underlying carbonate-rock aquifer, and a downward head gradient exists between them. Low head in the carbonate-rock aquifer during dry periods apparently results in low water levels in this well as leakage reduces storage in the lower valley-fill aquifer. (2) The well is located adjacent to a particularly steep hillslope that may be a source of high rates of recharge to the aquifer system during wet periods. High rates of recharge could explain the high water levels in this well.

Wells 27-1712 and 27-0921 are open to the lower valley-fill aquifer near Kenvil and Lake Junction, respectively. The respective hydrographs show similar ranges in fluctuations, in response to variations in leakage from the overlying aquifer and to variations in pumping rates of nearby wells. 

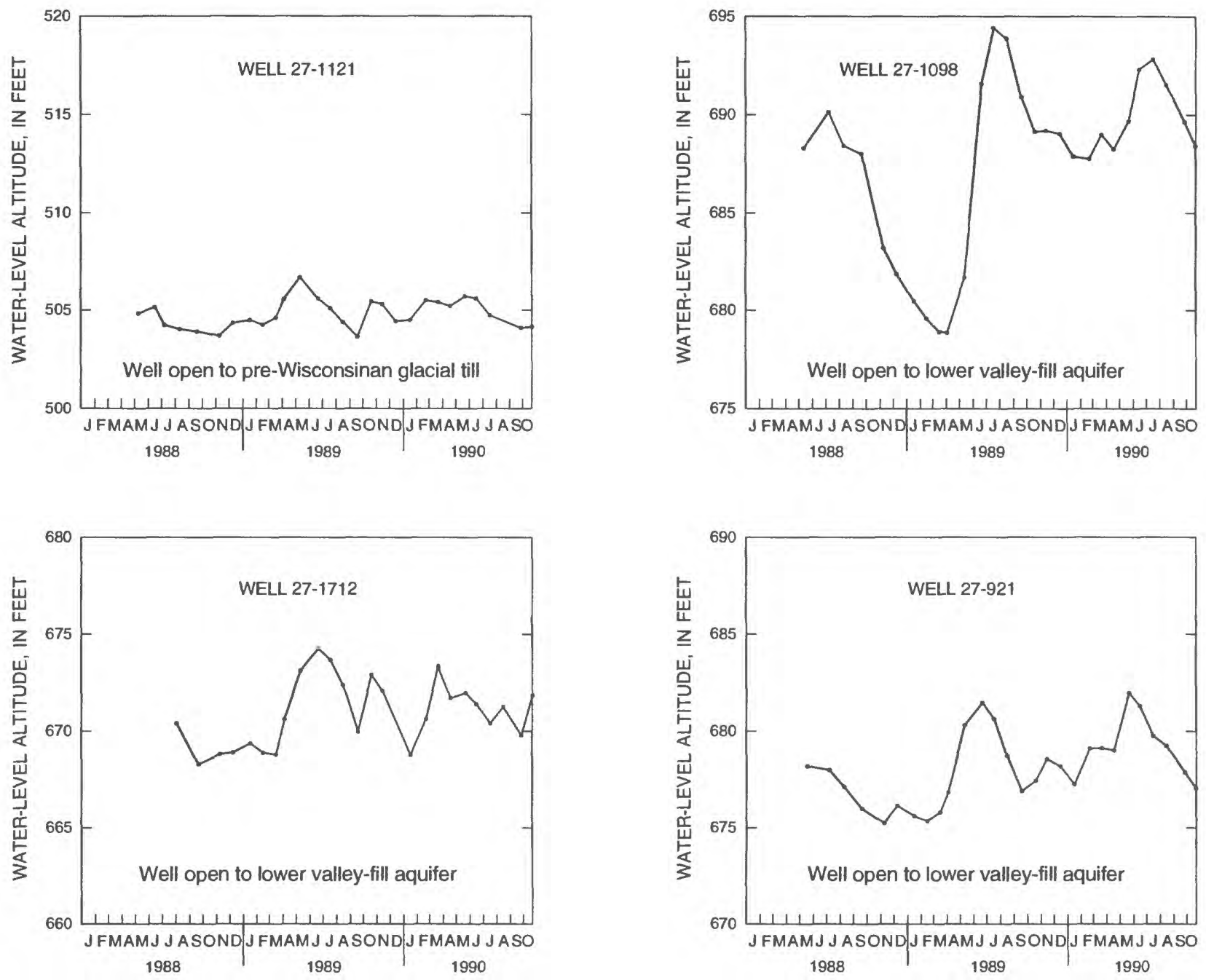

Figure 46. Water levels measured monthly in wells 27-1121, 27-1712, 27-1098, and 27-921, 1988-90, New Jersey Highlands study area.

Continuous hydrographs of several other wells in the study area are published in Bauersfeld and others (1991). The NJ-WRD numbers of these wells are listed below.

$\begin{array}{lll}27-1302 & 27-1128 & 27-1134 \\ 27-1303 & 27-1129 & 27-1135 \\ 27-1126 & 27-0250 & 27-0027 \\ 27-1164 & 27-0251 & 27-0242 \\ 27-1125 & 27-1130 & 27-0245 \\ 27-1084 & 27-1131 & 27-0095 \\ 27-1083 & 27-1133 & 27-0304 \\ 27-1124 & 27-1132 & 27-0028 \\ 27-1127 & & \end{array}$

The locations of these wells can be identified by means of these numbers on plate 1a.

\section{Aquifer Tests}

Concepts of the geometry, hydrologic boundaries, and distribution of hydraulic characteristcs of the flow system were tested by examining the transient response of the aquifer system to pumping from the carbonate-rock aquifer during aquifer tests. During a regional-scale test at Flanders, water-level responses were measured over an area of several square miles, which allowed an evaluation of these concepts as they apply to 
the large area affected by the large test stress. Numerical-modeling techniques were used to evaluate the results of the regional-scale test. Local-scale tests in other areas resulted in a smaller area of influence, and provided more site-specific indications of aquifer characteristics. The locations of the tests of the carbonaterock aquifer conducted during this study are shown in figure 11.

\section{Reaional-scale tests}

The Morris County Municipal Utilities Authority (MCMUA) FL1 test, conducted during September 18-24, 1990, at Flanders, New Jersey, provided a large regional stress to the aquifer system as a result of a high pumping rate. Several observation wells were monitored during the test, and the response of the water levels in these wells was simulated with the model. The success in matching simulated responses with measured responses provides assurance that the model representations of flow-system geometry, hydrologic boundaries, and aquifer characteristics over the area of influence are plausible.

The test was conducted in an area where the carbonate-rock aquifer is overlain and confined by a clayey residuum, gravel stringers, and pre-late Wisconsinan glacial till, similar to the area represented in section C-C' on plate 1e. The uppermost overburden deposits act as a separate water-bearing unit from the carbonate-rock aquifer in this area, although few wells draw from it. The water table within the overburden is about $40 \mathrm{ft}$ higher than the potentiometric surface of the carbonate-rock aquifer (see plates $2 \mathrm{c}$ and $3 \mathrm{a}$ ). At the base of the overburden, water levels are similar to those in the carbonate-rock aquifer.

The test, which was conducted by the MCMUA in cooperation with the USGS and the NJGS, was centered at the Flanders Valley Golf Course, where the pumped well (27-1728) is located (see fig. 11). The pumping rate was $2,000 \mathrm{gal} / \mathrm{min}$ for a period of $72 \mathrm{hours,} \mathrm{followed} \mathrm{by} \mathrm{a} 72$-hour recovery period. Water levels in several observation wells located at and near the golf course were monitored. These included wells open to the carbonate-rock aquifer, overlying gravel stringers, and the glacial till material of the lower valley-fill aquifer. At the golf course, the thickness of the carbonate-rock aquifer is estimated to be about $400 \mathrm{ft}$, thickening toward the synclinorium axis located along the center of the valley (Robert Canace, New Jersey Geological Survey, written commun., 1990). The overburden thickness at the site is about $300 \mathrm{ft}$.

Drawdown versus time divided by the square of the distance in six observation wells open to the carbonate-rock aquifer is shown in figure $47 \mathrm{a}$. The response curves are different from one another as a result of complex boundary conditions, heterogeneity, anisotropy, and other complicating factors. The effect of anisotropy is evident in the relation between the time lag in the drawdown curves and the orientation of the observation wells with respect to the pumped well. In general, the more closely the observationwell / pumped-well orientation parallels the valley axis, the less delayed the response, indicating a higher transmissivity parallel to the valley axis than perpendicular to it. The response of well 27-1308, which is oriented in a direction from the pumped well that is nearly perpendicular to the valley axis, was delayed relative to that of the other wells. These results indicate that the major and minor principal directions of the regional anisotropic transmissivity tensor are approximately down- and crossvalley, respectively.

Another aquifer test was conducted at the site in August 1990, in which a different well (27-1727) was pumped at the same rate of $2,000 \mathrm{gal} / \mathrm{min}$ for the same duration of 72 hours. The responses in the same observation wells generally were similar to those observed during the FL1 test, yet different in a way that corroborates the interpretation of anisotropy. Because of the different location of the pumped well, the orientations of the observation wells with respect to the pumped well were shifted to varying degrees. The drawdown curves of the water levels in respective observation wells generally were delayed according to orientation, as in the other FLI test (fig. 47b). In contrast to the FL1 test, observation well 27-1308 is oriented in a direction from the FL2 pumped well that is nearly parallel to the valley axis. Its drawdown curve is the least delayed of the six, providing further indication that the major and minor principal directions of the anisotropic transmissivity tensor are approximately down-and crossvalley, respectively. Results of steadystate simulations (discussed earlier) also indicated these directions of the regional anisotropy tensor. At the local scale, however, anisotropy may differ substantially in magnitude and direction. 


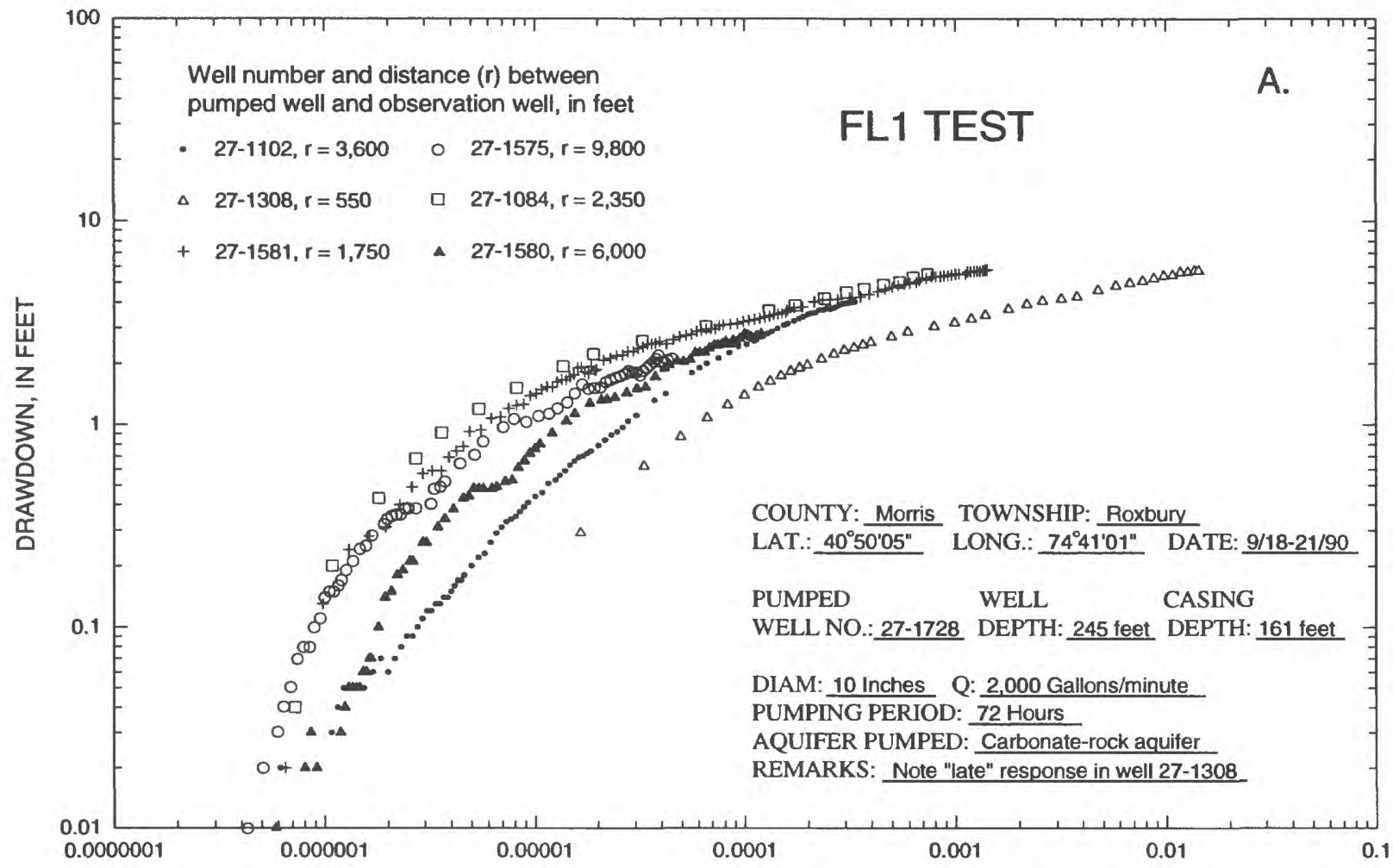

TIME DIVIDED BY DISTANCE SQUARED, IN MINUTE PER FEET SQUARED

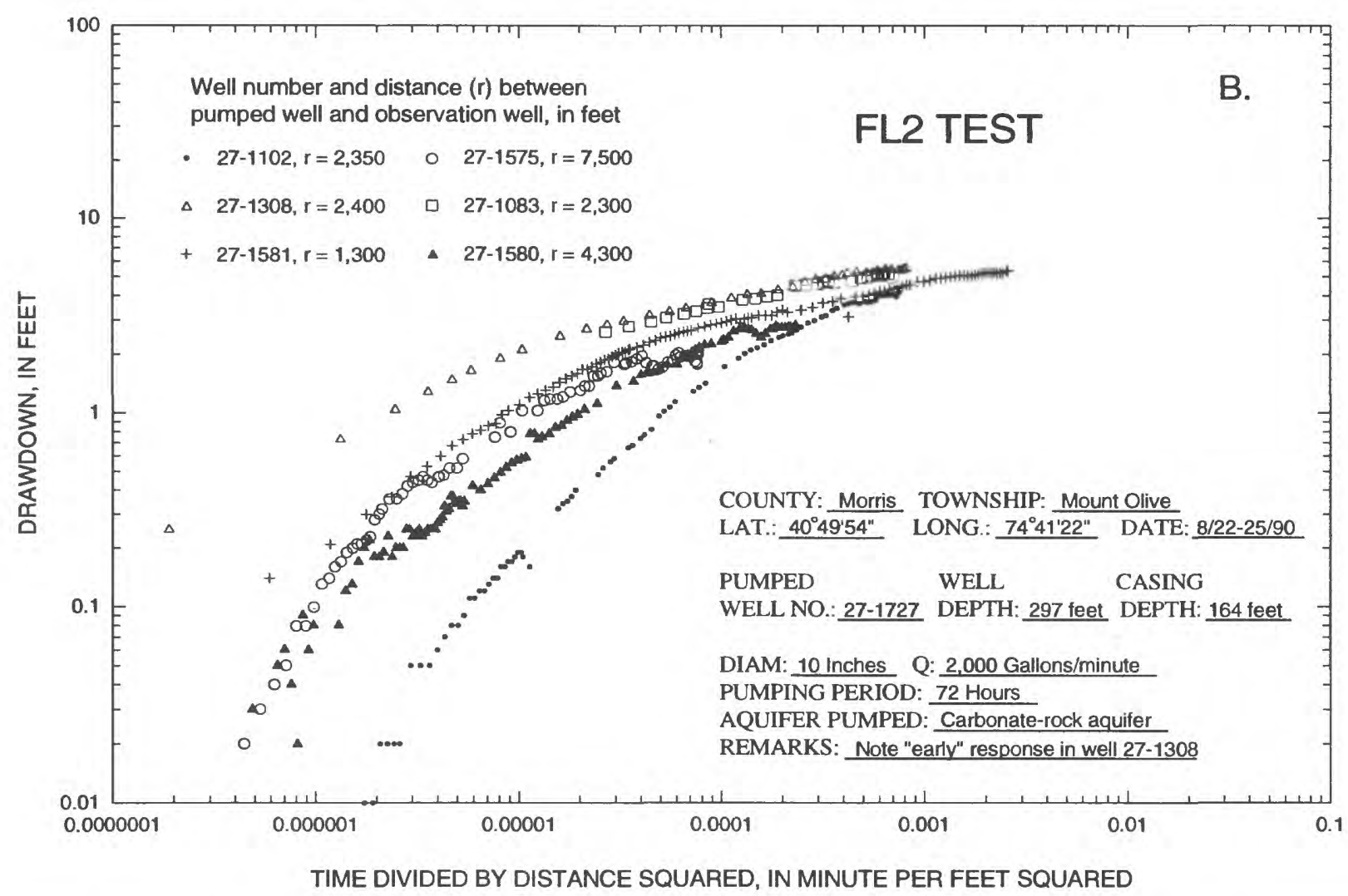

Figure 47. Logrithmic plots of drawdown observed over time in six observation wells open to the carbonaterock aquifer, observed during the Morris County Municipal Utilities Authority (A) FL1 and (B) FL2 aquifer tests at Flanders, New Jersey, September 1990 and August 1990 
The complexity of lateral boundaries, aquifer heterogeneity, and anisotropy required that the test results be analyzed with the ground-water-flow model. This analysis allowed several model concepts to be tested and evaluated. The test was analyzed by means of the transient simulation of draw down resulting from the additional stress with simulated steady-state heads as initial conditions and with other steadystate stresses maintained. A single 3-day stress period was simulated in 50 time steps. Successive time steps were increased by a factor of 1.2 . The resulting simulated time-draw down curves at various locations were compared with observed time- drawdown curves for observation wells corresponding to those locations.

Measured and simulated drawdowns as a function of time agree fairly closely for each of six observation wells, as shown in figure 48 . The overall agreement between the observed and simulated timedrawdown responses is an indication of the accuracy of the model representation of flow-system concepts, including geometry, hydrologic boundaries, distribution of hydraulic properties, and anisotropy in the central part of the aquifer system affected by the test.

On the basis of interpreted head distributions and hydrogeologic-framework data, the carbonaterock aquifer is unconfined in places near the valley walls near Flanders; this concept was incorporated in the aquifer- test simulations. The storage coefficient of an unconfined aquifer is much higher than that of the same aquifer material under confined conditions, and results of repeated simulations of the aquifer tests with various storage-coefficient values indicate the possible effect of this difference on the aquifer response during the tests. Simulated early-time drawdown was controlled to a large extent by the simulated confined storage coefficient. Simulated later-time draw down was controlled largely by the unconfined storage coefficient. Through trial-and-error simulation it was determined that a confined storage coefficient of $2.5 \times 10^{-4}$ and an unconfined storage coefficient of $1.5 \times 10^{-2}$ resulted in the best overall time-drawdown match for the six observation wells.

The areal distribution of measured and model-simulated draw down in the carbonate-rock aquifer at the end of the 72-hour pumping period is shown in figure 49. The drawdown distribution among seven wells indicates an elliptical cone of depression, which is typical in systems characterized by lateral anisotropy. The long axis of the ellipsoid parallels the valley axis, indicating that the direction of the major principal component of hydraulic conductivity also parallels the valley axis. An anisotropy factor of 7.5 resulted in the best match between simulated and observed conditions; this value is considered a reasonable estimate for the regional water-supply analysis presented here. The anistropy of the hydraulic conductivity of the aquifer is highly scale-dependent; the magnitude and orientation of anisotropy may be different at the local scale.

From the results of this analysis, it was determined that a zone of highly permeable carbonate rock extends from the area near the well pumped during the FL1 test downvalley at least as far as Bartley, where the carbonate-rock aquifer is in good hydraulic connection with the South Branch Raritan River. The simulated value of hydraulic conductivity in the major principal component (downvalley) direction in this zone was $864 \mathrm{ft} / \mathrm{d}$, which is reasonable for a highly solution-channeled dolomite. In the crossvalley direction, the simulated value is less by a factor of 7.5 , or $115 \mathrm{ft} / \mathrm{d}$.

Several wells open to the Precambrian rock within $4,500 \mathrm{ft}$ of the pumped well to the south and east did not respond to pumpage during the test, indicating that the permeability of the Precambrian rock probably is low and that it most likely does not contribute much recharge to the carbonate-rock aquifer in this area. Results of model simulations corroborate this concept; when the Precambrian rock was simulated as a head-dependent flux boundary to represent it as a more permeable unit, the simulated drawdown distribution was distorted from the measured distribution. The agreement between the observed and simulated drawdown distributions also supports the concept that the conductivity of the carbonate-rock aquifer is much lower in the areas where it is overlain by the Silurian Green Pond Conglomerate; the effect of this lower conductivity over the short duration of the test, as the simulated and observed drawdown distributions show, is similar to that of a no-flow boundary, causing the effects of pumpage to extend far up the valley along the southern side of the Green Pond Conglomerate, where the carbonate-rock aquifer is more permeable. 

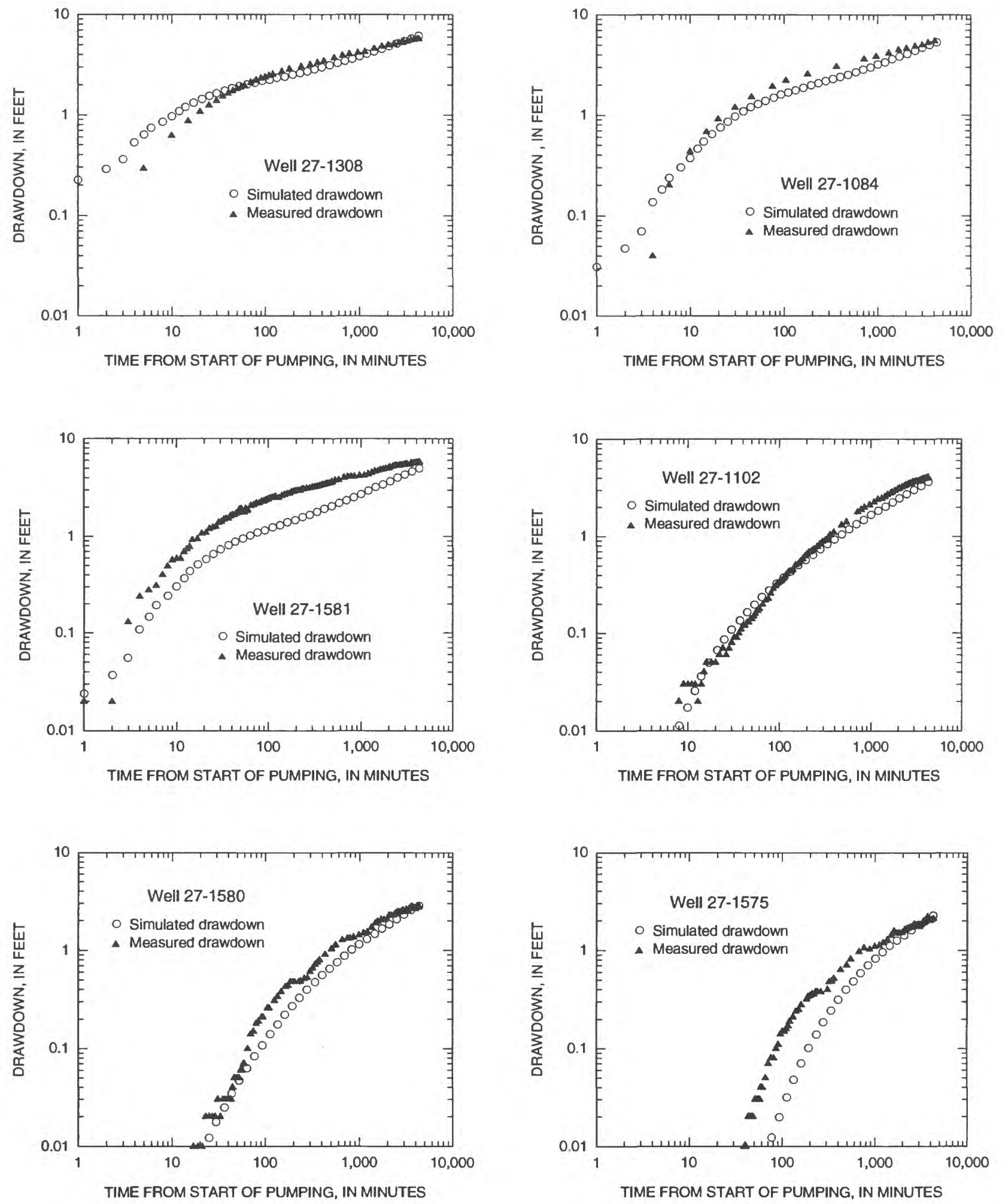

Figure 48. Observed and simulated drawdown over time in six observation wells open to the carbonate-rock aquifer, Morris County Utilities Authority FL1 aquifer test at Flanders, New Jersey, September 1990. 


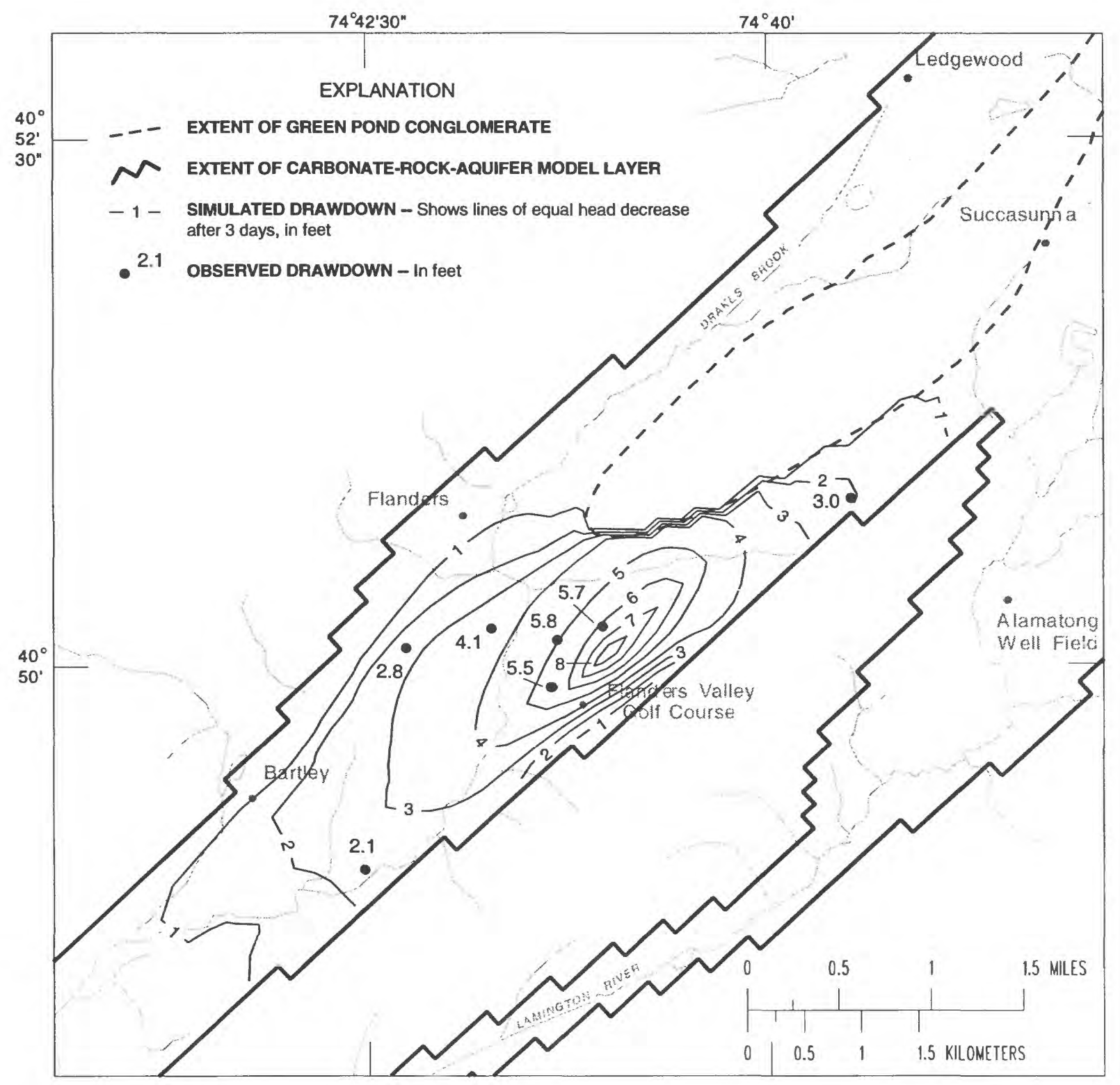

Figure 49. Observed and simulated drawdown in the carbonate-rock aquifer after 3 days of pumping, Morris County Municipal Utilities Authority FL1 aquifer test at Flanders, New Jersey, September 1990. 


\section{Local-scale tests}

Three local-scale tests were conducted to evaluate characteristics of the carbonate-rock aquifer at specific locations.

The local-scale tests of the carbonate-rock aquifer involved the response to stresses measured in fractured and solution-channeled rock over relatively short distances $(<500 \mathrm{ft})$. Over such short distances, ground water in the carbonate-rock aquifer flows predominantly along individual solution channels and other discrete openings, calling into question whether a continuum approach (as defined by Bear and Verruijt, 1987, p. 17-18) is theoretically justified. In each case, however, the response curves matched classic type curves fairly closely, indicating that a continuum approach probably is justified. Tests of the carbonate-rock aquifer can be complicated by many factors, including conduit flow in large solution openings; poorly understood local boundaries; variability in the density, size, orientation, and extent of solution openings; and local-scale anisotropy. These factors were considered in drawing conclusions from the results of these tests.

The Roxbury Water Company 1A test was conducted during January 4-10, 1990, by the Roxbury Water Company, in cooperation with the USGS and the NJGS. Roxbury Water Company well 1-A (27-1733), which is open to the entire thickness of the confined carbonate-rock aquifer, was pumped at a constant rate of $240 \mathrm{gal} / \mathrm{min}$ for a period of 72 hours. Three wells in which water levels were monitored during the test included a 607-ft-deep well (27-1322) open to the carbonate-rock aquifer $90 \mathrm{ft}$ from the pumped well, a 154-ft-deep well (27-1191) open to the lower valley-fill aquifer about 2,800 ft from the pumped well, and a 52-ft-deep well (27-1100) open to the upper valley-fill aquifer $40 \mathrm{ft}$ from the pumped well. The response of water levels in well 27-1322 in the carbonate-rock aquifer was analyzed by using the method of Cooper and Jacob (1946) to estimate the horizontal hydraulic conductivity and storage coefficient of the carbonate-rock aquifer. The test site is located in an area where the carbonate-rock aquifer is separated from the lower valley-fill aquifer by about $70 \mathrm{ft}$ of clay residuum.

Drawdown in the deep observation well in the carbonate-rock aquifer as a function of time is shown in figure 50. Water levels in the well did not change appreciably during the 24-hour period prior to the start of the test; therefore, drawdown values were not adjusted for any pretest trend. The plot shows a steady slope between 300 and 600 minutes. After 600 minutes, the slope changes a number of times, possibly as a result of the cyclic pumping of other nearby pumped wells, or of the presence of a recharge boundary, such as areas where leakage from the lower valley-fill aquifer is substantial because the confining clay residuum is absent. Because the pumping rate remained at $240 \mathrm{gal} / \mathrm{min}$ throughout the test, the changes in slope were not caused by changes in the pumping rate.

Graphical analysis of the steady-slope portion of the time-drawdown curve indicates a transmissivity of about $2,114 \mathrm{ft}^{2} / \mathrm{d}$ and a storage coefficient of about 0.01 ; however, the test results were affected by complex recharge and discharge boundaries, which affect the accuracy of these estimates. Recharge boundaries include large, discrete solution openings in the carbonate rocks and areas where leakage from the overlying lower valley-fill aquifer is substantial. A dominant effect of these boundaries would be the overestimation of the storage coefficient. Discharge boundaries include the irregular contact between the carbonate- rock aquifer and the bounding, low-permeability, noncarbonate rock, and aquifer zones with significant reductions in the size and density of solution openings. The dominant effect of these boundaries would be the underestimation of transmissivity. The values determined through this analysis can be considered lower and upper bounding values, respectively, for the actual transmissivity and storage coefficient of the aquifer at the site.

Water levels in the observation well in the lower valley-fill aquifer declined about $1 \mathrm{ft}$ during the test, indicating a good hydraulic connection between the carbonate-rock and lower valley-fill aquifers. The water level in the shallow well in the upper valley-fill aquifer did not respond to pumping, indicating that the test did not affect the altitude of the water table at the site. 


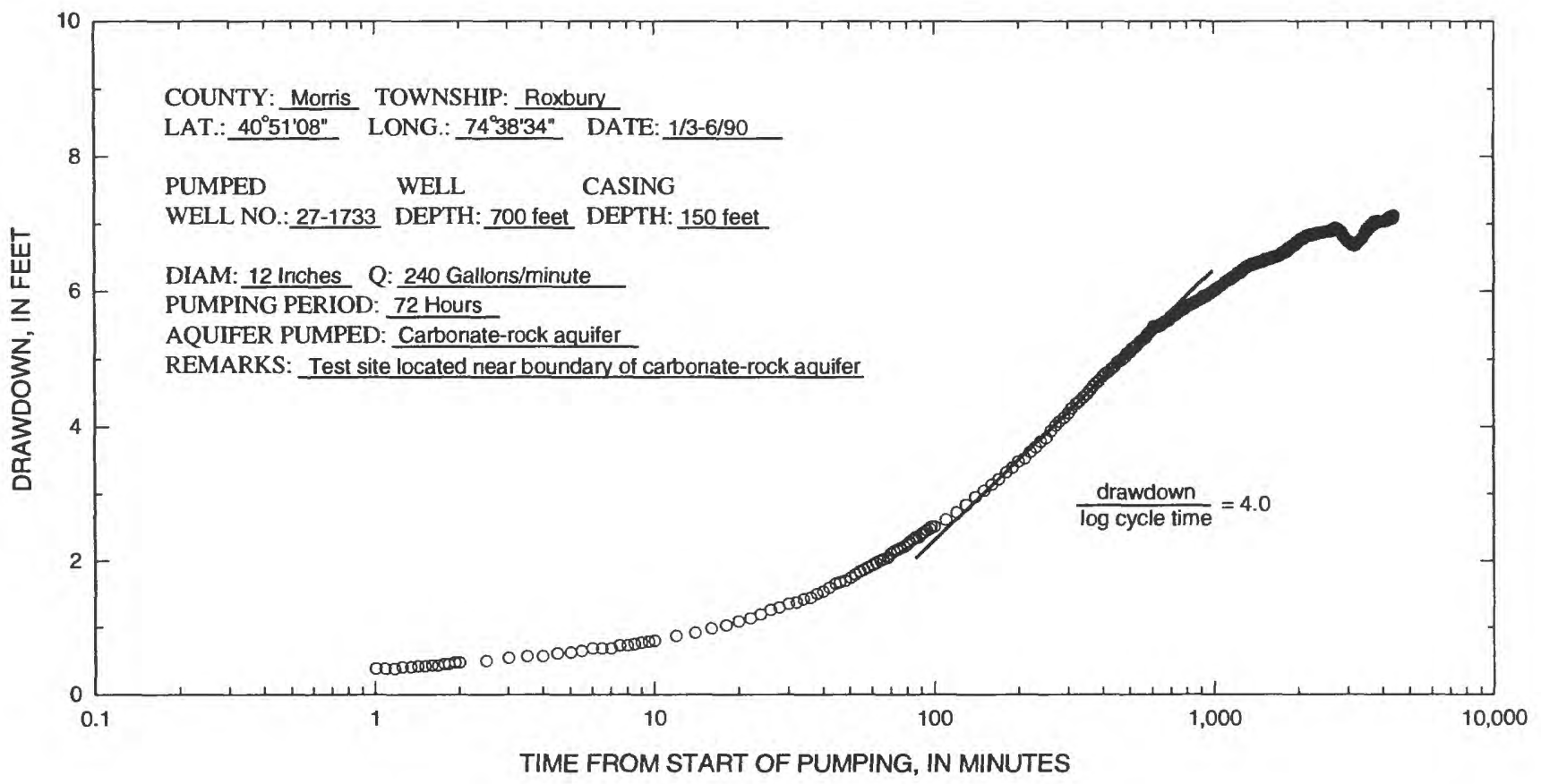

Figure 50. Semilogarithmic plot of drawdown over time in observation well 27-1322 during the Roxbury Water Company 1-A aquifer test at Succasunna, New Jersey, January 1990.

The USGS Black River 4 test was conducted from April 30, 1990, to May 1, 1990, at a site where the carbonate-rock aquifer is bounded by non-carbonate rock in a narrow valley and is overlain by about $150 \mathrm{ft}$ of glacial sediment. Well 27-1126, which is open to the carbonate-rock aquifer, was pumped at a rate of $100 \mathrm{gal} / \mathrm{min}$ for 17 hours.

The observed recovery of the pumped well was evaluated by using the method of Cooper and Jacob (1946) to estimate the transmissivity of the carbonate-rock aquifer at the site. Several nearby observation wells open to the overlying confining unit sediments and the bounding igneous rock were monitored during the pumping and recovery cycles in order to evaluate qualitatively the hydraulic connection between the carbonate-rock aquifer and these units. The recovery of the pumped well is shown in figure 51. Graphical analysis of the data indicates a transmissivity of $1,100 \mathrm{ft}^{2} / \mathrm{d}$. The water-level recovery was affected by the bounding low-permeability rock on both sides of the narrow valley, which probably functioned as discharge boundaries; however, these effects probably woud have been evident in the very early time following the start of recovery, before recovery measurements were made. Therefore, this value of tansmissivity is probably lower than the actual value and can be considered a lower bounding value.

The water level in well 27-1164, a shallow observation well in the overlying confining unit sediments $20 \mathrm{ft}$ from the pumped well, was lowered promptly by pumping, indicating a vertical connection between the carbonate-rock aquifer and these sediments. After 17 hours of pumping, the water level in this well had fallen, $2.9 \mathrm{ft}$. This vertical connection is consistent with the concept that carbonate-rock aquifer is recharged through these sediments in this area. Water levels in the more distant observation wells (27-1557, 27-1559) tapping the bounding crystalline rocks fluctuated less than $0.2 \mathrm{ft}$ throughout the course of the test supporting the concept that the noncarbonate rock has low permeabiity and does not contribute significant recharge to the carbonate-rock aquifer.

A test of the specific capacity of the NJGS Drew University well (27-1303) was conducted from April 16 to 18,1990 , at a site where the carbonate-rock aquifer is overlain by about $70 \mathrm{ft}$ of glacial sediment and is bounded by low-permeability Precambrian rock at the valley walls about 2,000 ft to the northwest and southeast. The well, which is open to the carbonate-rock aquifer, was pumped at a rate of $100 \mathrm{gal} / \mathrm{min}$ for 11.5 hours. At the end of 


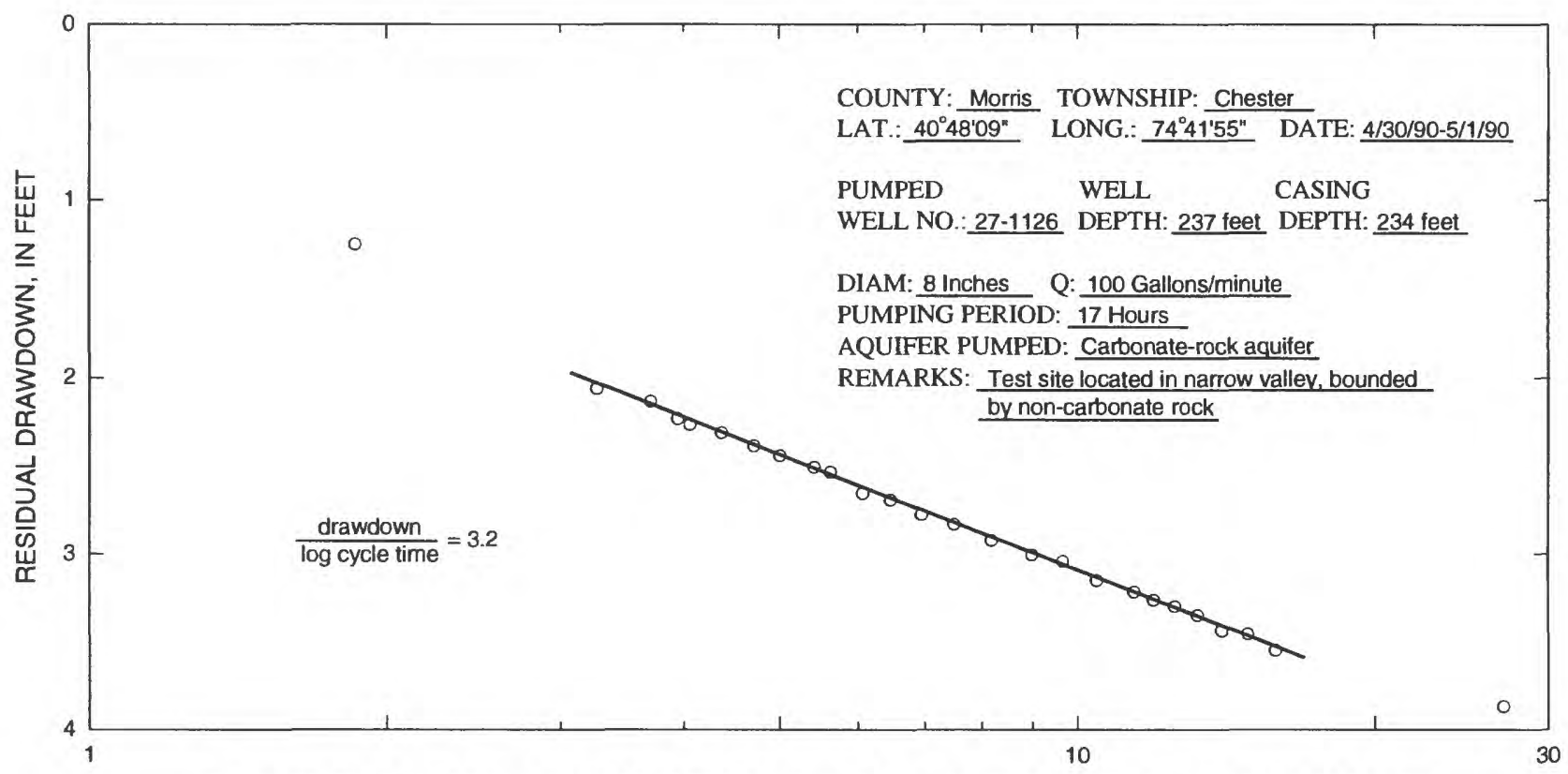

ELAPSED TIME SINCE PUMPING STARTED DIVIDED BY ELAPSED TIME SINCE PUMPING STOPPED

Figure 51. Semilogarithmic plot of recovery over time in well 27-1126 during the USGS Black River 4 aquifer test near Chester, New Jersey, April 1990.

the test, drawdown in the well was only $1 \mathrm{ft}$, so the specific capacity was 100 (gal/d)/ft. Although the primary purpose of the test was to determine the specific capacity of the pumped well, the water level in a nearby well 27-1119) also was measured. Ths well is $2,400 \mathrm{ft}$ from the pumped well and also is open to he carbonate-rock aquifer. The few available drawdown data were analyzed by using the Theis analysis (Theis, 1935) to obtain rough estimates of the transmissivity and storage coefficient of the carbonate-rock aquifer. Analysis of the limited drawdown data indicates a transmissivity of about $9,000 \mathrm{ft}^{2} / \mathrm{d}$ and a storage coefficient of $8 \times 10^{-4}$. Several hydrologic boundaries probably affected the water-level response in the observation well, including the bounding low-permeability noncarbonate rock and the South Branch Raritan River, which is in good hydraulic connection with the carbonate-rock aquifer near the test site. Furthermore, the carbonate-rock aquifer is confined at the pumped-well location, but it is unconfined in other, nearby areas. Assessment of the accuracy of the estimates of the hydraulic properties of the aquifer is difficult as a result of these factors and of aquifer heterogeneity; therefore they are considered only very crude approximations.

\section{Model Sensitivity Analysis}

The process of calibrating the steady-state ground-water flowmodel resulted in estimates of aquifersystem characteristics such as hydraulic conductivity, vertical leakance, streambed conductance, and recharge rates. The extent to which system characteristics control flow within the system was determined through an evaluation of the sensitivity of model outputs (hydraulic heads and streamflow gains and losses) to variations in input parameters. Steady-state model-input parameters were varied over reasonable ranges throughout the calibration process; the effects of these variations on model outputs are described below. The sensitivity of simulated transient drawdown distriutions to anisotropy of the horizontal hydraulic conductivity of the carbonate-rock aquifer also is described.

The sensitivity of the model to variations in the horizontal hydraulic conductivity of each of the three aquifer units was determined. The upper valley-fill aquifer is in good hydraulic connection with a relatively dense network of surface-water bodies, including rivers, lakes, and ponds. These surface-water bodies control the altitude of the water table to such an extent that simulated water levels over most of the upper valley-fill aquifer changed little when the hydraulic conductivity was increased or decreased by about an order of magnitude. The model is more sensitive to this parameter at Picatinny Arsenal and northeast of Ledgewood, where calibrated values of hydraulic conductivity are lower than in most other areas. 
The model is highly sensitive to variations in the horizontal hydraulic conductivities of the lower valley-fill and carbonate-rock aquifers over a similar range, particularly near cones of depression and in the Flanders area. The sensitivities of calibrated values of hydraulic conductivity of the lower valley-fill and carbonate-rock aquifers north of Flanders are highly correlated as a result of the good hydraulic connection between the two units over large areas. In testing the sensitivity of the two parameters, it was observed that a variation in one parameter was observed to affect hydraulic head in both aquifer units.

The sensitivities of steady-state head distributions and transient drawdown distributions to variations in lateral anisotropy of the horizontal hydraulic conductivity of the carbonate-rock aquifer were tested. The effect of decreasing the anisotropy ratio was simulated by increasing values of the crossvalley hydraulic conductivity by a factor of 2 without changing downvalley hydraulic-conductivity values. In the southern part of the study area, steady-state heads distant from rivers declined and head gradients in the crossvalley direction decreased. In the northern part, where the carbonate-rock aquifer is confined, heads also declined. The sensitivity of transient drawdown distribution to anisotropy in the Flanders area in the simulation of the MCMUA FL1 aquifer test was tested by increasing hydraulic conductivity in the crossvalley (column) direction by 50 percent. The effect of the resulting lower anisotropy ratio (5:1) was a lower 3-day drawdown and a more circular distribution of drawdown than that shown in figure 49. A higher ratio (lower crossvalley hydraulic conductivity) resulted in higher 3-day drawdown and a more elliptical drawdown distribution.

The vertical hydraulic conductivity of the upper confining unit controls the rate of vertical leakage between the upper valley-fill aquifer and underlying aquifers. As a result, the hydraulic head in the underlying aquifers increased substantially when this parameter was increased by an order of magnitude.

Ground-water discharge to streams from the upper valley-fill aquifer also is sensitive to this parameter, although the head in the upper valley-fill aquifer is not. The model is not as sensitive to the vertical hydraulic conductivity of the lower confining unit between the lower valley-fill aquifer and the carbonate-rock aquifer to the north of Flanders, because the vertical leakance between the two aquifers is high over large areas where the lower confining unit is absent; rates of vertical flow were similar when the vertical hydraulic conductivity of the confining unit was increased or decreased by an order of magnitude. Near Flanders, the lower confining unit is more continuous than to the north of Flanders; therefore, heads in the lower valley-fill and carbonate-rock aquifers in this area are sensitive to the vertical hydraulic conductivity of the confining unit over a range of 2 orders of magnitude. The distribution of ground-water discharge to Drakes Brook also is affected by the extent of the lower confining unit near Flanders. If the lower confining unit is continuous southward to the confluence of Drakes Brook and the South Branch Raritan River, the flow path to Drakes Brook would be restricted, and less ground water would discharge to Drakes Brook than if the confining unit is not continuous to this river confluence; correspondingly more ground water would discharge to the South Branch Raritan River to the south of Bartley.

Streambed conductance affects the distribution of base flow and heads in unconfined aquifers, but these model outputs are less sensitive to this parameter than they are to aquifer hydraulic conductivity. The sensitivities of streambed conductance and aquifer hydraulic conductivity are correlated because together they define the conductance of the entire flow path from point of recharge to the point of discharge to the river. Leakage from tributary streams to unconfined aquifers is sensitive to streambed conductance and also to other model parameters that determine aquifer head beneath tributary reaches.

Heads in the lower valley-fill aquifer and the carbonate-rock aquifer were sensitive to a 30-percent increase in recharge, but heads in the upper valley-fill aquifer were less sensitive to this increase because of the nature of surface-water boundaries discussed earlier. Base flow increased proportionally with recharge. 


\section{Simulation of Predevelooment Conditions}

Few data are available to define predevelopment conditions in the aquifer system accurately. Therefore, little is known about actual water levels and the water budget before the development of the aquifer system for water supply. Predevelopment conditions were estimated through simulation. Average predevelopment conditions were simulated by using the same boundary conditions and aquifer and confining-unit parameters that were used to simulate recent steady conditions, except that all pumping stresses were omitted. The results of this simulation were compared with those of the simulation of recent steady conditions in order to estimate changes in average water levels and the water budget that have resulted from recent withdrawals. The results of this simulation also were evaluated to determine whether the estimated changes are reasonable in comparison with the available historical data, thus providing an additional check on the model representation of the flow system.

\section{Water Levels}

Figures 52, 53, and 54 show the magnitude and distribution of estimated changes in average water levels in the three aquifers from predevelopment conditions to recent conditions. Estimated water-level declines in the upper valley-fill aquifer are less than $1 \mathrm{ft}$ in most areas and up to $10 \mathrm{ft}$ near pumped wells. These estimates are considered reasonable. The excavation of sand and gravel pits over several decades in the Kenvil area may have lowered the local water table and increased the base flow of streams draining the pits. These effects have not been documented and were not simulated, however. Estimated water-level declines in the lower valley-fill aquifer range from $<1 \mathrm{ft}$ in areas distant from pumped wells to $35 \mathrm{ft}$ near the Alamatong well field; estimated declines near the supply wells at Kenvil are about $24 \mathrm{ft}$. Estimated water-level declines in the carbonate- rock aquifer range from zero in the southern part of the study area to $35 \mathrm{ft}$ near the Alamatong well field. Simulated declines of between 3 to $6 \mathrm{ft}$ resulting primarily from pumpage at the Alamatong well field extend beyond the location of well 27-1123 (pl. 1a), where water-level fluctuations in response to pumping cycles from Alamatong well 5 (27-1090) were observed (fig. 44). This observation indicates that the estimated extent of the declines is plausible.

\section{Water Budget}

Simulated recent and predevelopment water budgets also were compared to estimate the changes that have occurred in the budget as a result of recent withdrawals. Figure 55 shows the aquifer-system water budget under predevelopment and recent conditions. These budgets show that the changes that are attributable to withdrawals are (1) a decrease in discharge from aquifers to streams, (2) a net increase in flow between aquifers, and (3) a slight increase in leakage from streams to aquifers. Because the decrease in ground-water discharge to streams has been diffused over many stream reaches and may be masked by historical wastewater return flows that have accompanied withdrawals, changes in base flow are not apparent from interpretations of field data.

\section{Simulation and Hydrologic Effects of Additional Ground-Water Withdrawals}

The hydrologic effects of additional ground-water withdrawals from the carbonate-rock aquifer were evaluated by simulating pumpage from a hypothetical well field in the headwaters of the South Branch Raritan River (fig. 56), where additional withdrawals are likely in the future (J.S. Malleck, New Jersey Department of Environmental Protection and Energy, written commun., 1991). In scenario A, simulated additional pumpage from this well field of $5.7 \mathrm{Mgal} / \mathrm{d}$ is distributed among three wells (table 10). This additional pumpage represents a 121-percent increase over recent, average pumpage from the entire aquifer system, and is comparable to the demand projected for the 50-year period 1990-2040 for the three primary public suppliers that withdrew water from the aquifer system (J.S. Malleck, New Jersey Department of Environmental Protection and Energy, written commun., 1991). In scenario B, the additional pumpage is $4.8 \mathrm{Mgal} / \mathrm{d}$ distributed among the three wells, and simulated pumpage from each of the five 


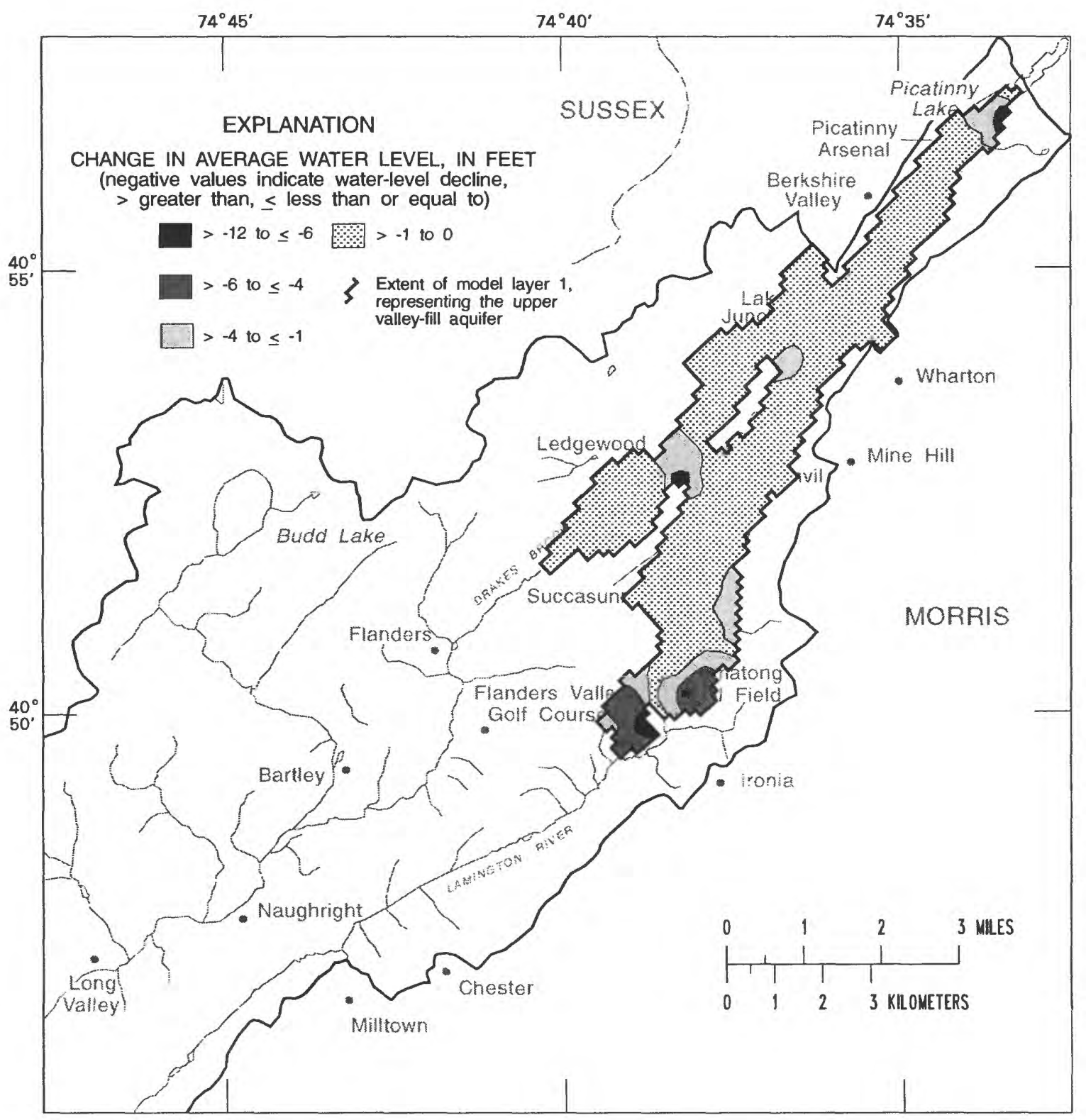

Figure 52. Simulated change in average water levels in the upper valley-fill aquifer from predevelopment conditions that resulted from recent ground-water withdrawals. 

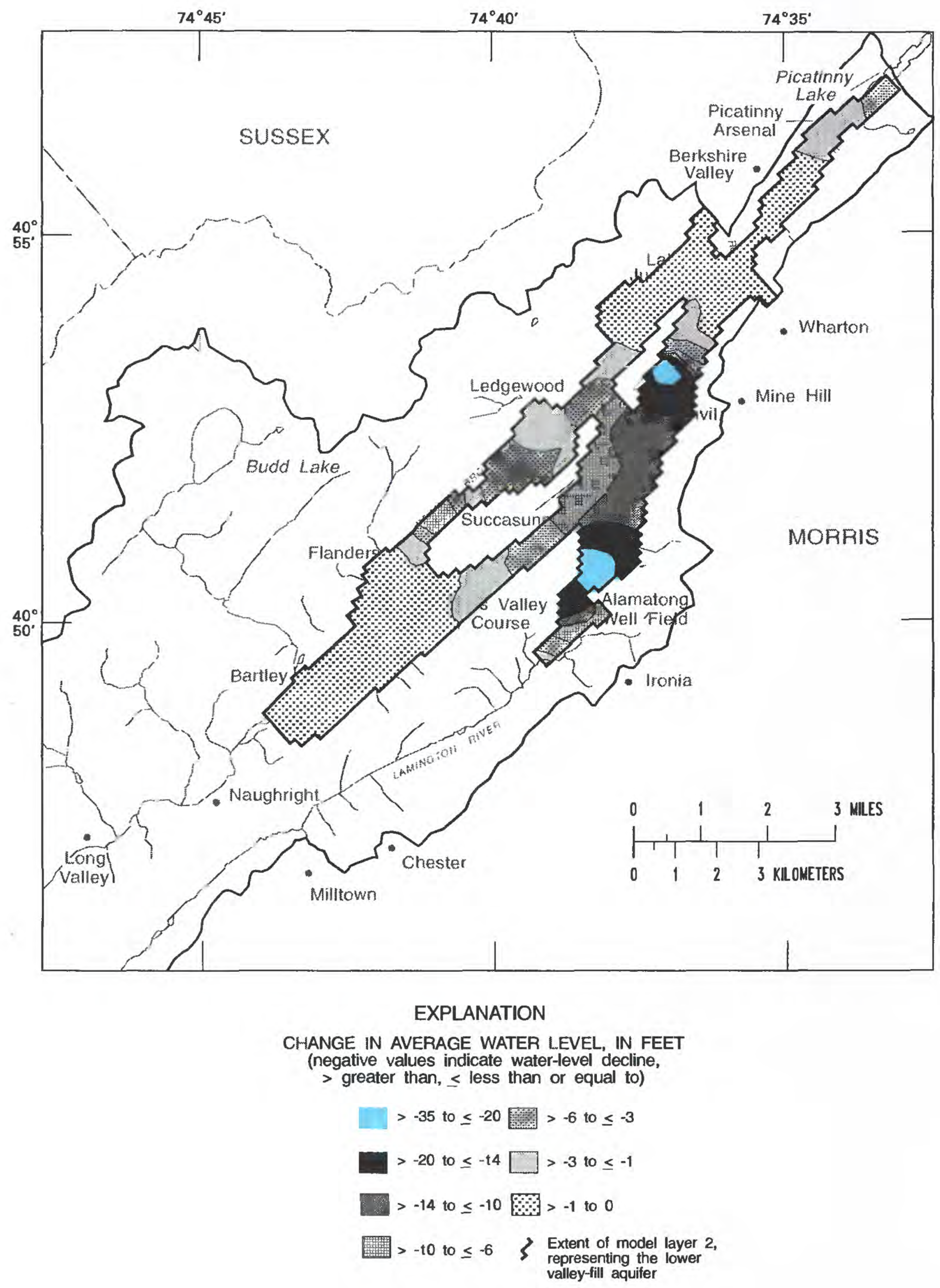

Figure 53. Simulated change in average water levels in the lower valley-fill aquifer from predevelopment conditions that resulted from recent ground-water withdrawals. 


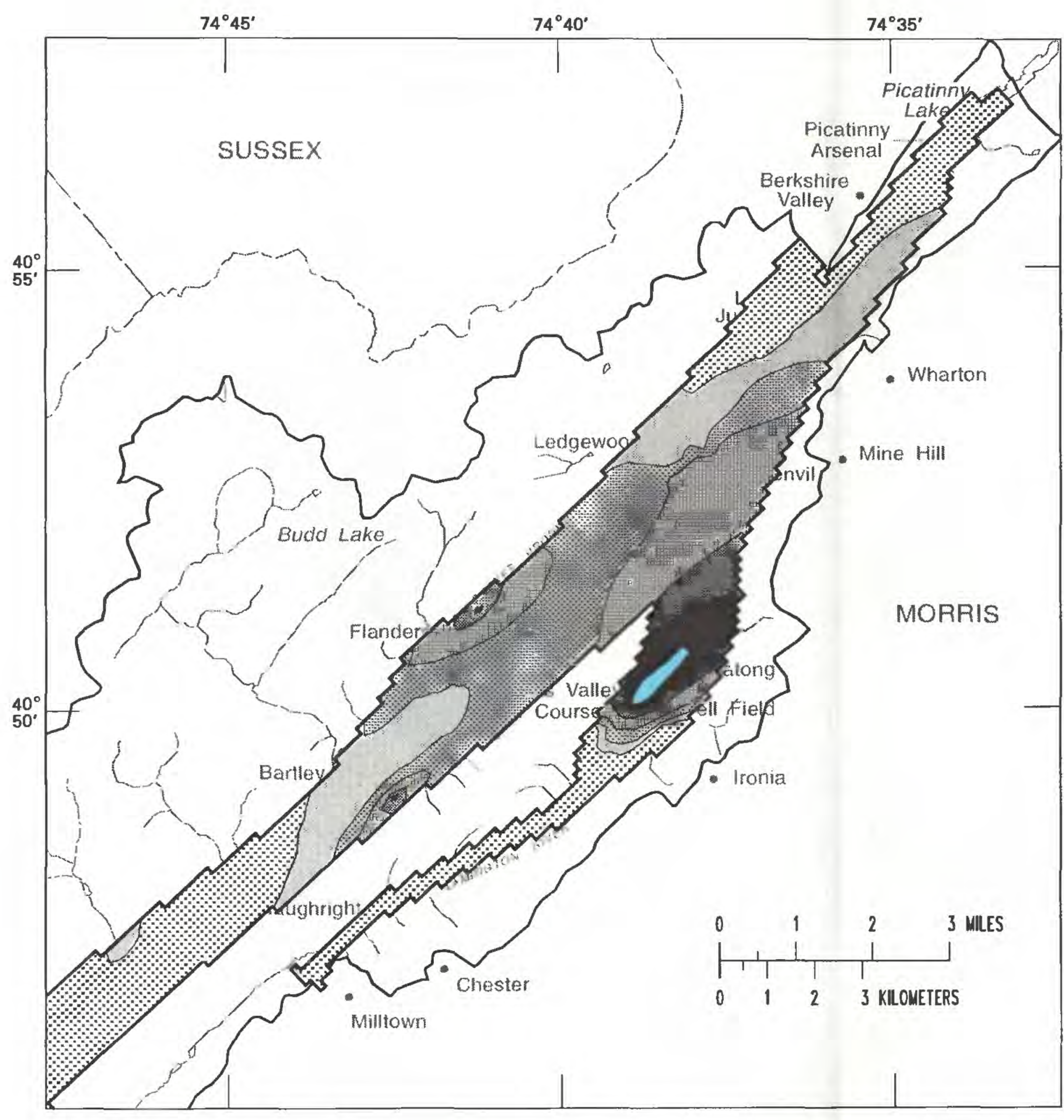

\section{EXPLANATION}

CHANGE IN AVERAGE WATER LEVEL, IN FEET

(negative values indicate water-level decline,

$>$ greater than, < less than or equal to)

$$
\begin{aligned}
& >-35 \text { to } \leq-20 \text { 艮 }>-6 \text { to } \leq-3 \\
& >-20 \text { to } \leq-14>-3 \text { to } \leq-1 \\
& >-14 \text { to } \leq-10>-1 \text { to } 0 \\
& >-10 \text { to } \leq-6 \quad 3 \begin{array}{l}
\text { Extent of model layer } 3, \\
\text { representing the carbonate } \\
\text { rock aquifer }
\end{array}
\end{aligned}
$$

Figure 54. Simulated change in average water levels in the carbonate-rock aquifer from predevelopment conditions that resulted from recent ground-water withdrawals. 
FLOW, IN CUBIC FEET PER SECOND

OUTFLOW

INFLOW

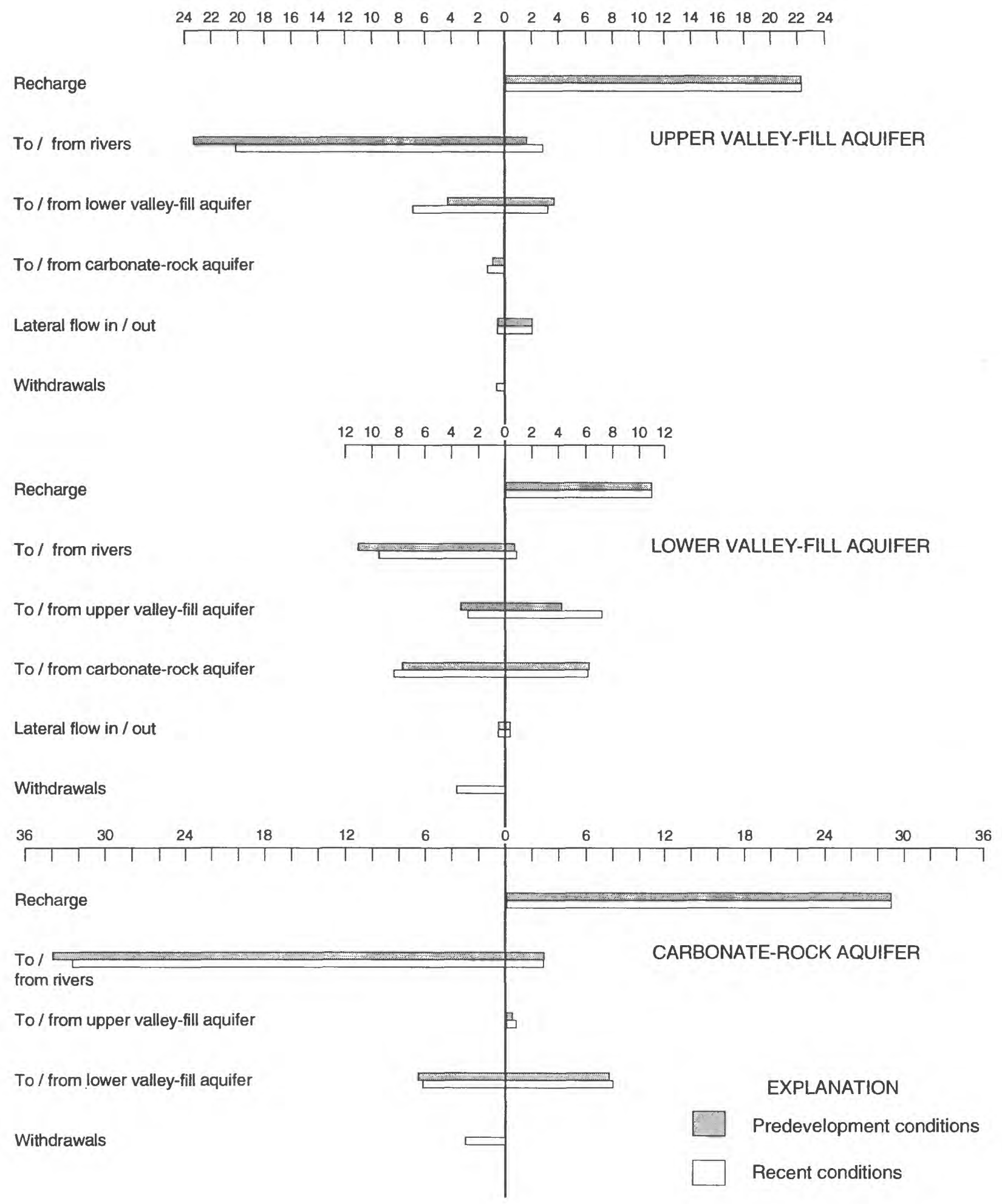

Figure 55. Simulated water budgets for the New Jersey Highlands aquifer system near Long Valley under predevelopment and recent average conditions. 


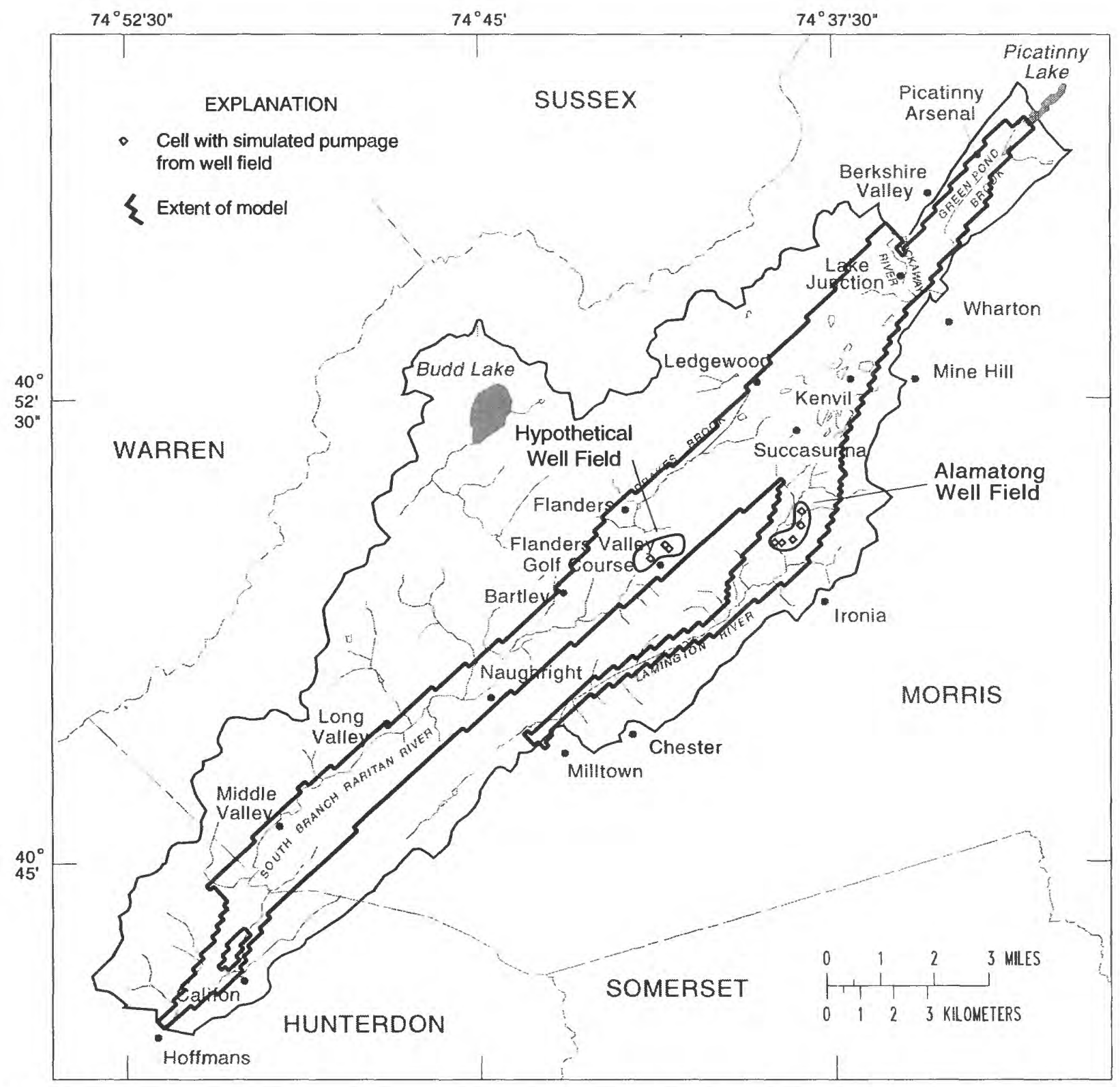

Figure 56. Locations of the Morris County Municipal Utilities Authority Alamatong well field; the hypothetical well field at Flanders, New Jersey; and the model cells used to simulate withdrawals from the well fields. 
Table 10. Summary of simulated alternative water-supply scenarios

\begin{tabular}{|c|c|c|c|c|}
\hline \multirow{2}{*}{$\begin{array}{c}\text { Simulated well(s) } \\
\text { (New Jersey well } \\
\text { number) }\end{array}$} & \multirow{2}{*}{$\begin{array}{l}\text { Model node } \\
\text { (layer, row, } \\
\text { column) }\end{array}$} & \multicolumn{3}{|c|}{ Simulated pumpage, in million gallons per day } \\
\hline & & $\begin{array}{l}\text { Present } \\
\text { conditions }\end{array}$ & Scenario A & Scenario B \\
\hline Hypothetical & $(3,18,136)$ & 0 & 2.35 & 1.9 \\
\hline Hypothetical & $(3,19,140)$ & 0 & 2.35 & 1.9 \\
\hline Hypothetical & $(3,18,140)$ & $\mathbf{0}$ & 1.0 & 1.0 \\
\hline $\begin{array}{l}\text { Alamatong } \\
\text { well field \#1 } \\
(27-1314)\end{array}$ & $(2,33,157)$ & .10 & unchanged & .04 \\
\hline $\begin{array}{l}\text { Alamatong } \\
\text { well field \#2 } \\
(27-1315)\end{array}$ & $(2,34,159)$ & .06 & unchanged & .02 \\
\hline $\begin{array}{l}\text { Alamatong } \\
\text { well field \#3 } \\
(27-1323)\end{array}$ & $(2,33,162)$ & .006 & unchanged & .002 \\
\hline $\begin{array}{l}\text { Alamatong } \\
\text { well field \#4 } \\
(27-1324)\end{array}$ & $(2,31,164)$ & 1.1 & unchanged & .4 \\
\hline $\begin{array}{l}\text { Alamatong } \\
\text { well field \#5 } \\
(27-1090)\end{array}$ & $(3,32,156)$ & .8 & unchanged & .3 \\
\hline $\begin{array}{l}\text { All other } \\
\text { wells }\end{array}$ & Various & 2.6 & unchanged & unchanged \\
\hline Total pumpage & & 4.7 & 10.4 & 8.2 \\
\hline $\begin{array}{l}\text { Net increase } \\
\text { from present }\end{array}$ & & not applicable & 5.7 & 3.5 \\
\hline
\end{tabular}


production wells at the Alamatong well field is decreased by 62 percent (from a total of 2.1 to $0.8 \mathrm{Mgal} / \mathrm{d}$ ) for a simulated net increase in pumpage of $3.5 \mathrm{Mgal} / \mathrm{d}$. Scenario B represents a plausible shorter term strategy that includes shifting pumping stresses into an area where recent ground-water withdrawals have been low. Under this scenario, the 3.5-Mgal/d net increase in total pumpage represents a 74-percent increase above recent average pumpage. Results of the steady-state simulations of these two groundwater- development strategies were compared with results of the steady-state simulation of recent steady conditions to estimate the long-term effects on average water levels, base flow, and flow between aquifers. Although simulation of the transient effects of drought and seasonally variable pumpage and recharge rates are beyond the scope of this report, the magnitude of simulated average base-flow depletion was compared with historical low flows of streams in order to identify streams likely to be adversely affected by additional ground-water withdrawals during seasonal low flows and droughts.

Initial conditions used in these predictive simulations were the same as those used in the simulation of recent steady conditions.

Because the ultimate fate of the additional water pumped under scenarios A and B is uncertain, it was assumed that this water would be used consumptively (removed from the study area). If some of the additional ground water withdrawn is returned to the surface-water system as treated wastewater, then the effects of the withdrawals on rates of streamflow would be mitigated to some degree. If some of the increased pumpage is returned through land disposal of wastewater, the changes in water levels and base flow also would be different from those predicted. The simulated effects of the additional ground-water withdrawals specified for scenarios A and B on water levels, base flow, and the water budget are described below.

\section{Water levels}

Simulated changes in average water levels in the carbonate-rock aquifer under scenarios $\mathrm{A}$ and B are shown in figures 57 and 58, respectively. Under scenario A, average water levels in the carbonaterock aquifer would decline up to $28 \mathrm{ft}$ at the hypothetical well field; declines would exceed $1 \mathrm{ft}$ in an area extending about $6 \mathrm{mi}$ to the northeast and about $3 \mathrm{mi}$ to the southwest. Water-level declines northeast of the hypothetical well field would induce increased leakage from the overlying valley-fill aquifers; the amount of this leakage would control the magnitude and extent of water-level declines in this area. Waterlevel declines southwest of the well field would be limited by the good hydraulic connection between the carbonate-rock aquifer and the South Branch Raritan River southwest of Bartley.

Under scenario B, the average water-level decline at the hypothetical well field would be about 24 $\mathrm{ft}$. The area in which declines would exceed $1 \mathrm{ft}$ would be slightly smaller than that under scenario A-about $5.5 \mathrm{mi}$ from the hypothetical well field to the northeast and about $3 \mathrm{mi}$ (the same as in scenario A) to the southwest. Water levels over most of the Lamington River Basin would rise--about $10 \mathrm{ft}$ near Alamatong wells 4 and 5--in response to the decrease in pumpage from wells at the Alamatong well field.

The magnitudes of predicted water-level changes were compared with the reported pumping levels in six public supply wells that tap the carbonate- rock aquifer in the simulated area of influence. This comparison allows a limited assessment of the degree to which pumpage from the hypothetical well field would affect the operation of those wells. Table 11 lists reported recent pumping water levels, predicted average water-level changes at the locations of the six wells, and predicted pumping water levels under new (hypothetical) pumping conditions assuming superposition of the predicted regional declines. Depths of pump intakes were available for only two of the six wells--the Roxbury Water Company well 1A (27-1733), at $300 \mathrm{ft}$ below land surface, and the Mount Olive Township Water Department well 3 (27-1093), at $130 \mathrm{ft}$ below land surface. Predicted water levels under new pumping conditions in both wells do not approach the depths of the intakes, under either scenario A or scenario B. 


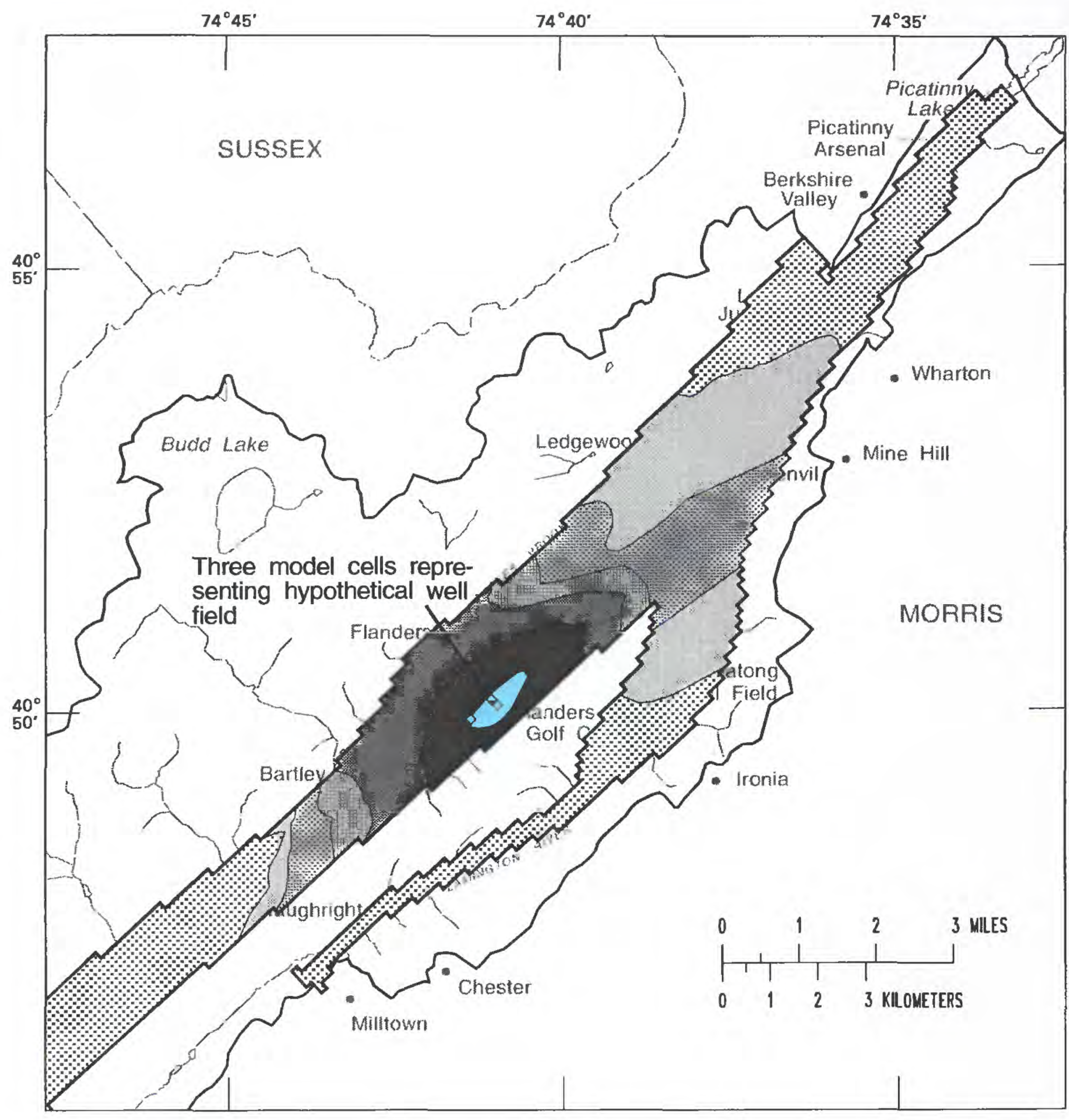

\section{EXPLANATION}

CHANGE IN AVERAGE WATER LEVEL, IN FEET

(negative values indicate water-level decline,

$>$ greater than, $\leq$ less than or equal to)

$$
\begin{aligned}
& >-28 \text { to } \leq-24 \text { 政 }>-8 \text { to } \leq-4 \\
& >-24 \text { to } \leq-18 \square>-4 \text { to } \leq-1 \\
& >-18 \text { to } \leq-12 \text { to } \leq 0 \\
& >-12 \text { to } \leq-8 \quad \text { ? } \begin{array}{l}
\text { Extent of model layer } 3, \\
\text { representing the carbonate } \\
\text { rock aquifer }
\end{array}
\end{aligned}
$$

Figure 57. Simulated change in average water levels in the carbonate-rock aquifer resulting from an additional withdrawal of 5.7 million gallons per day from a hypothetical well field tapping the carbonaterock aquifer. 


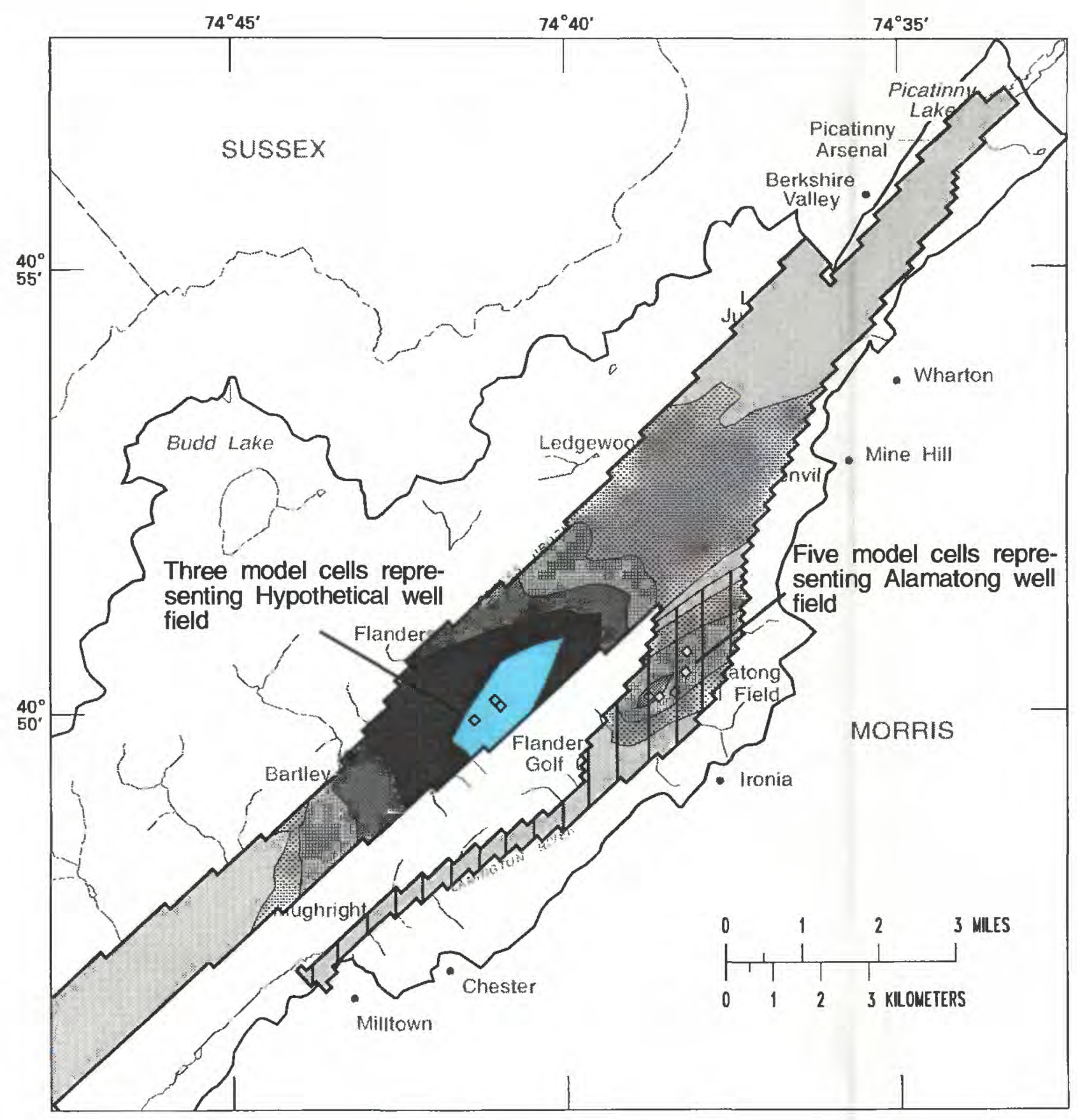

\section{EXPLANATION}

CHANGE IN AVERAGE WATER LEVEL, IN FEET (Positive values indicate water level rise in response

to decreased pumpage from Alamatong well field. Negative values indicate water-level decline, $>$ greater than, < less than or equal to)

$>-24$ to $\leq-18$ 共 $>-4$ to $\leq-1$ 眐 $>3$ to $\leq 6$

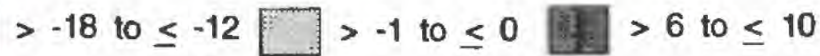

$>-12$ to $\leq-8 \square \square>0$ to $\leq 1<$ Extent of model layer 3 ,

$>-8$ to $\leq-4$ 凋图 $>1$ to $\leq 3$ representing the carbonate rock aquifer

Figure 58. Simulated change in average water levels in the carbonate-rock aquifer resulting from an additional withdrawal of 4.8 million gallons per day from a hypothetical well field tapping the carbonaterock aquifer and a decrease in withdrawals of 1.3 million gallons per day from the Alamatong well field. 


\begin{tabular}{|c|c|c|c|c|c|c|}
\hline \multirow[b]{2}{*}{$\begin{array}{c}\text { New } \\
\text { Jersey } \\
\text { well } \\
\text { number }\end{array}$} & \multirow[b]{2}{*}{$\begin{array}{l}\text { Public supply well owner } \\
\text { and local identifier }\end{array}$} & \multirow[b]{2}{*}{$\begin{array}{c}\text { Reported } \\
\text { pumping } \\
\text { water } \\
\text { level } \\
\text { (feet below } \\
\text { land surface) }\end{array}$} & \multicolumn{2}{|c|}{ Scenario A } & \multicolumn{2}{|c|}{ Scenario B } \\
\hline & & & $\begin{array}{c}\text { Change in } \\
\text { head }^{1} \\
\text { feet }\end{array}$ & $\begin{array}{c}\text { Pumping } \\
\text { water level } \\
\text { (feet below } \\
\text { land surface) }\end{array}$ & $\begin{array}{l}\text { Change } \\
\text { in } \\
\text { head }^{1} \\
\text { (feet) }\end{array}$ & $\begin{array}{l}\text { Pumping } \\
\text { water } \\
\text { level } \\
\text { (feet } \\
\text { below land } \\
\text { surface) }\end{array}$ \\
\hline $27-1090$ & MCMUA 5 & 135 & -1 & 136 & $2>+10$ & $2<125$ \\
\hline $27-1733$ & Roxbury Water Company 1A & 235 & -5 & 240 & $<1$ & 235 \\
\hline $27-1173$ & Roxbury Water Company 7 & 65 & -13 & 78 & -10 & 75 \\
\hline $27-1313$ & Mount Olive Twp. Water Department 1 & 57 & -17 & 74 & -14 & 71 \\
\hline $27-1092$ & Mount Olive Twp. Water Department 2 & 55 & -17 & 72 & -14 & 69 \\
\hline $27-1093$ & Mount Olive Twp. Water Department 3 & 77 & -15 & 92 & -12 & 89 \\
\hline
\end{tabular}

1 Negative value indicates water-level decline. Positive value indicates water-level rise.

2 The change in the pumping water level would be primarily a response to decreased rate of pumpage from this well, and would be greater than the simulated average 10 -foot rise for the entire area represented by the model cell block. 
Changes in water levels in the lower valley-fill aquifer under the two scenarios also were simulated; these changes are shown in figures 59 and 60 . The greatest water-level declines under both scenarios would be in two areas northeast of the hypothetical well field, where the lower valley-fill aquifer is believed to be in better hydraulic connection with the carbonate- rock aquifer than it is at the hypothetical well-field site. Water-level declines in the lower valley-fill aquifer in the vicinity of the hypothetical well field would be smaller than in the carbonate-rock aquifer because the two aquifers are not well-connected there.

Under scenario $B$, average water levels in the lower valley-fill aquifer over parts of the Lamington River Basin would rise in response to the decrease in pumpage from the Alamatong well field. The greatest water-level rise would be $10 \mathrm{ft}$ in the area around Alamatong well 4 .

Water-level changes throughout the upper valley-fill aquifer under scenario A would be less than $1 \mathrm{ft}$. Under scenario B, water levels in the upper valley-fill aquifer would rise only slightly, up to $2 \mathrm{ft}$, in the Alamatong well field as a result of the decrease in pumpage from the underlying aquifers there.

\section{Base flow}

Base-flow depletion at four streamflow-measurement locations was estimated by comparing simulated base flows under the two scenarios with simulated base flow under recent conditions. Simulated base flow was determined for each scenario by summing tributary throughflow (estimated previously) and simulated base-flow gains, and then subtracting simulated streamflow loss upstream from a given streamflow-measurement location. Streamflow-measurement stations on Drakes Brook, the South Branch Raritan River, and the Lamington River were selected for comparison because results of simulations indicate that base-flow-depletion effects would be greatest at these locations.

Simulated base-flow depletion is summarized in table 12. The magnitude of predicted depletion can be compared with low-flow statistics determined from historical low flows at the same locations. Average base-flow depletion in Drakes Brook at Reger Road, South Branch Raritan River at Califon, and Lamington River at Ironia would be less than 12 percent under either scenario. Despite the proximity of the site on Drakes Brook to the hypothetical well field, base flow at this site would not be depleted to a great extent by additional pumping as a result of the poor hydraulic connection in this area between the carbonate-rock aquifer and the overlying lower valley-fill aquifer, which discharges to Drakes Brook. The greatest base-flow depletion under either of the scenarios would be observed downvalley from the area where the lower confining unit pinches out, more than $2 \mathrm{mi}$ southwest of the hypothetical well field, at the streamflow-measurement station Drakes Brook at Bartley (01396180). At this station, average base flow would decline from $20.5 \mathrm{ft}^{3} / \mathrm{s}$ to $15.2 \mathrm{ft}^{3} / \mathrm{s}$, or 26 percent, under scenario A. Under scenario B the decline would be 22 percent. The magnitude of base-flow depletion under either scenario would approach the estimated 7-day, 2-year low flow of $6.9 \mathrm{ft}^{3} / \mathrm{s}$ at this station, and would equal or exceed the estimated 7-day, 10-year low flow of $4.6 \mathrm{ft}^{3} / \mathrm{s}$. The predicted declines represent changes in long-term average base flow-not changes in seasonal low flows; nevertheless, the magnitude of simulated average base-flow depletion in relation to historical low flows indicates that the effect of additional pumpage under these two scenarios may substantially deplete seasonal low flows in this part of Drakes Brook. Any part of the additional pumped water that is returned to the surface- water system as treated wastewater upstream from affected reaches would lessen the depletion effects of the pumpage on low flows of those reaches.

Base-flow depletion would be greatest at a considerable distance from the hypothetical well field. Figure 61 shows the model cells in which base-flow depletion was greatest under scenario A. A similar pattern of depletion would result from scenario B pumpage. This figure indicates that base-flow depletion would be greatest in the reach from Drakes Brook near Bartley downstream to the South Branch Raritan River near Naughright. 


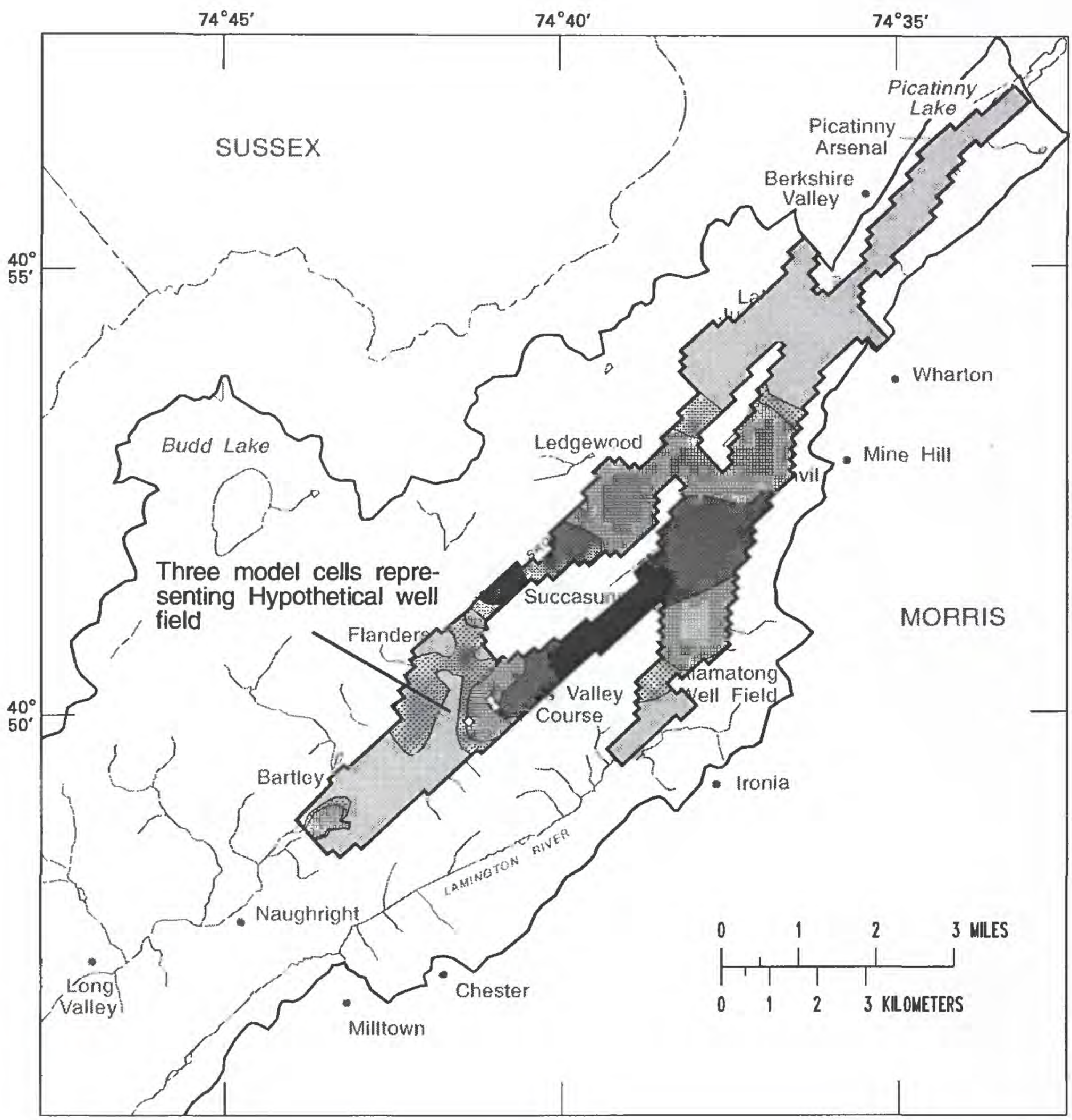

\section{EXPLANATION}

CHANGE IN AVERAGE WATER LEVEL, IN FEET

(negative values indicate water-level decline,

$>$ greater than, $\leq$ less than or equal to)

$$
\begin{aligned}
& \square>-10 \text { to } \leq-6 \text { 局 }>-2 \text { to } \leq-1 \\
& >-6 \text { to } \leq-4 \quad \square>-1 \text { to } \leq 0 \\
& >-4 \text { to } \leq-2 \quad>\begin{array}{l}
\text { Extent of model layer } 2, \\
\text { representing the lower } \\
\text { valley-fill aquifer }
\end{array}
\end{aligned}
$$

Figure 59. Simulated change in average water levels in the lower valley-fill aquifer resulting from an additional withdrawal of 5.7 million gallons per day from a hypothetical well field tapping the carbonaterock aquifer. 


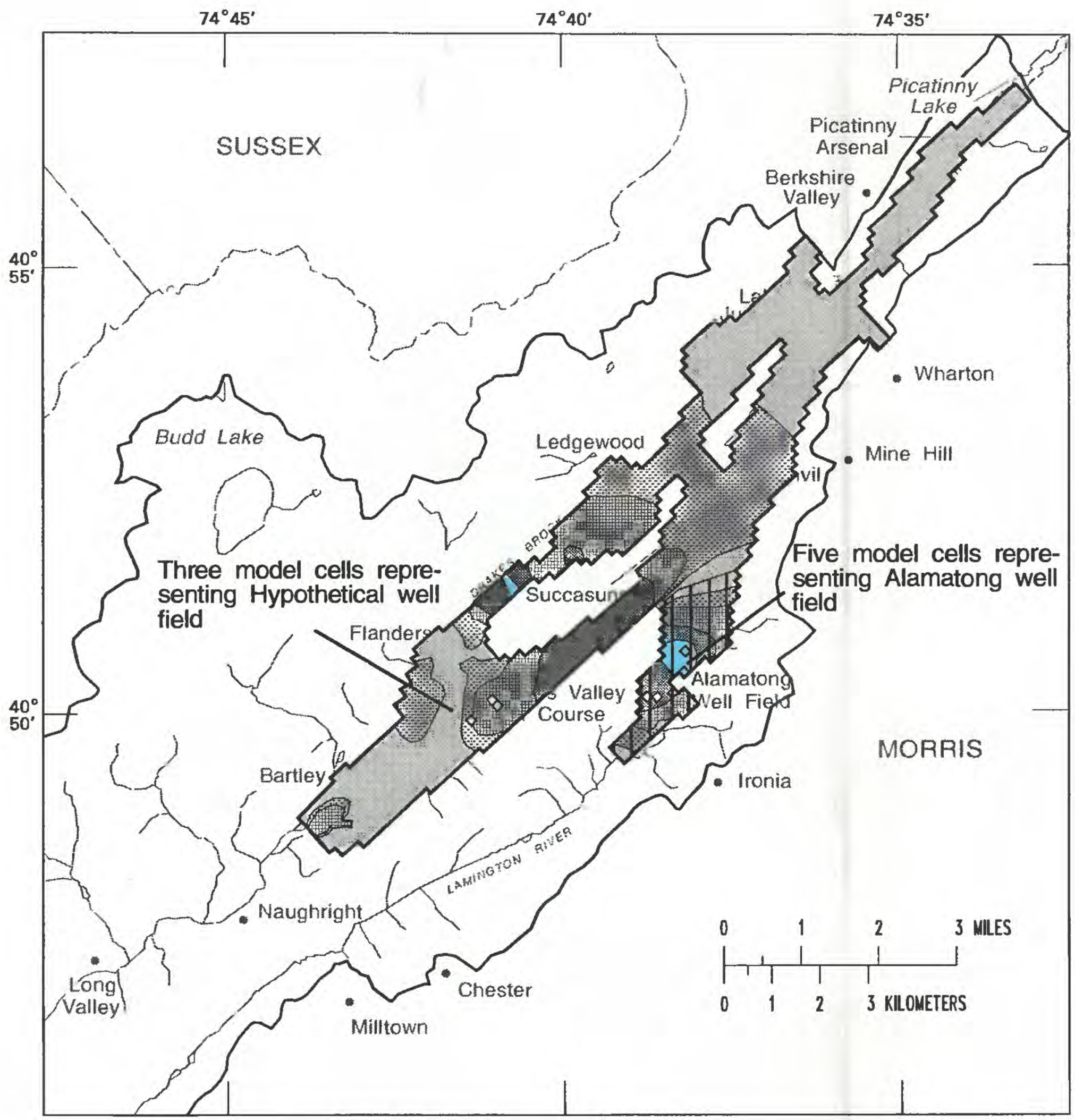

\section{EXPLANATION}

CHANGE IN AVERAGE WATER LEVEL, IN FEET

(Positive values indicate water level rise in response

to decreased pumpage from Alamatong well field.

Negative values indicate water-level decline,

$>$ greater than, < less than or equal to)

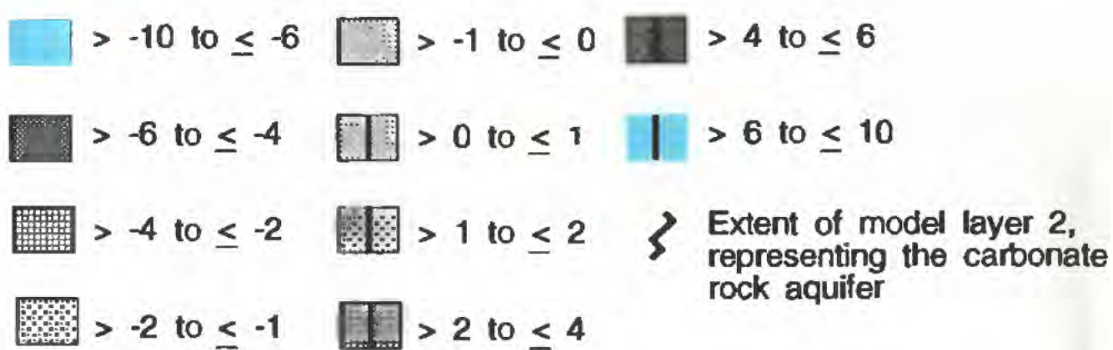

Figure 60. Simulated change in average water levels in the lower valley-fill aquifer resulting from an additional withdrawal of 4.8 million gallons per day from a hypothetical well field tapping the carbonaterock aquifer and a decrease in withdrawals of 1.3 million gallons per day from the Alamatong well field. 
Table 12. Simulated base-flow changes, characteristic low flows, and statutory minimum passing flows at four streamflow-measurement locations

[All flows and changes in flow are in cubic feet per second]

\begin{tabular}{|c|c|c|c|c|c|c|c|c|c|c|c|}
\hline \multirow[b]{2}{*}{$\begin{array}{l}\text { Station } \\
\text { number }\end{array}$} & \multirow[b]{2}{*}{ Description } & \multirow[b]{2}{*}{$\begin{array}{c}\text { Simulated } \\
\text { recent } \\
\text { base flow }\end{array}$} & \multicolumn{3}{|c|}{ Scenario A } & \multicolumn{3}{|c|}{ Scenario B } & \multicolumn{2}{|c|}{$\begin{array}{l}\text { Characteristic } \\
\text { low flows }\end{array}$} & \multirow{2}{*}{$\begin{array}{c}\text { Statutory } \\
\text { minimum } \\
\text { passing } \\
\text { flow }^{3}\end{array}$} \\
\hline & & & $\begin{array}{l}\text { Simulated } \\
\text { base flow }\end{array}$ & $\begin{array}{l}\text { Simulated } \\
\text { base-flow } \\
\text { change }\end{array}$ & $\begin{array}{l}\text { Percent } \\
\text { change }\end{array}$ & $\begin{array}{l}\text { Simulated } \\
\text { base flow }\end{array}$ & $\begin{array}{l}\text { Simulated } \\
\text { base-flow } \\
\text { change }\end{array}$ & $\begin{array}{l}\text { Percent } \\
\text { change }\end{array}$ & $\begin{array}{l}\text { 7-day, } \\
\text { 2-year }{ }^{1}\end{array}$ & $\begin{array}{l}\text { 7-day, } \\
\text { 10-year }\end{array}$ & \\
\hline 01396160 & $\begin{array}{l}\text { Drakes Brook } \\
\text { at Reger Road }\end{array}$ & 10.3 & 9.7 & -0.6 & 6 & 9.8 & -0.5 & 5 & 6.2 & 3.8 & 2.2 \\
\hline 01396180 & $\begin{array}{l}\text { Drakes Brook } \\
\text { at Bartley }\end{array}$ & 20.5 & 15.2 & -5.3 & 26 & 15.9 & -4.6 & 22 & 6.9 & 4.6 & 3.2 \\
\hline 01396350 & $\begin{array}{l}\text { South Branch } \\
\text { Raritan River at } \\
\text { Califon }\end{array}$ & 79.6 & 71.2 & -8.4 & 11 & 72.5 & -7.1 & 9 & 19.7 & 11.4 & 11.3 \\
\hline 01399200 & $\begin{array}{l}\text { Lamington } \\
\text { River near } \\
\text { Ironia }\end{array}$ & 10.2 & 9.8 & -.4 & 4 & 10.2 & 0 & 0 & 4.2 & 1.8 & 2.1 \\
\hline
\end{tabular}

1 7-day, 2-year low flow estimated from low-flow correlations with index stations (see table 8 for equations). For all but Lamington River station, index station used was South Branch Raritan River at High Bridge (01396500). Estimated 7-day, 2-year low flow for South Branch Raritan River at High Bridge is $32 \mathrm{ft}^{3} / \mathrm{s}$ (Gillespie and Schopp, 1982, p.58). For Lamington River near Ironia, the index station used was Lamington River near Pottersville (01399500). Estimated 7-day, 2-year low flow for Lamington River near Pottersville is $12 \mathrm{ft}^{3} / \mathrm{s}$ (Gillespie and Schopp, 1982, p.65).

\footnotetext{
2 7-day, 10-year low flow estimated from low-flow correlations with index stations (see table 8 for equations). For all but Lamington River station, index station used was South Branch Raritan River at High Bridge (01396500). Estimated 7-day, 10-year low flow for South Branch Raritan River at High Bridge is $21 \mathrm{ft}^{3} / \mathrm{s}$ (Gillespie and Schopp, 1982, p.58). For Lamington River near Ironia, the index station used was Lamington River near Pottersville (01399500). Estimated 7-day, 10-year low flow for Lamington River near Pottersville is $4.8 \mathrm{ft}^{3} / \mathrm{s}$ (Gillespie and Schopp, 1982, p.65).

${ }^{3}$ Statutory minimum passing flows were determined by multiplying a factor of 0.125 million gallons per day per square mile by drainage area, in square miles, and converting flow to units of cubic feet per second.
} 


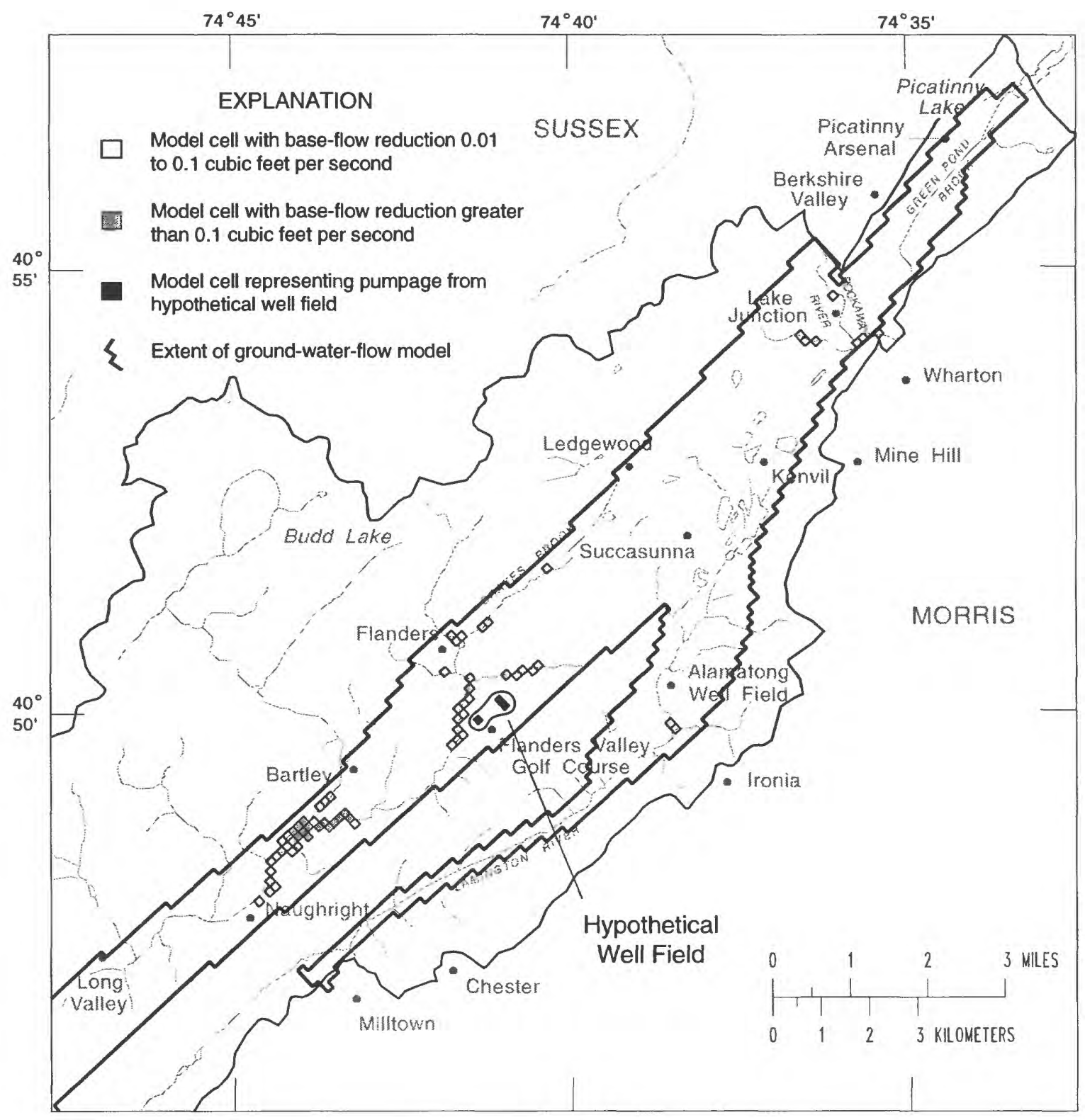

Figure 61. Location of greatest simulated base-flow reduction resulting from an additional withdrawal of 5.7 million gallons per day from a hypothetical well field tapping the carbonate-rock aquifer. 
Results of simulations were used to estimate changes in the water budget that would result from additional ground-water withdrawals. The simulated water-budget changes provide an indication of the sources of water available to additional supply wells. Budget analyses of simulation results for scenarios $A$ and $B$ indicate that water-budget changes, most notably base-flow depletion, would be substantial within the drainage area of the South Branch Raritan River, whereas changes in the water budgets of the Lamington and Rockaway River Basins would be small. For this reason, only the simulated water-budget changes in the modeled part of the South Branch Raritan River Basin (fig. 62) are presented in figure 63. These changes were determined from simulated budgets for the part of the flow system within the South Branch Raritan River Basin, which were analyzed by using the computer program of Harbaugh (1990b).

This budget analysis shows that, under the two scenarios, the budget of the upper valley-fill aquifer within the South Branch Raritan River basin would not change substantially because this aquifer is hydraulically isolated from the underlying aquifers in the basin, and because neither scenario included additional pumpage from the upper valley-fill aquifer.

Simulated budget changes in the lower valley-fill aquifer within the South Branch Raritan River Basin are (1) decreased discharge to rivers, (2) increased leakage from tributary streams, (3) increased downward flow to the carbonate-rock aquifer, and (4) decreased upward flow from the carbonate- rock aquifer. Under present conditions, the upward flow from the carbonate- rock aquifer discharges primarily from the lower valley-fill aquifer to rivers. Increased river leakage to and decreased river discharge from the lower valley-fill aquifer would be responsible for most of the base-flow depletion in Drakes Brook and the South Branch Raritan River described earlier.

Simulated budget changes in the carbonate-rock aquifer within the South Branch Raritan River Basin are (1) decreased discharge to rivers; (2) increased downward flow from and decreased upward flow to the lower valley- fill aquifer, as described above; (3) increased lateral flow into the basin from the Lamington River Basin; and (4) slightly increased leakage from tributary streams. Increased river leakage and decreased river discharge would be responsible for the rest of the simulated base-flow depletion in Drakes Brook and the South Branch Raritan River.

Under scenario A, the primary source of the additional $8.8 \mathrm{ft}^{3} / \mathrm{s}$ withdrawn from the hypothetical well field would be a $6.9 \mathrm{ft}^{3} / \mathrm{s}$ decrease in discharge to Drakes Brook and the South Branch Raritan River from the lower valley-fill and carbonate-rock aquifers. The source of the remaining water would be increased river leakage $\left(1.2 \mathrm{ft}^{3} / \mathrm{s}\right)$ and increased lateral inflow of ground water from the Lamington River Basin $\left(0.7 \mathrm{ft}^{3} / \mathrm{s}\right)$. Under scenario B, the primary source of the additional $7.5 \mathrm{ft}^{3} / \mathrm{s}$ withdrawn from the hypothetical well field would be a 5.7- $\mathrm{ft}^{3} / \mathrm{s}$ decrease in discharge to Drakes Brook and the South Branch Raritan River from the lower valley-fill and carbonate-rock aquifers. The source of the remaining water would be increased river leakage $\left(1.1 \mathrm{ft}^{3} / \mathrm{s}\right)$ and increased lateral inflow of ground water from the Lamington River Basin $\left(0.7 \mathrm{ft}^{3} / \mathrm{s}\right)$. Under either scenario, the $0.7-\mathrm{ft}^{3} / \mathrm{s}$ increase in lateral flow from the Lamington River Basin into the South Branch Raritan River Basin would not constitute a substantial change to the water budget of the Lamington River Basin.

\section{FUTURE MONITORING OF HYDROLOGIC EFFECTS OF ADDITIONAL WITHDRAWALS}

The predicted effects of additional ground-water-supply development on water levels, base flow, and the water budget are based on analysis of the responses of the hydrologic system to recent and historic conditions. Actual responses to additional development can be monitored by means of a data-collection network that is designed to provide early warning of adverse effects so that the quantity and quality of the water resource can be maintained. 


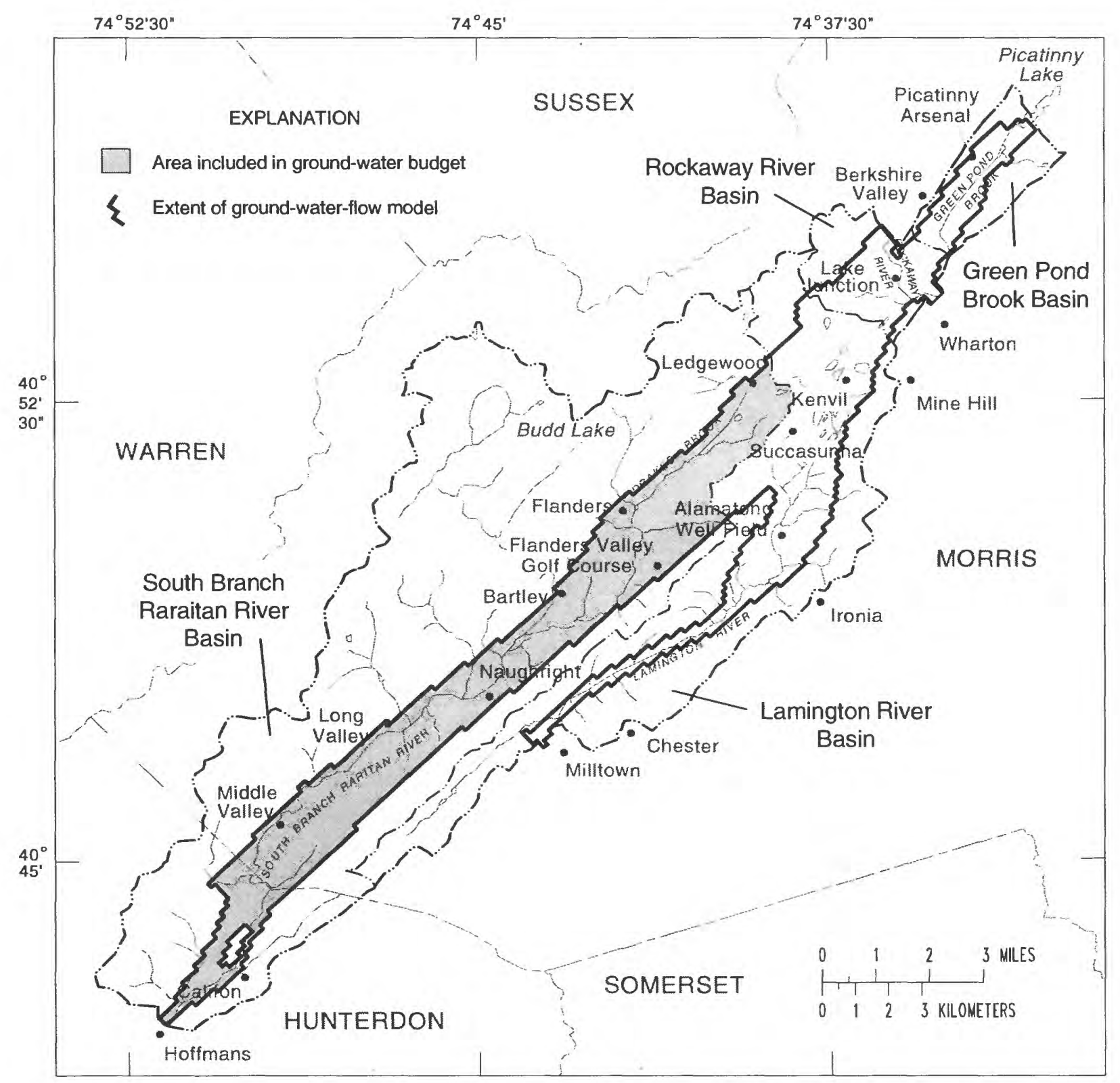

Figure 62. Part of the South Branch Raritan River Basin included in the analysis of simulated groundwater budgets under various flow conditions. 
FLOW, IN CUBIC FEET PER SECOND

OUTFLOW

INFLOW

Recharge

To / from rivers

To underlying aquifer

Lateral flow to Lamington

River drainage area

Withdrawals

Recharge

To / from nivers

From overlying aquifer

To / from underlying aquifer
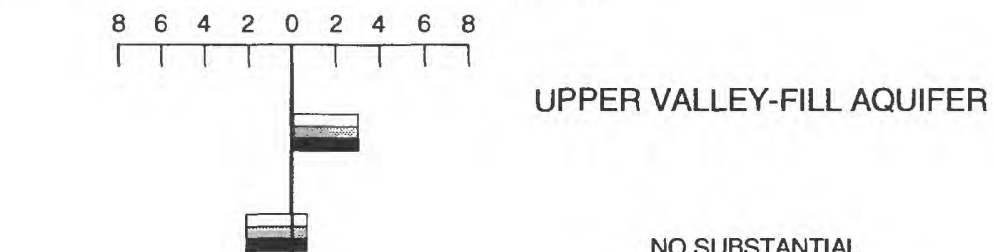

NO SUBSTANTIAL

CHANGE IN BUDGET

EXPLANATION

Recent conditions

Scenario A

Scenario B

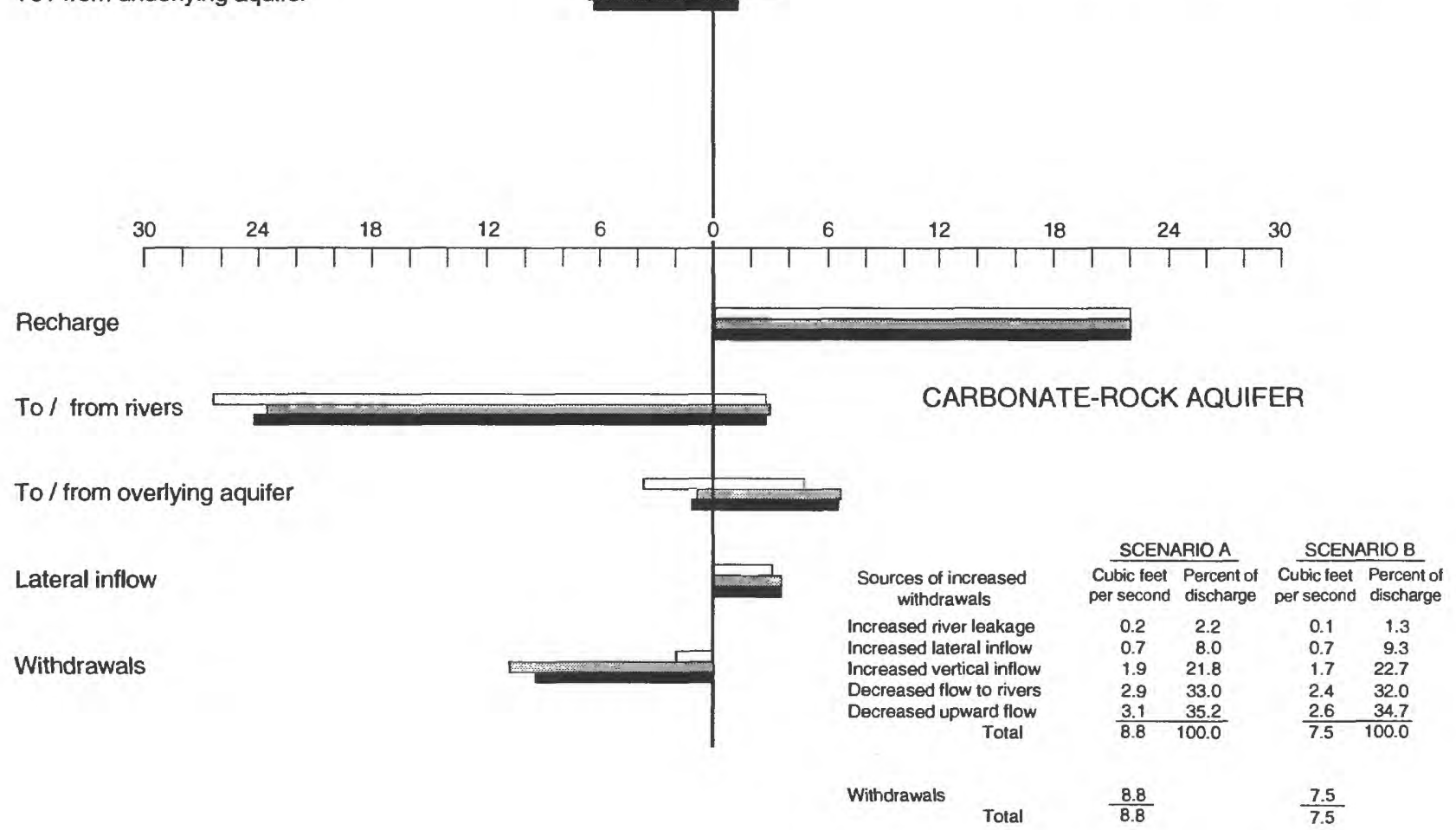

Figure 63. Simulated ground-water budgets for the South Branch Raritan River Basin under recent average conditions and under conditions simulated in Scenarios A and B. (Area included in budget shown in fig. 62) 
Most of the additional development of ground-water supply within the study area is anticipated to rely on confined aquifers north of Bartley. Some changes in water supply and wastewater management are also anticipated in the uplands upstream from Bartley, near Budd Lake (Joseph Mattle, New Jersey Department of Environmental Protection and Energy, written commun., 1992). The effects of additional withdrawals from confined aquifers underlying the South Branch Raritan River drainage basin can be monitored by means of a data-collection network. The effects of these withdrawals on streamflow, particularly low flows, can be monitored by means of a long-term continuous-record streamflow-gaging station on the South Branch Raritan River near Naughright. The effects of water-supply development on well yields can be monitored by measuring water levels in observation wells. Frequent measurements can be used to detect long-term trends to indicate whether water levels will decline below pump intakes of nearby users, or whether water levels will decline below either the bottom of overlying confining units or the bottom of densely fractured zones.

In other parts of the study area, ground-water withdrawals from confined aquifers that are overlain by a leaky or discontinuous confining unit are likely to continue. The flow of water of undesirable quality can be monitored by means of water-quality sampling and water-level measurements at observation-well nests consisting of a well that is open to the water table and a well that is open to each confined aquifer.

In parts of the study area where withdrawals from an unconfined aquifer are anticipated to begin or continue, flow in the nearest stream can be measured to monitor base-flow depletion. Water samples can be collected from observation wells located between the pumped well and the stream to evaluate whether water of undesirable quality is flowing toward pumped wells.

\section{SUMMARY AND CONCLUSIONS}

The valley-fill and carbonate-rock aquifer system near Long Valley, New Jersey, is an important source of ground water in southwestern Morris and northeastern Hunterdon Counties, where demand for water is increasing. The USGS, in cooperation with the New Jersey Department of Environmental Protection, conducted a study during 1987-90 to address concerns about the adequacy of the aquifer system to supply increasing water demand. The study included an assessment of the hydrogeology of the area and the use of numerical-modeling techniques to evaluate the ground-water-flow system and the factors that limit water-supply availability.

The aquifer system consists of the upper and lower valley-fill aquifers, two valley-fill confining units, the Paleozoic confining unit, and the carbonate-rock aquifer. Estimated hydraulic conductivities of the valley-fill aquifers are comparable and range from 2 to $130 \mathrm{ft} / \mathrm{d}$. Estimated hydraulic conductivities of the carbonate-rock aquifer, which is characterized by lateral anisotropy, span a much larger range. Estimated leakance between aquifers is highest in areas where intervening confining units are absent.

Recharge to the aquifer system is by direct infiltration of precipitation, leakage from surface-water bodies, infiltration of runoff from adjacent upland areas, and lateral flow from adjacent buried valleys. Ground water discharges from the system as flow to surface-water bodies, lateral flow to adjacent buried valleys, and withdrawals from wells. Under present-day conditions, downward leakage from the upper valley-fill aquifer to underlying aquifers is $8.2 \mathrm{ft}^{3} / \mathrm{s}$. Downward leakage from the lower valley-fill aquifer to the carbonate-rock aquifer is $8.3 \mathrm{ft}^{3} / \mathrm{s}$. Ground water flows out of the Lamington River Basin into the South Branch Raritan River Basin at a rate of about $3.0 \mathrm{ft}^{3} / \mathrm{s}$.

Water-quality data indicate that human activities have affected ground- water quality, particularly in the northern and central parts of the study area. With the exception of an elevated iron concentration in water from one well, concentrations of inorganic constituents in water from 75 wells sampled did not exceed New Jersey primary or secondary drinking-water regulations. Volatile organic compounds were detected in water from several wells; in two samples, concentrations of specific compounds exceeded drinking-water regulations. 
Both transient and steady-state ground-water-flow conditions were analyzed using numericalmodeling techniques. Simulated steady-state water levels, gradients, and base flows generally were consistent with those observed under recent steady conditions. Transient flow during two aquifer tests of the carbonate-rock aquifer was analyzed using the numerical flow model developed for this study. Simulated and measured transient drawdowns agreed closely at each of six observation wells.

The effects of present and anticipated future withdrawals from the carbonate-rock aquifer on stream base flows, water levels, and the overall water budget were estimated. Simulation results indicate that recent withdrawals have caused flow directions to change in some areas, and have resulted in waterlevel declines of up to $35 \mathrm{ft}$ near pumping centers. In other areas, flow directions and water levels have remained virtually unchanged. Under conditions of projected increases in ground-water withdrawals of 121 percent, average water levels in the carbonate-rock aquifer would decline up to $28 \mathrm{ft}$, but pumping water levels in two public supply wells in the affected area would not approach the depths of present pump intakes. The magnitude of predicted average base-flow depletion, when compared with historic low flows, indicates that projected increases in pumpage may substantially deplete seasonal low flow of Drakes Brook and the South Branch Raritan River. Average base flow of Drakes Brook at Bartley would decrease from $20.5 \mathrm{ft}^{3} / \mathrm{s}$ by as much as $5.3 \mathrm{ft}^{3} / \mathrm{s}$, or 26 percent. Historically, low flows at this location have been less than $5.3 \mathrm{ft}^{3} / \mathrm{s}$.

Water-budget changes that would result from increased withdrawals from the carbonate-rock aquifer include (1) decreased discharge to rivers from the aquifer system, (2) increased downward flow from and decreased upward flow to the lower valley-fill aquifer, (3) increased lateral flow of ground water into the South Branch Raritan River Basin from the Lamington River Basin, and (4) a slight increase in tributary stream leakage to the aquifer system. These water-budget changes indicate the sources of water to additional supply wells.

A data-collection program designed for early detection of potential adverse effects of water-supply development would include (1) continuous gaging of streamflow in the South Branch Raritan River near Naughright, (2) frequent measurement of water levels in nests of wells open to each aquifer, and (3) waterquality sampling in nests of wells open to each aquifer. 


\section{REFERENCES CITED}

Barnett, S.G., 1976, Geology of the Paleozoic rocks of the Green Pond outlier: New Jersey Geological Report Series, no. $11,9 \mathrm{p}$.

Barton, Cynthia, Vowinkel, E.F., and Nawyn, J.P., 1987, Preliminary assessment of water quality and its relation to hydrogeology and land use: Potomac-Raritan-Magothy aquifer system, New Jersey: U.S. Geological Survey Water-Resources Investigations Report 87-4023, 79 p.

Bauersfeld, W.R., Jones, W.D., and Pustay, E.A., 1991, Water resources data, New Jersey, water year 1990: U.S. Geological Survey Water-Data Report NJ-90-2, 178 p.

Bayley, W.S., Salisbury, R.D., and Kummel, H.B., 1914, Raritan quadrangle, [New Jersey]: U.S. Geological Survey Geologic Atlas, folio 191, 32 p., scale 1:125,000, 5 sheets.

Bear, J., and Verruijt, A., 1987, Modelling groundwater flow and pollution: Dordrecht, Holland, D. Reidel Publishing Company, $414 \mathrm{p}$.

Brahana, J.V., Thrailkill, J., Freeman, T., and Ward, W.C., 1988, Carbonate rocks, in Back, W., Rosensheim, J.S., and Seaber, P.R., eds., Hydrology: The Geology of North America, v. O-2, Boulder, Colorado, Geological Society of America, 524 p., 3 sheets.

Cooper, H.H.Jr., and Jacob, C.E., 1946, A generalized graphical method for evaluating formation constants and summarizing well field history: Transactions of the American Geophysical Union, no. 27, p.526-534.

Curtis, J.B., Jr, and Stueber, A.M., 1973, Sr-87/Sr-86 ratios and total strontium concentrations in surface waters of the Scioto River drainage basin, Ohio: The Ohio Journal of Science, v. 73, no. 3, p. 166-175.

Drake, Avery A., Jr., 1969, Precambrian and lower Paleozoic geology of the Delaware Valley, New JerseyPennsylvania, in Subitzky, Seymour, ed., Geology of selected areas in New Jersey and eastern Pennsylvania and guidebook of excursions: Geological Society of America and associated societies, November 1969, Annual Meeting, Atlantic City, N. J.: New Brunswick, New Jersey, Rutgers University Press, p. 51-132.

Eccles, L.A., and Bradford, W.L., 1977, Distribution of nitrate in ground water, Redlands, California: U.S. Geological Survey Water-Resources Investigations Report 75-117, 38 p.

Elson T. Killam Associates, Inc., 1982, Morris County Master Plan: Water Supply Element, Morristown, N.J., Morris County Planning Board, $65 \mathrm{p}$.

Faure, Gunter, 1986, Principles of isotope geology, 2nd ed.: New York, John Wiley and Sons, 589 p.

Federal Register, 1989, National primary and secondary drinking-water regulations: U.S. Environmental Protection Agency, v. 54, no.97, May 22, 1989, p. 22062.

Fishman, M.J., and Friedman, L.C., 1989, Methods for determination of inorganic substances in water and fluvial sediments: Techniques of Water-Resources Investigations of the U.S. Geological Survey, book 5 , chap. 1,545 p.

Fisher, R.S., and Stueber, A.M., 1976, Strontium isotopes in selected streams within the Susquehanna River basin: Water Resources Research, v. 12, no. 5, p. 1061-1068. 


\section{REFERENCES CITED--Continued}

Morrissey, D.J., Randall, A.D., and Williams, J.H., 1987, Upland runoff as a major source of recharge to statified drift in the glaciated northeast, in Regional aquifer systems of the United States, the Northeast Glacial Systems: American Water Resources Association Monograph Series no. 11, 20 p.

New Jersey Administrative Code, 1990a, Safe drinking-water act: State primary drinking-water regulations, Title 7 , chap. 10 , subchapter 5 , p. 10-10.1 to 10-13.

1990b, Safe drinking-water act: Secondary drinking-water regulations, Title 7, chap. 10, subchapter 7, p. 10-19 to 10-21.

New Jersey Department of Environmental Protection, 1972, Flood hazard report 10, Delineation of flood hazard areas, Raritan River basin, Drakes Brook, N.J.: Trenton, N.J., New Jersey Department of Environmental Protection, 30 p., 4 pls.

Nicholson, R.S., 1990, Progress in the evaluation of a carbonate-rock aquifer near Long Valley in the New Jersey Highlands, in Field Guide and Proceedings of the Geological Association of New Jersey, 7th Annual Meeting: Aspects of Groundwater in New Jersey, October 26-27, 1990: Compiled by Brown, J.O., and Kroll, R.L., Union, N.J., Kean College of New Jersey, p. N25-31.

Pettyjohn, W.A., and Hennings, Roger, 1979, Preliminary estimate of ground-water recharge rates, related streamflow and water quality in Ohio: Ohio State University Project Completion Report No. 552, $323 \mathrm{p}$.

Schaefer, F.L., Harte, P.T., Smith, J.A., and Kurtz, B.A., 1993, Hydrogeologic conditions in the upper Rockaway River Basin, New Jersey, 1984-1986, U.S. Geological Survey Water-Resources Investigations Report 91-4169, 103 p.

Sims, P.K., 1958, Geology and magnetite deposits of Dover District, Morris County, New Jersey: U.S. Geological Survey Professional Paper 287, p. 1-59.

Sloto, R.A., 1988, A computer method for estimating ground-water contribution to streamflow using hydrograph-separation techniques: U.S. Geological Survey National Computer Technology Meeting, Phoenix, Ariz., November 14, 1988, 11 p.

Stanford, S.D., 1989, Surficial geologic map of the Dover Quadrangle, Morris and Sussex Counties, New Jersey: New Jersey Geological Survey, Geologic Survey Map 89-2, scale 1:24,000.

Stueber, A.M., Baldwin, A.D., Curtis, J.B., Jr., Pushkar, P., and Steele, J.D., 1975, Geochemistry of strontium in the Scioto River drainage basin, Ohio: Geological Society of America Bulletin, v. 86, n. 7, p. 892-896.

Theis, C.V., 1935, The relation between the lowering of the piezometric surface and the rate and duration of discharge of a well using groundwater storage: Trans. American Geophysical Union, 2, pp. 519-524.

Turk, J.T., 1983, An evaluation of the trends in the acidity of precipitation and the related acidification of surface water in North America: U.S. Geological Survey Water-Supply Paper.2249, 18 p.

Volkert, R.A., Monteverde, D.H., and Drake, A.A., 1989, Bedrock geologic map of the Stanhope Quadrangle, Sussex and Morris Counties, New Jersey: U.S. Geological Survey Geologic Quadrangle Map GQ-1671, scale 1:24,000. 


\section{REFERENCES CITED--Continued}

Volkert, R.A., Markewicz, F.J., and Drake, A.A., 1990a, Bedrock geologic map of the Chester Quadrangle, Morris County, New Jersey: New Jersey Geological Survey, Geologic Map Series 90-1, scale $1: 24,000$.

Volkert, R.A., 1990b, Geologic map of the Proterozoic and Lower Paleozoic rocks of the Califon Quadrangle, New Jersey: New Jersey Geological Survey, Geologic Map Series 89-3, scale 1:24,000.

Voronin, L.M., 1991, Simulation of ground-water flow at Picatinny Arsenal, New Jersey, in Mallard, G.E., and Aronson, D.A., eds., U.S. Geological Survey Toxic Substance Hydrology Program-Proceedings of the technical meeting, Monterey, California, March 11-15, 1991: U.S. Geological Survey Water-Resources Investigations Report 91-4034, p. 713-720.

Wershaw, R.L., Fishman, M.J., Grabbe, R.R., and Lowe, L.E., 1987, Methods for the determination of organic substances in water and fluvial sediments: Techniques of Water-Resources Investigations of the U.S. Geological Survey, book 5, chap. A3, 80 p. 


\section{REFERENCES CITED--Continued}

Flipse, W.J., Jr., Katz, B.G., Lindner, J.B., and Markel, Richard, 1984, Sources of nitrate in ground water in a sewered housing development, central Long Island, New York: Ground Water, v. 22, no.4, p. 418-426.

Freeze, R.A., and Cherry, J.A., 1979, Groundwater: Englewood Cliffs, Prentice-Hall, Inc., New Jersey, 604 p.

Friedman, L.C., and Erdmann, D.E., 1982, Quality assurance practices for the chemical and biological analyses of water and fluvial sediments: Techniques of Water-Resources Investigations of the U.S. Geological Survey, book 5, chap. A6, 181 p.

Gill, H.E., and Vecchioli, J., 1965, Availability of ground water in Morris County, New Jersey: State of New Jersey Department of Conservation and Economic Development, Special Report 25, 37 p.

Gillespie, B.D., and Schopp, R.D., 1982, Low-flow characteristics and flow duration of New Jersey streams: U.S. Geological Survey Open-File Report 81-1110, 164 p.

Gordon, A.D., 1993, Hydrogeology of, and simulated ground-water flow in, the valley-fill aquifers of the upper Rockaway River Basin, Morris County, New Jersey: U.S. Geological Survey WaterResources Investigations Report 93-4145, 74 p.

Harbaugh, A.W., 1990a, A simple contouring program for gridded data: U.S. Geological Survey Open-File Report 90-144, 12 p.

1990b, A computer program for calculating subregional water budgets using results from the U.S. Geological Survey modular three-dimensional finite-difference ground-water flow model: U.S. Geological Survey Open-File Report 90-392, 23 p.

Harper, D.P., 1979, Geology and ground water resources of the Long Valley drainage area of New Jersey: Unpublished report on file in the Trenton, N.J., office of the New Jersey Geological Survey, 24 p.

Herman, G.C., and Mitchell, J.P., 1991, Bedrock geologic map of the Green Pond Mountain region from Dover to Greenwood Lake, New Jersey: New Jersey Geological Survey Map Series 91-2, scale $1: 24,000$.

Hill, M.C., 1985, An investigation of hydraulic conductivity estimation in a ground-water flow study of northern Long Valley, New Jersey: Princeton, N.J., Princeton University, Ph.D. dissertation, 341 p.

Hirsch, R.M., 1982, A comparison of four streamflow record extention techniques: Water Resources Research, v.18, no. 4, Aug. 1982, p. 1081-1088.

Hutchinson, W.R., 1981, A computer simulation of the glacial/carbonate aquifer in the Pequest Valley, Warren County, New Jersey: New Brunswick, N.J., Rutgers University, unpublished Master's thesis, $115 \mathrm{p}$.

Kammer, J.A., and Gibs, Jacob, 1989, An analytical technique for screening purgeable volatile organic compounds in water: U.S. Geological Survey Open-File Report 89-53, 13 p.

Kasabach, H.F., 1966, Geology and ground-water resources of Hunterdon County, New Jersey: New Jersey Department of Conservation and Economic Development Special Report 24, 128 p.

Kreitler, C.W., Ragone, S.E., and Katz, B.G., 1978, N15/N14 ratios of ground-water nitrate, Long Island, New York: Ground Water, v. 16, no. 6, p. 404-409. 


\section{REFERENCES CITED--Continued}

Lapham, W.W., 1989, Use of temperature profiles beneath streams to determine rates of vertical groundwater flow and vertical hydraulic conductivity: U.S. Geological Survey Water-Supply Paper 2337, $35 \mathrm{p}$.

Locat, Jacques, and Gelinas, Pierre, 1989, Infiltration of de-icing salts in aquifers, the Trois-Rivieres-Ouest case, Quebec, Canada: Canadian Journal of Earth Sciences, v. 26, p. 2186-2193.

Lord, D.G., Barringer, J.L., Johnsson, P.A., Schuster, P.F., Walker, R.L., Fairchild, J.E., Sroka, B.N., and Jacobsen, Eric, 1990, Hydrogeochemical data from an acidic deposition study at McDonalds Branch basin in the New Jersey Pinelands, 1983-86: U.S. Geological Survey Open-File Report 88-500, 132 p.

Louis, J.B., and Vowinkel, Eric, 1989, Effect of agricultural chemicals on ground-water quality in the New Jersey Coastal Plain, in Weighmann, D.L., ed., Proceedings of a National Research Conference, Pesticides in Terrestrial and Aquatic Environments, May 11-12, 1989, Virginia Water Resources Research Center, Virginia Polytechnic Institute and State University, p. 80-89.

Lyford, F.P., and Cohen, A.J., 1987, Estimation of water available for recharge to sand and gravel aquifers in the glaciated northeastern United States, in Regional Aquifer Systems of the United States, the Northeast Glacial Systems: American Water Resources Association Monograph Series no. 11, 20 p.

Lyttle, P.T., and Epstein, J.B., 1987, Geologic map of the Newark 1' x 2' quadrangle, New Jersey, Pennsylvania, and New York: U.S. Geological Survey Miscellaneous Investigations Series Map I-1715, scale 1:250,000, 2 sheets.

MacNish, R.D., and Randall, A.D., 1982, Stratified-driftaquifers in the Susquehanna River basin, New York: New York State Department of Environmental Conservation Bulletin 75, 68 p.

Madison, R.J., and Brunett, J.O., 1984, Overview of the occurrence of nitrate in ground water of the United States, in National Water Summary, 1984, Hydrologic events, selected water quality trends, and ground-water resources: U.S. Geological Survey Water-Supply Paper 2275, p. 93-105.

Mather, J.R., 1978, The climatic water budget in environmental analysis: Lexington, Mass., Lexington Books, $239 \mathrm{p}$.

Mazor, Emanuel, 1991, Applied chemical and isotopic groundwater hydrology: New York, Halsted Press, $274 \mathrm{p}$.

McAuley, S.D., Nicholson, R.S., Barringer, J.L., and Blyskun, G.J., 1992, Plan to evaluate the hydrogeology of the valley-fill and carbonate-rock aquifers near Long Valley in the New Jersey Highlands: New Jersey Geological Survey Open-File Report OFR 92-3, 24 p.

McClymonds, N.E., and Franke, O.L., 1972, Water transmitting properties of aquifers on Long Island, New York: U.S. Geological Survey Professional Paper 627-E.

McDonald, M.G., and Harbaugh, A.W., 1988, A modular three-dimensional ground-water flow model: Techniques of Water-Resources Investigations of the U.S. Geological Survey, book 6, chap. A1, $576 \mathrm{p}$.

Meisler, H., 1976, Computer simulation model of the Pleistocene valley-fill aquifer in southwestern Essex and southeastern Morris Counties, New Jersey: U.S. Geological Survey Water-Resources Investigations Report 83-4028, 70 p. 
[locations of wells shown on plate la]

\begin{tabular}{|c|c|c|c|c|c|c|c|}
\hline $\begin{array}{c}\text { New } \\
\text { Jersey } \\
\text { well } \\
\text { number }\end{array}$ & Owner & Local well identifier & $\begin{array}{l}\text { Lati- } \\
\text { tude } \\
\text { (dms) }\end{array}$ & $\begin{array}{l}\text { Longi- } \\
\text { tude } \\
\text { (dms) }\end{array}$ & $\begin{array}{c}\text { Prima- } \\
\text { ry } \\
\text { use } \\
\text { of } \\
\text { water }\end{array}$ & $\begin{array}{c}\text { Depth } \\
\text { of well } \\
\text { (feet) }\end{array}$ & $\begin{array}{l}\text { Aqui- } \\
\text { fer } \\
\text { code }^{2}\end{array}$ \\
\hline \multicolumn{8}{|c|}{ BOROUGH OF CALIFON } \\
\hline $19-0245$ & GARDEN STATE WATER CO & CALIFON 2 & 404259 & 0744958 & $\mathbf{P}$ & 265 & 400PCMB \\
\hline $19-0254$ & JONES, DAVID & JONES DOM & 404318 & 0745004 & $\mathrm{H}$ & 123 & 374LSVL \\
\hline $19-0286$ & PHILLIPS, STAN & PHILLIPS DOM & 404303 & 0744954 & $\mathrm{H}$ & 270 & 374LSVL \\
\hline $19-0287$ & $\begin{array}{l}\text { PERKOWSKY, FRANK - PERKOWSKY BUILD- } \\
\text { ERS, INC }\end{array}$ & PERKOWSKY BUILDERS 1 & 404315 & 0745032 & $\mathbf{P}$ & 547 & 374LSVL \\
\hline \multicolumn{8}{|c|}{ TOWNSHIP OF LEBANON } \\
\hline $19-0010$ & CALIFON W C & SPRING VALLEY 1 & 404355 & 0745111 & $\mathbf{P}$ & 545 & 400PCMB \\
\hline $19-0236$ & MILLER, CATHERINE AND JEFFREY & MILLER 1 & 404432 & 0745156 & $\mathrm{H}$ & 200 & $400 \mathrm{PCMB}$ \\
\hline $19-0237$ & KENNEDY, ED & KENNEDY 1 & 404252 & 0745055 & $\mathrm{H}$ & 100 & 374LSVL \\
\hline $19-0252$ & BAUMGARTNER, JOSEPH & $\begin{array}{l}\text { BAUMGARTNER DOM } \\
\text { REPLACE }\end{array}$ & 404216 & 0745149 & $\mathrm{H}$ & 150 & 374LSVL \\
\hline $19-0253$ & BATSON, DOROTHY & BATSON 234 RT 513 & 404314 & 0745110 & $\mathrm{H}$ & 150 & $400 \mathrm{PCMB}$ \\
\hline $19-0256$ & BARKMAN, TOBY & $\begin{array}{l}\text { BARKMAN RT } 513 \\
\text { STANDBY }\end{array}$ & 404431 & 0744958 & $\mathrm{C}$ & 198 & 374LSVL \\
\hline 19-0284 & SCHEFFER, HERBERT \& ELISE & MARTINO 1 & 404440 & 0745028 & $\mathbf{H}$ & 148 & 374LSVL \\
\hline $19-0288$ & SANDORFF, JOHN DANIEL. & SANDORFF DOM & 404234 & 0745124 & $\mathrm{H}$ & 75 & 374LSVL \\
\hline $19-0289$ & LAURIE, ELIZABETH & LAURIE DOM & 404241 & 0745116 & $\mathrm{H}$ & 100 & 374LSVL \\
\hline $19-0290$ & PEAL, JOANNE AND HAROLD & BILL BRI INC 1 & 404301 & 0745055 & $\mathrm{H}$ & 135 & 374LSVL \\
\hline $19-0291$ & YOUNG, FRANK & YOUNG DOM & 404307 & 0745112 & $\mathrm{H}$ & 150 & 374LSVL \\
\hline $19-0292$ & MOULTON, ALBERTA & LEA 1-MOULTON DOM & 404314 & 0745102 & $\mathbf{H}$ & 148 & 374LSVL \\
\hline $19-0293$ & DICHECK, JAMES & ROSS DOM & 404355 & 0745026 & $\mathrm{H}$ & 400 & 374LSVL \\
\hline 19-0294 & HARRISON, HARRY & HARRISON DOM & 404436 & 0744939 & $\mathrm{H}$ & 250 & 374LSVL \\
\hline 19-0295 & FRECK, DOUG & FRECK DOM & 404441 & 0745036 & $\mathrm{H}$ & 72 & 374LSVL \\
\hline 19-0299 & ZUKOWSKI, RAY & $\begin{array}{l}\text { HOFFMANS CROSSING } \\
\text { DOM }\end{array}$ & 404227 & 0745141 & $\mathrm{H}$ & 175 & 374LSVL \\
\hline \multicolumn{8}{|c|}{ TOWNSHIP OF TEWKESBURY } \\
\hline $19-0238$ & SEICKEL, STEVE & SEICKEL 1 & 404423 & 0744752 & $\mathrm{H}$ & 300 & 400РCMB \\
\hline $19-0255$ & MERRILL, LEWIS & MERRILL DOM & 404354 & 0744945 & $\mathrm{H}$ & 71 & $112 \mathrm{SFDF}$ \\
\hline $19-0296$ & ARMSTRONG, GEORGE AND JOANNE & ARMSTRONG DOM FAKE & 404355 & 0744939 & $\mathbf{H}$ & 118 & $112 \mathrm{SFDF}$ \\
\hline $19-0297$ & BEAM, SARAH & BEAM DOM & 404359 & 0744941 & $\mathrm{H}$ & 110 & 374LSVL \\
\hline $19-0298$ & TESKA, HEINTZ & $\begin{array}{l}\text { SAMOS CONSTRUCTION } \\
\text { DOM }\end{array}$ & 404413 & 0744820 & $\mathrm{H}$ & 165 & 374LSVL \\
\hline \multicolumn{8}{|c|}{ TOWNSHIP OF CHESTER } \\
\hline $27-1089$ & CHUDOBA, ELIZABETH AND WILLIAM & CHUDOBA 1 & 404955 & 0743922 & $\mathbf{H}$ & 102 & 112 SFDF \\
\hline $27-1090$ & MORRIS COUNTY MUA & MORRIS CO MUA 5 & 405009 & 0743847 & $\mathbf{P}$ & 514 & 374LSVL \\
\hline $27-1125$ & US GEOLOGICAL SURVEY & BLACK RIVER 3 OBS & 404934 & 0743859 & $\mathrm{U}$ & 419 & 374LSVL \\
\hline $27-1126$ & US GEOLOGICAL SURVEY & BLACK RIVER 4 OBS & 404809 & 0744155 & $\mathrm{U}$ & 237 & 374LSVL \\
\hline $27-1164$ & US GEOLOGICAL SURVEY & BLACK RIVER 5 OBS & 404809 & 0744155 & $\mathbf{U}$ & 49 & 112 SFDF \\
\hline
\end{tabular}




\begin{tabular}{|c|c|c|c|c|c|c|c|}
\hline $\begin{array}{c}\text { New } \\
\text { Jersey } \\
\text { well } \\
\text { number }\end{array}$ & Owner & Local well identifier & $\begin{array}{l}\text { Lati- } \\
\text { tude } \\
(\mathrm{dms})\end{array}$ & $\begin{array}{l}\text { Longi- } \\
\text { tude } \\
\text { (dms) }\end{array}$ & $\begin{array}{c}\text { Prima- } \\
\text { ry } \\
\text { use } \\
\text { of } \\
\text { water }^{1}\end{array}$ & $\begin{array}{c}\text { Depth } \\
\text { of well } \\
\text { (feet) }\end{array}$ & $\begin{array}{l}\text { Aqui- } \\
\text { fer } \\
\text { code }^{2}\end{array}$ \\
\hline \multicolumn{8}{|c|}{ TOWNSHIP OF CHESTER--Continued } \\
\hline $27-1190$ & STATE OF NJ & BLACK RIVER 10 OBS & 404934 & 0744005 & $\mathrm{U}$ & 200 & 400PCMB \\
\hline $27-1555$ & KEATING, JOHN AND LYNN & CALEB DEVEL CORP 751 & 404659 & 0744340 & $\mathrm{H}$ & 200 & 374LSVL \\
\hline $27-1556$ & MANSOLINO, MICHAEL & CALEB DEVEL CORP 809 & 404714 & 0744340 & $\mathbf{H}$ & 200 & 377HRDS \\
\hline $27-1557$ & $\begin{array}{l}\text { SIMMONDS PRECISION/CO-OPERATIVE } \\
\text { INDUSTRIES }\end{array}$ & SIMMONDS IND RW-1 & 404749 & 0744207 & $\mathrm{U}$ & 116 & 377HRDS \\
\hline $27-1558$ & $\begin{array}{l}\text { SIMMONDS PRECISION/CO-OPERATIVE } \\
\text { INDUSTRIES }\end{array}$ & SIMMONDS IND MW B-7A & 404750 & 0744206 & $\mathrm{U}$ & 25 & $112 \mathrm{SFDF}$ \\
\hline $27-1559$ & $\begin{array}{l}\text { SIMMONDS PRECISION/CO-OPERATIVE } \\
\text { INDUSTRIES }\end{array}$ & SIMMONDS IND RW-4 & 404756 & 0744201 & $\mathrm{U}$ & 101 & 400PCMB \\
\hline $27-1560$ & $\begin{array}{l}\text { SIMMONDS PRECISION/C0-OPERATIVE } \\
\text { INDUSTRIES }\end{array}$ & SIMMONDS IND MW B-12 & 404756 & 0744202 & $\mathrm{U}$ & 20 & $112 \mathrm{SFDF}$ \\
\hline $27-1561$ & FENNELL, KEVIN & FENNELL DOM & 404809 & 0744324 & $\mathrm{H}$ & 118 & 112SFDF \\
\hline $27-1562$ & MORRIS COUNTY MUA & MCMUA TW 3 ALAMATONG & 405008 & 0743845 & $\mathbf{U}$ & 310 & 374LSVL \\
\hline $27-1563$ & SMOLINSKY, FRED & SMOLINSKY 1 & 405008 & 0743849 & $\mathrm{H}$ & 172 & 374LSVL \\
\hline $27-1564$ & HUBER, MARY AND MERRILL & HUBER DOM 1986 & 405010 & 0743900 & $\mathrm{H}$ & 375 & 374LSVL \\
\hline $27-1705$ & MORRIS COUNTY MUA & MCMUA B-9 & 404952 & 0743848 & $\mathrm{U}$ & 130 & $112 \mathrm{SFDF}$ \\
\hline \multicolumn{8}{|c|}{ TOWNSHIP OF DOVER } \\
\hline $27-0083$ & PICATINNY ARSENAL & US ARMY-PICATINNY 302D & 405632 & 0743359 & $\mathrm{U}$ & 404 & 374LSVL \\
\hline \multicolumn{8}{|c|}{ TOWNSHIP OF MINE HILL } \\
\hline $27-1565$ & MIGNECO, JOHN & SARNOWSKI DOM & 405239 & 0743655 & $\mathrm{H}$ & 140 & $112 \mathrm{SFDF}$ \\
\hline $27-1566$ & HENRIQUEZ, JAIME AND YOLANDA & SUNDIAL HOMES 1 & 405240 & 0743654 & $\mathbf{H}$ & 157 & $112 \mathrm{SFDF}$ \\
\hline $27-1567$ & ALBERTO, ENGRACIO & POBURSKI BURIED & 405242 & 0743647 & $\mathrm{U}$ & 117 & $112 \mathrm{SFDF}$ \\
\hline $27-1568$ & DEMETRO, JOSEPH & DEMETRO 1 & 405243 & 0743647 & $\mathbf{H}$ & 273 & 374LSVL \\
\hline $27-1569$ & COOK, EMMA & COOK BURIED DOM & 405245 & 0743645 & $\mathrm{H}$ & 123 & 1I2SFDF \\
\hline $27-1570$ & COUNTRY LAKES ANIMAL CLINIC & $\begin{array}{l}\text { COUNTRY LAKES CLINIC } \\
\text { DOM }\end{array}$ & 405245 & 0743646 & $\mathbf{H}$ & 300 & 374LSVL \\
\hline $27-1571$ & TEXACO INC & TEXACO 12 & 405248 & 0743558 & $\mathbf{U}$ & 17.5 & $112 \mathrm{SFDF}$ \\
\hline $27-1572$ & MELILLO, JAMES & MELILLO DOM & 405249 & 0743644 & $\mathrm{H}$ & 100 & 112SFDF \\
\hline $27-1573$ & DAVIS, LINWOOD R & LINWOOD DOM & 405250 & 0743646 & $\mathrm{H}$ & 248 & 374LSVL \\
\hline $27-1574$ & MCGARRY, CAROL AND KAREN & ROGERS 1 & 405301 & 0743630 & $\mathrm{H}$ & 148 & $112 \mathrm{SFDF}$ \\
\hline \multicolumn{8}{|c|}{ TOWNSHIP OF MOUNT OLIVE } \\
\hline $27-1084$ & MORRIS COUNTY MUA & MCMUA TEST WELL 2 OBS & 404954 & 0744122 & $\mathrm{U}$ & 211 & 374LSVL \\
\hline $27-1091$ & WIEN LABORATORIES INC & WIEN LABORATORIES 1 & 405004 & 0744148 & $\mathbf{C}$ & 98 & $112 \mathrm{SFDF}$ \\
\hline $27-1092$ & MOUNT OLIVE TOWNSHIP & MT OLIVE TWP FLANDERS2 & 404958 & 0744237 & $\mathrm{P}$ & 198 & 374LSVL \\
\hline $27-1093$ & MOUNT OLIVE TOWNSHIP & MT OLIVE TWP FLANDERS3 & 404902 & 0744232 & $\mathrm{P}$ & 260 & 374LSVL \\
\hline $27-1101$ & GRABER, MARIE AND CHARLES & GRABER 1 & 404910 & 0744321 & $\mathrm{H}$ & 100 & 112 SFDF \\
\hline
\end{tabular}




\begin{tabular}{|c|c|c|c|c|c|c|c|}
\hline $\begin{array}{c}\text { New } \\
\text { Jersey } \\
\text { well } \\
\text { number }\end{array}$ & Owner & Local well identifier & $\begin{array}{l}\text { Lati- } \\
\text { tude } \\
\text { (dms) }\end{array}$ & $\begin{array}{l}\text { Longi- } \\
\text { tude } \\
(\mathrm{dms})\end{array}$ & $\begin{array}{c}\text { Prima- } \\
\text { ry } \\
\text { use } \\
\text { of } \\
\text { water }\end{array}$ & $\begin{array}{c}\text { Depth } \\
\text { of well } \\
\text { (feet) }\end{array}$ & $\begin{array}{l}\text { Aqui- } \\
\text { fer } \\
\text { code }^{2}\end{array}$ \\
\hline \multicolumn{8}{|c|}{ TOWNSHIP OF MOUNT OLIVE--Continued } \\
\hline $27-1102$ & BAIETTO, ALFRED AND BARBARA & BAIETTO 1 & 405010 & 0744144 & $\mathrm{H}$ & 140 & 374LSVL \\
\hline $27-1168$ & GRABOVETZ, JOHN & MARVELAND FARMS & 404949 & 0744145 & $\mathrm{H}$ & 110 & 374LSVL \\
\hline $27-1169$ & WEB DYNAMICS CO & WEB DYNAMICS IND & 405010 & 0744124 & $\mathrm{~N}$ & 140 & 112SFDF \\
\hline $27-1171$ & FLYNN, DAVID AND MARIA & FLYNN DOM & 405058 & 0744207 & $\mathrm{H}$ & 198 & 400PCMB \\
\hline $27-1313$ & MOUNT OLIVE TOWNSHIP & MT OLIVE TWP FLANDERS1 & 404955 & 0744226 & $\mathbf{P}$ & 110 & 374LSVL \\
\hline $27-1575$ & MOUNT OLIVE TOWNSHIP & MT OLIVE FLANDERS 3 MW & 404901 & 0744231 & $\mathrm{U}$ & 120 & 374LSVL \\
\hline $27-1576$ & LOJEK, JOSEPH & LOJEK DOM & 404911 & 0744317 & $\mathbf{H}$ & 132 & 112SFDF \\
\hline $27-1577$ & $\begin{array}{l}\text { PROVIDENCE DEVELOPMENT CORP - ALL } \\
\text { FLANDERS }\end{array}$ & $\begin{array}{l}\text { ALL FLANDERS SELFSTOR- } \\
\text { AGE }\end{array}$ & 404952 & 0744251 & $\mathrm{H}$ & 150 & 374LSVL \\
\hline $27-1578$ & $\begin{array}{l}\text { BYRNE, DOROTHY - BYRNE CERAMIC SUP- } \\
\text { PLY CO }\end{array}$ & BYRNE CERAMIC SUPPLY & 404956 & 0744243 & $\mathrm{C}$ & 98 & 374LSVL \\
\hline $27-1580$ & PARKS, DONALD - HOPE BAPTIST CHURCH & HOPE BAPTIST CHURCH & 405005 & 0744214 & $\mathrm{~T}$ & 150 & 374LSVL \\
\hline $27-1581$ & MERIDAN BLOCK AND SUPPLY & HAWKEYE 2 COM & 405007 & 0744119 & $\mathbf{C}$ & 140 & 374LSVL \\
\hline $27-1582$ & GARDE, MICHAEL - BON VENTURE SERVICE & BON VENTURE SERV 1988 & 405010 & 0744116 & $\mathbf{N}$ & 143 & $112 \mathrm{SFDF}$ \\
\hline $27-1583$ & SAVADGE, WILLARD G & SAVADGE DOM & 405041 & 0744134 & $\mathrm{H}$ & 98 & $112 \mathrm{SFDF}$ \\
\hline $27-1584$ & $\begin{array}{l}\text { MOUNT OLIVE TWP BOARD OF ED - } \\
\text { FLANDERS SCH }\end{array}$ & FLANDERS SCHOOL & 405043 & 0744159 & $\mathrm{~T}$ & 192 & 112SFDF \\
\hline $27-1727$ & MORRIS COUNTY MUA & FLANDERS GOLF PW & 404954 & 0744122 & $\mathbf{P}$ & 297 & 374LSVL \\
\hline $27-1729$ & FLANDERS VALLEY FARMS & $\begin{array}{l}\text { FLANDERS VALLEY FARMS } \\
1\end{array}$ & 404950 & 0744145 & $\mathrm{C}$ & 95.6 & 112 SFDF \\
\hline $27-1730$ & DYNEPCO, INC. & VAN HOUTEN MW-3 & 405003 & 0744127 & $\mathrm{U}$ & 25 & $112 \mathrm{SFDF}$ \\
\hline \multicolumn{8}{|c|}{ TOWNSHIP OF RANDOLPH } \\
\hline $27-1094$ & MORRIS COUNTY MUA & $\begin{array}{l}\text { MORRIS CO MUA B4 } \\
\text { LOWER }\end{array}$ & 405053 & 0743755 & $\mathrm{U}$ & 160 & 112SFDF \\
\hline $27-1095$ & MORRIS COUNTY MUA & MORRIS CO MUA B4 UPPER & 405053 & 0743755 & $\mathrm{U}$ & 38 & 112SFDF \\
\hline $27-1096$ & MORRIS COUNTY MUA & $\begin{array}{l}\text { MORRIS CO MUA B6 } \\
\text { LOWER }\end{array}$ & 405021 & 0743826 & $\mathrm{U}$ & 178 & 112SFDF \\
\hline $27-1097$ & MORRIS COUNTY MUA & MORRIS CO MUA B6 UPPER & 405021 & 0743826 & $\mathrm{U}$ & 58 & $112 \mathrm{SFDF}$ \\
\hline $27-1314$ & MORRIS COUNTY MUA & $\begin{array}{l}\text { MCMUA PW } 1 \text { ALAMA- } \\
\text { TRONG RS }\end{array}$ & 405009 & 0743834 & $P$ & 80.8 & 112SFDF \\
\hline $27-1315$ & MORRIS COUNTY MUA & MCMUA PW 2 & 405013 & 0743822 & $P$ & 70 & 112SFDF \\
\hline $27-1316$ & WESTINGHOUSE ELEVATOR CORP & WESTINGHOUSE ELEV 3 & 405112 & 0743745 & $\mathrm{~J}$ & 75 & 112SFDF \\
\hline $27-1317$ & WESTINGHOUSE ELECTRIC CORP & WESTINGHOUSE ELECT 2 & 405114 & 0743742 & $\mathrm{~J}$ & 67.6 & $112 \mathrm{SFDF}$ \\
\hline $27-1323$ & MORRIS COUNTY MUA & $\begin{array}{l}\text { MCMUA PW3 WU } 1974 \text { SUC- } \\
\text { CAS }\end{array}$ & 405027 & 0743812 & $\mathbf{P}$ & 180 & 112SFDF \\
\hline $27-1324$ & MORRIS COUNTY MUA & $\begin{array}{l}\text { MCMUA PW4 WU } 1982 \text { ALA- } \\
\text { MAT }\end{array}$ & 405052 & 0743809 & $\mathbf{P}$ & 157 & $112 \mathrm{SFDF}$ \\
\hline
\end{tabular}




\begin{tabular}{|c|c|c|c|c|c|c|c|}
\hline $\begin{array}{c}\text { New } \\
\text { Jersey } \\
\text { well } \\
\text { number }\end{array}$ & Owner & Local well identifier & $\begin{array}{l}\text { Lati- } \\
\text { tude } \\
\text { (dms) }\end{array}$ & $\begin{array}{l}\text { Longi- } \\
\text { tude } \\
\text { (dms) }\end{array}$ & $\begin{array}{c}\text { Prima- } \\
\text { ry } \\
\text { use } \\
\text { of } \\
\text { water } 1\end{array}$ & $\begin{array}{c}\text { Depth } \\
\text { of well } \\
\text { (feet) }\end{array}$ & $\begin{array}{l}\text { Aqui- } \\
\text { fer } \\
\text { code }^{2}\end{array}$ \\
\hline \multicolumn{8}{|c|}{ TOWNSHIP OF RANDOLPH--Continued } \\
\hline $27-1585$ & ARTHARS, MICHAEL & ARTHARS DOM & 405001 & 0743816 & $\mathrm{H}$ & 184 & $112 \mathrm{SFDF}$ \\
\hline $27-1586$ & NAFTAL, ROBERT & NAFTAL DOM & 405003 & 0743757 & $\mathrm{H}$ & 122 & $112 S F D F$ \\
\hline $27-1587$ & ALLAIN, RICHARD AND MARGARET & ALLAIN DOM & 405003 & 0743819 & $\mathrm{H}$ & 80 & 112SFDF \\
\hline $27-1588$ & LINDNER, MARGOT & LINDNER DOM & 405005 & 0743831 & $\mathrm{H}$ & 124 & 112 SFDF \\
\hline $27-1589$ & MORRIS COUNTY MUA & MCMUA B5-A MW & 405043 & 0743809 & $\mathrm{U}$ & 160 & $112 \mathrm{SFDF}$ \\
\hline $27-1592$ & STULL ENGRAVING COMPANY & STULL ENGRAVING PW-1 & 405103 & 0743757 & $\mathbf{N}$ & 163 & $112 S F D F$ \\
\hline $27-1593$ & $\begin{array}{l}\text { BRUVO, LILLIAN - SEAFOOD SHAK RESTAU- } \\
\text { RANT }\end{array}$ & SEAFOOD SHAK & 405141 & 0743736 & $\mathrm{C}$ & 160 & $112 S F D F$ \\
\hline $27-1707$ & MORRIS COUNTY MUA & $\begin{array}{l}\text { MCMUA B-3AB/3B ALAMA- } \\
\text { TONG }\end{array}$ & 405033 & 0743824 & $\mathrm{U}$ & 625 & 374LSVL \\
\hline \multicolumn{8}{|c|}{ TOWNSHIP OF ROCKAWAY } \\
\hline $27-0082$ & PICATINNY ARSENAL & US ARMY-PICATINNY 130 & 405624 & 0743410 & $\mathbf{P}$ & 117 & 112SFDF \\
\hline $27-0084$ & PICATINNY ARSENAL & US ARMY-PICATINNY 430A & 405644 & 0743326 & $\mathbf{N}$ & 82.0 & 112SFDF \\
\hline $27-0246$ & US ARMY - PICATINNY ARSENAL & PICATINNY 65-1 & 405620 & 0743419 & $\mathrm{U}$ & 287 & 374LSVL \\
\hline $27-0247$ & US ARMY - PICATINNY ARSENAL & PICATINNY 65-2 & 405620 & 0743419 & $\mathrm{U}$ & 206 & 112 SFDF \\
\hline $27-0249$ & US ARMY - PICATINNY ARSENAL & PICATINNY 65-4 & 405620 & 0743419 & $\mathrm{U}$ & 35.0 & 112 SFDF \\
\hline $27-0250$ & US ARMY - PICATINNY ARSENAL & PICATINNY LF 1 OBS & 405509 & 0743504 & $U$ & 345 & 374LSVL \\
\hline $27-0251$ & US ARMY - PICATINNY ARSENAL & PICATINNY LF 2 OBS & 405509 & 0743504 & $\mathrm{U}$ & 65.0 & 112 SFDF \\
\hline $27-0252$ & US ARMY - PICATINNY ARSENAL & PICATINNY LF 3 & 405509 & 0743504 & $\mathrm{U}$ & 157 & $112 S F D F$ \\
\hline $27-0267$ & PICATINNY ARSENAL & US ARMY-PICATINNY 129-OB & 405627 & 0743407 & $\mathrm{U}$ & 23.2 & $112 \mathrm{SFDF}$ \\
\hline $27-0268$ & PICATINNY ARSENAL & US ARMY-PICATINNY 151 & 405630 & 0743400 & $\mathrm{U}$ & 30.0 & $112 \mathrm{SFDF}$ \\
\hline $27-0277$ & PICATINNY ARSENAL & US ARMY-PICATINNY 176-1 & 405635 & 0743339 & $\mathrm{U}$ & 305 & 374LSVL \\
\hline $27-0278$ & US ARMY - PICATINNY ARSENAL & PICATINNY 176-SH & 405635 & 0743339 & $\mathbf{U}$ & 60.0 & $112 S F D F$ \\
\hline $27-0280$ & US ARMY - PICATINNY ARSENAL & PICATINNY H-2(D) & 405619 & 0743415 & $\mathrm{U}$ & 223 & 374LSVL \\
\hline $27-0281$ & PICATINNY ARSENAL & US ARMY-PICATINNY H-3(M) & 405619 & 0743415 & $\mathrm{U}$ & 125 & $112 S F D F$ \\
\hline $27-0282$ & PICATINNY ARSENAL & US ARMY-PICATINNY H-1(S) & 405619 & 0743415 & $\mathrm{U}$ & 25.0 & 112 SFDF \\
\hline
\end{tabular}




\begin{tabular}{|c|c|c|c|c|c|c|c|}
\hline $\begin{array}{c}\text { New } \\
\text { Jersey } \\
\text { well } \\
\text { number }\end{array}$ & Owner & Local well identifier & $\begin{array}{l}\text { Lati- } \\
\text { tude } \\
\text { (dms) }\end{array}$ & $\begin{array}{l}\text { Longi- } \\
\text { tude } \\
(\mathrm{dms})\end{array}$ & $\begin{array}{c}\text { Prima- } \\
\text { ry } \\
\text { use } \\
\text { of } \\
\text { water }^{1}\end{array}$ & $\begin{array}{c}\text { Depth } \\
\text { of well } \\
\text { (feet) }\end{array}$ & $\begin{array}{l}\text { Aqui- } \\
\text { fer } \\
\text { code }^{2}\end{array}$ \\
\hline \multicolumn{8}{|c|}{ TOWNSHIP OF ROCKAWAY--Continued } \\
\hline $27-0968$ & PICATINNY ARSENAL & US ARMY-PICATINNY 10-3A & 405630 & 0743416 & $\mathrm{U}$ & 264 & 374LSVL \\
\hline $27-0970$ & PICATINNY ARSENAL & US ARMY-PICATINNY 39-1 & 405603 & 0743418 & $\mathrm{U}$ & 205 & $112 \mathrm{SFDF}$ \\
\hline $27-0971$ & PICATINNY ARSENAL & US ARMY-PICATINNY 39-2 & 405603 & 0743418 & $\mathrm{U}$ & 101 & $112 \mathrm{SFDF}$ \\
\hline $27-0972$ & PICATINNY ARSENAL & US ARMY-PICATINNY 95-1 & 405608 & 0743431 & $\mathrm{U}$ & 119 & $112 \mathrm{SFDF}$ \\
\hline $27-0973$ & PICATINNY ARSENAL & US ARMY-PICATINNY 95-2 & 405608 & 0743431 & $\mathrm{U}$ & 200 & $112 \mathrm{SFDF}$ \\
\hline $27-1127$ & US ARMY - PICATINNY ARSENAL & PICATINNY SB1-1 OBS & 405458 & 0743455 & $\mathbf{U}$ & 93 & $400 \mathrm{PCMB}$ \\
\hline $27-1128$ & US ARMY - PICATINNY ARSENAL & PICATINNY SB1-2 OBS & 405458 & 0743455 & $\mathrm{U}$ & 18 & $112 \mathrm{SFDF}$ \\
\hline $27-1129$ & US ARMY - PICATINNY ARSENAL & PICATINNY SB1-3 OBS & 405458 & 0743455 & $\mathrm{U}$ & 34 & $112 \mathrm{SFDF}$ \\
\hline $27-1130$ & US ARMY - PICATINNY ARSENAL & PICATINNY SB2-1 OBS & 405509 & 0743509 & $U$ & 168 & $112 \mathrm{SFDF}$ \\
\hline $27-1131$ & US ARMY - PICATINNY ARSENAL & PICATINNY SB2-2 OBS & 405509 & 0743509 & $\mathrm{U}$ & 35 & 112 SFDF \\
\hline $27-1132$ & US ARMY - PICATINNY ARSENAL & PICATINNY SB3-1 OBS & 405517 & 0743515 & $\mathrm{U}$ & 360 & 374LSVL \\
\hline $27-1133$ & US ARMY - PICATINNY ARSENAL & PICATINNY SB2-3 OBS & 405509 & 0743509 & $\mathrm{U}$ & 253 & 374LSVL \\
\hline $27-1134$ & US ARMY - PICATINNY ARSENAL & PICATINNY SB3-2 OBS & 405517 & 0743515 & $\mathrm{U}$ & 180 & $112 \mathrm{SFDF}$ \\
\hline $27-1135$ & US ARMY - PICATINNY ARSENAL & PICATINNY SB3-3 OBS & 405517 & 0743515 & $\mathrm{U}$ & 31.0 & $112 \mathrm{SFDF}$ \\
\hline $27-1594$ & HIGHLAND OF MORRIS & $\begin{array}{l}\text { HIGHLAND OF MORRIS } \\
\text { DOM }\end{array}$ & 405503 & 0743526 & $\mathrm{H}$ & 80 & $112 \mathrm{SFDF}$ \\
\hline $27-1595$ & DEMAYO, LOUIS AND MARION & DEMAYO DOM & 405517 & 0743518 & $\mathrm{H}$ & 154 & $112 \mathrm{SFDF}$ \\
\hline $27-1704$ & CASEY, JULIA & CASEY HAND DUG DOM 1 & 405418 & 0743537 & $\mathbf{H}$ & 30 & $112 \mathrm{SFDF}$ \\
\hline \multicolumn{8}{|c|}{ TOWNSHIP OF ROXBURY } \\
\hline $27-0908$ & ZALASKY, MINNIE & ZALASKY & 405341 & 0743642 & $\mathrm{H}$ & 135 & $112 \mathrm{SFDF}$ \\
\hline $27-0921$ & STATE OF NJ - DEP & TW 10 & 405417 & 0743645 & $\mathrm{U}$ & 87.9 & $112 \mathrm{SFDF}$ \\
\hline $27-0976$ & MILLER, LILIAN & PALMER 1 & 405401 & 0743609 & $\mathrm{H}$ & 60.0 & $112 \mathrm{SFDF}$ \\
\hline $27-0977$ & ROXBURY TWP WATER DEPT & EVERGREEN ACRES 1 & 405503 & 0743628 & $\mathrm{P}$ & 208 & $112 \mathrm{SFDF}$ \\
\hline $27-1083$ & MORRIS COUNTY MUA & MCMUA TEST WELL 1 OBS & 405005 & 0744101 & $\mathbf{U}$ & 250 & 374LSVL \\
\hline $27-1087$ & HERCULES INC & HERCULES $1-1940$ & 405310 & 0743704 & $\mathrm{~N}$ & 105 & $112 \mathrm{SFDF}$ \\
\hline $27-1088$ & KENVIL NEWCRETE CO & KENVIL NEWCRETE 2 & 405313 & 0743656 & $\mathbf{N}$ & 160 & $112 \mathrm{SFDF}$ \\
\hline $27-1098$ & BOHS, DIANNE & BOHS 1 & 405139 & 0744027 & $\mathrm{H}$ & 105 & $112 \mathrm{SFDF}$ \\
\hline $27-1099$ & SMITH, JAMES J & JAMES SMITH 1 & 405205 & 0743809 & $\mathrm{H}$ & 248 & 374LSVL \\
\hline $27-1100$ & ROXBURY WATER COMPANY & ROXBURY WATER CO 1 & 405108 & 0743836 & $\mathrm{P}$ & 52 & $112 S F D F$ \\
\hline $27-1103$ & ROXBURY WATER DEPARTMENT & ROXBURY TWP WD 10 & 405228 & 0744014 & $\mathrm{P}$ & 170 & $400 \mathrm{PCMB}$ \\
\hline $27-1104$ & ROXBURY WATER DEPARTMENT & ROXBURY TWP WD 11 & 405228 & 0744013 & $\mathbf{P}$ & 550 & 400PCMB \\
\hline $27-1123$ & US GEOLOGICAL SURVEY & KENVIL NEWCRETE 1 OBS & 405330 & 0743638 & $\mathrm{U}$ & 307 & 374LSVL \\
\hline $27-1124$ & US GEOLOGICAL SURVEY & KENVIL NEWCRETE 2 OBS & 405330 & 0743638 & $\mathrm{U}$ & 175 & $112 \mathrm{SFDF}$ \\
\hline $27-1145$ & ROXBURY WATER CO & ROXBURY 5 & 405006 & 0744020 & $\mathrm{U}$ & 345 & $400 \mathrm{PCMB}$ \\
\hline
\end{tabular}




\begin{tabular}{|c|c|c|c|c|c|c|c|}
\hline $\begin{array}{c}\text { New } \\
\text { Jersey } \\
\text { well } \\
\text { number }\end{array}$ & Owner & Local well identifier & $\begin{array}{l}\text { Lati- } \\
\text { tude } \\
(\mathrm{dms})\end{array}$ & $\begin{array}{l}\text { Longi- } \\
\text { tude } \\
\text { (dms) }\end{array}$ & $\begin{array}{c}\text { Prima- } \\
\text { ry } \\
\text { use } \\
\text { of } \\
\text { water }\end{array}$ & $\begin{array}{l}\text { Depth } \\
\text { of well } \\
\text { (feet) }\end{array}$ & $\begin{array}{l}\text { Aqui- } \\
\text { fer } \\
\text { code }^{2}\end{array}$ \\
\hline \multicolumn{8}{|c|}{ TOWNSHIP OF ROXBURY--Continued } \\
\hline $27-1170$ & ARICO, DIANNE & ARICO DOM & 405054 & 0744109 & $\mathrm{H}$ & 222 & 350GRPD \\
\hline $27-1172$ & DAWSON, CHUCK & DAWSON DOM & 405104 & 0744110 & $\mathrm{H}$ & 100 & $112 \mathrm{SFDF}$ \\
\hline $27-1173$ & ROXBURY WATER COMPANY & RWC PW7-PLEASANT VILL 1 & 405108 & 0744110 & $\mathbf{P}$ & 175 & 374LSVL \\
\hline $27-1174$ & ALTAR, ANGELA & ROKA DOM & 405122 & 0743905 & H & 125 & 350GRPD \\
\hline $27-1175$ & NORTH JERSEY DEVELOPMENT & NORTH JERSEY DEV COM & 405137 & 0743750 & $\mathrm{C}$ & 225 & 374LSVL \\
\hline $27-1176$ & NIXON, HARRY AND MARY & NIXON DOM & 405214 & 0743819 & $\mathrm{H}$ & 106 & $112 \mathrm{SFDF}$ \\
\hline $27-1177$ & ROXBURY WATER COMPANY & RWC PW6-KENTWOOD RD & 405235 & 0743818 & $P$ & 55 & $112 \mathrm{SFDF}$ \\
\hline $27-1179$ & LOZAUSKAS, PEGGY & LOZAUSKAS DOM & 405237 & 0743942 & $\mathbf{H}$ & 445 & $400 \mathrm{PCMB}$ \\
\hline $27-1180$ & ANTANELIS, JOHN & ANTANELIS DOM & 405240 & 0743915 & $\mathrm{H}$ & 61 & $112 \mathrm{SFDF}$ \\
\hline $27-1181$ & BEAGLE, EDWARD AND FLORENCE & BEAGLE DOM & 405245 & 0743921 & $\mathrm{H}$ & 141 & 112SFDF \\
\hline $27-1182$ & PETILLO ENTERPRISES INC & PETILLO ENTERPRISE COM & 405305 & 0743659 & $\mathbf{C}$ & 225 & 112 SFDF \\
\hline $27-1183$ & US GEOLOGICAL SURVEY & KENVIL NEWCRETE 7 OBS & 405330 & 0743638 & $\mathrm{U}$ & 63 & $112 S F D F$ \\
\hline $27-1184$ & HERRS MOTOR EXPRESS & $\begin{array}{l}\text { HERRS MOTOR EXPRESS } \\
\text { COM }\end{array}$ & 405408 & 0743637 & C & 50 & 112 SFDF \\
\hline $27-1185$ & ARENDASKY, JMM & ARENDASKY 1 & 405431 & 0743626 & $\mathrm{H}$ & 51 & $112 S F D F$ \\
\hline $27-1186$ & CHOPRA, RAJINDAR PAUL & CHOPRA DOM & 405309 & 0743727 & H & 225 & 350GRPD \\
\hline $27-1187$ & HOLMES, HAROLD & HOLMES DOM & 405443 & 0743638 & $\mathrm{H}$ & 188 & $112 \mathrm{SFDF}$ \\
\hline $27-1188$ & $\begin{array}{l}\text { LOWER BERKSHIRE VALLEY UNITED METH- } \\
\text { ODIST CH }\end{array}$ & $\begin{array}{l}\text { L BERKSH V METH } \\
\text { CHURCH } 1\end{array}$ & 405444 & 0743636 & $T$ & 55 & $112 \mathrm{SFDF}$ \\
\hline $27-1191$ & STATE OF NJ & ROXBURY 1 OBS & 405123 & 0743757 & $\mathrm{U}$ & 154 & $112 S F D F$ \\
\hline $27-1308$ & ROXBURY WATER COMPANY & $\begin{array}{l}\text { RWC AIRPORT TW REGER } \\
\text { OBS }\end{array}$ & 405010 & 0744102 & $\mathrm{U}$ & 245 & 374LSVL \\
\hline $27-1322$ & ROXBURY WATER COMPANY & RWC 1AT & 405107 & 0743835 & $\mathrm{U}$ & 607 & 374LSVL \\
\hline $27-1596$ & NEUMANN, HENRY & NEUMANN DOM & 405020 & 0743944 & $\mathrm{H}$ & 298 & 400РCMB \\
\hline $27-1597$ & STATE OF NJ - DEP & $\begin{array}{l}\text { NJDEP KENNEDY SCHOOL } \\
\text { MW }\end{array}$ & 405047 & 0743929 & $\mathrm{U}$ & 345 & 374LSVL \\
\hline $27-1598$ & WESTON, JOHN AND SHERMAN, JUDITH & GLORY HOMES BURIED & 405049 & 0744047 & $\mathrm{H}$ & 96 & 374LSVL \\
\hline $27-1599$ & LEVY, CARY AND ELLEN & LEVY DOM & 405103 & 0743917 & $\mathrm{H}$ & 110 & $112 \mathrm{SFDF}$ \\
\hline $27-1601$ & PEDYNOWSKI, HENRY AND JANICE & 27-1600 DEEPENED & 405104 & 0744019 & $\mathbf{H}$ & 348 & $350 \mathrm{GRPD}$ \\
\hline $27-1602$ & SIVERSTEN, ANNY & SIVERSTEN DOM & 405108 & 0743918 & $\mathbf{H}$ & 130 & $112 S F D F$ \\
\hline $27-1603$ & KOWASKI, JOE & JC BUILDERS DOM & 405111 & 0744002 & $\mathrm{H}$ & 248 & 350GRPD \\
\hline $27-1604$ & SSC HOLDING COMPANY & SPORT \& SWIM CLUB & 405115 & 0744056 & $\mathbf{R}$ & 62 & $112 \mathrm{SFDF}$ \\
\hline $27-1605$ & NALLEN, JM AND LORI & NALLEN/DYRNESS 7239 & 405119 & 0743906 & $\mathrm{H}$ & 146 & $112 \mathrm{SFDF}$ \\
\hline $27-1606$ & BENNETT, PAUL AND ROSEANN & BENNETT DOM & 405120 & 0744013 & $\mathrm{H}$ & 60 & $112 \mathrm{SFDF}$ \\
\hline $27-1607$ & PELLEGRINO, GERARD AND TAMMY & PELLEGRINO BURIED & 405121 & 0743907 & $\mathrm{H}$ & 243 & $112 \mathrm{SFDF}$ \\
\hline $27-1608$ & VASSALLO, ANTONINO & VASSALLO DOM & 405124 & 0744027 & $\mathbf{H}$ & 123 & 350GRPD \\
\hline $27-1609$ & DAVENPORT, ROBERT & DAVENPORT DOM & 405125 & 0743816 & $\mathbf{H}$ & 152 & 112SFDF \\
\hline $27-1610$ & MOORE, JULIA & MOORE DOM & 405127 & 0744027 & H & 200 & $112 \mathrm{SFDF}$ \\
\hline $27-1611$ & VITCUSKY, THEODORE AND PHYLLIS & VITCUSKY DOM & 405140 & 0744024 & $\mathbf{H}$ & 98 & $112 \mathrm{SFDF}$ \\
\hline
\end{tabular}




\begin{tabular}{|c|c|c|c|c|c|c|c|}
\hline $\begin{array}{c}\text { New } \\
\text { Jersey } \\
\text { well } \\
\text { number }\end{array}$ & Owner & Local well identifier & $\begin{array}{l}\text { Lati- } \\
\text { tude } \\
(\mathrm{dms})\end{array}$ & $\begin{array}{l}\text { Longi- } \\
\text { tude } \\
(\mathrm{dms})\end{array}$ & $\begin{array}{c}\text { Prima- } \\
\text { ry } \\
\text { use } \\
\text { of } \\
\text { water }^{1}\end{array}$ & $\begin{array}{c}\text { Depth } \\
\text { of well } \\
\text { (feet) }\end{array}$ & $\begin{array}{l}\text { Aqui- } \\
\text { fer } \\
\text { code }^{2}\end{array}$ \\
\hline \multicolumn{8}{|c|}{ TOWNSHIP OF ROXBURY--Continued } \\
\hline $27-1612$ & DUNN, DANIEL J - DUNN FINANCIAL REVIEW & DUNN DOM & 405143 & 0743749 & $\mathrm{H}$ & 208 & 112SFDF \\
\hline $27-1613$ & SPARTAN OIL & SPARTAN OIL D-4 MW & 405146 & 0743802 & D & 25 & 112 SFDF \\
\hline $27-1614$ & ROSENBLATT, BOB & ROSENBLATT DOM & 405146 & 0743816 & $\mathrm{H}$ & 200 & 112 SFDF \\
\hline $27-1615$ & HILL, JAMES AND BERNADETTE & HILL DOM & 405148 & 0743827 & $\mathbf{H}$ & 325 & 374LSVL \\
\hline $27-1616$ & MOORE, BETTY & MOORE DOM & 405150 & 0743830 & $\mathbf{H}$ & 109 & 112SFDF \\
\hline $27-1617$ & BROOMERKEL, JOHN & BROOMERKEL DOM & 405151 & 0743834 & $\mathbf{H}$ & 125 & 350GRPD \\
\hline $27-1618$ & BYTZ, MYRON & BYTZ COM & 405156 & 0743816 & $\mathbf{C}$ & 347 & $112 \mathrm{SFDF}$ \\
\hline $27-1619$ & MILSOM, GARY & MILSOM DOM & 405204 & 0743737 & $\mathbf{H}$ & 180 & $112 \mathrm{SFDF}$ \\
\hline $27-1620$ & WALDRON, WILLIAM & WALDRON BURIED & 405205 & 0743801 & $\mathbf{H}$ & 160 & $112 \mathrm{SFDF}$ \\
\hline $27-1621$ & ROXBURY TWP PUBLIC LIBRARY & ROXBURY LIBRARY BURIED & 405209 & 0743819 & $\mathrm{~T}$ & 70 & 112 SFDF \\
\hline $27-1622$ & OBRIEN, FREDERICK & OBRIEN BURIED & 405213 & 0743756 & $\mathbf{H}$ & 195 & $112 \mathrm{SFDF}$ \\
\hline $27-1623$ & ROXBURY TWP & EMMANS RD PARK 1 & 405220 & 0743942 & $\mathbf{R}$ & 131 & $112 \mathrm{SFDF}$ \\
\hline $27-1624$ & MICIAK, LARRY AND JAN & SENECA HILLS MICIAK & 405222 & 0743944 & $\mathbf{H}$ & 100 & 400PCMB \\
\hline $27-1625$ & ST THERESA SCHOOL & ST THERESA SCHOOL 1 & 405225 & 0743832 & $\mathrm{~T}$ & 223 & 374LSVL \\
\hline $27-1626$ & COLANANNI, GREG AND LISA & SENECA HILLS COLANANNI & 405225 & 0743942 & $\mathbf{H}$ & 54 & 377HRDS \\
\hline $27-1627$ & CHUN, DR. & BOSSEN BURIED & 405228 & 0743711 & $\mathbf{U}$ & 175 & $112 \mathrm{SFDF}$ \\
\hline $27-1628$ & WALSH, THOMAS AND MARGARET & WALSH DOM & 405237 & 0743756 & $\mathbf{H}$ & 152 & $112 \mathrm{SFDF}$ \\
\hline $27-1629$ & SMITH, KATHLEEN & NICKERSON 1 & 405239 & 0743709 & $\mathbf{H}$ & 220 & 112 SFDF \\
\hline $27-1630$ & CLASSIC ASSOCIATES INC & CLASSIC WAFFLE HUT & 405242 & 0743843 & $\mathbf{C}$ & 158 & $112 \mathrm{SFDF}$ \\
\hline $27-1631$ & SILCOX, LINDA S & SILCOX DOM & 405243 & 0743802 & $\mathbf{H}$ & 223 & 350GRPD \\
\hline $27-1632$ & LEWIS, GEORGE JR & LEWIS ELECTRONICS & 405245 & 0743722 & $\mathbf{H}$ & 195 & 112SFDF \\
\hline $27-1633$ & MORAN, JOHN J & MORAN DOM & 405246 & 0743658 & $\mathbf{H}$ & 160 & 112SFDF \\
\hline $27-1634$ & RETTINO, JOE - DIAMOND GLASS \& MIRROR & BEVACQUA & 405247 & 0743705 & $\mathbf{C}$ & 200 & 112SFDF \\
\hline $27-1635$ & LIST, ED & LIST DOM & 405248 & 0743724 & $\mathrm{H}$ & 207 & 112 SFDF \\
\hline $27-1636$ & ARCHER, PAUL & ARCHER DOM & 405249 & 0743733 & $\mathrm{H}$ & 250 & 350GRPD \\
\hline $27-1637$ & MILLER, LAUREN AND GORDON & DENWOOD HOMES INC DOM & 405251 & 0743700 & $\mathbf{H}$ & 166 & $112 S F D F$ \\
\hline $27-1638$ & CATER, DENNIS AND LISA & PARKS DOM & 405252 & 0743728 & $\mathbf{H}$ & 215 & $112 \mathrm{SFDF}$ \\
\hline $27-1639$ & GUERRERO, JOHN AND PHYLLIS & GUERRERO BURIED & 405255 & 0743710 & $\mathrm{H}$ & 231 & $112 S F D F$ \\
\hline $27-1640$ & KOWZUN, GEORGE P & KOWZUN DOM & 405257 & 0743742 & $\mathbf{H}$ & 75 & 350GRPD \\
\hline $27-1641$ & HERCULES INC & HERCULES MW 21 & 405258 & 0743823 & $\mathrm{U}$ & 20 & $112 \mathrm{SFDF}$ \\
\hline $27-1642$ & TROIANELLO, ALFONSO & GOMEZ DOM & 405259 & 0743705 & $\mathbf{H}$ & 228 & $112 S F D F$ \\
\hline $27-1643$ & VALDES, ELISIO & CHOPPA DOM & 405310 & 0743726 & $\mathrm{H}$ & 150 & 350GRPD \\
\hline $27-1644$ & HERCULES INC & HERCULES MW 25 & 405314 & 0743809 & $\mathbf{U}$ & 15 & 112 SFDF \\
\hline $27-1645$ & LAKELAND ANIMAL HAVEN & $\begin{array}{l}\text { LAKELAND ANIMAL BUR- } \\
\text { IED }\end{array}$ & 405315 & 0743634 & $\mathbf{H}$ & 140 & 112 SFDF \\
\hline $27-1646$ & PEER, CHARLES & NAIM BURIED & 405316 & 0743636 & $\mathbf{H}$ & 180 & 112 SFDF \\
\hline
\end{tabular}




\begin{tabular}{|c|c|c|c|c|c|c|c|}
\hline $\begin{array}{c}\text { New } \\
\text { Jersey } \\
\text { well } \\
\text { number }\end{array}$ & Owner & Local well identifier & $\begin{array}{l}\text { Lati- } \\
\text { tude } \\
\text { (dms) }\end{array}$ & $\begin{array}{l}\text { Longi- } \\
\text { tude } \\
\text { (dms) }\end{array}$ & $\begin{array}{c}\text { Prima- } \\
\text { ry } \\
\text { use } \\
\text { of } \\
\text { water }^{1}\end{array}$ & $\begin{array}{l}\text { Depth } \\
\text { of well } \\
\text { (feet) }\end{array}$ & $\begin{array}{c}\text { Aqui- } \\
\text { fer } \\
\text { code }^{2}\end{array}$ \\
\hline
\end{tabular}

TOWNSHIP OF ROXBURY--Continued

\begin{tabular}{|c|c|c|c|c|c|c|c|}
\hline $27-1647$ & TURBECK, ANDREW J & TURBECK DOM & 405317 & 0743650 & $\mathrm{H}$ & 82 & 112SFDF \\
\hline $27-1648$ & HERCULES INC & HERCULES MW 18 & 405317 & 0743744 & $\mathrm{U}$ & 16 & 112 SFDF \\
\hline $27-1649$ & DONOFRIO, ANTHONY & DONOFRIO DOM & 405321 & 0743647 & $\mathrm{H}$ & 118 & 112SFDF \\
\hline $27-1651$ & CONCRETE INDUSTRIES & CONCRETE IND 1963 & 405325 & 0743639 & $\mathbf{N}$ & 380 & 374LSVL \\
\hline $27-1652$ & HERCULES INC & HERCULES MW 17 & 405328 & 0743759 & $\mathrm{U}$ & 18 & $112 \mathrm{SFDF}$ \\
\hline $27-1654$ & HERCULES INC & HERCULES MW 26 & 405334 & 0743729 & $\mathrm{U}$ & 23 & $112 \mathrm{SFDF}$ \\
\hline $27-1655$ & HERCULES INC & HERCULES MW 12 & 405349 & 0743734 & $\mathrm{U}$ & I3 & $112 \mathrm{SFDF}$ \\
\hline $27-1656$ & MILNE, ROBERT & COLE DOM & 405353 & 0743633 & $\mathrm{H}$ & 115 & 112 SFDF \\
\hline $27-1657$ & HOOK, RODNEY & RONCO LOT 24.7 & 405355 & 0743632 & $H$ & 103 & $112 \mathrm{SFDF}$ \\
\hline $27-1661$ & DOWNEY J AND PAT & FILIPSKI DOM & 405433 & 0743642 & $\mathrm{H}$ & 51 & 112 SFDF \\
\hline $27-1662$ & MORGAN, RICHARD & MORGAN DOM & 405433 & 0743653 & $\mathrm{H}$ & 80 & 112SFDF \\
\hline $27-1663$ & DAY, FRANCIS & HILBERT DOM & 405434 & 0743623 & $\mathrm{H}$ & 103 & $112 \mathrm{SFDF}$ \\
\hline $27-1664$ & SEEGER, WILLIAM & SEEGER DOM & 405435 & 0743640 & $\mathrm{H}$ & 61 & 112 SFDF \\
\hline $27-1665$ & SCHMIDT & FARLEY DOM & 405437 & 0743653 & $\mathrm{H}$ & 80 & $112 \mathrm{SFDF}$ \\
\hline $27-1666$ & MACARTHUR, RICHARD AND KAREN & FAUST DOM & 405439 & 0743622 & $\mathrm{H}$ & 123 & $112 \mathrm{SFDF}$ \\
\hline $27-1667$ & IVERSON, NORMAN & VANDERHOOF DOM 2074 & 405441 & 0743639 & $\mathrm{H}$ & 199 & $112 \mathrm{SFDF}$ \\
\hline $27-1712$ & $\begin{array}{l}\text { WILLIAMS, MADELINE AND COVERT, MADE- } \\
\text { LINE }\end{array}$ & WILLIAMS I DOM & 405247 & 0743709 & $\mathbf{H}$ & 220 & $112 \mathrm{SFDF}$ \\
\hline $27-1713$ & HERCULES INC & HERCULES 2-1942 & 405310 & 0743707 & $\mathbf{N}$ & 111 & 112 SFDF \\
\hline $27-1728$ & MORRIS COUNTY MUA & FLANDERS GOLF PW & 405005 & 0744101 & $\mathbf{P}$ & 245 & 374LSVL \\
\hline $27-1733$ & ROXBURY WATER COMPANY & RWC IA PW & 405107 & 0743835 & $\mathbf{P}$ & 700 & 374LSVL \\
\hline
\end{tabular}

TOWNSHIP OF WASHINGTON

27-1085 WASHINGTON TOWNSHIP MUA

27-1105 MCCORMACK, JOHN AND IRENE

27-1106 W MORRIS REG HS DIST BRD OF ED

27-1107 PACZKOWSKI, JOHN

27-1108 NAUGHRIGHT, JOHN AND VIRGINIA
WASHINGTON TWP TW OBS 404705

MCCORMACK 1

W MORRIS CENTRAL HS I

PACZKOWSKI 1

NAUGHRIGHT 1

$\begin{array}{llll}0744638 & \text { U } & 290 & 374 L S V L \\ 0744456 & \text { H } & 123 & 374 L S V L \\ 0744338 & \text { I } & 450 & 374 L S V L \\ 0744452 & \text { H } & 67 & 374 L S V L \\ 0744446 & \text { H } & 60 & 374 \text { LSVL }\end{array}$




\begin{tabular}{|c|c|c|c|c|c|c|c|}
\hline $\begin{array}{c}\text { New } \\
\text { Jersey } \\
\text { well } \\
\text { number }\end{array}$ & Owner & Local well identifier & $\begin{array}{l}\text { Lati- } \\
\text { tude } \\
\text { (dms) }\end{array}$ & $\begin{array}{l}\text { Longi- } \\
\text { tude } \\
(\mathrm{dms})\end{array}$ & $\begin{array}{c}\text { Prima- } \\
\text { ry } \\
\text { use } \\
\text { of } \\
\text { water }^{1}\end{array}$ & $\begin{array}{c}\text { Depth } \\
\text { of well } \\
\text { (feet) }\end{array}$ & $\begin{array}{l}\text { Aqui- } \\
\text { fer } \\
\text { code }^{2}\end{array}$ \\
\hline \multicolumn{8}{|c|}{ TOWNSHIP OF WASHINGTON--Continued } \\
\hline $27-1117$ & DREW UNIVERSITY & DREW UNIV 1 - VMG 7226 & 404702 & 0744538 & $\mathrm{H}$ & 135 & 374LSVL \\
\hline $27-1118$ & LYNCH, LISA & LYNCH 1 & 404811 & 0744515 & $\mathbf{H}$ & 200 & 374LSVL \\
\hline $27-1119$ & LONG VALLEY PRESBYTERIAN CHURCH & LONG VALLEY PRESB CH & 404725 & 074452 I & $\mathrm{T}$ & 280 & 374LSVL \\
\hline $27-1120$ & SMITH, EARL AND PHYLLIS & SMITH DOM & 404813 & 0744617 & $\mathbf{H}$ & 123 & 400PCMB \\
\hline $27-1121$ & BEAM, THEODORE & BEAM 1 & 404546 & 0744924 & $\mathbf{H}$ & 110 & $112 \mathrm{SFDF}$ \\
\hline $27-1122$ & VANCE, FRED & VANCE 1 & 404548 & 0744919 & $\mathbf{H}$ & 218 & 374LSVL \\
\hline $27-1154$ & GERNON, KINGSLEY AND DOROTHY & GERNON DOM & 404508 & 0744802 & $\mathbf{H}$ & 97 & 400PCMB \\
\hline $27-1156$ & ODOWD, JOAN & ODOWD DOM & 404624 & 0744803 & $\mathbf{H}$ & 175 & 374LSVL \\
\hline $27-1157$ & RYAN, JACK & RYAN DOM WELL & 404625 & 0744744 & $\mathbf{H}$ & 125 & 374LSVL \\
\hline $27-1160$ & WELSH FARMS INC & WELSH FARMS 1 & 404717 & 0744638 & $\mathrm{H}$ & 223 & 374LSVL \\
\hline $27-1161$ & HIGGINS, CARL & HIGGINS DOM & 404751 & 0744556 & $\mathbf{H}$ & 298 & 400PCMB \\
\hline $27-1162$ & GOETZ, GARY & GOETZ DOM & 404802 & 0744501 & $\mathbf{H}$ & 230 & 400PCMB \\
\hline $27-1163$ & COLLING, HENRY & COLLING DOM & 404805 & 0744516 & $\mathrm{H}$ & 105 & 374LSVL \\
\hline $27-1165$ & EBERBACH, WILLIAM & EBERBACH 1 & 404823 & 0744344 & $\mathbf{H}$ & 61 & 112SFDF \\
\hline $27-1166$ & ZAIKOWSKI, CAROL & ZAIKOWSKI DOM & 404823 & 0744420 & $\mathrm{H}$ & 90 & 374LSVL \\
\hline $27-1167$ & REDER, JEFF & REDER DOM & 404848 & 0744342 & $\mathrm{H}$ & 65 & 112SFDF \\
\hline $27-1302$ & STATE OF NJ - GEOLOGICAL SURVEY & JENKINSON FARM 1 OBS & 404452 & 0744931 & $\mathrm{U}$ & 597 & 374LSVL \\
\hline $27-1303$ & STATE OF NJ - GEOLOGICAL SURVEY & $\begin{array}{l}\text { DREW UNIVERSITY FARM } \\
\text { OBS }\end{array}$ & 404712 & 0744547 & $\mathrm{U}$ & 118 & 374LSVL \\
\hline $27-1670$ & CAVISTAN, J P - MIDATLANTIC MFG CO & MIDATLANTIC DOM & 404433 & 0744902 & $\mathbf{H}$ & 205 & 374LSVL \\
\hline $27-1671$ & SCHIRMACHER, PAUL & SCHIRMACHER DOM 1 & 404435 & 0744906 & $\mathbf{H}$ & 130 & 374LSVL \\
\hline $27-1672$ & FRIEDEMANN, JOHN & FRIEDEMANN DOM & 404439 & 0744922 & $\mathbf{H}$ & 105 & $112 \mathrm{SFDF}$ \\
\hline $27-1673$ & STATE OF NJ - DEP & NJDEP JENKINSON & 404446 & 0744918 & $\mathrm{U}$ & 125 & 374LSVL \\
\hline $27-1674$ & GREENHALGH, RAYMOND & GREENHALGH DOM & 404510 & 0744811 & $\mathrm{H}$ & 122 & 112SFDF \\
\hline $27-1675$ & MONAHAN, BERNARD & MONAHAN DOM & 404525 & 0744829 & $\mathbf{H}$ & 173 & 374LSVL \\
\hline $27-1676$ & AVILA, PRIMA & AVILA DOM & 404527 & 0744758 & $\mathbf{H}$ & 348 & 374LSVL \\
\hline $27-1677$ & FALKENSTERN, NORMAN & FALKENSTERN DOM & 404530 & 0744814 & $\mathrm{H}$ & 173 & 374LSVL \\
\hline $27-1678$ & MANCINI, THOMAS & MANCINI DOM & 404534 & 0744920 & $\mathrm{H}$ & 63 & 374LSVL \\
\hline $27-1679$ & GARDINER, HENRY AND JODY & GARDINER DOM & 404536 & 0744918 & $\mathrm{H}$ & 60 & $112 \mathrm{SFDF}$ \\
\hline $27-1680$ & MESLER, HAROLD & MESLER DOM & 404538 & 0744917 & $\mathbf{H}$ & 115 & 374LSVL \\
\hline $27-1681$ & LAHMAN & DOM LOT 37-1 & 404548 & 0744829 & $\mathrm{H}$ & 198 & 374LSVL \\
\hline $27-1682$ & GORGIAS & DOM LOT 37-15 & 404549 & 0744818 & $\mathrm{H}$ & 173 & 374LSVL \\
\hline $27-1683$ & FANIA, ANTHONY & DOM LOT $37-16$ & 404550 & 0744820 & $\mathbf{H}$ & 148 & 374LSVL \\
\hline $27-1684$ & RISPOLI, GINA & DOM LOT 37-18 & 404550 & 0744827 & $\mathrm{H}$ & 140 & 374LSVL \\
\hline $27-1685$ & ALEXANDER & DOM LOT 37-14 & 404551 & 0744814 & $\mathrm{H}$ & 173 & 374LSVL \\
\hline $27-1686$ & SCOTT, JANET & DOM LOT $37-17$ & 404551 & 0744825 & $\mathrm{H}$ & 173 & 374LSVL \\
\hline
\end{tabular}




\begin{tabular}{|c|c|c|c|c|c|c|c|}
\hline $\begin{array}{c}\text { New } \\
\text { Jersey } \\
\text { well } \\
\text { number }\end{array}$ & Owner & Local well identifier & $\begin{array}{c}\text { Lati- } \\
\text { tude } \\
\text { (dms) }\end{array}$ & $\begin{array}{l}\text { Longi- } \\
\text { tude } \\
\text { (dms) }\end{array}$ & $\begin{array}{c}\text { Prima- } \\
\text { ry } \\
\text { use } \\
\text { of } \\
\text { water }^{1}\end{array}$ & $\begin{array}{c}\text { Depth } \\
\text { of wel] } \\
\text { (feet) }\end{array}$ & $\begin{array}{l}\text { Aqui- } \\
\text { fer } \\
\text { code }^{2}\end{array}$ \\
\hline \multicolumn{8}{|c|}{ TOWNSHIP OF WASHINGTON--Continued } \\
\hline $27-1687$ & ZAMBOR & DOM LOT 37-8 & 404553 & 0744824 & $\mathbf{H}$ & 198 & 374LSVL \\
\hline $27-1688$ & IPPOLITI & DOM LOT 37-13 & 404556 & 0744822 & $\mathbf{H}$ & 173 & 374LSVL \\
\hline $27-1689$ & TODD & DOM LOT 37-11 & 404558 & 0744823 & $\mathbf{H}$ & 198 & 374LSVL \\
\hline $27-1690$ & $\begin{array}{l}\text { WASHINGTON TOWNSHIP - BOARD OF EDU- } \\
\text { CATION }\end{array}$ & OLD FARMERS RD SCHOOL 1 & 404611 & 0744553 & $\mathbf{T}$ & 300 & 400PCMB \\
\hline $27-1691$ & JONES, MRS. & JONES DOM & 404612 & 0744804 & $\mathbf{H}$ & 125 & 374LSVL \\
\hline $27-1692$ & $\begin{array}{l}\text { WASHINGTON TOWNSHIP - BOARD OF EDU- } \\
\text { CATION }\end{array}$ & LONG VALLEY MIDDLE SCH & 404659 & 0744700 & $\mathbf{T}$ & 214 & 374LSVL \\
\hline $27-1693$ & VALLEY VIEW CHAPEL & VALLEY VIEW CHAPEL 1 & 404701 & 0744533 & $T$ & 198 & 374LSVL \\
\hline $27-1694$ & MOHAWK OIL COMPANY & MOHAWK OIL W-10 MW & 404704 & 0744630 & $U$ & 23 & 374LSVL \\
\hline $27-1695$ & KELLER, WILLIAM & KELLER DOM & 404719 & 0744424 & H & 106 & 374LSVL \\
\hline $27-1696$ & RAUSHI, JOHN JR. & RAUSHI DOM & 404749 & 0744549 & $\mathbf{H}$ & 185 & 374LSVL \\
\hline $27-1699$ & FANNER, RAY AND ARLENE & FANNER DOM & 404825 & 0744348 & $\mathrm{H}$ & 85 & 374LSVL \\
\hline $27-1701$ & $\begin{array}{l}\text { WEST MORRIS REGIONAL HIGH-SCH - BD OF } \\
\text { ED }\end{array}$ & SCHOOL SUPPLY PW & 404835 & 0744342 & $\mathbf{T}$ & 300 & 374LSVL \\
\hline $27-1847$ & STATE OF NEW JERSEY & ANDACRES FARM 1 & 404629 & 0744631 & $\mathrm{U}$ & 472 & 374LSVL \\
\hline \multicolumn{8}{|c|}{ BOROUGH OF WHARTON } \\
\hline $27-0826$ & WHARTON WD & WBWD 1 & 405414 & 0743529 & $P$ & 42.0 & 112SFDF \\
\hline $27-0827$ & WHARTON WD & WBWD 2 & 405412 & 0743526 & $P$ & 32.0 & 112 SFDF \\
\hline $27-1192$ & STATE OF NJ & MORRIS MAINT YD 22 OBS & 405414 & 0743542 & $\mathbf{U}$ & 100 & 112SFDF \\
\hline $27-1703$ & BIRD, JOHN C & BIRD DOM BURIED & 405407 & 0743527 & $\mathbf{H}$ & 134 & 112SFDF \\
\hline
\end{tabular}

${ }^{1}$ Use of Water:

$\begin{array}{ll}\text { C - COMMERCIAL } & \text { N - INDUSTRIAL } \\ \text { H - DOMESTIC } & \text { P - PUBLIC SUPPLY } \\ \text { I - IRRIGATION } & \text { T - INSTITUTIONAL } \\ \text { J - INDUSTRIAL (COOLING) } & \text { U - UNUSED }\end{array}$

${ }^{2}$ Aquifer Codes:

112SFDF - VALLEY-FILL AQUIFER

350GRPD - GREEN POND CONGLOMERATE

374LSVL - LEITHSVILLE FORMATION

377HRDS - HARDYSTON QUARTZITE

400PCMB - PRECAMBRIAN GNEISS 
Appendix 2. Results of water-quality analyses of ground-water and surface-water samples from the New Jersey Highlands study area

[Aquifer codes: 112SFDF, stratified drift; 350GRPD, Green Pond conglomerate; 374SLVL, Leithsville dolomite; 400PCMB, Precambrian gneiss; Deg C, degrees Celsius; --, no data; $\mu \mathrm{S} / \mathrm{cm}$, microsiemens per centimeter at 25 degrees Celsius; $\mathrm{mg} / \mathrm{L}$, milligrams per liter; $\mu \mathrm{g} / \mathrm{L}$, micrograms per liter; $\mathrm{pCi} / \mathrm{L}$, picocuries per liter]

\begin{tabular}{|c|c|c|c|c|c|c|c|}
\hline $\begin{array}{c}\text { New } \\
\text { Jersey } \\
\text { well } \\
\text { number }\end{array}$ & $\begin{array}{l}\text { Aquifer } \\
\text { code }\end{array}$ & $\begin{array}{l}\text { Station } \\
\text { number }\end{array}$ & $\begin{array}{l}\text { Local } \\
\text { identifier }\end{array}$ & Date & Time & $\begin{array}{l}\text { Temper- } \\
\text { ature of } \\
\text { water } \\
(\operatorname{deg} C)\end{array}$ & $\begin{array}{l}\text { Oxygen, } \\
\text { dissolved } \\
(\mathrm{mg} / \mathrm{L})\end{array}$ \\
\hline 19-0255 & 112SFDF & 404354074494501 & MERRILL DOM & $11-01-89$ & 1030 & 11.0 & 9.8 \\
\hline $27-1089$ & $112 S F D F$ & 404955074392201 & CHUDOBA 1 & $08-10-88$ & 1230 & 11.5 & 5.4 \\
\hline $27-1091$ & 112SFDF & 405004074414801 & WIEN LABORATORIES 1 & $08-11-88$ & 1330 & 11.5 & 9.5 \\
\hline $27-1094$ & 112SFDF & 405053074375502 & MORRIS CO MUA B4 LOWER & 08-09-88 & 1600 & 13.0 & 1.8 \\
\hline $27-1095$ & 112SFDF & 405053074375501 & MORRIS CO MUA B4 UPPER & 08-09-88 & 1450 & 11.5 & .1 \\
\hline $27-1096$ & $112 \mathrm{SFDF}$ & 405021074382602 & MORRIS CO MUA B6 LOWER & $08-08-88$ & 1715 & 12.0 & 8.5 \\
\hline $27-1097$ & 112 SFDF & 405021074382601 & MORRIS CO MUA B6 UPPER & $08-08-88$ & 1630 & 12.0 & 10.1 \\
\hline $27-1098$ & 112SFDF & 405139074402701 & BOHS 1 & $08-11-88$ & 0945 & 11.5 & 7.1 \\
\hline $27-1100$ & 112SFDF & 405108074383601 & ROXBURY WATER CO 1 & $08-10-88$ & 1630 & 13.5 & 1.4 \\
\hline $27-1101$ & 112SFDF & 404910074432101 & GRABER 1 & $08-17-88$ & 1215 & 11.5 & 9.4 \\
\hline $27-1101$ & 112 SFDF & 404910074432101 & GRABER 1 & $08-17-88$ & 1215 & 11.5 & 9.4 \\
\hline $27-1101$ & 112 SFDF & 404910074432101 & GRABER 1 & $08-17-88$ & 1300 & 11.5 & 9.4 \\
\hline $27-1101$ & 112SFDF & 404910074432101 & GRABER 1 & $08-17-88$ & 1300 & 11.5 & 9.4 \\
\hline $27-1121$ & 112 SFDF & 404546074492401 & BEAM 1 & $08-23-88$ & 1030 & 12.0 & -- \\
\hline $27-1124$ & $112 S F D F$ & 405330074363802 & KENVIL NEWCRETE 2 OBS & $10-26-89$ & 1500 & 12.0 & .5 \\
\hline $27-1164$ & 112SFDF & 404809074415502 & BLACK RIVER 5 OBS & $05-02-90$ & 1400 & 11.0 & 6.2 \\
\hline $27-1165$ & 112SFDF & 404823074434401 & EBERBACH 1 & $10-31-89$ & 1600 & 11.0 & 8.5 \\
\hline $27-1167$ & 112SFDF & 404848074434201 & REDER DOM & $08-30-89$ & 1655 & 11.5 & 7.5 \\
\hline $27-1169$ & 112SFDF & 405010074412401 & WEB DYNAMICS IND & $08-30-89$ & 1410 & 13.0 & 12.9 \\
\hline $27-1172$ & 112SFDF & 405104074411001 & DAWSON DOM & $08-31-89$ & 1400 & 11.0 & 8.8 \\
\hline $27-1176$ & $112 S F D F$ & 405214074381901 & NIXON DOM & $08-31-89$ & 1010 & 13.0 & 11.0 \\
\hline $27-1177$ & $112 \mathrm{SFDF}$ & 405235074381801 & RWC PW6-KENTWOOD RD & $08-22-89$ & 0935 & 12.0 & .9 \\
\hline $27-1177$ & 112 SFDF & 405235074381801 & RWC PW6-KENTWOOD RD & $08-22-89$ & 0935 & 12.0 & .9 \\
\hline $27-1177$ & 112SFDF & 405235074381801 & RWC PW6-KENTWOOD RD & $08-22-89$ & 0955 & 12.0 & .9 \\
\hline $27-1177$ & $112 S F D F$ & 405235074381801 & RWC PW6-KENTWOOD RD & $08-22-89$ & 0955 & 12.0 & .9 \\
\hline $27-1180$ & $112 \mathrm{SFDF}$ & 405240074391501 & ANTANELIS DOM & $08-21-89$ & 1250 & 12.0 & 2.8 \\
\hline $27-1181$ & 112SFDF & 405245074392101 & BEAGLE DOM & $08-23-89$ & 0925 & 11.5 & 4.8 \\
\hline $27-1182$ & 112 SFDF & 405305074365901 & PETILLO ENTERPRISE COM & $08-25-89$ & 0920 & 12.5 & .7 \\
\hline $27-1183$ & 112SFDF & 405330074363803 & KENVIL NEWCRETE 7 OBS & $10-27-89$ & 1200 & 12.5 & 6.3 \\
\hline $27-1184$ & 112 SFDF & 405408074363701 & HERRS MOTOR EXPRESS COM & 08-23-89 & 1530 & 12.5 & 6.5 \\
\hline $27-1185$ & 112SFDF & 405431074362601 & ARENDASKY 1 & $08-24-89$ & 1705 & 11.5 & 7.5 \\
\hline $27-1187$ & 112 SFDF & 405443074363801 & HOLMES DOM & $08-24-89$ & 1355 & 11.5 & 5.6 \\
\hline $27-1188$ & 112 SFDF & 405444074363601 & L BERKSH V METH CHURCH 1 & $08-24-89$ & 0910 & 13.0 & 5.6 \\
\hline $27-1170$ & 350GRPD & 405054074410901 & ARICO DOM & 11-03-89 & 1400 & 10.5 & 10.2 \\
\hline $27-1174$ & 350GRPD & 405122074390501 & ROKA DOM & $10-31-89$ & 1200 & 11.5 & 5.8 \\
\hline $27-1186$ & 350GRPD & 405309074372701 & CHOPRA DOM & $10-25-89$ & 1330 & 12.0 & 8.8 \\
\hline 19-0237 & 374LSVL & 404252074505501 & KENNEDY 1 & $08-25-88$ & 1745 & 11.0 & 8.2 \\
\hline $19-0252$ & 374LSVL & 404216074514901 & $\begin{array}{l}\text { BAUMGARTNER DOM } \\
\text { REPLACE }\end{array}$ & $11-06-89$ & 1615 & 10.5 & 7.0 \\
\hline $19-0254$ & 374LSVL & 404318074500401 & JONES DOM & $11-01-89$ & 1330 & 11.5 & 7.8 \\
\hline $19-0256$ & 374LSVL & 404431074495801 & BARKMAN RT 513 STANDBY & $11-02-89$ & 1330 & 10.5 & 10.2 \\
\hline $19-0284$ & 374LSVL & 404440074502801 & MARTINO 1 & $08-26-88$ & 1315 & 11.5 & .0 \\
\hline $27-1090$ & 374LSVL & 405009074384701 & MORRIS CO MUA 5 & $08-09-88$ & 1330 & 11.5 & 5.5 \\
\hline $27-1092$ & 374LSVL & 404958074423701 & MT OLIVE TWP FLANDERS2 & $08-12-88$ & 1225 & 11.5 & 10 \\
\hline $27-1093$ & 374LSVL & 404902074423201 & MT OLIVE TWP FLANDERS3 & $08-12-88$ & 1000 & 11.5 & 6.6 \\
\hline $27-1099$ & 374LSVL & 405205074380901 & JAMES SMITH 1 & $08-09-88$ & 0915 & 13.0 & 6.8 \\
\hline
\end{tabular}


Appendix 2. Results of water-quality analyses of ground-water and surface-water samples from the New Jersey Highlands study area-Continued

\begin{tabular}{|c|c|c|c|c|c|c|c|c|}
\hline $\begin{array}{l}\text { New } \\
\text { Jersey } \\
\text { well } \\
\text { number }\end{array}$ & Date & Time & $\begin{array}{c}\text { Specific } \\
\text { conductance } \\
\text { field } \\
(\mu \mathrm{S} / \mathrm{cm})\end{array}$ & $\begin{array}{c}\text { Specific } \\
\text { conductance } \\
\text { lab } \\
(\mu \mathrm{S} / \mathrm{cm})\end{array}$ & $\begin{array}{l}\text { Nitrogen, } \\
\text { ammonia } \\
\text { dissolved } \\
(\mathrm{mg} / \mathrm{L} \text { as } \mathrm{N})\end{array}$ & $\begin{array}{c}\text { Nitrogen, } \\
\text { nitrite } \\
\text { dissolved } \\
(\mathrm{mg} / \mathrm{L} \text { as } \mathrm{N})\end{array}$ & $\begin{array}{c}\text { Nitrogen, } \\
\text { ammonia }+ \\
\text { organic } \\
\text { dissolved } \\
(\mathrm{mg} / \mathrm{L} \text { as } \mathrm{N})\end{array}$ & $\begin{array}{c}\text { Nitrogen, } \\
\mathrm{NO}_{2}+\mathrm{NO}_{3} \\
\text { dissolved } \\
(\mathrm{mg} / \mathrm{L} \text { as } \mathrm{N})\end{array}$ \\
\hline $19-0255$ & $11-01-89$ & 1030 & 87 & 147 & $<0.010$ & $<0.010$ & 0.30 & 1.00 \\
\hline $27-1089$ & $08-10-88$ & 1230 & 94 & -- & $<.010$ & $<.010$ & .30 & 1.90 \\
\hline $27-1091$ & $08-11-88$ & 1330 & 86 & -- & $<.010$ & $<.010$ & .30 & 3.20 \\
\hline $27-1094$ & $08-09-88$ & 1600 & 147 & -- & .070 & $<.010$ & .80 & .220 \\
\hline $27-1095$ & $08-09-88$ & 1450 & 250 & -- & .090 & .020 & .50 & $<.100$ \\
\hline $27-1096$ & $08-08-88$ & 1715 & 75 & -- & $<.010$ & $<.010$ & 3.4 & $<.100$ \\
\hline $27-1097$ & $08-08-88$ & 1630 & 44 & -- & .010 & $<.010$ & 1.1 & 1.80 \\
\hline $27-1098$ & $08-11-88$ & 0945 & 103 & -- & $<.010$ & $<.010$ & .30 & 1.50 \\
\hline $27-1100$ & $08-10-88$ & 1630 & 351 & -- & $<.010$ & $<.010$ & $<.20$ & 1.70 \\
\hline $27-1101$ & $08-17-88$ & 1215 & 175 & -- & $<.010$ & $<.010$ & .40 & $<.100$ \\
\hline $27-1101$ & $08-17-88$ & 1215 & 175 & -- & $<.010$ & $<.010$ & .40 & $<.100$ \\
\hline $27-1101$ & $08-17-88$ & 1300 & 175 & -- & $<.010$ & $<.010$ & .40 & $<.100$ \\
\hline $27-1101$ & $08-17-88$ & 1300 & 175 & -- & $<.010$ & $<.010$ & .40 & $<.100$ \\
\hline $27-1121$ & $08-23-88$ & 1030 & 206 & -- & $<.010$ & $<.010$ & .20 & .460 \\
\hline $27-1124$ & $10-26-89$ & 1500 & 390 & 392 & .010 & .010 & $<.20$ & .590 \\
\hline $27-1164$ & $05-02-90$ & 1400 & 155 & 147 & $<.010$ & $<.010$ & $<.20$ & 2.30 \\
\hline $27-1165$ & $10-31-89$ & 1600 & 232 & 239 & $<.010$ & $<.010$ & .20 & 2.50 \\
\hline $27-1167$ & $08-30-89$ & 1655 & 163 & 167 & .010 & $<.010$ & $<.20$ & .660 \\
\hline $27-1169$ & $08-30-89$ & 1410 & 161 & 165 & .010 & $<.010$ & .40 & 5.30 \\
\hline $27-1172$ & $08-31-89$ & 1400 & 82 & 81 & $<.010$ & $<.010$ & .80 & .700 \\
\hline $27-1176$ & $08-31-89$ & 1010 & 20 & $2 I$ & .010 & $<.010$ & $<.20$ & .340 \\
\hline $27-1177$ & $08-22-89$ & 0935 & -- & 453 & $<.010$ & $<.010$ & 1.2 & .700 \\
\hline $27-1177$ & $08-22-89$ & 0935 & -- & 453 & $<.010$ & $<.010$ & 1.2 & .700 \\
\hline $27-1177$ & $08-22-89$ & 0955 & 322 & 460 & $<.010$ & $<.010$ & .30 & .710 \\
\hline $27-1177$ & $08-22-89$ & 0955 & 322 & 460 & $<.010$ & $<.010$ & .30 & .710 \\
\hline $27-1180$ & $08-21-89$ & 1250 & -- & 480 & $<.010$ & $<.010$ & 2.1 & 1.90 \\
\hline $27-1181$ & 08-23-89 & 0925 & 480 & 501 & $<.010$ & $<.010$ & .30 & 2.00 \\
\hline $27-1182$ & $08-25-89$ & 0920 & 205 & 220 & $<.010$ & $<.010$ & .20 & .350 \\
\hline $27-1183$ & $10-27-89$ & 1200 & 407 & 413 & $<.010$ & $<.010$ & .30 & 1.40 \\
\hline $27-1184$ & 08-23-89 & 1530 & 310 & 320 & $<.010$ & $<.010$ & 1.8 & 1.70 \\
\hline $27-1185$ & $08-24-89$ & 1705 & 430 & 466 & $<.010$ & $<.010$ & 1.8 & 2.60 \\
\hline $27-1187$ & $08-24-89$ & 1355 & 170 & 194 & $<.010$ & $<.010$ & .70 & .190 \\
\hline $27-1188$ & $08-24-89$ & 0910 & 570 & 627 & .020 & $<.010$ & 2.3 & 6.10 \\
\hline $27-1170$ & $11-03-89$ & 1400 & 29 & 19 & $<.010$ & $<.010$ & $<.20$ & .360 \\
\hline $27-1174$ & $10-31-89$ & 1200 & 236 & 280 & $<.010$ & $<.010$ & .40 & 8.30 \\
\hline $27-1186$ & $10-25-89$ & 1330 & 415 & 420 & .010 & $<.010$ & .40 & 2.10 \\
\hline $19-0237$ & $08-25-88$ & 1745 & 245 & -- & $<.010$ & $<.010$ & .40 & .690 \\
\hline $19-0252$ & $11-06-89$ & 1615 & 320 & 327 & .030 & $<.010$ & .20 & 2.00 \\
\hline $19-0254$ & I1-0I-89 & 1330 & 119 & 107 & $<.010$ & $<.010$ & .20 & .210 \\
\hline I9-0256 & $1 \mathrm{I}-02-89$ & 1330 & 406 & 409 & $<.010$ & $<.010$ & .60 & 4.40 \\
\hline $19-0284$ & $08-26-88$ & 1315 & 270 & -- & $<.010$ & $<.010$ & .30 & $<.100$ \\
\hline $27-1090$ & $08-09-88$ & 1330 & 161 & -. & -- & -- & -- & -- \\
\hline $27-1092$ & $08-12-88$ & 1225 & 302 & -- & $<.010$ & $<.010$ & .20 & .980 \\
\hline $27-1093$ & $08-12-88$ & 1000 & 249 & -- & $<.010$ & $<.010$ & .30 & 1.40 \\
\hline $27-1099$ & $08-09-88$ & 0915 & 134 & -- & .010 & $<.010$ & .90 & .740 \\
\hline
\end{tabular}


Appendix 2. Results of water-quality analyses of ground-water and surface-water samples from the New Jersey Highlands study area--Continued

\begin{tabular}{|c|c|c|c|c|c|c|c|c|}
\hline $\begin{array}{c}\text { New } \\
\text { Jersey } \\
\text { well } \\
\text { number }\end{array}$ & Date & Time & $\begin{array}{c}\mathrm{pH} \\
\text { (standard } \\
\text { units) }\end{array}$ & $\begin{array}{c}\mathrm{pH} \\
\text { lab } \\
\text { (standard } \\
\text { units) }\end{array}$ & $\begin{array}{l}\text { Alkalinity, } \\
\text { field } \\
\left(\mathrm{mg}^{2} \mathrm{~L} \text { as }\right. \\
\left.\mathrm{CaCO}_{3}\right)\end{array}$ & $\begin{array}{c}\text { Alkalinity, } \\
\text { lab } \\
\left(\mathrm{mg}^{2} \mathrm{~L} \text { as }\right. \\
\left.\mathrm{CaCO}_{3}\right)\end{array}$ & $\begin{array}{l}\text { Phosphorus } \\
\text { ortho, } \\
\text { dissolved } \\
\text { (mg/L as } \mathrm{P} \text { ) }\end{array}$ & $\begin{array}{c}\text { Carbon } \\
\text { organic, } \\
\text { dissolved } \\
(\mathrm{mg} / \mathrm{L} \text { as } \mathrm{C})\end{array}$ \\
\hline $19-0255$ & $11-01-89$ & 1030 & 6.2 & 7.6 & -- & 61 & 0.020 & 0.2 \\
\hline $27-1089$ & $08-10-88$ & 1230 & 6.8 & -- & 32 & 32 & .020 & 1.7 \\
\hline $27-1091$ & $08-11-88$ & 1330 & 6.4 & -- & 27 & 22 & .030 & 1.7 \\
\hline $27-1094$ & $08-09-88$ & 1600 & 7.6 & -- & 62 & 64 & .030 & 1.9 \\
\hline $27-1095$ & $08-09-88$ & 1450 & 7.1 & -- & 69 & 53 & .030 & 1.7 \\
\hline $27-1096$ & $08-08-88$ & 1715 & 7.6 & -- & 38 & 34 & .080 & 1.0 \\
\hline $27-1097$ & $08-08-88$ & 1630 & 5.8 & -- & 9 & 9 & $<.010$ & 1.5 \\
\hline $27-1098$ & $08-11-88$ & 0945 & 6.0 & -- & 25 & 22 & $<.010$ & 1.5 \\
\hline $27-1100$ & $08-10-88$ & 1630 & 6.4 & -- & 74 & 69 & $<.010$ & 2.1 \\
\hline $27-1101$ & $08-17-88$ & 1215 & 7.4 & -- & 71 & 68 & .020 & .5 \\
\hline $27-1101$ & $08-17-88$ & 1215 & 7.4 & -- & 71 & 68 & .020 & .5 \\
\hline $27-1101$ & $08-17-88$ & 1300 & 7.4 & -- & 71 & 68 & .020 & .5 \\
\hline $27-1101$ & $08-17-88$ & 1300 & 7.4 & -- & 71 & 68 & .020 & .5 \\
\hline $27-1121$ & $08-23-88$ & 1030 & 8.3 & -. & 75 & 70 & .020 & .9 \\
\hline $27-1124$ & $10-26-89$ & 1500 & 8.1 & 7.9 & 76 & 77 & .040 & .5 \\
\hline $27-1164$ & $05-02-90$ & 1400 & 6.7 & 7.4 & 72 & 58 & .030 & .5 \\
\hline $27-1165$ & $10-31-89$ & 1600 & 7.2 & 7.8 & -- & 96 & .020 & .2 \\
\hline $27-1167$ & $08-30-89$ & 1655 & 6.7 & 7.1 & 72 & 72 & $<.010$ & .3 \\
\hline $27-1169$ & $08-30-89$ & 1410 & 6.9 & 7.4 & 56 & 56 & .020 & .2 \\
\hline $27-1172$ & $08-31-89$ & 1400 & 5.6 & 6.0 & 13 & 14 & $<.010$ & .3 \\
\hline $27-1176$ & $08-31-89$ & 1010 & 5.1 & 5.9 & 6 & 6 & $<.010$ & .3 \\
\hline $27-1177$ & $08-22-89$ & 0935 & 7.1 & 7.3 & 139 & 139 & .050 & 1.2 \\
\hline $27-1177$ & $08-22-89$ & 0935 & 7.1 & 7.3 & 139 & 139 & .050 & 1.2 \\
\hline $27-1177$ & $08-22-89$ & 0955 & 7.1 & 7.3 & 139 & 139 & .050 & 1.0 \\
\hline $27-1177$ & $08-22-89$ & 0955 & 7.1 & 7.3 & 139 & 139 & .050 & 1.0 \\
\hline $27-1180$ & $08-21-89$ & 1250 & 6.8 & 7.0 & 82 & 90 & $<.010$ & .8 \\
\hline $27-1181$ & $08-23-89$ & 0925 & 7.0 & 7.2 & 109 & 107 & .020 & .8 \\
\hline $27-1182$ & $08-25-89$ & 0920 & 8.2 & 7.9 & 111 & 110 & .040 & 1.0 \\
\hline $27-1183$ & $10-27-89$ & 1200 & 7.8 & 7.7 & 131 & 126 & $<.010$ & .5 \\
\hline $27-1184$ & 08-23-89 & 1530 & 7.9 & 7.9 & 115 & 119 & $<.010$ & .6 \\
\hline $27-1185$ & $08-24-89$ & 1705 & 7.9 & 8.0 & 150 & 156 & .010 & .7 \\
\hline $27-1187$ & $08-24-89$ & 1355 & 8.2 & 7.9 & 83 & 85 & .110 & .4 \\
\hline $27-1188$ & $08-24-89$ & 0910 & 6.9 & 7.0 & 171 & 167 & $<.010$ & .8 \\
\hline $27-1170$ & $11-03-89$ & 1400 & 5.7 & 5.7 & 7 & 6 & $<.010$ & .2 \\
\hline $27-1174$ & $10-31-89$ & 1200 & 5.6 & 6.0 & 21 & 18 & $<.010$ & .4 \\
\hline $27-1186$ & $10-25-89$ & 1330 & 5.2 & 5.8 & 2 & 5 & $<.010$ & 1.4 \\
\hline $19-0237$ & $08-25-88$ & 1745 & 8.3 & -- & 127 & 110 & .010 & .7 \\
\hline $19-0252$ & $11-06-89$ & 1615 & 8.1 & 7.8 & 120 & 108 & .030 & .6 \\
\hline $19-0254$ & $11-01-89$ & 1330 & 6.6 & 6.5 & 29 & 29 & .010 & .4 \\
\hline $19-0256$ & $11-02-89$ & 1330 & 7.4 & 7.7 & -- & 170 & $<.010$ & .4 \\
\hline $19-0284$ & $08-26-88$ & 1315 & 8.3 & -- & 117 & 112 & .010 & .6 \\
\hline $27-1090$ & $08-09-88$ & 1330 & 8.6 & -- & 72 & 72 & -. & 1.4 \\
\hline $27-1092$ & $08-12-88$ & 1225 & 7.7 & -- & 96 & 99 & .020 & 1.6 \\
\hline $27-1093$ & $08-12-88$ & 1000 & 8.3 & -- & 96 & 102 & .010 & 1.6 \\
\hline $27-1099$ & $08-09-88$ & 0915 & 8.4 & -- & 61 & 64 & .010 & 2.4 \\
\hline
\end{tabular}


Appendix 2. Results of water-quality analyses of ground-water and surface-water samples from the New Jersey Hiahlands study areg-Continued

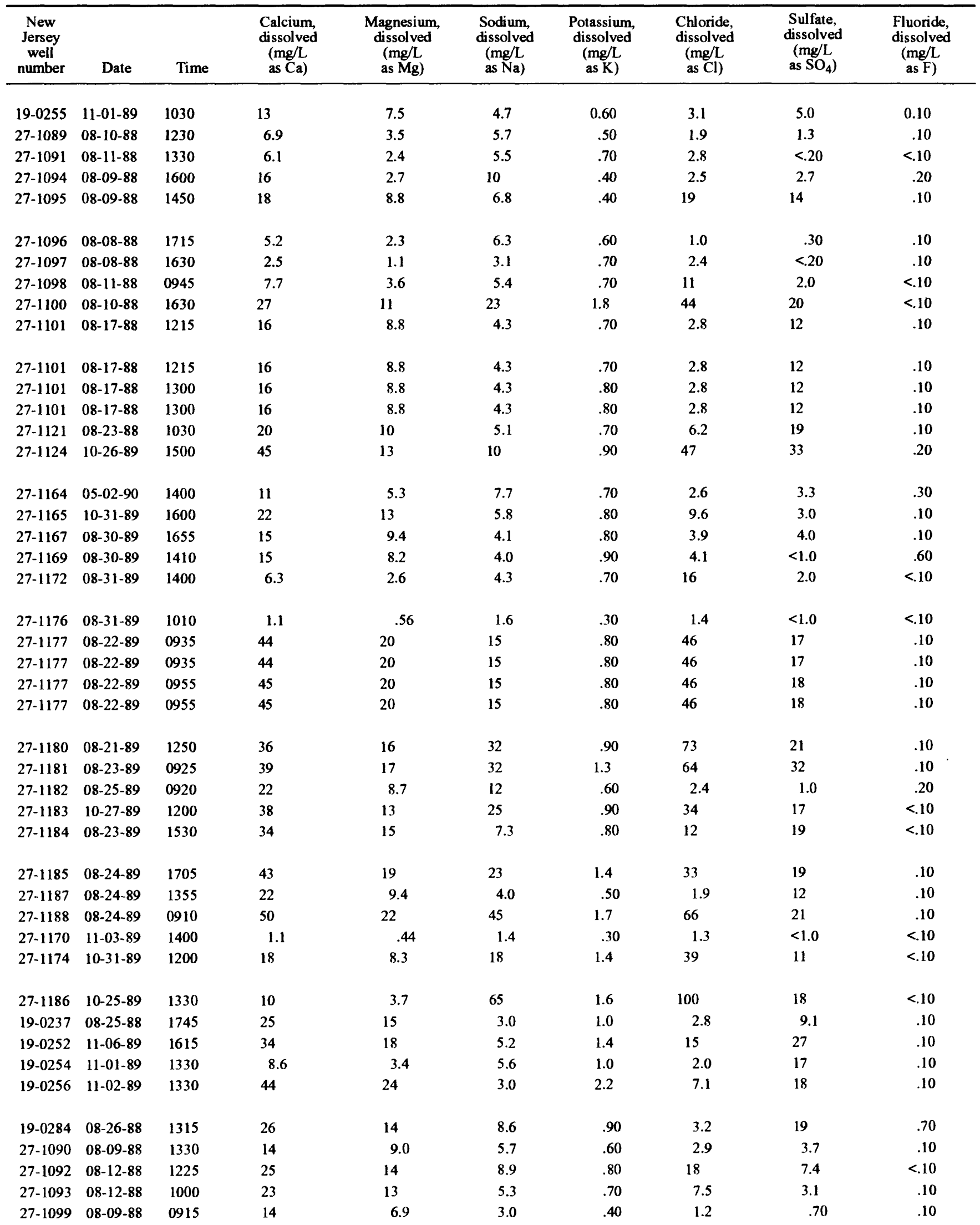




\begin{tabular}{|c|c|c|c|c|c|c|c|c|c|}
\hline $\begin{array}{c}\text { New } \\
\text { Jersey } \\
\text { well } \\
\text { number }\end{array}$ & Date & Time & $\begin{array}{c}\text { Silica, } \\
\text { dissolved } \\
(\mathrm{mg} / \mathrm{L} \\
\left.\text { as } \mathrm{SiO}_{2}\right)\end{array}$ & $\begin{array}{c}\text { Arsenic, } \\
\text { dissolved } \\
(\mu \mathrm{g} / \mathrm{L} \\
\text { as As })\end{array}$ & $\begin{array}{c}\text { Barium, } \\
\text { dissolved } \\
(\mu \mathrm{g} / \mathrm{L} \\
\text { as Ba })\end{array}$ & $\begin{array}{c}\text { Beryllium, } \\
\text { dissolved } \\
(\mu \mathrm{g} / \mathrm{L} \\
\text { as } \mathrm{Be})\end{array}$ & $\begin{array}{c}\text { Cadmium, } \\
\text { dissolved } \\
(\mu \mathrm{g} / \mathrm{L} \\
\text { as Cd })\end{array}$ & $\begin{array}{c}\text { Chromium, } \\
\text { dissolved } \\
(\mu \mathrm{g} / \mathrm{L} \\
\text { as } \mathrm{Cr})\end{array}$ & $\begin{array}{c}\text { Cobalt, } \\
\text { dissolved } \\
(\mu \mathrm{g} / \mathrm{L} \\
\text { as Co) }\end{array}$ \\
\hline $19-0255$ & $11-01-89$ & 1030 & 17 & $<1$ & 2 & $<0.5$ & $<1.0$ & $<5$ & $<3$ \\
\hline $27-1089$ & $08-10-88$ & 1230 & 29 & -- & 14 & $<.5$ & 1.0 & $<5$ & $<3$ \\
\hline $27-1091$ & $08-11-88$ & 1330 & 26 & - & 15 & $<.5$ & 1.0 & $<5$ & $<3$ \\
\hline $27-1094$ & $08-09-88$ & 1600 & 19 & -- & 5 & $<.5$ & $<1.0$ & $<5$ & $<3$ \\
\hline $27-1095$ & $08-09-88$ & 1450 & 24 & - & 16 & $<.5$ & 2.0 & $<5$ & $<3$ \\
\hline $27-1096$ & 08-08-88 & 1715 & 20 & -- & 5 & $<.5$ & $<1.0$ & $<5$ & $<3$ \\
\hline $27-1097$ & 08-08-88 & 1630 & 12 & -- & 12 & $<.5$ & 2.0 & $<5$ & $<3$ \\
\hline $27-1098$ & $08-11-88$ & 0945 & 21 & -- & 11 & $<.5$ & $<1.0$ & $<5$ & $<3$ \\
\hline $27-1100$ & $08-10-88$ & 1630 & 12 & - & 20 & $<.5$ & 1.0 & $<5$ & $<3$ \\
\hline $27-1101$ & $08-17-88$ & 1215 & 16 & - & 13 & $<.5$ & $<1.0$ & $<5$ & $<3$ \\
\hline $27-1101$ & $08-17-88$ & 1215 & 16 & -- & 13 & $<.5$ & $<1.0$ & $<5$ & $<3$ \\
\hline $27-1101$ & $08-17-88$ & 1300 & 16 & -- & 13 & $<.5$ & $<1.0$ & $<5$ & $<3$ \\
\hline $27-1101$ & $08-17-88$ & 1300 & 16 & -- & 13 & $<.5$ & $<1.0$ & $<5$ & $<3$ \\
\hline $27-1121$ & $08-23-88$ & 1030 & 21 & -- & 22 & $<.5$ & 1.0 & $<5$ & $<3$ \\
\hline $27-1124$ & $10-26-89$ & 1500 & 13 & 1 & 11 & $<.5$ & $<1.0$ & $<5$ & $<3$ \\
\hline $27-1164$ & $05-02-90$ & 1400 & 18 & $<1$ & 25 & $<.5$ & $<1.0$ & $<5$ & $<3$ \\
\hline $27-1165$ & $10-31-89$ & 1600 & 18 & $<1$ & 14 & $<.5$ & $<1.0$ & $<5$ & $<3$ \\
\hline $27-1167$ & $08-30-89$ & 1655 & 20 & $<1$ & 15 & $<.5$ & $<1.0$ & $<5$ & $<3$ \\
\hline $27-1169$ & $08-30-89$ & 1410 & 19 & $<1$ & 24 & $<.5$ & $<1.0$ & $<5$ & $<3$ \\
\hline $27-1172$ & $08-31-89$ & 1400 & 12 & $<1$ & 14 & $<.5$ & $<1.0$ & $<5$ & $<3$ \\
\hline $27-1176$ & $08-31-89$ & 1010 & 6.4 & $<1$ & 4 & $<.5$ & $<1.0$ & $<5$ & $<3$ \\
\hline $27-1177$ & $08-22-89$ & 0935 & 16 & $<1$ & 5 & $<.5$ & $<1.0$ & $<5$ & $<3$ \\
\hline $27-1177$ & $08-22-89$ & 0935 & 16 & $<1$ & 5 & $<.5$ & $<1.0$ & $<5$ & $<3$ \\
\hline $27-1177$ & $08-22-89$ & 0955 & 16 & $<1$ & 5 & $<.5$ & $<1.0$ & $<5$ & $<3$ \\
\hline $27-1177$ & $08-22-89$ & 0955 & 16 & $<1$ & 5 & $<.5$ & $<1.0$ & $<5$ & $<3$ \\
\hline $27-1180$ & $08-21-89$ & 1250 & 15 & $<1$ & 26 & $<.5$ & $<1.0$ & $<5$ & $<3$ \\
\hline $27-1181$ & $08-23-89$ & 0925 & 17 & $<1$ & 21 & $<.5$ & $<1.0$ & $<5$ & $<3$ \\
\hline $27-1182$ & $08-25-89$ & 0920 & 14 & $<1$ & 12 & $<.5$ & $<1.0$ & $<5$ & $<3$ \\
\hline $27-1183$ & $10-27-89$ & 1200 & 18 & $<1$ & 11 & $<.5$ & $<1.0$ & $<5$ & $<3$ \\
\hline $27-1184$ & 08-23-89 & 1530 & 16 & $<1$ & 8 & $<.5$ & $<1.0$ & $<5$ & $<3$ \\
\hline $27-1185$ & $08-24-89$ & 1705 & 21 & $<1$ & 12 & $<.5$ & $<1.0$ & $<5$ & $<3$ \\
\hline $27-1187$ & $08-24-89$ & 1355 & 17 & $<1$ & 3 & $<.5$ & $<1.0$ & $<5$ & $<3$ \\
\hline $27-1188$ & 08-24-89 & 0910 & 19 & $<1$ & 25 & $<.5$ & $<1.0$ & $<5$ & $<3$ \\
\hline $27-1170$ & 11-03-89 & 1400 & 7.0 & $<1$ & 5 & $<.5$ & $<1.0$ & $<5$ & $<3$ \\
\hline $27-1174$ & $10-31-89$ & 1200 & 14 & $<1$ & 53 & $<.5$ & $<1.0$ & $<5$ & $<3$ \\
\hline $27-1186$ & $10-25-89$ & 1330 & 7.8 & $<1$ & 42 & $<.5$ & $<1.0$ & $<5$ & $<3$ \\
\hline $19-0237$ & $08-25-88$ & 1745 & 18 & -- & 8 & $<.5$ & $<1.0$ & $<5$ & $<3$ \\
\hline 19-0252 & 11-06-89 & 1615 & 18 & $<1$ & 8 & $<.5$ & $<1.0$ & $<5$ & $<3$ \\
\hline $19-0254$ & 11-01-89 & 1330 & 20 & $<1$ & 9 & $<.5$ & $<1.0$ & $<5$ & $<3$ \\
\hline $19-0256$ & $11-02-89$ & 1330 & 7.5 & $<1$ & 34 & $<.5$ & $<1.0$ & $<5$ & $<3$ \\
\hline $19-0284$ & $08-26-88$ & 1315 & 18 & .. & 62 & $<.5$ & $<1.0$ & $<5$ & $<3$ \\
\hline $27-1090$ & 08-09-88 & 1330 & 16 & -- & 7 & $<.5$ & $<1.0$ & $<5$ & $<3$ \\
\hline 27-1092 & $08-12-88$ & 1225 & 19 & - & 19 & $<.5$ & $<1.0$ & $<5$ & $<3$ \\
\hline $27-1093$ & $08-12-88$ & 1000 & 18 & -- & 15 & $<.5$ & $<1.0$ & $<5$ & $<3$ \\
\hline $27-1099$ & $08-09-88$ & 0915 & 11 & -- & 4 & $<.5$ & 1.0 & $<5$ & $<3$ \\
\hline
\end{tabular}


Appendix 2. Results of water-quality analyses of ground-water and surface-water samples from the New Jersey Highlands study area-Continued

\begin{tabular}{|c|c|c|c|c|c|c|c|c|c|}
\hline $\begin{array}{c}\text { New } \\
\text { Jersey } \\
\text { well } \\
\text { number }\end{array}$ & Date & Time & $\begin{array}{l}\text { Copper, } \\
\text { dissolved } \\
(\mu \mathrm{g} / \mathrm{L} \\
\text { as } \mathrm{Cu})\end{array}$ & $\begin{array}{c}\text { Iron, } \\
\text { dissolved } \\
(\mu \mathrm{g} / \mathrm{L} \\
\text { as Fe })\end{array}$ & $\begin{array}{l}\text { Lead, } \\
\text { dissolved } \\
((\mu \mathrm{g} / \mathrm{L} \\
\text { as } \mathrm{Pb})\end{array}$ & $\begin{array}{c}\text { Manganese, } \\
\text { dsissolved } \\
(\mu g / L \\
\text { as } M n)\end{array}$ & $\begin{array}{c}\text { Molybdenum, } \\
\text { dissolved } \\
(\mu \mathrm{g} / \mathrm{L} \\
\text { as Mo })\end{array}$ & $\begin{array}{c}\text { Nickel, } \\
\text { dissolved } \\
(\mu \mathrm{g} / \mathrm{L} \\
\text { as } \mathrm{Ni})\end{array}$ & $\begin{array}{c}\text { Silver, } \\
\text { dissolved } \\
(\mu \mathrm{g} / \mathrm{L} \\
\text { as } \mathrm{Ag})\end{array}$ \\
\hline $19-0255$ & 11-01-89 & 1030 & $<10$ & $<3$ & $<10$ & 1 & $<10$ & $<10$ & $<1.0$ \\
\hline $27-1089$ & $08-10-88$ & 1230 & $<10$ & 3 & $<10$ & 1 & $<10$ & $<10$ & $<1.0$ \\
\hline $27-1091$ & $08-11-88$ & 1330 & 30 & 5 & $<10$ & 3 & $<10$ & 10 & $<1.0$ \\
\hline $27-1094$ & 08-09-88 & 1600 & $<10$ & 290 & $<10$ & 69 & 20 & $<10$ & $<1.0$ \\
\hline $27-1095$ & $08-09-88$ & 1450 & $<10$ & 9,600 & $<10$ & 300 & $<10$ & 10 & $<1.0$ \\
\hline $27-1096$ & $08-08-88$ & 1715 & $<10$ & 9 & $<10$ & $<1$ & $<10$ & $<10$ & 2.0 \\
\hline 27-1097 & $08-08-88$ & 1630 & $<10$ & 4 & $<10$ & 15 & $<10$ & $<10$ & 2.0 \\
\hline $27-1098$ & $08-11-88$ & 0945 & 30 & 15 & $<10$ & 6 & $<10$ & $<10$ & $<1.0$ \\
\hline $27-1100$ & $08-10-88$ & 1630 & 10 & 39 & $<10$ & 75 & $<10$ & $<10$ & $<1.0$ \\
\hline $27-1101$ & $08-17-88$ & 1215 & $<10$ & 4 & $<10$ & $<1$ & $<10$ & $<10$ & $<1.0$ \\
\hline $27-1101$ & $08-17-88$ & 1215 & $<10$ & 4 & $<10$ & $<1$ & $<10$ & $<10$ & $<1.0$ \\
\hline $27-1101$ & $08-17-88$ & 1300 & $<10$ & $<3$ & $<10$ & $<1$ & $<10$ & $<10$ & $<1.0$ \\
\hline $27-1101$ & $08-17-88$ & 1300 & $<10$ & $<3$ & $<10$ & $<1$ & $<10$ & $<10$ & $<1.0$ \\
\hline $27-1121$ & $08-23-88$ & 1030 & $<10$ & 6 & $<10$ & $<1$ & $<10$ & $<10$ & 1.0 \\
\hline $27-1124$ & $10-26-89$ & 1500 & $<10$ & 69 & $<10$ & 30 & $<10$ & $<10$ & 1.0 \\
\hline $27-1164$ & $05-02-90$ & 1400 & $<10$ & 16 & 30 & 5 & $<10$ & $<10$ & $<1.0$ \\
\hline $27-1165$ & $10-31-89$ & 1600 & 20 & 4 & $<10$ & $<1$ & $<10$ & $<10$ & $<1.0$ \\
\hline $27-1167$ & $08-30-89$ & 1655 & $<10$ & 12 & $<10$ & $<1$ & $<10$ & $<10$ & $<1.0$ \\
\hline $27-1169$ & $08-30-89$ & 1410 & 20 & 13 & $<10$ & $<1$ & $<10$ & $<10$ & $<1.0$ \\
\hline $27-1172$ & $08-31-89$ & 1400 & $<10$ & 13 & 20 & $<1$ & $<10$ & $<10$ & $<1.0$ \\
\hline $27-1176$ & $08-31-89$ & 1010 & $<10$ & 66 & 20 & 5 & $<10$ & 10 & $<1.0$ \\
\hline $27-1177$ & $08-22-89$ & 0935 & $<10$ & 6 & $<10$ & $<1$ & $<10$ & $<10$ & 2.0 \\
\hline 27-1177 & $08-22-89$ & 0935 & $<10$ & 6 & $<10$ & $<1$ & $<10$ & $<10$ & 2.0 \\
\hline $27-1177$ & $08-22-89$ & 0955 & $<10$ & 6 & $<10$ & $<1$ & $<10$ & $<10$ & $<1.0$ \\
\hline $27-1177$ & $08-22-89$ & 0955 & $<10$ & 6 & $<10$ & $<1$ & $<10$ & $<10$ & $<1.0$ \\
\hline $27-1180$ & $08-21-89$ & 1250 & $<10$ & 29 & $<10$ & 2 & $<10$ & $<10$ & $<1.0$ \\
\hline $27-1181$ & $08-23-89$ & 0925 & $<10$ & 6 & $<10$ & $<1$ & $<10$ & $<10$ & $<1.0$ \\
\hline $27-1182$ & $08-25-89$ & 0920 & $<10$ & 21 & $<10$ & 16 & $<10$ & $<10$ & $<1.0$ \\
\hline $27-1183$ & $10-27-89$ & 1200 & $<10$ & $<3$ & $<10$ & 2 & $<10$ & $<10$ & $<1.0$ \\
\hline $27-1184$ & $08-23-89$ & 1530 & $<10$ & 9 & $<10$ & $<1$ & $<10$ & $<10$ & 2.0 \\
\hline $27-1185$ & $08-24-89$ & 1705 & $<10$ & 9 & 10 & $<1$ & $<10$ & $<10$ & 2.0 \\
\hline $27-1187$ & $08-24-89$ & 1355 & $<10$ & 6 & $<10$ & $<1$ & $<10$ & $<10$ & $<1.0$ \\
\hline $27-1188$ & $08-24-89$ & 0910 & $<10$ & 24 & $<10$ & 2 & $<10$ & $<10$ & $<1.0$ \\
\hline $27-1170$ & $11-03-89$ & 1400 & 10 & 45 & 30 & 4 & $<10$ & $<10$ & $<1.0$ \\
\hline $27-1174$ & $10-31-89$ & 1200 & 20 & 37 & 10 & 6 & $<10$ & $<10$ & $<1.0$ \\
\hline $27-1186$ & $10-25-89$ & 1330 & $<10$ & 13 & $<10$ & 59 & $<10$ & $<10$ & $<1.0$ \\
\hline $19-0237$ & $08-25-88$ & 1745 & $<10$ & 3 & $<10$ & $<1$ & $<10$ & $<10$ & $<1.0$ \\
\hline $19-0252$ & $11-06-89$ & 1615 & $<10$ & 4 & $<10$ & $<1$ & $<10$ & $<10$ & $<1.0$ \\
\hline $19-0254$ & $11-01-89$ & 1330 & $<10$ & 8 & $<10$ & $<1$ & $<10$ & $<10$ & $<1.0$ \\
\hline $19-0256$ & $11-02-89$ & 1330 & $<10$ & $<3$ & 10 & $<1$ & $<10$ & $<10$ & 2.0 \\
\hline $19-0284$ & $08-26-88$ & 1315 & $<10$ & 36 & $<10$ & 27 & $<10$ & $<10$ & $<1.0$ \\
\hline $27-1090$ & $08-09-88$ & 1330 & $<10$ & 16 & $<10$ & 1 & $<10$ & $<10$ & $<1.0$ \\
\hline $27-1092$ & $08-12-88$ & 1225 & $<10$ & 5 & $<10$ & $<1$ & $<10$ & $<10$ & $<1.0$ \\
\hline $27-1093$ & $08-12-88$ & 1000 & $<10$ & $<3$ & $<10$ & $<1$ & $<10$ & $<10$ & $<1.0$ \\
\hline $27-1099$ & $08-09-88$ & 0915 & $<10$ & 26 & $<10$ & 3 & $<10$ & $<10$ & 1.0 \\
\hline
\end{tabular}


Appendix 2. Results of water-quality analyses of ground-water and surface-water samples from the New Jersey Highlands study area-Continued

\begin{tabular}{|c|c|c|c|c|c|c|c|c|}
\hline $\begin{array}{l}\text { New } \\
\text { Jersey } \\
\text { well } \\
\text { number }\end{array}$ & Date & Time & $\begin{array}{c}\text { Strontium, } \\
\text { dissolved } \\
(\mu \mathrm{g} / \mathrm{L} \\
\text { as } \mathrm{Sr})\end{array}$ & $\begin{array}{c}\text { Vanadium } \\
\text { dissolved } \\
(\mu \mathrm{g} / \mathrm{L} \\
\text { as V) }\end{array}$ & $\begin{array}{c}\text { Zinc, } \\
\text { dissolved } \\
(\mu \mathrm{g} / \mathrm{L} \\
\text { as } \mathrm{Zn})\end{array}$ & $\begin{array}{c}\text { Aluminum, } \\
\text { dissolved } \\
(\mu \mathrm{g} / \mathrm{L} \\
\text { as } \mathrm{Al})\end{array}$ & $\begin{array}{l}\text { Lithium, } \\
\text { dissolved } \\
(\mu \mathrm{g} / \mathrm{L} \\
\text { as } \mathrm{Li})\end{array}$ & $\begin{array}{c}\text { Bromide, } \\
\text { dissolved } \\
(\mu \mathrm{g} / \mathrm{L} \\
\text { as } \mathrm{Br})\end{array}$ \\
\hline $19-0255$ & $11-01-89$ & 1030 & 25 & $<6$ & 80 & $<10$ & $<4$ & 0.020 \\
\hline $27-1089$ & $08-10-88$ & 1230 & 30 & $<6$ & $<3$ & $<10$ & $<4$ & .029 \\
\hline $27-1091$ & $08-11-88$ & 1330 & 40 & $<6$ & 8 & 10 & $<4$ & .018 \\
\hline $27-1094$ & 08-09-88 & 1600 & 36 & $<6$ & $<3$ & 20 & $<4$ & .013 \\
\hline $27-1095$ & $08-09-88$ & 1450 & 36 & $<6$ & $<3$ & 10 & $<4$ & .097 \\
\hline $27-1096$ & $08-08-88$ & 1715 & 20 & $<6$ & 6 & 10 & $<4$ & .023 \\
\hline $27-1097$ & $08-08-88$ & 1630 & 18 & $<6$ & $<3$ & 10 & $<4$ & .014 \\
\hline $27-1098$ & $08-11-88$ & 0945 & 44 & $<6$ & 6 & $<10$ & $<4$ & .034 \\
\hline $27-1100$ & $08-10-88$ & 1630 & 130 & $<6$ & 11 & 10 & $<4$ & .044 \\
\hline $27-1101$ & $08-17-88$ & 1215 & 41 & $<6$ & $<3$ & $<10$ & $<4$ & .020 \\
\hline $27-1101$ & $08-17-88$ & 1215 & 41 & $<6$ & $<3$ & $<10$ & $<4$ & .020 \\
\hline $27-1101$ & $08-17-88$ & 1300 & 41 & $<6$ & $<3$ & $<10$ & $<4$ & .019 \\
\hline $27-1101$ & $08-17-88$ & 1300 & 41 & $<6$ & $<3$ & $<10$ & $<4$ & .019 \\
\hline $27-1121$ & $08-23-88$ & 1030 & 38 & $<6$ & 4 & $<10$ & $<4$ & .022 \\
\hline $27-1124$ & $10-26-89$ & 1500 & 95 & $<6$ & 3 & $<10$ & $<4$ & .070 \\
\hline $27-1164$ & $05-02-90$ & 1400 & 74 & $<6$ & 70 & $<10$ & $<4$ & .010 \\
\hline $27-1165$ & $10-31-89$ & 1600 & 35 & $<6$ & 15 & $<10$ & $<4$ & .030 \\
\hline $27-1167$ & $08-30-89$ & 1655 & 41 & $<6$ & $<3$ & $<10$ & 5 & .020 \\
\hline $27-1169$ & $08-30-89$ & 1410 & 28 & $<6$ & 4 & 20 & $<4$ & .010 \\
\hline $27-1172$ & $08-31-89$ & 1400 & 34 & $<6$ & 6 & 10 & $<4$ & .020 \\
\hline $27-1176$ & $08-31-89$ & 1010 & 4 & $<6$ & $<3$ & 20 & $<4$ & $<.010$ \\
\hline $27-1177$ & $08-22-89$ & 0935 & 65 & $<6$ & $<3$ & $<10$ & $<4$ & .080 \\
\hline $27-1177$ & $08-22-89$ & 0935 & 65 & $<6$ & $<3$ & $<10$ & $<4$ & .080 \\
\hline $27-1177$ & $08-22-89$ & 0955 & 66 & $<6$ & 9 & $<10$ & $<4$ & .090 \\
\hline $27-1177$ & $08-22-89$ & 0955 & 66 & $<6$ & 9 & $<10$ & $<4$ & .090 \\
\hline $27-1180$ & $08-21-89$ & 1250 & 72 & $<6$ & 10 & $<10$ & $<4$ & .11 \\
\hline $27-1181$ & 08-23-89 & 0925 & 90 & $<6$ & 8 & $<10$ & $<4$ & .070 \\
\hline $27-1182$ & $08-25-89$ & 0920 & 43 & $<6$ & 43 & $<10$ & $<4$ & .020 \\
\hline $27-1183$ & $10-27-89$ & 1200 & 81 & $<6$ & $<3$ & $<10$ & 4 & .040 \\
\hline $27-1184$ & 08-23-89 & 1530 & 60 & $<6$ & 9 & $<10$ & $<4$ & .020 \\
\hline $27-1185$ & $08-24-89$ & 1705 & 69 & $<6$ & 5 & $<10$ & $<4$ & .030 \\
\hline $27-1187$ & $08-2489$ & 1355 & 54 & $<6$ & 6 & $<10$ & $<4$ & .020 \\
\hline $27-1188$ & $08-2489$ & 0910 & 100 & $<6$ & 12 & $<10$ & $<4$ & .030 \\
\hline $27-1170$ & $11-03-89$ & 1400 & 5 & $<6$ & 27 & $<10$ & $<4$ & .010 \\
\hline $27-1174$ & $10-31-89$ & 1200 & 140 & $<6$ & 37 & $<10$ & $<4$ & .040 \\
\hline $27-1186$ & $10-25-89$ & 1330 & 69 & $<6$ & 38 & 60 & $<4$ & .030 \\
\hline $19-0237$ & $08-25-88$ & 1745 & 41 & $<6$ & $<3$ & $<10$ & 7 & .019 \\
\hline $19-0252$ & $11-06-89$ & 1615 & 400 & $<6$ & 8 & $<10$ & 7 & .020 \\
\hline $19-0254$ & $11-01-89$ & 1330 & 52 & $<6$ & $<3$ & $<10$ & $<4$ & .010 \\
\hline $19-0256$ & $11-02-89$ & 1330 & 38 & $<6$ & 14 & $<10$ & $<4$ & .010 \\
\hline $19-0284$ & $08-26-88$ & 1315 & 47 & $<6$ & 9 & $<10$ & 5 & .014 \\
\hline $27-1090$ & $08-09-88$ & 1330 & 30 & $<6$ & $<3$ & 10 & 5 & $<.010$ \\
\hline $27-1092$ & $08-12-88$ & 1225 & 48 & $<6$ & $<3$ & $<10$ & 4 & .046 \\
\hline $27-1093$ & $08-12-88$ & 1000 & 30 & $<6$ & $<3$ & 10 & 4 & .040 \\
\hline $27-1099$ & $08-09-88$ & 0915 & 22 & $<6$ & $<3$ & $<10$ & $<4$ & .012 \\
\hline
\end{tabular}


Appendix 2. Results of water-quality anaivses of ground-water and surface-water samples from the New Jersey Highlands study area-Continued

\begin{tabular}{|c|c|c|c|c|c|c|c|}
\hline $\begin{array}{c}\text { New } \\
\text { Jersey } \\
\text { well } \\
\text { number }\end{array}$ & Date & Time & $\begin{array}{c}\text { Tritium, } \\
\text { total } \\
\text { (pCi/L) }\end{array}$ & $\begin{array}{c}\text { Tritium, } \\
2 \text { sigma, } \\
\text { error, } \\
\text { water, whole } \\
\text { total } \\
\text { (pCi/L) }\end{array}$ & $\begin{array}{c}\mathrm{H}-2 / \mathrm{H}-1 \\
\text { stable } \\
\text { isotope } \\
\text { ratio } \\
\text { (per mil) }\end{array}$ & $\begin{array}{c}\text { O-18/O-16 } \\
\text { stable } \\
\text { isotope } \\
\text { ratio } \\
\text { (per mil) }\end{array}$ & $\begin{array}{c}\text { Sulfate } \\
\text { water } \\
\text { dissolved } \\
\text { uncorrected } \\
(\mathrm{mg} / \mathrm{L})\end{array}$ \\
\hline $19-0255$ & $11-01-89$ & 1030 & -- & -- & -49.5 & -8.10 & $<1.0$ \\
\hline $27-1089$ & $08-10-88$ & 1230 & -- & -- & -48.5 & -8.05 & -- \\
\hline $27-1091$ & $08-11-88$ & 1330 & -- & -- & -48.5 & -7.85 & -- \\
\hline $27-1094$ & 08-09-88 & 1600 & $-\cdot$ & -- & -- & -- & - \\
\hline $27-1095$ & 08-09-88 & 1450 & -. & -- & -- & -- & -- \\
\hline $27-1096$ & 08-08-88 & 1715 & -- & -- & -- & -- & -- \\
\hline $27-1097$ & 08-08-88 & 1630 & -- & -- & -- & - & -- \\
\hline $27-1098$ & 08-11-88 & 0945 & -- & -- & -49.5 & -8.05 & -- \\
\hline $27-1100$ & $08-10-88$ & 1630 & -. & -. & -- & -- & -- \\
\hline $27-1101$ & $08-17-88$ & 1215 & -- & -- & -47.0 & -8.00 & -- \\
\hline $27-1101$ & $08-17-88$ & 1215 & -- & -- & -47.0 & -8.00 & -- \\
\hline $27-1101$ & 08-17-88 & 1300 & -- & -- & -46.0 & -7.95 & -- \\
\hline $27-1101$ & $08-17-88$ & 1300 & -- & -- & -46.0 & -7.95 & -- \\
\hline $27-1121$ & $08-23-88$ & 1030 & -- & -- & -48.0 & -8.25 & -- \\
\hline $27-1124$ & $10-26-89$ & 1500 & 97 & 9.0 & -43.0 & -6.85 & $<1.0$ \\
\hline $27-1164$ & $05-02-90$ & 1400 & $<5.7$ & 3.2 & -48.5 & -8.20 & -- \\
\hline $27-1165$ & $10-31-89$ & 1600 & 72 & 7.7 & -48.5 & -8.10 & $<1.0$ \\
\hline $27-1167$ & 08-30-89 & 1655 & 88 & 8.3 & -50.0 & -7.80 & $<1.0$ \\
\hline $27-1169$ & $08-30-89$ & 1410 & 45 & 5.8 & -49.0 & -8.05 & $<1.0$ \\
\hline $27-1172$ & $08-31-89$ & 1400 & 63 & 7.0 & -51.5 & -8.10 & $<1.0$ \\
\hline $27-1176$ & $08-31-89$ & 1010 & -- & -- & -53.0 & -8.40 & $<1.0$ \\
\hline $27-1177$ & $08-22-89$ & 0935 & 60 & 7.0 & -48.0 & -7.65 & $<1.0$ \\
\hline $27-1177$ & $08-22-89$ & 0935 & 60 & 7.0 & -48.0 & -7.65 & $<1.0$ \\
\hline $27-1177$ & $08-22-89$ & 0955 & -- & -- & -47.0 & -7.65 & $<1.0$ \\
\hline $27-1177$ & $08-22-89$ & 0955 & -. & -- & -47.0 & -7.65 & $<1.0$ \\
\hline $27-1180$ & $08-21-89$ & 1250 & 63 & 7.0 & -47.0 & -7.85 & $<1.0$ \\
\hline $27-1181$ & $08-23-89$ & 0925 & 64 & 7.0 & -48.5 & -8.05 & $<1.0$ \\
\hline $27-1182$ & 08-25-89 & 0920 & -- & -- & -51.5 & -8.20 & $<1.0$ \\
\hline $27-1183$ & $10-27-89$ & 1200 & 60 & 7.0 & -40.5 & -6.25 & $<1.0$ \\
\hline $27-1184$ & 08-23-89 & 1530 & -- & -- & -48.5 & -7.85 & $<1.0$ \\
\hline $27-1185$ & $08-24-89$ & 1705 & 83 & 9.0 & -48.0 & -7.95 & $<1.0$ \\
\hline $27-1187$ & $08-24-89$ & 1355 & 46 & 6.4 & -50.0 & -8.35 & $<1.0$ \\
\hline $27-1188$ & $08-24-89$ & 0910 & 50 & 6.4 & -44.4 & -7.70 & $<1.0$ \\
\hline $27-1170$ & 11-03-89 & 1400 & -- & -- & -50.5 & -8.40 & $<1.0$ \\
\hline $27-1174$ & $10-31-89$ & 1200 & -- & -- & -48.0 & -7.80 & $<1.0$ \\
\hline $27-1186$ & $10-25-89$ & 1330 & -- & -. & -44.5 & -7.20 & $<1.0$ \\
\hline $19-0237$ & $08-25-88$ & 1745 & -- & -- & -- & -- & -- \\
\hline $19-0252$ & $11-06-89$ & 1615 & 72 & 7.7 & -47.5 & -7.90 & $<1.0$ \\
\hline $19-0254$ & $11-01-89$ & 1330 & -- & -- & -46.0 & -7.75 & $<1.0$ \\
\hline $19-0256$ & $11-02-89$ & 1330 & 57 & 6.4 & -44.5 & -7.45 & $<1.0$ \\
\hline $19-0284$ & $08-26-88$ & 1315 & -- & -- & -- & -- & -- \\
\hline $27-1090$ & $08-09-88$ & 1330 & -- & -- & -- & -- & -- \\
\hline $27-1092$ & $08-12-88$ & 1225 & -- & -- & -- & -- & -- \\
\hline $27-1093$ & $08-12-88$ & 1000 & -- & -- & -- & -- & -- \\
\hline 27-1099 & $08-09-88$ & 0915 & -- & -- & -- & -- & -- \\
\hline
\end{tabular}


Appendix 2. Results of water-quality analyses of ground-water and surface-water samples from the New Jersey Highlands study area-Continued

\begin{tabular}{|c|c|c|c|c|c|c|c|}
\hline $\begin{array}{c}\text { New } \\
\text { Jersey } \\
\text { well } \\
\text { number }\end{array}$ & $\begin{array}{l}\text { Aquifer } \\
\text { code }\end{array}$ & $\begin{array}{l}\text { Station } \\
\text { number }\end{array}$ & Local identifier & Date & Time & $\begin{array}{c}\text { Temper- } \\
\text { ature of } \\
\text { water } \\
\text { (deg C) }\end{array}$ & $\begin{array}{c}\text { Oxygen, } \\
\text { dissolved } \\
(\mathrm{mg} / \mathrm{L})\end{array}$ \\
\hline $27-1099$ & 374LSVL & 405205074380901 & JAMES SMITH 1 & $08-09-88$ & 0915 & 13.0 & 6.8 \\
\hline $27-1099$ & 374LSVL & 405205074380901 & JAMES SMITH 1 & $08-09-88$ & 1030 & 13.0 & 6.8 \\
\hline $27-1099$ & 374LSVL & 405205074380901 & JAMES SMITH 1 & $08-09-88$ & 1030 & 13.0 & 6.8 \\
\hline $27-1102$ & 374LSVL & 405010074414401 & BAIETTO 1 & $08-17-88$ & 1530 & 11.5 & 5.6 \\
\hline $27-1105$ & 374LSVL & 404807074445601 & MCCORMACK 1 & $08-18-88$ & 1430 & 11.5 & 9.1 \\
\hline $27-1106$ & 374LSVL & 404831074433801 & W MORRIS CENTRAL HS 1 & $08-24-88$ & 1400 & 12.5 & 1.2 \\
\hline $27-1107$ & 374LSVL & 404757074445201 & PACZKOWSKI 1 & $08-18-88$ & 1200 & 12.0 & 9.8 \\
\hline $27-1108$ & 374LSVL & 404746074444601 & NAUGHRIGHT 1 & $08-18-88$ & 0935 & 11.5 & 7.2 \\
\hline $27-1118$ & 374LSVL & 404811074451501 & LYNCH 1 & $08-22-88$ & 1345 & 12.0 & -- \\
\hline $27-1118$ & 374LSVL & 404811074451501 & LYNCH 1 & $08-22-88$ & 1345 & 12.0 & -- \\
\hline $27-1118$ & 374LSVL & 404811074451501 & LYNCH 1 & $11-02-89$ & 1000 & 11.5 & 8.0 \\
\hline $27-1118$ & 374LSVL & 404811074451501 & LYNCH 1 & $11-02-89$ & 1000 & 11.5 & 8.0 \\
\hline $27-1119$ & 374LSVL & 404725074452101 & LONG VALLEY PRESB CH & $08-25-88$ & 1030 & 11.0 & 10.6 \\
\hline $27-1122$ & 374LSVL & 404548074491901 & VANCE 1 & $08-23-88$ & 1515 & 12.5 & -- \\
\hline $27-1123$ & 374LSVL & 405330074363801 & KENVIL NEWCRETE 1 OBS & $10-25-89$ & 1600 & 11.0 & 2.6 \\
\hline $27-1125$ & 374LSVL & 404934074385901 & BLACK RIVER 3 OBS & $02-27-90$ & 1750 & 11.0 & 5.8 \\
\hline $27-1126$ & 374LSVL & 404809074415501 & BLACK RIVER 4 OBS & $05-02-90$ & 1620 & 11.0 & 7.9 \\
\hline $27-1156$ & 374LSVL & 404624074480301 & ODOWD DOM & $10-27-89$ & 1000 & 10.5 & 3.7 \\
\hline $27-1157$ & 374LSVL & 404625074474401 & RYAN DOM WELL & $10-24-89$ & 1300 & 11.0 & 8.0 \\
\hline $27-1158$ & 374LSVL & 404626074474501 & RYAN 2 SPRING & $10-24-89$ & 1030 & 11.5 & 3.8 \\
\hline $27-1158$ & 374LSVL & 404626074474501 & RYAN 2 SPRING & $10-24-89$ & 1030 & 11.5 & 3.8 \\
\hline $27-1158$ & 374LSVL & 404626074474501 & RYAN 2 SPRING & $10-24-89$ & 1040 & 11.5 & 3.8 \\
\hline $27-1158$ & 374LSVL & 404626074474501 & RYAN 2 SPRING & $10-24-89$ & 1040 & 11.5 & 3.8 \\
\hline $27-1160$ & 374LSVL & 404717074463801 & WELSH FARMS 1 & 09-01-89 & 0950 & 12.5 & 5.8 \\
\hline $27-1160$ & 374LSVL & 404717074463801 & WELSH FARMS 1 & 09-01-89 & 0950 & 12.5 & 5.8 \\
\hline $27-1160$ & 374LSVL & 404717074463801 & WELSH FARMS 1 & 09-01-89 & 0955 & -- & 5.8 \\
\hline $27-1160$ & 374LSVL & 404717074463801 & WELSH FARMS 1 & $09-01-89$ & 0955 & -- & 5.8 \\
\hline $27-1163$ & 374LSVL & 404805074451601 & COLLING DOM & $08-29-89$ & 1615 & 12.5 & 9.7 \\
\hline $27-1166$ & 374LSVL & 404823074442001 & ZAIKOWSKI DOM & $11-01-89$ & 1700 & 10.5 & 6.2 \\
\hline $27-1168$ & 374LSVL & 404949074414501 & MARVELAND FARMS & 09-06-89 & 1025 & 12.0 & 1.7 \\
\hline $27-1173$ & 374LSVL & 40510807.4411001 & RWC PW7-PLEASANT VILL 1 & 09-06-89 & 1220 & 10.0 & 10.6 \\
\hline $27-1175$ & 374LSVL & 405137074375001 & NORTH JERSEY DEV COM & $10-31-89$ & 1000 & 11.0 & 7.4 \\
\hline $27-1322$ & 374LSVL & 405107074383501 & RWC IAT & 11-03-89 & 1030 & 11.0 & 4.8 \\
\hline $19-0010$ & 400PCMB & 404416074464501 & SPRING VALLEY1 & $11-23-88$ & 1145 & 11.5 & .3 \\
\hline $19-0010$ & 400PCMB & 404416074464501 & SPRING VALLEY1 & $10-30-89$ & 1300 & 12.0 & .5 \\
\hline $19-0236$ & 400PCMB & 404432074515601 & MILLER 1 & $08-26-88$ & 0845 & 11.0 & 5.2 \\
\hline $19-0236$ & 400PCMB & 404432074515601 & MILLER 1 & $08-26-88$ & 0845 & 11.0 & 5.2 \\
\hline $19-0236$ & 400РCMB & 404432074515601 & MILLER 1 & $08-26-88$ & 1000 & 11.0 & 5.2 \\
\hline $19-0236$ & 400РCMB & 404432074515601 & MILLER 1 & $08-26-88$ & 1000 & 11.0 & 5.2 \\
\hline $19-0236$ & 400РCMB & 404432074515601 & MILLER 1 & 09-29-89 & 1400 & 10.5 & 5.5 \\
\hline $19-0236$ & 400PCMB & 404432074515601 & MILLER 1 & $09-29-89$ & 1400 & 10.5 & 5.5 \\
\hline $19-0238$ & 400PCMB & $40442307447520 \mathrm{I}$ & SEICKEL 1 & $08-25-88$ & 1430 & 11.0 & 8.7 \\
\hline $19-0245$ & 400PCMB & 404244074515001 & CALIFON 2 & $11-22-88$ & 1145 & 10.5 & 7.5 \\
\hline $19-0245$ & 400РCMB & 404244074515001 & CALIFON 2 & $10-30-89$ & 1600 & 10.5 & 9.8 \\
\hline $19-0253$ & 400РCMB & 404314074511001 & BATSON 234 RT 513 & $11-06-89$ & 1150 & 10.5 & 9.4 \\
\hline
\end{tabular}


Appendix 2. Results of water-quality analyses of ground-water and surface-water samples from the New Jersey Highlands study area-Continued

\begin{tabular}{|c|c|c|c|c|c|c|c|c|}
\hline $\begin{array}{c}\text { New } \\
\text { Jersey } \\
\text { well } \\
\text { number }\end{array}$ & Date & Time & $\begin{array}{c}\text { Specific } \\
\text { conductance } \\
\text { field } \\
(\mu \mathrm{S} / \mathrm{cm})\end{array}$ & $\begin{array}{c}\text { Specific } \\
\text { conductance } \\
\text { lab } \\
(\mu \mathrm{S} / \mathrm{cm})\end{array}$ & $\begin{array}{l}\text { Nitrogen, } \\
\text { ammonia } \\
\text { dissolved } \\
\text { (mg/L as } \\
\mathrm{N})\end{array}$ & $\begin{array}{l}\text { Nitrogen, } \\
\text { nitrite } \\
\text { dissolved } \\
\text { (mg/L as } \\
\mathrm{N} \text { ) }\end{array}$ & $\begin{array}{c}\text { Nitrogen, } \\
\text { ammonia }+ \\
\text { organic } \\
\text { dissolved } \\
(\mathrm{mg} / \mathrm{L} \text { as } \mathrm{N})\end{array}$ & $\begin{array}{c}\text { Nitrogen, } \\
\mathrm{NO}_{2}+\mathrm{NO}_{3} \\
\text { dissolved } \\
(\mathrm{mg} / \mathrm{L} \text { as } \mathrm{N})\end{array}$ \\
\hline $27-1099$ & $08-09-88$ & 0915 & 134 & -- & 0.010 & $<0.010$ & 0.90 & 0.740 \\
\hline $27-1099$ & $08-09-88$ & 1030 & 134 & -- & $<.010$ & $<.010$ & 1.5 & .760 \\
\hline $27-1099$ & $08-09-88$ & 1030 & 134 & -- & $<.010$ & $<.010$ & 1.5 & .760 \\
\hline $27-1102$ & $08-17-88$ & 1530 & 178 & -- & $<.010$ & $<.010$ & .20 & 3.70 \\
\hline $27-1105$ & $08-18-88$ & 1430 & 158 & -- & $<.010$ & $<.010$ & .40 & .800 \\
\hline $27-1106$ & $08-24-88$ & 1400 & 269 & -- & $<.010$ & $<.010$ & .40 & .410 \\
\hline $27-1107$ & $08-18-88$ & 1200 & 214 & -- & $<.010$ & $<.010$ & .40 & .630 \\
\hline $27-1108$ & $08-18-88$ & 0935 & 249 & -- & $<.010$ & $<.010$ & .20 & 1.90 \\
\hline $27-1118$ & $08-22-88$ & 1345 & 199 & -- & $<.010$ & $<.010$ & .20 & 2.20 \\
\hline $27-1118$ & $08-22-88$ & 1345 & 199 & -- & $<.010$ & $<.010$ & .20 & 2.20 \\
\hline $27-1118$ & $11-02-89$ & 1000 & 216 & 209 & $<.010$ & $<.010$ & .60 & 2.40 \\
\hline $27-1118$ & $11-02-89$ & 1000 & 216 & 209 & $<.010$ & $<.010$ & .60 & 2.40 \\
\hline 27-1119- & $08-25-88$ & 1030 & 201 & -- & $<.010$ & $<.010$ & .60 & 1.30 \\
\hline $27-1122$ & $08-23-88$ & 1515 & 139 & -- & $<.010$ & $<.010$ & $<.20$ & .350 \\
\hline $27-1123$ & $10-25-89$ & 1600 & 150 & 148 & $<.010$ & $<.010$ & $<.20$ & .230 \\
\hline $27-1125$ & $02-27-90$ & 1750 & 140 & 151 & $<.010$ & $<.010$ & $<.20$ & .300 \\
\hline $27-1126$ & $05-02-90$ & 1620 & 150 & 147 & $<.010$ & $<.010$ & $<.20$ & 1.00 \\
\hline $27-1156$ & $10-27-89$ & 1000 & 343 & 349 & $<.010$ & $<.010$ & $<.20$ & 1.70 \\
\hline $27-1157$ & $10-24-89$ & 1300 & 545 & 565 & $<.010$ & $<.010$ & .40 & 8.10 \\
\hline $27-1158$ & $10-24-89$ & 1030 & 692 & 695 & .030 & .010 & .60 & 9.50 \\
\hline $27-1158$ & $10-24-89$ & 1030 & 692 & 695 & .030 & .010 & .60 & 9.50 \\
\hline $27-1158$ & $10-24-89$ & 1040 & 692 & 696 & .020 & .010 & .60 & 9.90 \\
\hline $27-1158$ & $10-24-89$ & 1040 & 692 & 696 & .020 & .010 & .60 & 9.90 \\
\hline $27-1160$ & $09-01-89$ & 0950 & 445 & 437 & $<.010$ & $<.010$ & .20 & 2.10 \\
\hline $27-1160$ & 09-01-89 & 0950 & 445 & 437 & $<.010$ & $<.010$ & .20 & 2.10 \\
\hline $27-1160$ & $09-01-89$ & 0955 & 445 & 441 & $<.010$ & $<.010$ & .70 & 2.10 \\
\hline $27-1160$ & $09-01-89$ & 0955 & 445 & 441 & $<.010$ & $<.010$ & .70 & 2.10 \\
\hline $27-1163$ & $08-29-89$ & 1615 & 178 & 183 & $<.010$ & $<.010$ & .60 & 1.50 \\
\hline $27-1166$ & $11-01-89$ & 1700 & 248 & 246 & $<.010$ & $<.010$ & .40 & 1.90 \\
\hline $27-1168$ & $09-06-89$ & 1025 & 253 & 265 & .010 & $<.010$ & .20 & 4.00 \\
\hline $27-1173$ & $09-06-89$ & 1220 & 176 & 180 & .020 & $<.010$ & $<.20$ & .850 \\
\hline $27-1175$ & $10-31-89$ & 1000 & 199 & 195 & $<.010$ & $<.010$ & .30 & .810 \\
\hline $27-1322$ & 11-03-89 & 1030 & 147 & 75 & $<.010$ & $<.010$ & $<.20$ & .650 \\
\hline $19-0010$ & $11-23-88$ & 1145 & 226 & 228 & $<.010$ & $<.010$ & .30 & .220 \\
\hline $19-0010$ & $10-30-89$ & 1300 & 259 & 254 & $<.010$ & $<.010$ & $<.20$ & .270 \\
\hline $19-0236$ & $08-26-88$ & 0845 & 103 & -- & $<.010$ & $<.010$ & .40 & .770 \\
\hline $19-0236$ & $08-26-88$ & 0845 & 103 & -- & $<.010$ & $<.010$ & .40 & .770 \\
\hline $19-0236$ & $08-26-88$ & 1000 & 103 & -- & $<.010$ & $<.010$ & .40 & .750 \\
\hline $19-0236$ & $08-26-88$ & 1000 & 103 & -- & $<.010$ & $<.010$ & .40 & .750 \\
\hline $19-0236$ & $09-29-89$ & 1400 & 94 & 102 & $<.010$ & $<.010$ & .60 & .760 \\
\hline $19-0236$ & 09-29-89 & 1400 & 94 & 102 & $<.010$ & $<.010$ & .60 & .760 \\
\hline $19-0238$ & $08-25-88$ & 1430 & 64 & -- & $<.010$ & $<.010$ & .20 & .130 \\
\hline $19-0245$ & $11-22-88$ & 1145 & 212 & 201 & $<.010$ & .020 & $<.20$ & 2.30 \\
\hline $19-0245$ & $10-30-89$ & 1600 & 199 & 193 & $<.010$ & $<.010$ & .80 & 2.00 \\
\hline $19-0253$ & $11-06-89$ & 1150 & 107 & 100 & .030 & $<.010$ & .30 & 1.60 \\
\hline
\end{tabular}


Appendix 2. Results of water-quality analyses of ground-water and surface-water samples from the New Jersey Hiahlands study area--Continued

\begin{tabular}{|c|c|c|c|c|c|c|c|c|}
\hline $\begin{array}{l}\text { New } \\
\text { Jersey } \\
\text { well } \\
\text { number }\end{array}$ & Date & Time & $\begin{array}{c}\mathrm{pH} \\
\text { (standard } \\
\text { units) }\end{array}$ & $\begin{array}{c}\mathrm{pH} \\
\text { lab } \\
\text { (standard } \\
\text { units) }\end{array}$ & $\begin{array}{c}\text { Alkalinity, } \\
\text { field } \\
(\mathrm{mg} / \mathrm{L} \text { as } \\
\left.\mathrm{CaCO}_{3}\right)\end{array}$ & $\begin{array}{c}\text { Alkalinity, } \\
\text { lab } \\
\left(\mathrm{mg}^{\prime} / \mathrm{L} \text { as }\right. \\
\left.\mathrm{CaCO}_{3}\right)\end{array}$ & $\begin{array}{l}\text { Phosphorus } \\
\text { ortho, } \\
\text { dissolved } \\
\text { (mg/L as } \mathrm{P} \text { ) }\end{array}$ & $\begin{array}{c}\text { Carbon } \\
\text { organic, } \\
\text { dissolved } \\
(\mathrm{mg} / \mathrm{L} \text { as } \mathrm{C})\end{array}$ \\
\hline $27-1099$ & 08-09-88 & 0915 & 8.4 & -- & 61 & 64 & 0.010 & 2.4 \\
\hline $27-1099$ & 08-09-88 & 1030 & 8.4 & -- & 61 & 63 & .010 & 1.0 \\
\hline $27-1099$ & 08-09-88 & 1030 & 8.4 & -- & 61 & 63 & .010 & 1.0 \\
\hline $27-1102$ & $08-17-88$ & 1530 & 6.4 & .. & 61 & 51 & $<.010$ & .5 \\
\hline $27-1105$ & $08-18-88$ & 1430 & 8.4 & -- & 72 & 67 & $<.010$ & .3 \\
\hline $27-1106$ & $08-24-88$ & 1400 & 8.1 & -- & 123 & 119 & $<.010$ & .4 \\
\hline $27-1107$ & $08-18-88$ & 1200 & 8.4 & -- & 91 & 80 & $<.010$ & .5 \\
\hline $27-1108$ & $08-18-88$ & 0935 & 8.1 & -- & 102 & 100 & $<.010$ & .6 \\
\hline $27-1118$ & $08-22-88$ & 1345 & 7.2 & -- & 63 & 63 & .010 & .7 \\
\hline $27-1118$ & $08-22-88$ & 1345 & 7.2 & -- & 63 & 63 & .010 & .7 \\
\hline $27-1118$ & $11-02-89$ & 1000 & 7.3 & 7.5 & 69 & 63 & .020 & .4 \\
\hline $27-1118$ & $11-02-89$ & 1000 & 7.3 & 7.5 & 69 & 63 & .020 & .4 \\
\hline 27-1119- & $08-25-88$ & 1030 & 8.3 & -- & 99 & 91 & .020 & .5 \\
\hline $27-1122$ & $08-23-88$ & 1515 & 7.9 & -- & 66 & 63 & .030 & .6 \\
\hline $27-1123$ & $10-25-89$ & 1600 & 8.6 & 8.5 & 75 & 67 & .030 & .3 \\
\hline $27-1125$ & $02-27-90$ & 1750 & 8.8 & 8.7 & 76 & 71 & $<.010$ & .5 \\
\hline $27-1126$ & $05-02-90$ & 1620 & 7.7 & 8.2 & 60 & 64 & .060 & .5 \\
\hline $27-1156$ & I0-27-89 & 1000 & 7.9 & 7.9 & 149 & 146 & $<.010$ & .5 \\
\hline $27-1157$ & $10-24-89$ & 1300 & 7.9 & 8.4 & 163 & 164 & .030 & -- \\
\hline $27-1158$ & $10-24-89$ & 1030 & 7.6 & 7.5 & 225 & 228 & $<.010$ & -- \\
\hline $27-1158$ & $10-24-89$ & 1030 & 7.6 & 7.5 & 225 & 228 & $<.010$ & -- \\
\hline $27-1158$ & $10-24-89$ & 1040 & 7.6 & 7.5 & 225 & 227 & $<010$ & -- \\
\hline $27-1158$ & $10-24-89$ & 1040 & 7.6 & 7.5 & 225 & 227 & $<.010$ & -- \\
\hline $27-1160$ & $09-01-89$ & 0950 & 7.6 & 7.8 & 162 & 163 & $<.010$ & .4 \\
\hline $27-1160$ & 09-01-89 & 0950 & 7.6 & 7.8 & 162 & 163 & $<.010$ & .4 \\
\hline $27-1160$ & $09-01-89$ & 0955 & 7.6 & 7.7 & 162 & 163 & $<.010$ & .4 \\
\hline $27-1160$ & $09-01-89$ & 0955 & 7.6 & 7.7 & 162 & 163 & $<.010$ & .4 \\
\hline $27-1163$ & $08-29-89$ & 1615 & 7.6 & 7.9 & 85 & 87 & .010 & .3 \\
\hline $27-1166$ & $11-01-89$ & 1700 & 8.3 & 8.1 & 85 & 95 & .010 & .2 \\
\hline $27-1168$ & $09-06-89$ & 1025 & 5.7 & 6.1 & 28 & 28 & $<.010$ & .4 \\
\hline $27-1173$ & $09-06-89$ & 1220 & 7.3 & 7.7 & 74 & 74 & .020 & .2 \\
\hline $27-1175$ & $10-31-89$ & 1000 & 7.9 & 8.1 & 69 & 65 & .020 & .2 \\
\hline $27-1322$ & $11-03-89$ & 1030 & 8.4 & 6.7 & -- & 26 & .020 & .4 \\
\hline $19-0010$ & $11-23-88$ & 1145 & 6.8 & 7.2 & 71 & 60 & $<.010$ & .4 \\
\hline $19-0010$ & $10-30-89$ & 1300 & 6.9 & 7.0 & 66 & 61 & $<.010$ & .6 \\
\hline $19-0236$ & $08-26-88$ & 0845 & 6.5 & -- & 25 & 23 & .040 & .3 \\
\hline $19-0236$ & $08-26-88$ & 0845 & 6.5 & -- & 25 & 23 & .040 & .3 \\
\hline $19-0236$ & $08-26-88$ & 1000 & 6.5 & -- & 25 & 24 & .040 & .9 \\
\hline $19-0236$ & $08-26-88$ & 1000 & 6.5 & -- & 25 & 24 & .040 & .9 \\
\hline $19-0236$ & 09-29-89 & 1400 & 6.3 & 6.5 & 27 & 24 & $.04 \dot{0}$ & .3 \\
\hline $19-0236$ & $09-29-89$ & 1400 & 6.3 & 6.5 & 27 & 24 & .040 & .3 \\
\hline $19-0238$ & $08-25-88$ & 1430 & 5.8 & -- & 17 & 16 & .020 & .6 \\
\hline $19-0245$ & $11-22-88$ & 1145 & 6.5 & 6.8 & 40 & 38 & .030 & .3 \\
\hline $19-0245$ & $10-30-89$ & 1600 & 6.6 & 6.7 & -- & 36 & .020 & .4 \\
\hline $19-0253$ & $11-06-89$ & 1150 & 6.5 & 6.4 & 22 & 23 & .180 & .5 \\
\hline
\end{tabular}


Appendix 2. Results of water-quality analyses of ground-water and surface-water samples from the New Jersey Highlands study area-Continued

\begin{tabular}{|c|c|c|c|c|c|c|c|c|c|}
\hline $\begin{array}{c}\text { New } \\
\text { Jersey } \\
\text { well } \\
\text { number }\end{array}$ & Date & Time & $\begin{array}{c}\text { Calcium, } \\
\text { dissolved } \\
(\mathrm{mg} / \mathrm{L} \\
\text { as Ca) }\end{array}$ & $\begin{array}{l}\text { Magnesium, } \\
\text { dissolved } \\
\text { (mg/L } / \mathrm{L} \\
\text { as } \mathrm{Mg})\end{array}$ & $\begin{array}{c}\text { Sodium, } \\
\text { dissolved } \\
(\mathrm{mg} / \mathrm{L} \\
\text { as } \mathrm{Na})\end{array}$ & $\begin{array}{c}\text { Potassium, } \\
\text { dissolved } \\
(\mathrm{mg} / \mathrm{L} \\
\text { as } \mathrm{K})\end{array}$ & $\begin{array}{c}\text { Chloride, } \\
\text { dissolved } \\
(\mathrm{mg} / \mathrm{L} \\
\text { as Cl) }\end{array}$ & $\begin{array}{c}\text { Sulfate, } \\
\text { dissolved } \\
(\mathrm{mg} / \mathrm{L} \\
\left.\text { as } \mathrm{So}_{4}\right)\end{array}$ & $\begin{array}{c}\text { Fluoride, } \\
\text { dissolved } \\
\text { (mg/L } \\
\text { as F) }\end{array}$ \\
\hline 27-1099 & $08-09-88$ & 0915 & 14 & 6.9 & 3.0 & 0.40 & 1.2 & 0.70 & 0.10 \\
\hline $27-1099$ & $08-09-88$ & 1030 & 14 & 7.0 & 3.1 & .40 & 1.2 & 2.1 & .10 \\
\hline $27-1099$ & 08-09-88 & 1030 & 14 & 7.0 & 3.1 & .40 & 1.2 & 2.1 & .10 \\
\hline $27-1102$ & $08-17-88$ & 1530 & 15 & 8.4 & 4.8 & 1.1 & 10 & 3.2 & $<.10$ \\
\hline $27-1105$ & 08-18-88 & 1430 & 15 & 9.2 & 2.9 & .70 & 2.9 & 4.4 & .10 \\
\hline $27-1106$ & $08-24-88$ & 1400 & 26 & 17 & 3.7 & .80 & 3.6 & 11 & .10 \\
\hline $27-1107$ & $08-18-88$ & 1200 & 20 & 12 & 2.9 & .80 & 4.2 & 17 & .10 \\
\hline $27-1108$ & $08-18-88$ & 0935 & 23 & 14 & 5.9 & 1.0 & 9.6 & 5.3 & .10 \\
\hline $27-1118$ & $08-22-88$ & 1345 & 18 & 9.1 & 6.7 & .90 & 11 & 10 & .10 \\
\hline $27-1118$ & $08-22-88$ & 1345 & 18 & 9.1 & 6.7 & .90 & 11 & 10 & .10 \\
\hline $27-1118$ & $11-02-89$ & 1000 & 19 & 8.8 & 6.6 & .90 & 12 & 11 & .10 \\
\hline $27-1118$ & $11-02-89$ & 1000 & 19 & 8.8 & 6.6 & .90 & 12 & 11 & .10 \\
\hline 27-1119. & $08-25-88$ & 1030 & 20 & 12 & 2.9 & 1.0 & 2.7 & 4.6 & .10 \\
\hline $27-1122$ & $08-23-88$ & 1515 & 13 & 7.5 & 3.7 & .90 & 1.4 & 4.2 & .10 \\
\hline $27-1123$ & $10-25-89$ & 1600 & 14 & 5.9 & 6.9 & .80 & 3.2 & 3.0 & .10 \\
\hline $27-1125$ & $02-27-90$ & 1750 & 12 & 8.5 & 4.8 & 1.0 & 1.7 & 2.9 & .10 \\
\hline $27-1126$ & $05-02-90$ & 1620 & 12 & 7.0 & 3.1 & .80 & 2.0 & 2.7 & $<.10$ \\
\hline $27-1156$ & $10-27-89$ & 1000 & 35 & 21 & 3.6 & 1.4 & 7.6 & 15 & .10 \\
\hline $27-1157$ & $10-24-89$ & 1300 & 46 & 29 & 21 & 3.6 & 44 & 21 & .10 \\
\hline $27-1158$ & $10-24-89$ & 1030 & 60 & 35 & 23 & 11 & 45 & 22 & .10 \\
\hline $27-1158$ & $10-24-89$ & 1030 & 60 & 35 & 23 & 11 & 45 & 22 & .10 \\
\hline $27-1158$ & $10-24-89$ & 1040 & 61 & 35 & 23 & 11 & 47 & 23 & .10 \\
\hline $27-1158$ & $10-24-89$ & 1040 & 61 & 35 & 23 & 11 & 47 & 23 & .10 \\
\hline $27-1160$ & $09-01-89$ & 0950 & 42 & 24 & 14 & 1.5 & 31 & 16 & .10 \\
\hline $27-1160$ & $09-01-89$ & 0950 & 42 & 24 & 14 & 1.5 & 31 & 16 & .10 \\
\hline $27-1160$ & 09-01-89 & 0955 & 42 & 23 & 14 & 1.6 & 31 & 16 & .10 \\
\hline $27-1160$ & $09-01-89$ & 0955 & 42 & 23 & 14 & 1.6 & 31 & 16 & .10 \\
\hline $27-1163$ & $08-29-89$ & 1615 & 18 & 9.6 & 4.9 & .70 & 1.9 & $<1.0$ & .10 \\
\hline $27-1166$ & $11-01-89$ & 1700 & 23 & 13 & 5.1 & .60 & 11 & 6.0 & $<.10$ \\
\hline $27-1168$ & 09-06-89 & 1025 & 22 & 8.9 & 11 & 2.0 & 34 & 23 & $<.10$ \\
\hline $27-1173$ & 09-06-89 & 1220 & 17 & 8.9 & 4.4 & .60 & 7.5 & 3.0 & .10 \\
\hline $27-1175$ & $10-31-89$ & 1000 & 16 & 9.3 & 6.3 & .70 & 15 & 2.0 & .10 \\
\hline $27-1322$ & $11-03-89$ & 1030 & 6.1 & 1.8 & 5.7 & .50 & 1.7 & 6.0 & $<.10$ \\
\hline $19-0010$ & $11-23-88$ & 1145 & 26 & 5.7 & 10 & .70 & 14 & 38 & .20 \\
\hline $19-0010$ & $10-30-89$ & 1300 & 29 & 6.1 & 11 & .70 & 19 & 28 & .20 \\
\hline $19-0236$ & $08-26-88$ & 0845 & 8.0 & 2.7 & 6.1 & .80 & 5.1 & 13 & .10 \\
\hline $19-0236$ & $08-26-88$ & 0845 & 8.0 & 2.7 & 6.1 & .80 & 5.1 & 13 & .10 \\
\hline $19-0236$ & $08-26-88$ & 1000 & 7.9 & 2.6 & 6.3 & .70 & 3.8 & 13 & .10 \\
\hline $19-0236$ & $08-26-88$ & 1000 & 7.9 & 2.6 & 6.3 & .70 & 3.8 & 13 & .10 \\
\hline $19-0236$ & $09-29-89$ & 1400 & 8.4 & 2.5 & 6.7 & .80 & 5.0 & 13 & .10 \\
\hline $19-0236$ & 09-29-89 & 1400 & 8.4 & 2.5 & 6.7 & .80 & 5.0 & 13 & .10 \\
\hline $19-0238$ & $08-25-88$ & 1430 & 4.8 & 1.8 & 3.3 & .50 & 1.8 & 9.6 & .10 \\
\hline $19-0245$ & $11-22-88$ & 1145 & 20 & 6.6 & 7.9 & .90 & 18 & 19 & $<.10$ \\
\hline $19-0245$ & $10-30-89$ & 1600 & 19 & 6.0 & 7.4 & .80 & 18 & 17 & $<.10$ \\
\hline $19-0253$ & $11-06-89$ & 1150 & 9.2 & 3.6 & 3.7 & 1.0 & 2.9 & 13 & .10 \\
\hline
\end{tabular}


Appendix 2. Results of water-quality analyses of ground-water and surface-water samples from the New Jersey Highlands study areq-Continued

\begin{tabular}{|c|c|c|c|c|c|c|c|c|c|}
\hline $\begin{array}{c}\text { New } \\
\text { Jersey } \\
\text { well } \\
\text { number }\end{array}$ & Date & Time & $\begin{array}{c}\text { Silica, } \\
\text { dissolved } \\
(\mathrm{mg} / \mathrm{L} \\
\left.\text { as } \mathrm{SiO}_{2}\right)\end{array}$ & $\begin{array}{c}\text { Arsenic, } \\
\text { dissolved } \\
(\mu \mathrm{g} / \mathrm{L} \\
\text { as As) }\end{array}$ & $\begin{array}{c}\text { Barium, } \\
\text { dissolved } \\
(\mu \mathrm{g} / \mathrm{L} \\
\text { as } \mathrm{Ba})\end{array}$ & $\begin{array}{c}\text { Beryllium, } \\
\text { dissolved } \\
(\mu \mathrm{g} / \mathrm{L} \\
\text { as Be })\end{array}$ & $\begin{array}{c}\text { Cadmium, } \\
\text { dissolved } \\
(\mu \mathrm{g} / \mathrm{L} \\
\text { as Cd })\end{array}$ & $\begin{array}{c}\text { Chromium, } \\
\text { dissolved } \\
(\mu \mathrm{g} / \mathrm{L} \\
\text { as } \mathrm{Cr})\end{array}$ & $\begin{array}{c}\text { Cobalt, } \\
\text { dissolved } \\
\text { ( } \mu \mathrm{g} / \mathrm{L} \\
\text { as Co) }\end{array}$ \\
\hline $27-1099$ & $08-09-88$ & 0915 & 11 & -- & 4 & $<0.5$ & 1.0 & $<5$ & $<3$ \\
\hline $27-1099$ & 08-09-88 & 1030 & 11 & -- & 4 & $<.5$ & 1.0 & $<5$ & $<3$ \\
\hline 27-1099 & $08-09-88$ & 1030 & 11 & -- & 4 & $<.5$ & 1.0 & $<5$ & $<3$ \\
\hline $27-1102$ & $08-17-88$ & 1530 & 15 & -- & 30 & $<.5$ & $<1.0$ & $<5$ & $<3$ \\
\hline $27-1105$ & $08-18-88$ & 1430 & 14 & -- & 10 & $<.5$ & $<1.0$ & $<5$ & $<3$ \\
\hline $27-1106$ & $08-24-88$ & 1400 & 12 & -- & 20 & $<.5$ & $<1.0$ & $<5$ & $<3$ \\
\hline $27-1107$ & $08-18-88$ & 1200 & 14 & -- & 7 & $<.5$ & $<1.0$ & $<5$ & $<3$ \\
\hline $27-1108$ & $08-18-88$ & 0935 & 16 & -- & 16 & $<.5$ & $<1.0$ & $<5$ & $<3$ \\
\hline $27-1118$ & $08-22-88$ & 1345 & 21 & -- & 9 & $<.5$ & 2.0 & $<5$ & $<3$ \\
\hline 27-II18 & $08-22-88$ & 1345 & 21 & -- & 9 & $<.5$ & 2.0 & $<5$ & $<3$ \\
\hline $27-1118$ & $11-02-89$ & 1000 & 21 & $<1$ & 8 & $<.5$ & $<1.0$ & $<5$ & $<3$ \\
\hline $27-1118$ & $11-02-89$ & 1000 & 21 & $<1$ & 8 & $<.5$ & $<1.0$ & $<5$ & $<3$ \\
\hline 27-1119- & $08-25-88$ & 1030 & 15 & -- & 15 & $<.5$ & $<1.0$ & $<5$ & $<3$ \\
\hline $27-1122$ & $08-23-88$ & 1515 & 17 & -- & 8 & $<.5$ & 2.0 & $<5$ & $<3$ \\
\hline $27-1123$ & $10-25-89$ & 1600 & 14 & $<1$ & 5 & $<.5$ & $<1.0$ & $<5$ & $<3$ \\
\hline $27-1125$ & $02-27-90$ & 1750 & 13 & $<1$ & 9 & $<.5$ & $<1.0$ & $<5$ & $<3$ \\
\hline $27-1126$ & $05-02-90$ & 1620 & 14 & $<1$ & 9 & $<.5$ & $<1.0$ & $<5$ & $<3$ \\
\hline $27-1156$ & $10-27-89$ & 1000 & 11 & $<1$ & 13 & $<.5$ & $<1.0$ & $<5$ & $<3$ \\
\hline $27-1157$ & $10-24-89$ & 1300 & 9.5 & $<1$ & 22 & $<.5$ & $<1.0$ & $<5$ & $<3$ \\
\hline $27-1158$ & $10-24-89$ & 1030 & 9.5 & $<1$ & 33 & $<.5$ & $<1.0$ & $<5$ & $<3$ \\
\hline $27-1158$ & $10-24-89$ & 1030 & 9.5 & $<1$ & 33 & $<.5$ & $<1.0$ & $<5$ & $<3$ \\
\hline $27-1158$ & $10-24-89$ & 1040 & 9.6 & $<1$ & 33 & $<.5$ & $<1.0$ & $<5$ & $<3$ \\
\hline $27-1158$ & $10-24-89$ & 1040 & 9.6 & $<1$ & 33 & $<.5$ & $<1.0$ & $<5$ & $<3$ \\
\hline $27-1160$ & $09-01-89$ & 0950 & 18 & $<1$ & 18 & $<.5$ & $<1.0$ & $<5$ & $<3$ \\
\hline $27-1160$ & $09-0$ I-89 & 0950 & 18 & $<1$ & 18 & $<.5$ & $<1.0$ & $<5$ & $<3$ \\
\hline $27-1160$ & $09-01-89$ & 0955 & 18 & $<1$ & 17 & $<.5$ & $<1.0$ & $<5$ & $<3$ \\
\hline $27-1160$ & $09-01-89$ & 0955 & 18 & $<1$ & 17 & $<.5$ & $<1.0$ & $<5$ & $<3$ \\
\hline $27-1163$ & $08-29-89$ & 1615 & 22 & $<1$ & 11 & $<.5$ & $<1.0$ & $<5$ & $<3$ \\
\hline $27-1166$ & $11-0 I-89$ & 1700 & 14 & $<1$ & 13 & $<.5$ & $<1.0$ & $<5$ & $<3$ \\
\hline $27-1168$ & $09-06-89$ & 1025 & 16 & $<1$ & 110 & $<.5$ & $<1.0$ & $<5$ & $<3$ \\
\hline $27-1173$ & $09-06-89$ & 1220 & 20 & $<$ I & 5 & $<.5$ & $<1.0$ & $<5$ & $<3$ \\
\hline $27-1175$ & $10-31-89$ & 1000 & 16 & $<1$ & 7 & $<.5$ & $<1.0$ & $<5$ & $<3$ \\
\hline $27-1322$ & I1-03-89 & 1030 & 27 & $<1$ & 3 & $<.5$ & $<1.0$ & $<5$ & $<3$ \\
\hline $19-0010$ & $11-23-88$ & 1145 & 22 & $<1$ & -- & -- & $<1.0$ & $<1$ & -. \\
\hline $19-0010$ & $10-30-89$ & 1300 & 22 & $<1$ & $<2$ & $<.5$ & $<1.0$ & $<5$ & $<3$ \\
\hline $19-0236$ & $08-26-88$ & 0845 & 31 & -- & 10 & $<.5$ & $<1.0$ & $<5$ & $<3$ \\
\hline $19-0236$ & $08-26-88$ & 0845 & 31 & -- & 10 & $<.5$ & $<1.0$ & $<5$ & $<3$ \\
\hline $19-0236$ & $08-26-88$ & 1000 & 29 & -- & 10 & $<.5$ & $<1.0$ & $<5$ & $<3$ \\
\hline $19-0236$ & $08-26-88$ & 1000 & 29 & -- & 10 & $<.5$ & $<1.0$ & $<5$ & $<3$ \\
\hline $19-0236$ & $09-29-89$ & 1400 & 29 & $<1$ & -- & -- & $<1.0$ & $<1$ & -- \\
\hline $19-0236$ & $09-29-89$ & 1400 & 29 & $<1$ & -- & -- & $<1.0$ & $<1$ & -- \\
\hline $19-0238$ & $08-25-88$ & 1430 & 19 & .. & 2 & $<.5$ & $<1.0$ & $<5$ & $<3$ \\
\hline $19-0245$ & $11-22-88$ & 1145 & 27 & $<1$ & -- & -- & $<1.0$ & $<1$ & -- \\
\hline $19-0245$ & $10-30-89$ & 1600 & 26 & $<1$ & 12 & $<.5$ & $<1.0$ & $<5$ & $<3$ \\
\hline $19-0253$ & $11-06-89$ & 1150 & 15 & $<1$ & 32 & $<.5$ & $<1.0$ & $<5$ & $<3$ \\
\hline
\end{tabular}


Appendix 2. Results of water-quality analyses of ground-water and surface-water samples from the New Jersey Highlands study area-Continued

\begin{tabular}{|c|c|c|c|c|c|c|c|c|c|}
\hline $\begin{array}{c}\text { New } \\
\text { Jersey } \\
\text { well } \\
\text { number }\end{array}$ & Date & Time & $\begin{array}{l}\text { Copper, } \\
\text { dissolved } \\
(\mu \mathrm{g} / \mathrm{L} \\
\text { as } \mathrm{Cu})\end{array}$ & $\begin{array}{c}\text { Iron, } \\
\text { dissolved } \\
(\mu \mathrm{g} / \mathrm{L} \\
\text { as } \mathrm{Fe})\end{array}$ & $\begin{array}{l}\text { Lead, } \\
\text { dissolved } \\
(\mu \mathrm{g} / \mathrm{L} \\
\text { as } \mathrm{Pb})\end{array}$ & $\begin{array}{c}\text { Manganese, } \\
\text { dissolved } \\
(\mu \mathrm{g} / \mathrm{L} \\
\text { as } \mathrm{Mn})\end{array}$ & $\begin{array}{c}\text { Molybdenum, } \\
\text { dissolved } \\
(\mu \mathrm{g} / \mathrm{L} \\
\text { as Mo) }\end{array}$ & $\begin{array}{c}\text { Nickel, } \\
\text { dissolved } \\
(\mu \mathrm{g} / \mathrm{L} \\
\text { as } \mathrm{Ni})\end{array}$ & $\begin{array}{c}\text { Silver, } \\
\text { dissolved } \\
(\mu \mathrm{g} / \mathrm{L} \\
\text { as } \mathrm{Ag})\end{array}$ \\
\hline 27-1099 & $08-09-88$ & 0915 & $<10$ & 26 & $<10$ & 3 & $<10$ & $<10$ & 1.0 \\
\hline $27-1099$ & $08-09-88$ & 1030 & $<10$ & 37 & 10 & 3 & $<10$ & $<10$ & 3.0 \\
\hline $27-1099$ & $08-09-88$ & 1030 & $<10$ & 37 & 10 & 3 & $<10$ & $<10$ & 3.0 \\
\hline $27-1102$ & $08-17-88$ & 1530 & $<10$ & $<3$ & $<10$ & 1 & $<10$ & $<10$ & $<1.0$ \\
\hline $27-1105$ & $08-18-88$ & 1430 & $<10$ & $<3$ & $<10$ & $<1$ & $<10$ & $<10$ & $<1.0$ \\
\hline $27-1106$ & $08-24-88$ & 1400 & $<10$ & $<3$ & $<10$ & 14 & $<10$ & $<10$ & $<1.0$ \\
\hline $27-1107$ & $08-18-88$ & 1200 & $<10$ & $<3$ & $<10$ & $<1$ & $<10$ & $<10$ & $<1.0$ \\
\hline $27-1108$ & $08-18-88$ & 0935 & $<10$ & $<3$ & 10 & $<1$ & $<10$ & $<10$ & $<1.0$ \\
\hline $27-1118$ & $08-22-88$ & 1345 & $<10$ & 4 & $<10$ & $<1$ & $<10$ & $<10$ & $<1.0$ \\
\hline $27-1118$ & $08-22-88$ & 1345 & $<10$ & 4 & $<10$ & $<1$ & $<10$ & $<10$ & $<1.0$ \\
\hline $27-1118$ & $11-02-89$ & 1000 & $<10$ & $<3$ & $<10$ & $<1$ & $<10$ & $<10$ & $<1.0$ \\
\hline $27-1118$ & $11-02-89$ & 1000 & $<10$ & $<3$ & $<10$ & $<1$ & $<10$ & $<10$ & $<1.0$ \\
\hline 27-1119- & $08-25-88$ & 1030 & $<10$ & 3 & $<10$ & $<1$ & $<10$ & $<10$ & $<1.0$ \\
\hline $27-1122$ & $08-23-88$ & 1515 & $<10$ & 12 & 10 & 5 & $<10$ & $<10$ & 3.0 \\
\hline $27-1123$ & $10-25-89$ & 1600 & $<10$ & 10 & $<10$ & $<1$ & $<10$ & $<10$ & $<1.0$ \\
\hline $27-1125$ & $02-27-90$ & 1750 & $<10$ & 15 & $<10$ & 56 & $<10$ & $<10$ & $<1.0$ \\
\hline $27-1126$ & $05-02-90$ & 1620 & $<10$ & 22 & $<10$ & 49 & $<10$ & $<10$ & $<1.0$ \\
\hline $27-1156$ & $10-27-89$ & 1000 & $<10$ & $<3$ & $<10$ & $<1$ & $<10$ & $<10$ & $<1.0$ \\
\hline $27-1157$ & $10-24-89$ & 1300 & $<10$ & 8 & $<10$ & $<1$ & $<10$ & $<10$ & 2.0 \\
\hline $27-1158$ & $10-24-89$ & 1030 & $<10$ & 13 & $<10$ & 6 & $<10$ & $<10$ & $<1.0$ \\
\hline $27-1158$ & $10-24-89$ & 1030 & $<10$ & 13 & $<10$ & 6 & $<10$ & $<10$ & $<1.0$ \\
\hline $27-1158$ & $10-24-89$ & 1040 & $<10$ & 17 & $<10$ & 6 & $<10$ & $<10$ & $<1.0$ \\
\hline $27-1158$ & $10-2489$ & 1040 & $<10$ & 17 & $<10$ & 6 & $<10$ & $<10$ & $<1.0$ \\
\hline $27-1160$ & $09-01-89$ & 0950 & $<10$ & 17 & 20 & $<1$ & $<10$ & 10 & $<1.0$ \\
\hline $27-1160$ & $09-01-89$ & 0950 & $<10$ & 17 & 20 & $<1$ & $<10$ & 10 & $<1.0$ \\
\hline $27-1160$ & $09-01-89$ & 0955 & $<10$ & 5 & $<10$ & $<1$ & $<10$ & 10 & $<1.0$ \\
\hline $27-1160$ & 09-01-89 & 0955 & $<10$ & 5 & $<10$ & $<1$ & $<10$ & 10 & $<1.0$ \\
\hline $27-1163$ & $08-29-89$ & 1615 & $<10$ & 4 & $<10$ & $<1$ & $<10$ & $<10$ & $<1.0$ \\
\hline $27-1166$ & $11-01-89$ & 1700 & $<10$ & $<3$ & 10 & $<1$ & $<10$ & $<10$ & $<1.0$ \\
\hline $27-1168$ & $09-06-89$ & 1025 & $<10$ & 30 & $<10$ & 5 & $<10$ & $<10$ & $<1.0$ \\
\hline $27-1173$ & $09-06-89$ & 1220 & $<10$ & 6 & $<10$ & $<1$ & $<10$ & $<10$ & $<1.0$ \\
\hline $27-1175$ & $10-31-89$ & 1000 & $<10$ & 15 & 20 & 3 & $<10$ & $<10$ & $<1.0$ \\
\hline $27-1322$ & $11-03-89$ & 1030 & $<10$ & 70 & $<10$ & $<1$ & $<10$ & $<10$ & $<1.0$ \\
\hline $19-0010$ & $11-23-88$ & 1145 & 2 & 960 & $<5$ & 120 & -- & -- & -- \\
\hline $19-0010$ & $10-30-89$ & 1300 & $<10$ & 990 & $<10$ & 120 & $<10$ & $<10$ & 1.0 \\
\hline $19-0236$ & $08-26-88$ & 0845 & $<10$ & 5 & 10 & 2 & $<10$ & $<10$ & $<1.0$ \\
\hline $19-0236$ & $08-26-88$ & 0845 & $<10$ & 5 & 10 & 2 & $<10$ & $<10$ & $<1.0$ \\
\hline $19-0236$ & $08-26-88$ & 1000 & $<10$ & 4 & $<10$ & 5 & $<10$ & $<10$ & $<1.0$ \\
\hline $19-0236$ & $08-26-88$ & 1000 & $<10$ & 4 & $<10$ & 5 & $<10$ & $<10$ & $<1.0$ \\
\hline I9-0236 & $09-29-89$ & 1400 & 9 & $<3$ & 3 & 8 & - & -- & - \\
\hline $19-0236$ & 09-29-89 & 1400 & 9 & $<3$ & 3 & 8 & -- & -- & -- \\
\hline $19-0238$ & $08-25-88$ & 1430 & $<10$ & 9 & $<10$ & 1 & $<10$ & $<10$ & 2.0 \\
\hline $19-0245$ & $11-22-88$ & 1145 & 4 & 4 & $<5$ & 2 & -- & -- & -- \\
\hline 19-0245 & $10-30-89$ & 1600 & $<10$ & 8 & $<10$ & 2 & $<10$ & $<10$ & 1.0 \\
\hline $19-0253$ & $11-06-89$ & 1150 & $<10$ & $<3$ & $<10$ & $<1$ & $<10$ & $<10$ & $<1.0$ \\
\hline
\end{tabular}


Appendix 2. Results of water-quality analyses of ground-water and surface-water samples from the New Jersey Highlands study area-Continued

\begin{tabular}{|c|c|c|c|c|c|c|c|c|}
\hline $\begin{array}{c}\text { New } \\
\text { Jersey } \\
\text { well } \\
\text { number }\end{array}$ & Date & Time & $\begin{array}{c}\text { Strontium, } \\
\text { dissolved } \\
(\mu \mathrm{g} / \mathrm{L} \\
\text { as } \mathrm{Sr})\end{array}$ & $\begin{array}{c}\text { Vanadium, } \\
\text { dissolved } \\
(\mu \mathrm{g} / \mathrm{L} \\
\text { as V) }\end{array}$ & $\begin{array}{c}\text { Zinc, } \\
\text { dissolved } \\
(\mu \mathrm{g} / \mathrm{L} \\
\text { as } \mathrm{Zn})\end{array}$ & $\begin{array}{c}\text { Aluminum, } \\
\text { dissolved } \\
(\mu \mathrm{g} / \mathrm{L} \\
\text { as } \mathrm{AI})\end{array}$ & $\begin{array}{l}\text { Lithium, } \\
\text { dissolved } \\
(\mu \mathrm{g} / \mathrm{L} \\
\text { as } \mathrm{Li})\end{array}$ & $\begin{array}{c}\text { Bromide, } \\
\text { disolved } \\
(\mu \mathrm{g} / \mathrm{L} \\
\text { as } \mathrm{Br})\end{array}$ \\
\hline $27-1099$ & $08-09-88$ & 0915 & 22 & $<6$ & $<3$ & $<10$ & $<4$ & 0.012 \\
\hline $27-1099$ & $08-09-88$ & 1030 & 22 & $<6$ & 7 & $<10$ & $<4$ & .011 \\
\hline $27-1099$ & $08-09-88$ & 1030 & 22 & $<6$ & 7 & $<10$ & $<4$ & .011 \\
\hline $27-1102$ & $08-17-88$ & 1530 & 40 & $<6$ & 61 & $<10$ & $<4$ & .15 \\
\hline $27-1105$ & $08-18-88$ & 1430 & 17 & $<6$ & 3 & $<10$ & $<4$ & .015 \\
\hline $27-1106$ & $08-24-88$ & 1400 & 32 & $<6$ & 130 & $<10$ & 4 & .010 \\
\hline $27-1107$ & $08-18-88$ & 1200 & 19 & $<6$ & 6 & $<10$ & $<4$ & .014 \\
\hline $27-1108$ & $08-18-88$ & 0935 & 30 & $<6$ & 5 & $<10$ & $<4$ & .025 \\
\hline $27-1118$ & $08-22-88$ & 1345 & 49 & $<6$ & 13 & $<10$ & $<4$ & .028 \\
\hline $27-1118$ & $08-22-88$ & 1345 & 49 & $<6$ & 13 & $<10$ & $<4$ & .028 \\
\hline $27-1118$ & $11-02-89$ & 1000 & 51 & $<6$ & $<3$ & $<10$ & $<4$ & .020 \\
\hline $27-1118$ & $11-02-89$ & 1000 & 51 & $<6$ & $<3$ & $<10$ & $<4$ & .020 \\
\hline $27-1119$ & $08-25-88$ & 1030 & 31 & $<6$ & $<3$ & $<10$ & 5 & .017 \\
\hline $27-1122$ & $08-23-88$ & 1515 & 26 & $<6$ & 11 & $<10$ & 5 & .013 \\
\hline $27-1123$ & $10-25-89$ & 1600 & 32 & $<6$ & $<3$ & $<10$ & $<47$ & $<.010$ \\
\hline $27-1125$ & $02-27-90$ & 1750 & 32 & $<6$ & $<3$ & $<10$ & $<47$ & .010 \\
\hline $27-1126$ & $05-02-90$ & 1620 & 24 & $<6$ & $<3$ & 20 & $<4$ & .010 \\
\hline $27-1156$ & $10-27-89$ & 1000 & 64 & $<6$ & 62 & $<10$ & 8 & .020 \\
\hline $27-1157$ & $10-24-89$ & 1300 & 70 & $<6$ & $<3$ & $<10$ & 11 & .030 \\
\hline $27-1158$ & $10-24-89$ & 1030 & 110 & $<6$ & $<3$ & $<10$ & 11 & .030 \\
\hline $27-1158$ & $10-24-89$ & 1030 & 110 & $<6$ & $<3$ & $<10$ & 11 & .030 \\
\hline $27-1158$ & $10-24-89$ & 1040 & 110 & $<6$ & 6 & $<10$ & 12 & .030 \\
\hline $27-1158$ & $10-24-89$ & 1040 & 110 & $<6$ & 6 & $<10$ & 12 & .030 \\
\hline $27-1160$ & $09-01-89$ & 0950 & 92 & $<6$ & 14 & 10 & 9 & .040 \\
\hline $27-1160$ & $09-01-89$ & 0950 & 92 & $<6$ & 14 & 10 & 9 & .040 \\
\hline $27-1160$ & $09-01-89$ & 0955 & 91 & $<6$ & 13 & $<10$ & 9 & .040 \\
\hline $27-1160$ & $09-01-89$ & 0955 & 91 & $<6$ & 13 & $<10$ & 9 & .040 \\
\hline $27-1163$ & $08-29-89$ & 1615 & 28 & $<6$ & 3 & $<10$ & $<4$ & $<.010$ \\
\hline $27-1166$ & $11-01-89$ & 1700 & 26 & $<6$ & 4 & $<10$ & $<4$ & .030 \\
\hline $27-1168$ & $09-06-89$ & 1025 & 120 & $<6$ & 7 & 30 & $<4$ & .030 \\
\hline $27-1173$ & $09-06-89$ & 1220 & 29 & $<6$ & 6 & $<10$ & $<4$ & .020 \\
\hline $27-1175$ & $10-31-89$ & 1000 & 26 & $<6$ & $<3$ & $<10$ & $<4$ & .11 \\
\hline $27-1322$ & $11-03-89$ & 1030 & 32 & $<6$ & 6 & $<10$ & $<4$ & .010 \\
\hline $19-0010$ & $11-23-88$ & 1145 & -- & -- & 5 & $<10$ & -- & - \\
\hline $19-0010$ & $10-30-89$ & 1300 & 100 & $<6$ & $<3$ & $<10$ & 6 & .040 \\
\hline $19-0236$ & $08-26-88$ & 0845 & 27 & $<6$ & 370 & $<10$ & $<4$ & .018 \\
\hline $19-0236$ & $08-26-88$ & 0845 & 27 & $<6$ & 370 & $<10$ & $<4$ & .018 \\
\hline $19-0236$ & $08-26-88$ & 1000 & 29 & $<6$ & 740 & $<10$ & $<4$ & .019 \\
\hline $19-0236$ & $08-26-88$ & 1000 & 29 & $<6$ & 740 & $<10$ & $<4$ & .019 \\
\hline $19-0236$ & $09-29-89$ & 1400 & -- & -- & 640 & $<10$ & -- & -- \\
\hline $19-0236$ & $09-29-89$ & 1400 & -- & -- & 640 & $<10$ & -- & -- \\
\hline 19.0238 & $08-25-88$ & 1430 & 11 & $<6$ & 640 & $<10$ & $<4$ & .020 \\
\hline $19-0245$ & $11-22-88$ & 1145 & -- & -- & 270 & $<10$ & -- & -- \\
\hline $19-0245$ & $10-30-89$ & 1600 & 48 & $<6$ & 200 & $<10$ & $<4$ & .030 \\
\hline $19-0253$ & $11-06-89$ & 1150 & 39 & $<6$ & 4 & $<10$ & $<4$ & .010 \\
\hline
\end{tabular}


Appendix 2. Results of water-quality analyses of ground-water and surface-water samples from the New Jersey Highlands study area-Continued

\begin{tabular}{|c|c|c|c|c|c|c|c|}
\hline $\begin{array}{l}\text { New } \\
\text { Jersey } \\
\text { well } \\
\text { number }\end{array}$ & Date & Time & $\begin{array}{c}\text { Tritium, } \\
\text { total } \\
(\mathrm{pCi} / \mathrm{L})\end{array}$ & $\begin{array}{c}\text { Tritium, } \\
2 \text { sigma, } \\
\text { error, } \\
\text { water, whole } \\
\text { total } \\
\text { (pCi/L) }\end{array}$ & $\begin{array}{c}\mathrm{H}-2 / \mathrm{H}-1 \\
\text { stable } \\
\text { isotoope } \\
\text { ratio } \\
\text { (per mil) }\end{array}$ & $\begin{array}{c}\text { O-18/O-16 } \\
\text { stable } \\
\text { isotope } \\
\text { ratio } \\
\text { (per mil) }\end{array}$ & $\begin{array}{c}\text { Sulfate } \\
\text { water } \\
\text { dissolved } \\
\text { uncorrected } \\
(\mathrm{mg} / \mathrm{L})\end{array}$ \\
\hline $27-1099$ & 08-09-88 & 0915 & -- & -- & -- & -- & -- \\
\hline $27-1099$ & 08-09-88 & 1030 & -- & -- & -- & -- & -- \\
\hline 27-1099 & $08-09-88$ & 1030 & -- & -- & - & -- & -- \\
\hline $27-1102$ & $08-17-88$ & 1530 & -- & -- & -47.5 & -7.85 & -- \\
\hline 27-1105 & $08-18-88$ & 1430 & -- & -- & -- & -- & -- \\
\hline $27-1106$ & $08-24-88$ & 1400 & -- & -- & -- & -- & -- \\
\hline $27-1107$ & $08-18-88$ & 1200 & -- & -- & -- & -- & -- \\
\hline $27-1108$ & $08-18-88$ & 0935 & -- &.- & -- & -- & - \\
\hline $27-1118$ & $08-22-88$ & 1345 & -- & -- & -- & -- & -- \\
\hline $27-1118$ & $08-22-88$ & 1345 & -- & -- & -- & -- & -- \\
\hline $27-1118$ & $11-02-89$ & 1000 & -- & -- & -49.0 & -7.95 & $<1.0$ \\
\hline $27-1118$ & $11-02-89$ & 1000 & -- & -- & -49.0 & -7.95 & $<1.0$ \\
\hline 27-1119- & $08-25-88$ & 1030 & -- & -- & -- & -- & -- \\
\hline $27-1122$ & $08-23-88$ & 1515 & -- & -- & -- & -- & -- \\
\hline $27-1123$ & $10-25-89$ & 1600 & $<5.7$ & 3.8 & -50.5 & -8.35 & $<1.0$ \\
\hline $27-1125$ & $02-27-90$ & 1750 & $<5.7$ & 3.8 & -50.4 & -8.35 & -- \\
\hline $27-1126$ & $05-02-90$ & 1620 & 18 & 3.8 & -49.0 & -8.20 & -- \\
\hline $27-1156$ & $10-27-89$ & 1000 & -- & -- & -50.0 & -7.85 & $<1.0$ \\
\hline $27-1157$ & $10-24-89$ & 1300 & 61 & 7.0 & -47.5 & -8.05 & $<1.0$ \\
\hline $27-1158$ & $10-24-89$ & 1030 & -- & -- & -47.0 & -7.85 & $<1.0$ \\
\hline $27-1158$ & $10-24-89$ & 1030 & -- & -- & -47.0 & -7.85 & $<1.0$ \\
\hline $27-1158$ & $10-24-89$ & 1040 & -- & -- & -47.5 & -7.65 & $<1.0$ \\
\hline $27-1158$ & $10-24-89$ & 1040 & -- & -- & -47.5 & -7.65 & $<1.0$ \\
\hline $27-1160$ & 09-01-89 & 0950 & 53 & 6.4 & -48.0 & -7.90 & $<1.0$ \\
\hline $27-1160$ & 09-01-89 & 0950 & 53 & 6.4 & -48.0 & -7.90 & $<1.0$ \\
\hline $27-1160$ & 09-01-89 & 0955 & -- & -- & -49.0 & -7.85 & $<1.0$ \\
\hline $27-1160$ & 09-01-89 & 0955 & -- & -- & -49.0 & -7.85 & $<1.0$ \\
\hline $27-1163$ & 08-29-89 & 1615 & 100 & 9.0 & -49.5 & -8.20 & $<1.0$ \\
\hline $27-1166$ & $11-01-89$ & 1700 & -- & -- & -49.5 & -8.05 & $<1.0$ \\
\hline $27-1168$ & 09-06-89 & 1025 & 68 & 9.0 & -46.0 & -7.60 & $<1.0$ \\
\hline $27-1173$ & 09-06-89 & 1220 & 63 & 7.0 & -50.0 & -8.20 & $<1.0$ \\
\hline $27-1175$ & $10-31-89$ & 1000 & -- & -. & -51.5 & -8.30 & $<1.0$ \\
\hline $27-1322$ & $11-03-89$ & 1030 & - & -- & -50.5 & -8.35 & $<1.0$ \\
\hline $19-0010$ & $11-23-88$ & 1145 & -- & -- & -- & -- & -- \\
\hline $19-0010$ & $10-30-89$ & 1300 & 59 & 7.0 & -46.5 & -7.70 & $<1.0$ \\
\hline $19-0236$ & $08-26-88$ & 0845 & -- & -- & -- & -- & -- \\
\hline $19-0236$ & $08-26-88$ & 0845 & -- & -- & -- & -. & -- \\
\hline $19-0236$ & $08-26-88$ & 1000 & -- & -- & - & -- & -- \\
\hline $19-0236$ & $08-26-88$ & 1000 & -- & -- & -- & -- & -- \\
\hline $19-0236$ & $09-29-89$ & 1400 & - & -- & -- & -- & $<1.0$ \\
\hline $19-0236$ & $09-29-89$ & 1400 & -- & -- & -- & -- & $<1.0$ \\
\hline $19-0238$ & $08-25-88$ & 1430 & -- & -- & -- & -- & -- \\
\hline $19-0245$ & $11-22-88$ & 1145 & -- & -- & -- & -- & -- \\
\hline $19-0245$ & $10-30-89$ & 1600 & -- & -- & -45.0 & -7.80 & $<1.0$ \\
\hline $19-0253$ & $11-06-89$ & 1150 & 60 & 7.0 & -46.0 & -7.75 & $<1.0$ \\
\hline
\end{tabular}


Appendix 2. Results of water-quality analyses of ground-water and surface-water samples from the New Jersey Hilahlands study area-Continued

\begin{tabular}{|c|c|c|c|c|c|c|c|}
\hline $\begin{array}{c}\text { New } \\
\text { Jersey } \\
\text { well } \\
\text { number }\end{array}$ & $\begin{array}{l}\text { Aquifer } \\
\text { code }\end{array}$ & $\begin{array}{l}\text { Station } \\
\text { number }\end{array}$ & $\begin{array}{l}\text { Local } \\
\text { identifier }\end{array}$ & Date & Time & $\begin{array}{c}\text { Temper- } \\
\text { ature of } \\
\text { water } \\
(\operatorname{deg} C)\end{array}$ & $\begin{array}{c}\text { Oxygen, } \\
\text { dissolved } \\
\text { (mg/L) }\end{array}$ \\
\hline $27-1103$ & 400PCMB & 405228074401401 & ROXBURY TWP WD 10 & $08-19-88$ & 0945 & 10.5 & -- \\
\hline $27-1104$ & 400PCMB & 405228074401301 & ROXBURY TWP WD 11 & $08-19-88$ & 1030 & 11.5 & 8.2 \\
\hline $27-1120$ & 400PCMB & 404813074461701 & SMITH DOM & $08-22-88$ & 1700 & 10.5 & -- \\
\hline $27-1120$ & 400PCMB & 404813074461701 & SMITH DOM & $09-28-89$ & 1550 & 10.5 & 5.4 \\
\hline $27-1145$ & 400PCMB & 405006074402001 & ROXBURY 5 & $11-28-88$ & 1300 & 11.5 & 6.1 \\
\hline $27-1145$ & 400PCMB & 405006074402001 & ROXBURY 5 & $10-23-89$ & 1500 & 11.5 & 6.7 \\
\hline $27-1154$ & 400РCMB & 404508074480201 & GERNON DOM & 11-03-89 & 1630 & 10.5 & 10.2 \\
\hline $27-1155$ & 400РCMB & 404546074492601 & VANCE 2 SPRING & $10-24-89$ & 1600 & 10.0 & 9.0 \\
\hline $27-1159$ & 400РCMB & 404700074473801 & ALLEN 1 SPRING & $10-26-89$ & 1200 & 10.0 & 9.7 \\
\hline $27-1161$ & 400РCMB & 404751074455601 & HIGGINS DOM & $08-29-89$ & 1315 & 12.0 & .8 \\
\hline $27-1162$ & 400РCMB & 404802074450101 & GOETZ DOM & $08-31-89$ & 1835 & 11.5 & 4.5 \\
\hline $27-1171$ & 400PCMB & 405058074420701 & FLYNN DOM & $08-30-89$ & 1010 & 11.5 & 2.9 \\
\hline $27-1179$ & 400РCMB & 405237074394201 & LOZAUSKAS DOM & $08-21-89$ & 1530 & 11.0 & .1 \\
\hline
\end{tabular}

\begin{tabular}{|c|c|c|c|c|c|c|c|c|}
\hline $\begin{array}{l}\text { New } \\
\text { Jersey } \\
\text { well } \\
\text { number }\end{array}$ & Date & Time & $\begin{array}{c}\text { Specific } \\
\text { conductance } \\
\text { field } \\
(\mu \mathrm{S} / \mathrm{cm})\end{array}$ & $\begin{array}{c}\text { Specific } \\
\text { conductance } \\
\text { lab } \\
(\mu \mathrm{S} / \mathrm{cm})\end{array}$ & $\begin{array}{l}\text { Nitrogen, } \\
\text { ammonia } \\
\text { dissolved } \\
(\mathrm{mg} / \mathrm{L} \text { as } \mathrm{N})\end{array}$ & $\begin{array}{c}\text { Nitrogen, } \\
\text { nitrite } \\
\text { disolved } \\
(\mathrm{mg} / \mathrm{L} \text { as } \mathrm{N})\end{array}$ & $\begin{array}{c}\text { NItrogen, } \\
\text { ammonia }+ \\
\text { organic } \\
\text { dissolved } \\
(\mathrm{mg} / \mathrm{L} \text { as } \mathrm{N})\end{array}$ & $\begin{array}{c}\text { Nitrogen, } \\
\mathrm{NO}_{2}+\mathrm{NO}_{3} \\
\text { dissolved } \\
(\mathrm{mg} / \mathrm{L} \text { as } \mathrm{N})\end{array}$ \\
\hline $27-1103$ & $08-19-88$ & 0945 & 78 & -- & $<0.010$ & $<0.010$ & 0.20 & 0.190 \\
\hline $27-1104$ & $08-19-88$ & 1030 & 65 & -- & $<.010$ & $<.010$ & .20 & $<.100$ \\
\hline $27-1120$ & $08-22-88$ & 1700 & 121 & -- & $<.010$ & $<.010$ & .50 & 1.10 \\
\hline $27-1120$ & $09-28-89$ & 1550 & 108 & 121 & $<.010$ & $<.010$ & .70 & 1.30 \\
\hline $27-1145$ & $11-28-88$ & 1300 & 125 & 127 & $<.010$ & $<.010$ & .20 & .220 \\
\hline $27-1145$ & $10-23-89$ & 1500 & 134 & 127 & -- & -- & -- & -- \\
\hline $27-1154$ & $11-03-89$ & 1630 & 100 & 96 & $<.010$ & $<.010$ & .20 & 1.70 \\
\hline $27-1155$ & $10-24-89$ & 1600 & 156 & 153 & $<.010$ & $<.010$ & $<.20$ & .480 \\
\hline $27-1159$ & $10-26-89$ & 1200 & 69 & 57 & .010 & .010 & $<.20$ & $<.100$ \\
\hline $27-1161$ & $08-29-89$ & 1315 & 180 & 184 & .010 & $<.010$ & .30 & $<.100$ \\
\hline $27-1162$ & $08-31-89$ & 1835 & 225 & 226 & $<.010$ & $<.010$ & $<.20$ & .540 \\
\hline $27-1171$ & $08-30-89$ & 1010 & 239 & 238 & .020 & $<.010$ & $<.20$ & $<.100$ \\
\hline $27-1179$ & $08-21-89$ & 1530 & -- & 235 & .010 & .020 & .70 & $<.100$ \\
\hline
\end{tabular}

\begin{tabular}{|c|c|c|c|c|c|c|c|c|}
\hline $\begin{array}{c}\text { New } \\
\text { Jersey } \\
\text { well } \\
\text { number }\end{array}$ & Date & Time & $\begin{array}{c}\mathrm{pH} \\
\text { (standard } \\
\text { units) }\end{array}$ & $\begin{array}{c}\text { pH } \\
\text { lab } \\
\text { (standard } \\
\text { units) }\end{array}$ & $\begin{array}{c}\text { Alkalinity, } \\
\text { field } \\
(\mathrm{mg} / \mathrm{L} \text { as } \\
\left.\mathrm{CaCO}_{3}\right)\end{array}$ & $\begin{array}{c}\text { Alkalinity, } \\
\text { lab } \\
(\mathrm{mg} / \mathrm{L} \text { as } \\
\left.\mathrm{CaCO}_{3}\right)\end{array}$ & $\begin{array}{l}\text { Phosphorus } \\
\text { ortho, } \\
\text { dissolved } \\
\text { (mg/L as P) }\end{array}$ & $\begin{array}{c}\text { Carbon } \\
\text { organic, } \\
\text { dissolved } \\
(\mathrm{mg} / \mathrm{L} \text { as } \mathrm{C})\end{array}$ \\
\hline $27-1103$ & 08-19-88 & 0945 & 6.3 & -- & 41 & 34 & 0.030 & 0.5 \\
\hline $27-1104$ & $08-19-88$ & 1030 & 6.6 & -- & 25 & 22 & .020 & .5 \\
\hline $27-I 120$ & $08-22-88$ & 1700 & 6.0 & -- & 29 & 20 & .010 & .7 \\
\hline $27-1120$ & $09-28-89$ & 1550 & 5.9 & 6.1 & 19 & 20 & .020 & .5 \\
\hline 27-1145 & $11-28-88$ & 1300 & 7.3 & 7.8 & 69 & 60 & .030 & .3 \\
\hline $27-1145$ & $10-23-89$ & 1500 & 7.0 & 8.3 & 51 & 58 & -- & .5 \\
\hline $27-1154$ & $11-03-89$ & 1630 & 6.3 & 6.2 & 25 & 21 & .020 & .3 \\
\hline $27-1155$ & $10-24-89$ & 1600 & 6.2 & 6.9 & 28 & 28 & $<.010$ & $: 8$ \\
\hline $27-1159$ & $10-26-89$ & 1200 & 5.9 & 6.6 & 10 & 7.0 & $<.010$ & -- \\
\hline $27-1161$ & $08-29-89$ & 1315 & 8.0 & 8.1 & 57 & 58 & $<.010$ & .3 \\
\hline $27-1162$ & $08-31-89$ & 1835 & 8.0 & 8.0 & 96 & 98 & $<.010$ & 6.7 \\
\hline $27-1171$ & $08-30-89$ & 1010 & 7.9 & 7.8 & 57 & 57 & $<.010$ & .2 \\
\hline $27-1179$ & $08-21-89$ & 1530 & 8.6 & 8.3 & 62 & 63 & $<.010$ & .4 \\
\hline
\end{tabular}




\begin{tabular}{|c|c|c|c|c|c|c|c|c|c|}
\hline $\begin{array}{c}\text { New } \\
\text { Jersey } \\
\text { well } \\
\text { number }\end{array}$ & Date & Time & $\begin{array}{c}\text { Calcium, } \\
\text { dissolved } \\
(\mathrm{mg} / \mathrm{L} \\
\text { as } \mathrm{Ca})\end{array}$ & $\begin{array}{c}\text { Magnesium, } \\
\text { dissolved } \\
\text { (mg/L } \\
\text { as } \mathrm{Mg} \text { ) }\end{array}$ & $\begin{array}{l}\text { Sodium, } \\
\text { dissolved } \\
\text { (mg/L } \\
\text { as } \mathrm{Na})\end{array}$ & $\begin{array}{c}\text { Potassium, } \\
\text { dissolved } \\
\text { (mg/L } \\
\text { as K) }\end{array}$ & $\begin{array}{c}\text { Chloride, } \\
\text { dissolved } \\
(\mathrm{mg} / \mathrm{L} \\
\text { as } \mathrm{Cl})\end{array}$ & $\begin{array}{c}\text { Sulfate, } \\
\text { dissolved } \\
(\mathrm{mg} / \mathrm{L} \\
\left.\text { as } \mathrm{SO}_{4}\right)\end{array}$ & $\begin{array}{l}\text { Fluoride, } \\
\text { dissolved } \\
\text { (mg/L } \\
\text { as F) }\end{array}$ \\
\hline $27-1103$ & $08-19-88$ & 0945 & 6.9 & 2.7 & 5.5 & 0.50 & 2.4 & 2.4 & 0.10 \\
\hline $27-1104$ & $08-19-88$ & 1030 & 5.8 & 1.7 & 3.8 & .50 & 1.9 & 6.8 & .10 \\
\hline $27-1120$ & $08-22-88$ & 1700 & 11 & 3.5 & 4.7 & .60 & 11 & 12 & $<.10$ \\
\hline $27-1120$ & $09-28-89$ & 1550 & 11 & 3.5 & 5.0 & .60 & 12 & 12 & $<.10$ \\
\hline $27-1145$ & $11-28-88$ & 1300 & 16 & 4.0 & 6.4 & .70 & 1.1 & 3.2 & .20 \\
\hline $27-1145$ & $10-23-89$ & 1500 & 14 & 3.5 & 6.3 & .60 & 1.4 & 3.0 & .20 \\
\hline $27-1154$ & 11-03-89 & 1630 & 8.8 & 2.0 & 5.9 & .90 & 2.3 & 13 & $<.10$ \\
\hline $27-1155$ & $10-24-89$ & 1600 & 12 & 5.4 & 7.2 & .70 & 12 & 19 & .10 \\
\hline $27-1159$ & $10-26-89$ & 1200 & 3.8 & 1.8 & 3.2 & .40 & 1.8 & 13 & .10 \\
\hline $27-1161$ & $08-29-89$ & 1315 & 25 & 3.8 & 6.7 & .50 & 1.9 & 26 & .10 \\
\hline $27-1162$ & $08-31-89$ & 1835 & 22 & 14 & 3.4 & .70 & 4.8 & 13 & .10 \\
\hline $27-1171$ & $08-30-89$ & 1010 & 32 & 3.5 & 11 & .70 & 7.7 & 40 & .50 \\
\hline $27-1179$ & $08-21-89$ & 1530 & 18 & 4.1 & 23 & .70 & 24 & 12 & .30 \\
\hline $\begin{array}{c}\text { New } \\
\text { Jersey } \\
\text { well } \\
\text { number }\end{array}$ & Date & Time & $\begin{array}{c}\text { Silica, } \\
\text { dissolved } \\
(\mathrm{mg} / \mathrm{L} \\
\left.\text { as } \mathrm{SiO}_{2}\right)\end{array}$ & $\begin{array}{c}\text { Arsenic, } \\
\text { dissolved } \\
(\mu \mathrm{g} / \mathrm{L} \\
\text { as Be) }\end{array}$ & $\begin{array}{c}\text { Barium, } \\
\text { dissolved } \\
(\mu \mathrm{g} / \mathrm{L} \\
\text { as } \mathrm{Ba})\end{array}$ & $\begin{array}{c}\text { Beryllium, } \\
\text { dissolved } \\
(\mu \mathrm{g} / \mathrm{L} \\
\text { as } \mathrm{Be})\end{array}$ & $\begin{array}{c}\text { Cadmium, } \\
\text { dissolved } \\
(\mu \mathrm{g} / \mathrm{L} \\
\text { as Cd) }\end{array}$ & $\begin{array}{c}\text { Chromium, } \\
\text { dissolved } \\
(\mu \mathrm{g} / \mathrm{L} \\
\text { as } \mathrm{Cr})\end{array}$ & $\begin{array}{c}\text { Cobalt, } \\
\text { dissolved } \\
(\mu \mathrm{g} / \mathrm{L} \\
\text { as } \mathrm{Co})\end{array}$ \\
\hline $27-1103$ & $08-19-88$ & 0945 & 25 & -- & 3 & $<0.5$ & $<1.0$ & $<5$ & $<3$ \\
\hline $27-1104$ & $08-19-88$ & 1030 & 19 & -- & 3 & $<.5$ & $<1.0$ & $<5$ & $<3$ \\
\hline $27-1120$ & $08-22-88$ & 1700 & 16 & -- & 5 & $<.5$ & 1.0 & $<5$ & $<3$ \\
\hline $27-1120$ & 09-28-89 & 1550 & 16 & $<1$ & -- & -- & $<1.0$ & $<1$ & -- \\
\hline $27-1145$ & $11-28-88$ & 1300 & 27 & $<1$ & - & - & $<1.0$ & $<1$ & - \\
\hline $27-1145$ & $10-23-89$ & 1500 & 27 & $<1$ & $<2$ & $<.5$ & $<1.0$ & $<5$ & $<3$ \\
\hline $27-1154$ & $11-03-89$ & 1630 & 24 & $<1$ & $<2$ & $<.5$ & $<1.0$ & $<5$ & $<3$ \\
\hline $27-1155$ & $10-24-89$ & 1600 & 24 & $<1$ & 9 & $<.5$ & $<1.0$ & $<5$ & $<3$ \\
\hline $27-1159$ & $10-26-89$ & 1200 & 15 & $<1$ & 6 & $<.5$ & $<1.0$ & $<5$ & $<3$ \\
\hline $27-1161$ & $08-29-89$ & 1315 & 18 & $<1$ & 12 & $<.5$ & $<1.0$ & $<5$ & $<3$ \\
\hline $27-1162$ & $08-31-89$ & 1835 & 13 & $<1$ & 9 & $<.5$ & $<1.0$ & $<5$ & $<3$ \\
\hline $27-1171$ & $08-30-89$ & 1010 & 27 & $<1$ & 6 & $<.5$ & 1.0 & $<5$ & $<3$ \\
\hline $27-1179$ & $08-21-89$ & 1530 & 18 & $<1$ & $<2$ & $<.5$ & $<1.0$ & $<5$ & $<3$ \\
\hline $\begin{array}{c}\text { New } \\
\text { Jersey } \\
\text { well } \\
\text { number }\end{array}$ & Date & Time & $\begin{array}{c}\text { Copper, } \\
\text { dissolved } \\
(\mu \mathrm{g} / \mathrm{L} \\
\text { as Cu) }\end{array}$ & $\begin{array}{c}\text { Iron, } \\
\text { dissolved } \\
(\mu \mathrm{g} / \mathrm{L} \\
\text { as } \mathrm{Fe}) \\
\end{array}$ & $\begin{array}{c}\text { Lead } \\
\text { dissolved } \\
(\mu \mathrm{g} / \mathrm{L} \\
\text { as } \mathrm{Pb})\end{array}$ & $\begin{array}{c}\text { Manganese, } \\
\text { dissolved } \\
(\mu g / \mathrm{L} \\
\text { as } \mathrm{Mn})\end{array}$ & $\begin{array}{c}\text { Molybdenum, } \\
\text { dissolved } \\
(\mu \mathrm{g} / \mathrm{L} \\
\text { as Mo) }\end{array}$ & $\begin{array}{c}\text { Nickel, } \\
\text { dissolved } \\
(\mu \mathrm{g} / \mathrm{L} \\
\text { as } \mathrm{Ni})\end{array}$ & $\begin{array}{c}\text { Silver, } \\
\text { dissolved } \\
(\mu \mathrm{g} / \mathrm{L} \\
\text { as } \mathrm{Ag})\end{array}$ \\
\hline $27-1103$ & $08-19-88$ & 0945 & 10 & 10 & $<10$ & $<1$ & $<10$ & $<10$ & $<1.0$ \\
\hline $27-1104$ & $08-19-88$ & 1030 & $<10$ & 11 & $<10$ & 14 & $<10$ & $<10$ & $<1.0$ \\
\hline $27-1120$ & $08-22-88$ & 1700 & $<10$ & $<3$ & $<10$ & $<1$ & $<10$ & $<10$ & 1.0 \\
\hline $27-1120$ & $09-28-89$ & 1550 & 15 & $<3$ & 1 & $<1$ & -- & -- & -. \\
\hline $27-1145$ & $11-28-88$ & 1300 & 1 & 12 & $<5$ & 5 & -- & -- & -- \\
\hline $27-1145$ & $10-23-89$ & 1500 & $<10$ & $<3$ & $<10$ & $<1$ & $<10$ & $<10$ & 1.0 \\
\hline $27-1154$ & $11-03-89$ & 1630 & $<10$ & $<3$ & $<10$ & $<1$ & $<10$ & $<10$ & $<1.0$ \\
\hline $27-1155$ & $10-24-89$ & 1600 & $<10$ & $<3$ & $<10$ & $<1$ & $<10$ & $<10$ & $<1.0$ \\
\hline $27-1159$ & $10-26-89$ & 1200 & $<10$ & 6 & $<10$ & $<1$ & $<10$ & $<10$ & 1.0 \\
\hline $27-1161$ & $08-29-89$ & 1315 & $<10$ & 4 & $<10$ & 2 & $<10$ & $<10$ & $<1.0$ \\
\hline $27-1162$ & $08-31-89$ & 1835 & $<10$ & 5 & 10 & 3 & $<10$ & $<10$ & $<1.0$ \\
\hline $27-1171$ & $08-30-89$ & 1010 & $<10$ & 67 & 10 & 100 & $<10$ & $<10$ & 2.0 \\
\hline $27-1179$ & $08-21-89$ & 1530 & $<10$ & 7 & $<10$ & 12 & $<10$ & $<10$ & $<1.0$ \\
\hline
\end{tabular}


Appendix 2. Results of water-quality analyses of ground-water and surface-water samples from the New Jersey Highlands study area-Continued

\begin{tabular}{|c|c|c|c|c|c|c|c|c|}
\hline $\begin{array}{c}\text { New } \\
\text { Jersey } \\
\text { well } \\
\text { number }\end{array}$ & Date & Time & $\begin{array}{c}\text { Strontium, } \\
\text { dissolved } \\
(\mu \mathrm{g} / \mathrm{L} \\
\text { as } \mathrm{Sr})\end{array}$ & $\begin{array}{c}\text { Vanadium, } \\
\text { dissolved } \\
(\mu \mathrm{g} / \mathrm{L} \\
\text { as V) }\end{array}$ & $\begin{array}{c}\text { Zinc, } \\
\text { dissolved } \\
(\mu \mathrm{g} / \mathrm{L} \\
\text { as } \mathrm{Zn})\end{array}$ & $\begin{array}{l}\begin{array}{c}\text { Aluminum, } \\
\text { dissolved } \\
(\mu \mathrm{g} / \mathrm{L}\end{array} \\
\text { as } \mathrm{Al})\end{array}$ & $\begin{array}{l}\text { Lithium, } \\
\text { dissolved } \\
(\mu \mathrm{g} / \mathrm{L} \\
\text { as Li) }\end{array}$ & $\begin{array}{c}\text { Bromide, } \\
\text { dissolved } \\
(\mu \mathrm{g} / \mathrm{L} \\
\text { as } \mathrm{Br})\end{array}$ \\
\hline $27-1103$ & $08-19-88$ & 0945 & 35 & $<6$ & 200 & $<10$ & $<4$ & .023 \\
\hline $27-1104$ & $08-19-88$ & 1030 & 23 & $<6$ & 1,600 & 30 & $<4$ & .016 \\
\hline $27-1120$ & $08-22-88$ & 1700 & 33 & $<6$ & $<3$ & $<10$ & $<4$ & .022 \\
\hline $27-1120$ & $09-28-89$ & 1550 & - & -- & 7 & $<10$ & -. & -. \\
\hline $27-I 145$ & $11-28-88$ & 1300 & - & - & 7 & $<10$ & -- & -- \\
\hline $27-1145$ & $10-23-89$ & 1500 & 28 & $<6$ & 8 & $<10$ & $<4$ & $<.010$ \\
\hline $27-1154$ & 11-03-89 & 1630 & 70 & $<6$ & $<3$ & $<10$ & $<4$ & .010 \\
\hline $27-1155$ & $10-24-89$ & 1600 & 46 & $<6$ & $<3$ & $<10$ & $<4$ & .020 \\
\hline $27-1159$ & $10-26-89$ & 1200 & 21 & $<6$ & 3 & $<10$ & $<4$ & .010 \\
\hline $27-1161$ & $08-29-89$ & 1315 & 72 & $<6$ & $<3$ & 20 & 5 & $<.010$ \\
\hline $27-1162$ & $08-31-89$ & 1835 & 29 & $<6$ & 7 & $<10$ & $<4$ & .020 \\
\hline $27-1171$ & $08-30-89$ & 1010 & 110 & $<6$ & 4 & 20 & 6 & .010 \\
\hline $27-1179$ & $08-21-89$ & 1530 & 50 & $<6$ & 4 & $<10$ & $<4$ & .020 \\
\hline $\begin{array}{c}\text { New } \\
\text { Jersey } \\
\text { well } \\
\text { number }\end{array}$ & Date & Time & $\begin{array}{l}\text { Tritium, } \\
\text { total } \\
(\mathrm{pCi} / \mathrm{L})\end{array}$ & $\begin{array}{c}\text { Tritium, } \\
2 \text { sigma, } \\
\text { error, } \\
\text { water, whole } \\
\text { total } \\
(\mathrm{pCi} / \mathrm{L})\end{array}$ & $\begin{array}{l}\text { H-2/H-1 } \\
\text { stable } \\
\text { isotope } \\
\text { ratio } \\
\text { (per mil) }\end{array}$ & $\begin{array}{c}\text { O- } 18 / 0-16 \\
\text { stable } \\
\text { isotope } \\
\text { ratio } \\
\text { (per mil) }\end{array}$ & \multicolumn{2}{|c|}{$\begin{array}{c}\text { Sulfate } \\
\text { water } \\
\text { dissolved } \\
\text { uncorrected } \\
(\mathrm{mg} / \mathrm{L})\end{array}$} \\
\hline $27-1103$ & $08-19-88$ & 0945 & - & $-\infty$ & - & - & \multicolumn{2}{|c|}{-- } \\
\hline $27-1104$ & $08-19-88$ & 1030 & - & - & $\cdots$ & - & \multicolumn{2}{|c|}{--} \\
\hline $27-1120$ & $08-22-88$ & 1700 & -- & -- & -- & -- & \multicolumn{2}{|c|}{-- } \\
\hline $27-1120$ & $09-28-89$ & 1550 & - & $\cdots$ & - & -- & \multicolumn{2}{|c|}{$<1.0$} \\
\hline $27-1145$ & $11-28-88$ & 1300 & -- & -- & -- & -- & \multicolumn{2}{|c|}{--} \\
\hline $27-1145$ & $10-23-89$ & 1500 & - & -- & -51.5 & -8.35 & \multicolumn{2}{|c|}{$<1.0$} \\
\hline $27-1154$ & $11-03-89$ & 1630 & - & -- & -46.5 & -7.90 & \multicolumn{2}{|c|}{$<1.0$} \\
\hline $27-1155$ & $10-24-89$ & 1600 & 64 & -- & -44.5 & -7.70 & \multicolumn{2}{|c|}{$<1.0$} \\
\hline $27-1159$ & $10-26-89$ & 1200 & -- & -- & -43.0 & -7.05 & \multicolumn{2}{|c|}{$<1.0$} \\
\hline $27-1161$ & $08-29-89$ & 1315 & 57 & 7.7 & -46.0 & -7.95 & \multicolumn{2}{|c|}{$<1.0$} \\
\hline $27-1162$ & $08-31-89$ & 1835 & -- & -. & -51.0 & -8.15 & \multicolumn{2}{|c|}{$<1.0$} \\
\hline $27-1171$ & $08-30-89$ & 1010 & 35 & 5.8 & -51.5 & -8.45 & \multicolumn{2}{|c|}{$<1.0$} \\
\hline $27-1179$ & $08-21-89$ & 1530 & 22 & 3.8 & -52.5 & -8.40 & \multicolumn{2}{|c|}{$<1.0$} \\
\hline
\end{tabular}

\begin{tabular}{|c|c|c|c|c|c|c|c|}
\hline $\begin{array}{l}\text { Station } \\
\text { number }\end{array}$ & $\begin{array}{l}\text { Local } \\
\text { identifier }\end{array}$ & Date & Time & $\begin{array}{c}\text { Temper- } \\
\text { ature } \\
\text { water } \\
(\operatorname{deg} C)\end{array}$ & $\begin{array}{c}\text { Oxygen, } \\
\text { dissolved } \\
(\mathrm{mg} / \mathrm{L})\end{array}$ & $\begin{array}{c}\text { Specific } \\
\text { conductance } \\
\text { field } \\
(\mu \mathrm{S} / \mathrm{cm})\end{array}$ & $\begin{array}{c}\text { Specific } \\
\text { conductance } \\
\text { lab } \\
(\mu \mathrm{S} / \mathrm{cm})\end{array}$ \\
\hline 01396147 & DRAKES BROOK NEAR FLANDERS & $08-24-89$ & 1445 & 20.5 & 8.4 & 442 & 334 \\
\hline 01396 I 53 & DRAKES BROOK TRIB 2 NEAR F & $08-24-89$ & 1215 & 17.5 & 9.0 & 200 & 204 \\
\hline 01396160 & DRAKES BROOK AT REGER ROAD & $08-24-89$ & 1700 & 22.5 & 8.2 & 319 & 443 \\
\hline 01396185 & SB RARITAN RIVER AT FOUR B & $08-24-89$ & 1000 & 18.0 & 8.9 & 250 & 251 \\
\hline 01396220 & STONY BROOK AT NAUGHRIGHT, & $10-24-63$ & -- & 13.0 & $\cdots$ & 90 & -- \\
\hline 01396220 & STONY BROOK AT NAUGHRIGHT, & $08-23-89$ & 1330 & 19.5 & 8.7 & 140 & 146 \\
\hline 01396230 & SB RARITAN RIVER NEAR LONG & $08-23-89$ & 1545 & 21.5 & 9.5 & 233 & 238 \\
\hline
\end{tabular}




\begin{tabular}{|c|c|c|c|c|c|c|c|c|c|}
\hline $\begin{array}{c}\text { Station } \\
\text { number }\end{array}$ & Date & Time & $\begin{array}{l}\text { Nitrogen, } \\
\text { ammonia } \\
\text { dissolved } \\
(\mathrm{mg} / \mathrm{L} \text { as } \mathrm{N})\end{array}$ & $\begin{array}{c}\text { Nitrogen, } \\
\text { nitrite } \\
\text { dissolved } \\
(\mathrm{mg} / \mathrm{L} \text { as } \mathrm{N})\end{array}$ & $\begin{array}{r}\text { Nitrog } \\
\text { ammon } \\
\text { organ } \\
\text { dissolv } \\
(\mathrm{mg} / \mathrm{L} \\
\mathrm{N})\end{array}$ & $\begin{array}{ll}\text { gen, } & \\
\text { nia }+ & \mathrm{Nit} \\
\text { nic } & \mathrm{NO}_{2} \\
\text { lved } & \text { diss } \\
\text { L as } & \text { (m } \\
& \end{array}$ & $\begin{array}{l}\text { rogen, } \\
+\mathrm{NO}_{3} \\
\text { solved } \\
\mathrm{g} / \mathrm{L} \text { as } \\
\mathrm{N} \text { ) }\end{array}$ & $\begin{array}{c}\mathrm{pH} \\
\text { (standard } \\
\text { units) }\end{array}$ & $\begin{array}{c}\mathrm{pH} \\
\text { lab } \\
\text { (standard } \\
\text { units) }\end{array}$ \\
\hline 01396147 & $08-24-89$ & 1445 & 0.010 & $<0.010$ & 0.50 & & 1.30 & 8.2 & 8.0 \\
\hline 01396153 & $08-24-89$ & 1215 & $<.010$ & $<.010$ & .50 & 30 & 2.00 & 7.8 & 7.9 \\
\hline 01396160 & $08-24-89$ & 1700 & .020 & .010 & .60 & 50 & 1.40 & 8.4 & 8.0 \\
\hline 01396185 & $08-24-89$ & 1000 & .030 & .010 & .30 & 30 & 1.40 & 8.0 & 7.9 \\
\hline 01396220 & $10-24-63$ & -- & -- & -- & -- & - & & 6.9 & -- \\
\hline 01396220 & $08-23-89$ & 1330 & .010 & $<.010$ & .40 & 10 & .880 & 7.9 & 7.9 \\
\hline 01396230 & 08-23-89 & 1545 & .040 & .030 & .50 & & 1.50 & 8.5 & 8.3 \\
\hline $\begin{array}{c}\text { Station } \\
\text { number }\end{array}$ & Date & Time & $\begin{array}{c}\text { Alkalinity, } \\
\text { field } \\
(\mathrm{mg} / \mathrm{L} \text { as } \\
\left.\mathrm{CaCO}_{3}\right)\end{array}$ & $\begin{array}{c}\text { Alkalinity, } \\
\text { lab } \\
(\mathrm{mg} / \mathrm{L} \text { as } \\
\left.\mathrm{CaCO}_{3}\right)\end{array}$ & $\begin{array}{r}\text { Phosp } \\
\text { orth } \\
\text { disso } \\
\text { (mg/L }\end{array}$ & $\begin{array}{lr}\text { ohorus } & \text { C } \\
\text { tho, } & \text { or } \\
\text { olved } & \text { dis } \\
\text { Las P) } & \text { (mg }\end{array}$ & $\begin{array}{l}\text { Carbon } \\
\text { rganic, } \\
\text { (ssolved } \\
\text { g/L as C) }\end{array}$ & $\begin{array}{c}\text { Calcium, } \\
\text { dissolved } \\
(\mathrm{mg} / \mathrm{L} \\
\text { as Ca) }\end{array}$ & $\begin{array}{c}\text { Magnesium, } \\
\text { dissolved } \\
(\mathrm{mg} / \mathrm{L} \\
\text { as } \mathrm{Mg})\end{array}$ \\
\hline 01396147 & $08-24-89$ & 1445 & 89 & 68 & & .030 & 3.2 & 26 & 11 \\
\hline 01396153 & $08-24-89$ & 1215 & 27 & 28 & & .110 & 1.7 & 13 & 4.8 \\
\hline 01396160 & $08-24-89$ & 1700 & 77 & 95 & & 010 & 3.0 & 36 & 16 \\
\hline 01396185 & $08-24-89$ & 1000 & 57 & 57 & & .050 & 2.7 & 19 & 8.6 \\
\hline 01396220 & $10-24-63$ & -. & 34 & -- & -- & & -- & -- & -- \\
\hline 01396220 & 08-23-89 & 1330 & 33 & 56 & & .020 & 1.8 & 13 & 4.5 \\
\hline 01396230 & $08-23-89$ & 1545 & 64 & 66 & & .120 & 2.6 & 20 & 9.4 \\
\hline $\begin{array}{l}\text { Station } \\
\text { number }\end{array}$ & Date & Time & $\begin{array}{c}\text { Sodium, } \\
\text { dissolved } \\
(\mathrm{mg} / \mathrm{L} \\
\text { as } \mathrm{Na})\end{array}$ & $\begin{array}{c}\text { Potassium, } \\
\text { dissolved } \\
(\mathrm{mg} / \mathrm{L} \\
\text { as K })\end{array}$ & $\begin{array}{c}\text { Chloride, } \\
\text { dissolved } \\
(\mathrm{mg} / \mathrm{L} \\
\text { as } \mathrm{Cl}) \\
\end{array}$ & $\begin{array}{c}\text { Sulfate, } \\
\text { dissolved } \\
(\mathrm{mg} / \mathrm{L} \\
\left.\text { as } \mathrm{So}_{4}\right)\end{array}$ & $\begin{array}{c}\text { Fluoride, } \\
\text { dissolved } \\
(\mathrm{mg} / \mathrm{L} \\
\text { as } \mathrm{F}) \\
\end{array}$ & $\begin{array}{c}\text { Silica, } \\
\text { dissolved } \\
(\mathrm{mg} / \mathrm{L} \\
\left.\text { as } \mathrm{SiO}_{2}\right)\end{array}$ & $\begin{array}{c}\text { Arsenic, } \\
\text { dissolved } \\
(\mu \mathrm{g} / \mathrm{L} \\
\text { as As) }\end{array}$ \\
\hline 01396147 & $08-24-89$ & 1445 & 20 & 1.9 & 45 & 15 & 0.10 & 13 & $<1$ \\
\hline 01396153 & $08-24-89$ & 1215 & 16 & 1.4 & 29 & 10 & .10 & 16 & $<1$ \\
\hline 01396160 & $08-24-89$ & 1700 & 26 & 1.9 & 63 & 20 & .10 & 15 & $<1$ \\
\hline 01396185 & $08-24-89$ & 1000 & 13 & 1.4 & 26 & 11 & .10 & 13 & 1 \\
\hline 01396220 & $10-24-63$ & -- & -- & -- & 3.0 & 6.4 & -- & -- & -- \\
\hline 01396220 & $08-23-89$ & 1330 & 6.7 & 1.2 & 11 & 10 & .10 & 18 & $<1$ \\
\hline 01396230 & $08-23-89$ & 1545 & 11 & 1.4 & 21 & 9.0 & .10 & 15 & 1 \\
\hline $\begin{array}{c}\text { Station } \\
\text { number }\end{array}$ & Date & Time & $\begin{array}{c}\text { Barium. } \\
\text { dissolved } \\
(\mu \mathrm{g} / \mathrm{L} \\
\text { as } \mathrm{Ba})\end{array}$ & $\begin{array}{c}\text { Beryllium. Cac } \\
\text { dissolved } \\
(\mu \mathrm{g} / \mathrm{L} \\
\text { as } \mathrm{Be})\end{array}$ & $\begin{array}{l}\text { admium, C } \\
\text { issolved } \\
(\mu \mathrm{g} / \mathrm{L} \\
\text { as Cd })\end{array}$ & $\begin{array}{l}\text { Chromium. } \\
\text { dissolved } \\
(\mu \mathrm{g} / \mathrm{L} \\
\text { as } \mathrm{Cr})\end{array}$ & $\begin{array}{c}\text { Cobalt. } \\
\text { dissolved } \\
(\mu \mathrm{g} / \mathrm{L} \\
\text { as Co) }\end{array}$ & $\begin{array}{c}\text { Copper, } \\
\text { dissolved } \\
(\mu \mathrm{g} / \mathrm{L} \\
\text { as } \mathrm{Cu})\end{array}$ & $\begin{array}{c}\text { Iron, } \\
\text { dissolved } \\
(\mu \mathrm{g} / \mathrm{L} \\
\text { as Fe })\end{array}$ \\
\hline 01396147 & $08-24-89$ & 1445 & 40 & $<0.5$ & $<1.0$ & $<5$ & $<3$ & $<10$ & 47 \\
\hline 01396153 & $08-24-89$ & 1215 & 27 & $<.5$ & $<1.0$ & $<5$ & $<3$ & $<10$ & 17 \\
\hline 01396160 & $08-24-89$ & 1700 & 27 & $<.5$ & $<1.0$ & $<5$ & $<3$ & $<10$ & 55 \\
\hline 01396185 & $08-24-89$ & 1000 & 35 & $<.5$ & $<1.0$ & $<5$ & $<3$ & $<10$ & 68 \\
\hline 01396220 & $10-24-63$ & $-\cdot$ & -- & -- & -- & -- & - & $\cdots$ & -- \\
\hline 01396220 & 08-23-89 & 1330 & 39 & $<.5$ & $<1.0$ & $<5$ & $<3$ & $<10$ & 19 \\
\hline 01396230 & $08-23-89$ & 1545 & 34 & $<.5$ & $<1.0$ & $<5$ & $<3$ & $<10$ & 50 \\
\hline
\end{tabular}


Appendix 2. Results of water-quality analyses of ground-water and surface-water samples from the New Jersey Highlands study area-Continued

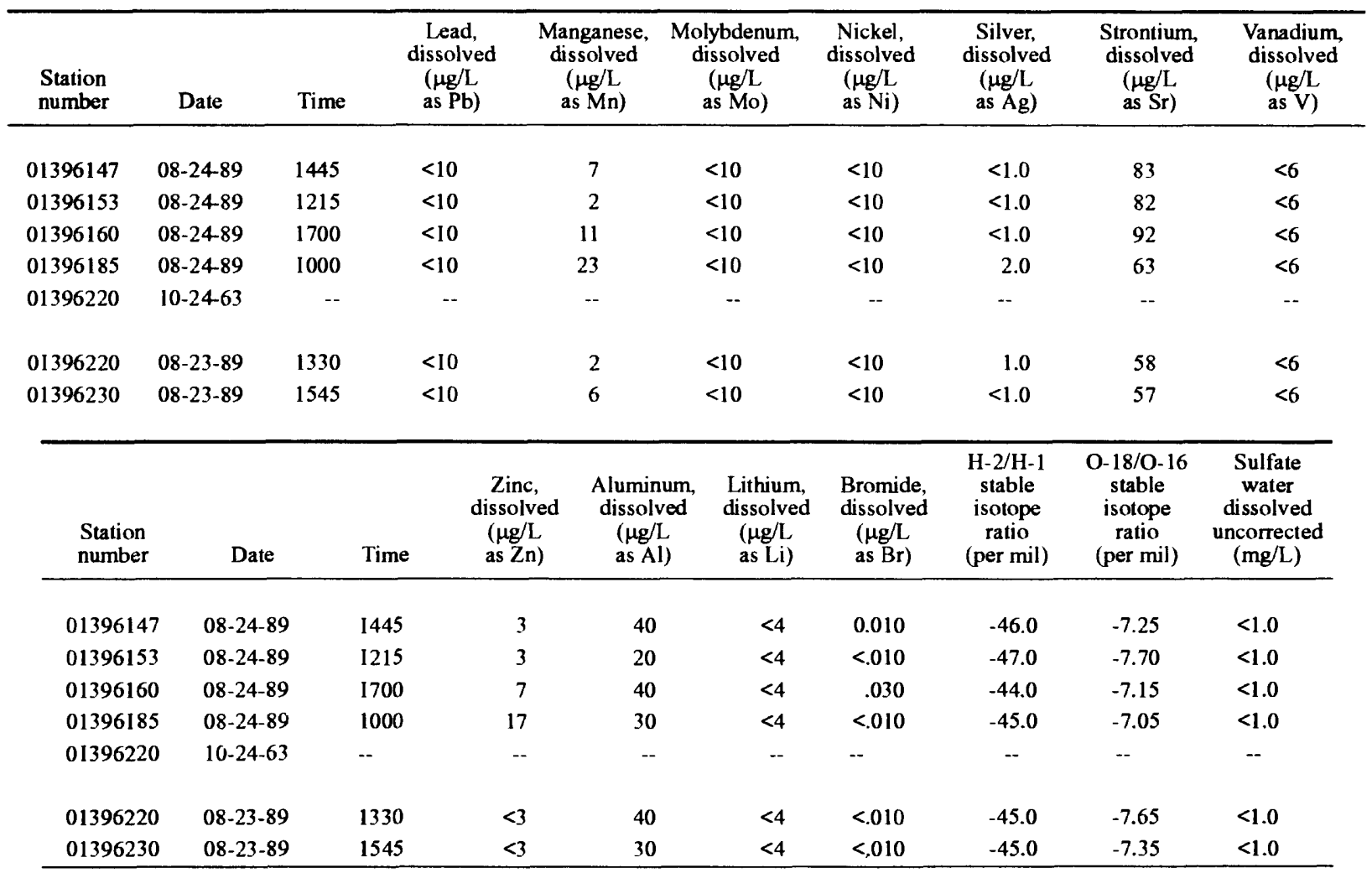


Appendix 3. Ratios of strontium-87 to strontium-86 in ground-water and surface-water samples from the New Jersey Highlands study area

${ }^{[87} \mathrm{Sr}$, strontium-87; ${ }^{86} \mathrm{Sr}$, strontium-86; --, sample not analyzed]

\begin{tabular}{|c|c|c|}
\hline $\begin{array}{c}\text { New } \\
\text { Jersey } \\
\text { well } \\
\text { number }\end{array}$ & Local identifier & ${ }^{87} \mathrm{Sr} /{ }^{86} \mathrm{Sr}$ \\
\hline
\end{tabular}

Valley-fill aquifers

$\begin{array}{llr}19-0255 & \text { MERRILL DOM } & 0.71392 \\ 27-1089 & \text { CHUDOBA 1 } & .71756 \\ 27-1091 & \text { WIEN LABORATORIES I } & .70977 \\ 27-1094 & \text { MORRIS CO MUA B4 LOWER } & .71389 \\ 27-1095 & \text { MORRIS CO MUA B4 UPPER } & .71174 \\ & & \\ 27-1096 & \text { MORRIS CO MUA B6 LOWER } & .71106 \\ 27-1097 & \text { MORRIS CO MUA B6 UPPER } & .71250 \\ 27-1098 & \text { BOHS 1 } & .70957 \\ 27-1100 & \text { ROXBURY WATER CO 1 } & .71063 \\ 27-1101 & \text { GRABER 1 } & .71037 \\ & & .71220 \\ 27-1121 & \text { BEAM 1 } & .71218 \\ 27-1124 & \text { KENVIL NEWCRETE USGS 2 } & .71102 \\ 27-1165 & \text { EBERBACH 1 } & .71011 \\ 27-1167 & \text { REDER DOM } & .71079 \\ 27-1169 & \text { WEB DYNAMICS IND } & .71090 \\ & & \end{array}$

Carbonate-rock aquifer

$\begin{array}{llc}19-0237 & \text { KENNEDY 1 } & .71383 \\ 19-0252 & \text { BAUMGARTNER DOM REPLACE } & .70965 \\ 19-0254 & \text { JONES DOM } & .71993 \\ 19-0256 & \text { BARKMAN RT 513 STANDBY } & .71270 \\ 19-0284 & \text { MARTINO 1 } & .71162 \\ & & \\ 27-1090 & \text { MORRIS CO MUA 5 } & .71597 \\ 27-1092 & \text { MT OLIVE TWP FLANDERS2 } & .71245, .71239, .71248^{*} \\ 27-1093 & \text { MT OLIVE TWP FLANDERS3 } & .71115 \\ 27-1099 & \text { JAMES SMITH 1 } & .71121, .71117^{* *} \\ 27-1102 & \text { BAIETTO 1 } & .71155 \\ & & \\ 27-1105 & \text { MCCORMACK 1 } & 0.71122 \\ 27-1106 & \text { W MORRIS CENTRAL HS 1 } & .71151 \\ 27-1107 & \text { PACZKOWSKI 1 } & .71030 \\ 27-1108 & \text { NAUGHRIGHT 1 } & .71147 \\ 27-1118 & \text { LYNCH 1 } & .71120, .71116^{* * *} \\ & & .71336 \\ 27-1119- & \text { LONG VALLEY PRESB CH } & .71197 \\ 27-1122 & \text { VANCE 1 } & .71278 \\ 27-1123 & \text { KENVIL NEWCRETE USGS 1 } & .71103 \\ 27-1156 & \text { ODOWD DOM } & .71089 \\ 27-1157 & \text { RYAN DOM WELL } & \end{array}$




\begin{tabular}{|c|c|c|}
\hline $\begin{array}{c}\text { New } \\
\text { Jersey } \\
\text { well } \\
\text { number }\end{array}$ & Local identıfier & ${ }^{87} \mathrm{Sr}_{\mathbf{r}}{ }^{86} \mathrm{Sr}$ \\
\hline \multicolumn{3}{|c|}{ Carbonate-rock aquifer-Continued } \\
\hline $27-1158$ & RYAN 2 SPRING & $.71103, .71105^{* *}$ \\
\hline $27-1160$ & WELSH FARMS I & $.71063, .71072^{* *}$ \\
\hline $27-1163$ & COLLING DOM & .71250 \\
\hline $27-1166$ & ZAIKOWSKI DOM & .71147 \\
\hline $27-1168$ & MARVELAND FARMS & .71039 \\
\hline $27-1173$ & RWC PW7-PLEASANT VILL I & .71155 \\
\hline \multicolumn{3}{|c|}{ Precambrian gneiss rock } \\
\hline $19-0010$ & SPRING VALLEY 1 & .72065 \\
\hline $19-0236$ & MILLER I & $.71522, .71522^{* *}$ \\
\hline $19-0238$ & SEICKEL I & .72716 \\
\hline $19-0245$ & CALIFON 2 & .71787 \\
\hline $19-0253$ & BATSON 234 RT 513 & .70881 \\
\hline $27-1103$ & ROXBURY TWP WD 10 & .70906 \\
\hline $27-1104$ & ROXBURY TWP WD II & .70859 \\
\hline $27-1120$ & SMITH DOM & .71006 \\
\hline $27-1145$ & ROXBURY 5 & .71027 \\
\hline 27.1154 & GERNON DOM & .71628 \\
\hline $27-1155$ & VANCE 2 SPRING & 0.70981 \\
\hline $27-1159$ & ALLEN I SPRING & .71158 \\
\hline 27.1161 & HIGGINS DOM & .71659 \\
\hline $27-1162$ & GOETZ DOM & .71218 \\
\hline $27-1171$ & FLYNN DOM & .71813 \\
\hline 27.1179 & LOZAUSKAS DOM & .70940 \\
\hline$\frac{\text { Station }}{\text { number }}$ & \multicolumn{2}{|l|}{ Surface water } \\
\hline 01396220 & STONY BROOK AT NAUGHRIGHT & 0.71212 \\
\hline 01396230 & SB RARITAN RIVER NEAR LONG VALLEY & .71127 \\
\hline 01396185 & SB RARITAN RIVER AT FOUR BRIDGES & .71108 \\
\hline 01396153 & DRAKES BROOK TRIB 2 NEAR FLANDERS & .71092 \\
\hline 01396147 & DRAKES BROOK NEAR FLANDERS & .71045 \\
\hline 01396160 & DRAKES BROOK AT REGER ROAD & .71036 \\
\hline
\end{tabular}

*Aliquots of same sample.

**Duplicate samples.

***Samples from 1988, 1989. 
